\author{
Universidade de São Paulo \\ Faculdade de Filosofia, Letras e Ciências Humanas \\ Departamento de Letras Orientais \\ Programa de Pós-Graduação em Língua, Literatura e Cultura Árabe
}

\title{
O discurso sobre o muçulmano na imprensa brasileira: o caso da revista Veja
}

\section{Rodrigo Simon de Moraes}

Dissertação apresentada ao Programa de Pós-Graduação em Língua, Literatura e Cultura Árabe do Departamento de Letras Orientais da Faculdade de Filosofia, Letras e Ciências Humanas da Universidade de São Paulo para obtenção do título de mestre em Língua, Literatura e Cultura Árabe.

Orientador: Prof. Dr. Paulo Daniel Elias Farah

São Paulo 
A eles, que já se foram, mas deixam neste trabalho uma marca indelével. Sem o exemplo do meu avô José Simon e a ajuda do meu tio Paulo Roberto Simon, não chegaria até aqui. Aos dois, dedico este trabalho. 


\section{Agradecimentos}

A etimologia indica entre as origens formadoras do substantivo orientador "o instrumento utilizado para determinar o Oriente, em relação a qualquer ponto", além da acepção mais usual, como adjetivo, "quem ou o que orienta". O trabalho do Prof. Dr. Paulo Daniel Elias Farah teve para mim ambos os significados. Com seu brilhantismo acadêmico, guiou-me rumo ao Oriente; não ao Oriente geográfico, mas ao "nosso Oriente tal como foi orientalizado". Com sua postura intelectual, conduziu-me pela estrada da pesquisa.

À FFLCH, cuja grandiosidade histórica me inspirou em cada dia dessa jornada. A honra de pertencer ao quadro de estudantes que a partir desses prédios escreveram parcela significativa da história intelectual do Brasil é algo que não pode ser descrito em toda sua imensidão, apenas vivenciado orgulhosamente.

À professora Rosana Soares Lima, por me preparar e desafiar a ir além na busca por respostas.

Aos professores que a despeito da distância foram generosos e comigo compartilharam seus conhecimentos: Viviane de Melo Resende, Zilda Gaspar Oliveira de Aquino, Carmen Rosa Caldas-Coulthard, Lynn Mario Trindade Menezes de Souza e Ivan Prado Teixeira.

E especialmente à minha mãe, Maria Helena Simon, a quem meus agradecimentos jamais serão suficientes para expressar o quanto sou grato. 
"Uma das tarefas do intelectual reside no esforço em derrubar os estereótipos e as categorias redutoras que tanto limitam o pensamento humano e a comunicação."

Edward W. Said 


\section{Resumo}

Este trabalho investiga o discurso elaborado pela revista Veja sobre os países de maioria muçulmana e os seguidores da religião islâmica. Tendo como suporte teórico as reflexões sobre o Orientalismo, de Edward W. Said, e a Teoria Social do Discurso, abordagem da Análise de Discurso Crítica (ADC), de Norman Fairclough, aplicamos uma combinação de análises qualitativa e quantitativa em um corpus composto por unidades textuais publicadas em três diferentes períodos, tendo como ponto referencial o 11 de setembro de 2001, sendo que os textos são observados não apenas como evento linguístico, mas como práticas sociais constitutivas e constituídas pelos sistemas de crença. Através da identificação, compreensão e determinação das operações que organizam e constroem os enunciados e seus significados, demonstramos que a publicação brasileira sustenta o discurso orientalista através da reprodução do discurso hegemônico norte-americano, o que carrega um caráter disciplinador que age pela legitimação e naturalização das posições que interessam aos Estados Unidos. O resultado adjacente é a construção e manutenção de uma identidade negativa dos que professam sua fé na religão islâmica. 


\section{Abstract}

This work investigates the discourse elaborated by Veja magazine about countries of Muslim majority and the followers of the Islamic religion. Having reflections about Orientalism by Edward W. Said and the Social Theory of Discourse, the Critical Discourse Analysis (CDA) approach of Norman Fairclough as theoretical support, we apply a combination of qualitative and quantitative analysis in a corpus composed of textual units during three different periods, with September 11 as a point of reference. The texts are observed not only as a linguistic event, but as constitutive social practices that are constituted by the systems of belief. By means of the identification, comprehension and determination of the operations that organize and construct the statements and their meanings, we demonstrate that the Brazilian publication sustains the orientalist discourse by means of the reproduction of the hegemonic NorthAmerican discourse that carries with it a disciplinary character that works in favor of the legitimacy and naturalization of the positions of United States interest. The underlying result is the construction and maintenance of a negative identity of those who profess their faith in the Islamic religion. 


\section{Sumário}

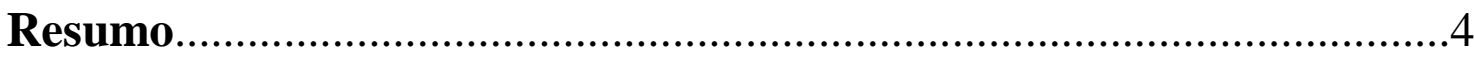

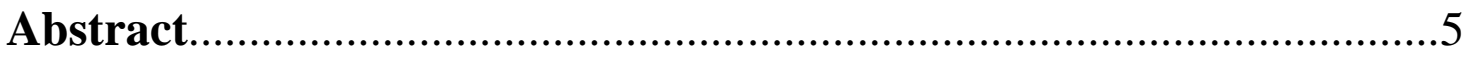

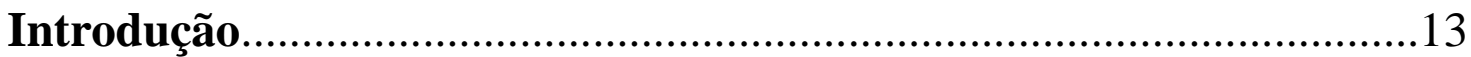

\section{Capítulo I - Orientalismo}

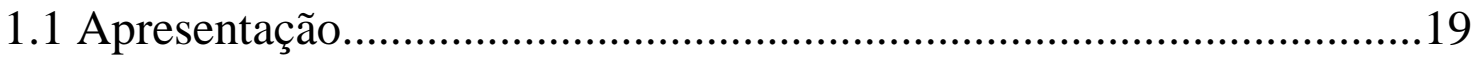

1.1.1 - Preconceito e estereótipo.........................................................25

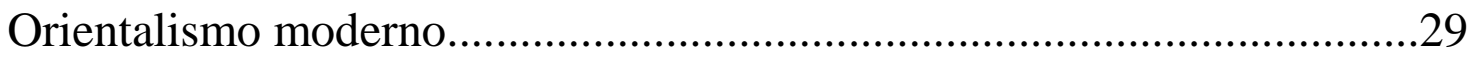

1.2.1 - Choque de civilizações........................................................29

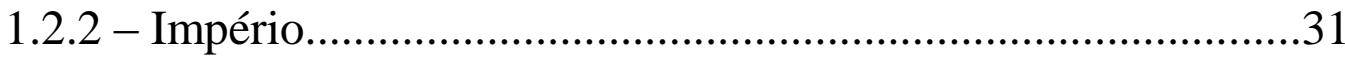

1.2.3 - Orientalismo na imprensa.....................................................33

1.2.4 - Agências de notícias.............................................................36

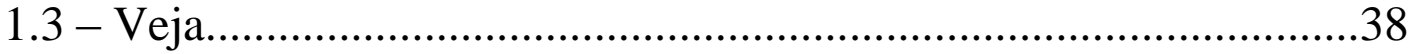

\section{Capítulo II - Análise de Discurso Crítica e Teoria Social do Discurso}

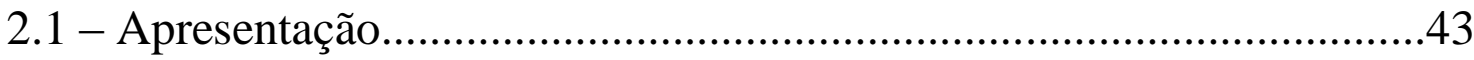

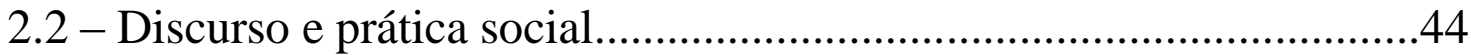

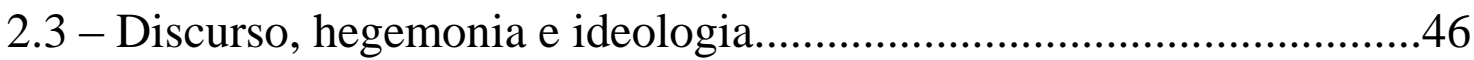

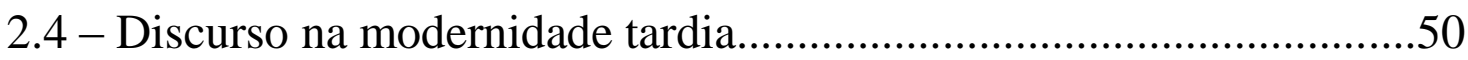

2.5 - Influências sobre a Análise do Discurso Crítica...................................53

2.6 - Paradigma funcionalista e Linguística Sistêmica Funcional..............56

Capítulo III - Análise qualitativa: - O discurso jornalístico como ação e identificação

3.1 - Categorias de análise.........................................59

3.1 .1 - Intertextualidade.....................................59

3.1.2 - Avaliações......................................................61

3.2 - Análise corpus pré-11 de setembro...............................................62

3.3 - Análise corpus imediatamente pós-11 de setembro.............................87 
3.4 - Análise corpus pós-11 de setembro. 146

\section{Capítulo IV - Análise quantitativa}

4.1 - Definição e coleta do corpus.

4.2 - Dados das publicações pré-11 de setembro - Edições 1 666, 1 667, 1 668 e 1669.

4.3 - Dados das publicações imediatamente após 11 de setembro - Edições $1718,1719,1720$ e 1721 178

4.4 - Dados das publicações um ano após 11 de setembro - Edições 1 768, $1769,1770,1771$ 179

4.5 - Comparação dos dados das publicações em três períodos 180

4.6 - Quem fala em Veja. 182

4.7 - Dados complementares.... 184

4.7.1 - Fontes utilizadas por Veja nas publicações pré-11 de setembro -Edições 1 666, 1 667, 1 668, 1669. 185

4.7.2 - Fontes utilizadas por Veja nas publicações imediatamente após 11 de setembro - Edições 1 718, 1 719, 1720 e 1721 186

4.7.3 - Fontes utilizadas por Veja nas publicações um ano após 11 de setembro - Edições 1 768, 1 769, 1 770, 1771

4.7.4 - Fontes fotográficas utilizadas por Veja nas publicações pré11 de setembro - Edições 1 666, 1 667, 1 668, 1669.

4.7.5 - Fontes fotográficas utilizadas por Veja nas publicações imediatamente após 11 de setembro - Edições 1 718, 1 719, 1720 e 1 721 189

4.7.6 - Fontes fotográficas utilizadas por Veja nas publicações um ano após 11 de setembro - Edições 1 768, 1 769, 1 770, 1771 190

Considerações finais 192

Referências bibliográficas. 


\section{Lista de tabelas, figuras e textos}

Texto 1: Reportagem revista Veja edição 1666 - 13 de setembro de 2000 .62

Texto 2: Reportagem revista Veja edição 1667 - 20 de setembro de 2000 .68

Texto 3: Reportagem revista Veja edição 1668 - 27 de setembro de 2000 .72

Texto 4: Reportagem revista Veja edição 1669 - 4 de outubro de 2000 .79

Texto 5: Carta ao leitor revista Veja - Edição especial 1718 - 19 de setembro de 2001 87

Texto 6: Reportagem revista Veja - Edição especial 1718 - 19 de setembro de 2001 90

Texto 7: Reportagem revista Veja edição 1719 - 26 de setembro de 2001 101

Texto 8: Reportagem revista Veja edição 1719 - 26 de setembro de 2001 106

Texto 9: Reportagem revista Veja edição 1720 - 3 de outubro de 2001

Texto 10: Reportagem revista Veja edição 1720 - 3 de outubro de 2001 129

Texto 11: Reportagem revista Veja edição 1721 - 10 de outubro de 2001 134

Texto 12: Reportagem revista Veja edição 1721 - 10 de outubro de 2001 139

Texto 13: Reportagem revista Veja edição 1768 - 11 de setembo de 2002 
Texto 14: Reportagem revista Veja edição 1769 - 18 de setembo de 2002. 153

Texto 15: Reportagem revista Veja edição 1770 - 25 de setembo de 2002 163

Texto 16: Reportagem revista Veja edição 1771 - 2 de outubro de 2002 170

Tabela 1: Reportagem revista Veja edição 1666 - 13 de setembro de 2000 62

Tabela 2: Reportagem revista Veja edição 1667 - 20 de setembro de 2000 .70

Tabela 3: Reportagem revista Veja edição 1668 - 27 de setembro de 2000 77

Tabela 4: Reportagem revista Veja edição 1669 - 4 de outubro de 2000 .80

Tabela 5: Carta ao leitor revista Veja - Edição especial 1718 - 19 de setembro de 2001 .87

Tabela 6: Reportagem revista Veja - Edição especial 1718 - 19 de setembro de 2001 95

Tabela 7: Reportagem revista Veja edição 1719 - 26 de setembro de 2001 103

Tabela 8: Reportagem revista Veja edição 1719 - 26 de setembro de 2001 111

Tabela 9: Reportagem revista Veja edição 1720 - 3 de outubro de 2001 120

Tabela 10: Reportagem revista Veja edição 1720 - 3 de outubro de 2001 131

Tabela 11: Reportagem revista Veja edição 1721 - 10 de outubro de 2001 
Tabela 12: Reportagem revista Veja edição 1721 - 10 de outubro de 2001 142

Tabela 13: Reportagem revista Veja edição 1768 - 11 de setembo de 2002 148

Tabela 14: Reportagem revista Veja edição 1769 - 18 de setembo de 2002 156

Tabela 15: Reportagem revista Veja edição 1770 - 25 de setembo de 2002 165

Tabela 16: Reportagem revista Veja edição 1771 - 2 de outubro de 2002 171

Tabela 17: Distribuição das unidades textuais para o ano de 2000 de acordo com a quantidade de textos total. 177

Tabela 18: Distribuição das unidades textuais para o ano de 2001 de acordo com a quantidade de textos total. 178

Tabela 19: Distribuição das unidades textuais para o ano de 2002 de acordo com a quantidade de textos total.

Tabela 20: Distribuição das unidades textuais para os três anos em estudo. 181

Tabela 21: Países citados 182

Tabela 22: Tipo de discurso da unidade textual 183

Tabela 23: Operações discursivas 183

Tabela 24: Distribuição das fontes de notícias para 2000 185

Tabela 25: Distribuição das fontes de notícias para 2001 186

Tabela 26: Distribuição das fontes de notícias para 2002.

Tabela 27: Distribuição das fontes de notícias nos três períodos 188

Tabela 28: Distribuição das unidades fotográficas de acordo com a fonte para 2000.

Tabela 29: Distribuição das unidades fotográficas de acordo com a fonte para 2001 
Tabela 30: Distribuição das unidades fotográficas de acordo com a fonte para 2002 190

Tabela 31: Distribuição das unidades fotográficas de acordo com a fonte para os três anos de estudo. 190

Figura 1: Dimensões discursivas. .45

Figura 2: Enquadramento econômico. 165

Figura 3: Gráfico da distribuição percentual para assuntos em estudo citados nos anos de 2000, 2001 e 2002 181 Figura 4: Distribuição percentual para países citados nos anos de 2001 e 2002 184

Figura 5: Gráfico para a distribuição das fontes de informação utilizadas por Veja para o ano 2000 185

Figura 6: Gráfico para a distribuição das fontes de informação utilizadas por Veja para o ano 2001 186 Figura 7: Gráfico para a distribuição das fontes de informação utilizadas por Veja para o ano 2002 187

Figura 8: Gráfico para a distribuição das fontes de informação utilizadas por Veja para os três anos em estudo: 2000, 2001 e 2002 188 Figura 9: Gráfico para a distribuição percentual de unidades fotográficas utilizadas por Veja para os anos em estudo 


\section{Introdução}

Faltavam poucos minutos para as $10 \mathrm{~h}$ quando as notícias começaram a chegar pela televisão. Um Boeing 767-223, da companhia American Airlines, havia se chocado minutos antes contra a torre norte do World Trade Center, em Nova York, nos Estados Unidos. Quando as agências de notícias já abasteciam as redações com informações da tragédia, as emissoras de TV transmitiram ao vivo um segundo choque. Dessa vez, um Boeing 767-222, da United Airlines, atingia a torre sul do complexo de edifícios de 110 andares construído entre o fim da década de 1960 e o início dos anos 1970. Nas horas seguintes, outros dois aviões ainda cairiam - o primeiro sobre o Pentágono, sede do comando militar norte-americano, nas proximidades de Washington, e o segundo em uma área desabitada em Shanksville, na Pensilvânia. Ainda na manhã daquela terçafeira, sites de notícias já noticiavam a possibilidade de as colisões serem ações de muçulmanos. A agência de notícias Reuters chegou a informar, segundo os sites noticiosos brasileiros, que um grupo palestino teria assumido a autoria do atentado. Era o 11 de setembro.

A data ganhou marca indelével em uma nova agenda da imprensa mundial. Um novo capítulo da relação entre Ocidente e Oriente estabelecia-se através do enunciado do então presidente norte-americano George W. Bush: “ou você está 'conosco' ('o mundo democrático') ou com 'eles' ('os terroristas')". Seria um sinal para a necessidade de uma tomada de posição que não envolvia apenas relações diplomáticas e geopolíticas, mas também uma nova maneira de ver o mundo. E a imprensa, como ferramenta peremptória na elaboração, consolidação e difusão de representações em larga escala, teve papel fundamental nessa conjuntura.

\footnotetext{
Commentators - politicians, journalists and others - continue to argue that the events of 11 September signal a kind of rupture, that the world has changed irrevocably and that a new world order must be established in the aftermath. At a global level, the media have played a role in constructing this idea in the psychic imagination. As the live feed projected into our spaces of consumption and people's script of previous events informed their interpretation of this one, new boundaries were being formed, allegiances solidified, people excluded, and "us" and "them" created in varying forms across the globe (POOLE, 2002, p. 1-2) ${ }^{1}$
}

\footnotetext{
1 “Comentaristas - politicos, jornalistas e outros - continuam argumentando que os eventos do 11 de setembro sinalizam um tipo de ruptura, que o mundo mudou de maneira irrevogável e que uma nova ordem mundial deve ser estabelecida após tudo isso. Em nível global, a mídia desempenhou um papel na
} 
É como nos adverte Anthony Giddens (2002, p. 12):

Na alta modernidade, a influência de acontecimentos distantes sobre eventos próximos, e sobre a intimidade do eu, se torna cada vez mais comum. A mídia impressa e eletrônica obviamente desempenha um papel central. A experiência canalizada pelos meios de comunicação, desde a primeira experiência da escrita, tem influenciado tanto a autoidentidade quanto a organização das relações sociais.

Assim, pareceu-nos fundamental o trabalho de investigar a produção jornalística brasileira no que tange aos assuntos relacionados à representação desse novo cenário contruído a partir dos ataques em 11 de setembro. Partimos da premissa de que o jornalismo brasileiro tem o jornalismo norte-americano como modelo (SILVA, 1991), mas não apenas em seu aspecto organizacional. Como diz Viviane Ramalho (2005, p. 144-45) em sua pesquisa sobre o discurso da imprensa brasileira a respeito da invasão anglo-saxônica ao Iraque ${ }^{2}$ :

\begin{abstract}
A própria condição economicamente desfavorável do Brasil em relação aos EUA [...] torna o discurso da mídia brasileira significativamente dependente do Império [...] quer seja por compartilhar dos interesses do mercado neoliberal competitivo, quer seja por ter como fonte principal o discurso do invasor como fonte principal.
\end{abstract}

A hipótese por nós trabalhada é a de que, através de mecanismos textuais, o veículo escolhido para compor o corpus de análise reproduz o discurso hegemônico norte-americano e sustenta, assim, uma visão naturalizada das posições e interesses desse país como legítimas. Isso contribui para a construção e a manutenção de uma identidade negativa dos que professam sua fé na religão islâmica, não oferecendo aos seus leitores uma pluralidade de opiniões acerca das questões que envolvem as pessoas desta religião. Acreditamos, no entanto, que apenas mapear e revelar o que o discurso de Veja diz não daria conta da complexidade de nosso objetivo, tornando-se, assim, necessário não apenas identificar os enunciados e seus possíveis significados, mas apontar como eles são organizados, mapear as operações que os constroem, compreendê-los na estreiteza e singularidade de sua situação, como diz Michel Foucault

construção dessa ideia nessa imaginação psíquica. Enquanto a transmissão ao vivo projetava em nossos espaços de consumo e o roteiro de eventos prévios das pessoas informava suas interpretações, novas fronteiras estavam sendo formadas, sujeições solidificadas, pessoas excluídas, e 'nós' e 'eles' criados em diversas formas através do globo."

\footnotetext{
${ }^{2}$ Disponível em :< http://bdtd.bce.unb.br/tedesimplificado/tde_arquivos/56/TDE-2007-09-20T150821Z-
} 1784/Publico/Dissert_Viviane\%20Cristina\%20Vieira.pdf $>$. 
(2010, p. 31), e determinar as condições de sua situação e, para além disso, estabelecer suas relações com outros enunciados.

Encontramos suporte para tal elaboração em duas vertentes teóricas. Primeiro, no pensamento de Edward W. Said e sua teoria do Orientalismo ${ }^{3}$, um "estilo de pensamento baseado em uma distinção ontológica e epistemológica feita entre o 'Oriente' e (a maior parte do tempo) o 'Ocidente'” (1990, p. 14) ${ }^{4}$. Apresentada no livro Orientalismo - O Oriente como invenção do Ocidente, a teoria de Said indica que o Orientalismo foi aceito como

[...] ponto de partida para elaboradas teorias, épicos, romances, descrições sociais e relatos políticos a respeito do Oriente, dos seus povos, costumes, "mente" [...] podendo ser discutido e analisado como a instituição organizada para negociar com o Oriente - negociar com ele fazendo declarações a seu respeito, autorizando opiniões sobre ele, descrevendo-o, colonizando-o, governando-o: em resumo, o orientalismo como um estilo ocidental para dominar, reestruturar e ter autoridade sobre o Oriente (SAID, p. 14-15).

A teoria do Orientalismo será discutida no Capítulo I, mas não apenas o livro onde ela foi primeiramente apresentada nos dará sustentação. Outra obra fundamental de Said amplamente utilizada neste trabalho será Covering Islam (1997), que expõe reflexão do autor sobre o comportamento dos jornalistas no contexto dessa relação entre Ocidente e Oriente, especialmente na cobertura que é realizada quando o tema em questão é o Islã e o alinhamento automático da maioria dos jornalistas com posições norte-americanas, o que leva Said a perguntar "why the extraordinary willingness to accept the official rhetoric emanating from the government in its irresponsible characterizations of Islam" (SAID, 1997, p. xxxix) ${ }^{5}$.

Tendo como pressupostos que "a língua, no seu uso prático, é inseparável de seu conteúdo ideológico ou relativo à vida" (BAKHTIN, 1992, p. 96) e que "o orientalismo deve ser analisado como um discurso" (SAID, 1990, p. 15), utilizamos também em nosso quadro teórico de referências a Teoria Social do Discurso, abordagem da Análise de Discurso Crítica (ADC) que, segundo seu idealizador, Norman Fairclough (2003), "is based upon the assumption that language is an irreducible part of social life,

\footnotetext{
${ }^{3}$ Neste trabalho, utilizaremos a grafia Orientalismo para referência à teoria saidiana e orientalismo para a prática orientalista.

${ }^{4}$ Neste trabalho, usarei duas edições diferentes do livro Orientalismo - O Oriente como invenção do Ocidente. Uma da Companhia das Letras, de 1990, com tradução de Tomás Rosa Bueno, e outra da Companhia de Bolso, de 2007, com tradução de Rosaura Eichenberg, onde constam um prefácio e um posfácio de outras edições lançadas no Brasil.

5 “por que a extraordinária disposição para aceitar a retórica oficial que vem do governo em suas irresponsáveis caracterizações do Islã
} 
dialectically interconnected with other elements of social life, so that social analysis and research always has to take account of language" (FAIRCLOUGH, 2003, p. 2) ${ }^{6}$. A associação entre o Orientalismo e a ADC não encontra contradições. Sabe-se que alguns pesquisadores, como Michael Stubbs (1996, 1997), por exemplo, chegam a defender que a teoria saidiana pertence à Análise do Discurso Crítica.

E cientes de que o trabalho jornalístico só pode ser analisado se relacionado com as condições políticas dentro das quais ele é produzido (POOLE, 2002), a utilização da Teoria Social do Discurso, discutida no Capítulo II, se justifica por conjugar transdisciplinarmente teorias e métodos da Linguística e da Ciência Social Crítica (RAMALHO, 2005, p. 12), com especial atenção para uma análise detalhada do produto final do trabalho do jornalista, ou seja, do texto:

\begin{abstract}
My own approach to discourse analysis has been to try to transcend the division between work inspired by social theory which tends not to analyze texts, and work which focuses upon the language of texts but tends not to engage with social theoretical issues. This is not, or should not be, an 'either/or'. On the one hand, any analysis of texts which aims to be significant in social scientific terms has to connect with theoretical questions about discourse (e.g. the socially 'constructive' effects of discourse). On the other hand, no real understanding of the social effects of discourse is possible whithout looking closely at what happens when people talk or write. (FAIRCLOUGH, 2003, p. 2-3) ${ }^{7}$
\end{abstract}

O corpus desta pesquisa é composto por 12 edições da revista Veja, publicação semanal da Editora Abril. A escolha de tal veículo de comunicação deu-se por dois motivos que se somam. Por Veja registrar a maior tiragem entre as publicações noticiosas brasileiras, com média registrada em junho de 2010 de 1.097 .490 exemplares por semana, o que a coloca como a maior do Brasil em circulação e a terceira maior do mundo, atrás apenas das publicações norte-americanas Time e Newsweek, segundo informações da Editora Abril através de sua assessoria de imprensa. E, para além disso, especialmente pelo papel que a publicação representa há quase meio século na

\footnotetext{
6 "Está baseada na suposição de que a linguagem é uma parte irredutível da vida social, dialeticamente interconectada com outros elementos da vida social, assim, a análise social e pesquisa sempre têm que levar a linguagem em conta"

7 "Minha própria abordagem da análise do discurso tem sido tentar transcender a divisão entre o trabalho inspirado pela teoria social que tende a não analisar textos e o trabalho cujo foco recai sobre a linguagem dos textos mas tende ao não engajamento com as questões de teoria social. Isso não é,ou pelo menos não deveria ser, um ou outro. De um lado, qualquer análise de textos que tem como meta ser significante em termos científicos sociais tem que conectar-se com questões teóricas sobre o discurso (exemplo: os efeitos socialmente formadores do discurso). Por outro lado, não é possível um real entendimento dos efeitos sociais do discurso sem um olhar mais próximo sobre o que acontece quando as pessoas falam ou escrevem."
} 
sociedade brasileira. Em O leitor e a banca de revista: o caso da Editora Abril (1997, p. 129), Maria Celeste Mira diz que ao longo dos anos Veja tem sido a porta-voz econômica e política de seu grupo empresarial. "Por isto, seu papel ideológico nestes campos é crucial. Através de suas matérias, procura-se 'mudar a cabeça das pessoas', como disse Roberto Civita”. Tal afirmação nos leva às palavras da professora Mayra Rodrigues Gomes (2003, p. 33). Quando, refletindo sobre o indivíduo e sua situação na ordem simbólica, ela nos diz que

[...] primeiramente devemos levar em conta um modo específico pelo qual o sujeito entra no mundo social. Ele encontra organizações que lhe precedem, ordenações que lhe mostram ou indicam o que deve ser visto. $\mathrm{O}$ mundo a ser vivido lhe é apresentado numa configuração abrangente, direcionando o entendimento e assinalando prioridades.

Da mesma maneira, Deleuze e Guattari (1995, p. 16), referências evidenciadas por Gomes, nos dizem que "os jornais, as notícias, procedem por redundância, pelo fato de nos dizerem o que é 'necessário' pensar". E é esse o papel com o qual Veja se apresenta, o de nos dizer como é o mundo.

As 12 edições que compõem o corpus estão dividas em quatro edições publicadas entre os dias 13 de setembro e 4 de outubro do ano 2000 - um ano antes dos ataques de 11 de setembro -; quatro edições entre 19 de setembro e 10 de outubro de 2001 - quatro edições publicadas nas quatro semanas seguintes aos ataques-; e, por fim, quatro edições publicadas entre os dias 11 de setembro e 2 de outubro de 2002 - exato um ano após os ataques. Devido à diferença no número de textos que tratam de assuntos ligados ao Islã nos três diferentes períodos, estabelecemos que o segundo período (2001) teria oito unidades textuais analisadas - duas em cada um dos quatro exemplares estudados, uma vez que as edições foram lançadas logo após os atentados e, com isso, refletiram uma atenção maior dedicada à questão - enquanto o primeiro (2000) e o terceiro (2002) períodos teriam uma unidade textual analisada em cada uma das edições do corpus. O recorte foi dessa maneira elaborado para que fosse possível estabelecer comparações entre a cobertura de fatos ligados ao Islã antes e depois do 11 de setembro de 2001, uma vez que trabalhamos com a hipótese de que a imprensa estabelece uma simplista associação entre o Islã e conceitos como fundamentalismo, intolerância, irracionalidade e violência.A aplicação dos conceitos da análise de textos elaborados pela Teoria Social do Discurso dar-se-á tanto em um aspecto qualitativo, como já explicitado, quanto quantitativo, assim como recomenda Fairclough (2003, p. 6), por considerar que: “[...] this form of qualitative analysis can usefully be supplemented by 
the 'quantitative analysis' offered by corpus linguistics" 8 . Acreditamos também que essa característica híbrida de análise é metodologicamete reforçada por promover

[...] uma integração entre as duas visões de forma que os conteúdos manifesto (visível) e latente (oculto, subentendido) sejam incluídos em um mesmo estudo para que se compreenda não somente o significado aparente de um texto, mas também o significado implícito, o contexto onde ele ocorre [...] (HERSCOVITZ, 2007, p. 126)

\footnotetext{
8 "Essa forma de análise qualitativa pode proveitosamente ser suplementada por uma 'análise quantitativa' oferecida pelo corpus linguístico."
} 


\section{Capítulo I - Orientalismo}

\section{1 - Apresentação}

Edward Wadie Said nasceu em Jerusalém, em 1935, com a Palestina ainda sob controle britânico, e passou a maior parte da infância na cidade do Cairo, no Egito. Filho de uma rica família cristã, foi educado em colégios americanos e britânicos, como St George's School, Victoria College, Cairo School for American Children, e Gezira Preparatory School. Nessas escolas conta ter vivido a "primeira experiência de um sistema organizado estabelecido como negócio colonial pelos britânicos [...] o primeiro contato continuado com a autoridade colonial [...]" (2004, p. 73-74). Foi também na Palestina que vivenciou uma experiência que teria clara influência em sua produção intelectual, o nascimento do Estado de Israel.

\footnotetext{
Ainda é difícil aceitar o fato de que os bairros da cidade onde nasci, vivi e me senti em casa foram tomados por imigrantes poloneses, alemães e americanos que conquistaram a cidade e a transformaram em símbolo supremo de sua soberania, sem lugar para a vida palestina (2004, p. 169).
}

Em 1951, por insistência do pai - que quando jovem emigrara para os Estados Unidos, lutara pelo país na Primeira Guerra Mundial e de lá voltara como cidadão norteamericano -, foi enviado para Massachusetts, na costa leste americana, para dar sequência aos seus estudos no colégio Mount Hermon. A graduação foi realizada em Princeton, de onde partiu para Harvard, onde realizou mestrado e doutoramento em Literatura Inglesa.

O trânsito entre os dois mundos - o ocidental e o oriental -, entre os dois idiomas - o árabe e o inglês, uma vez que Said nunca conseguiu definir qual língua aprendeu primeiro -, e até mesmo a ambiguidade de seu nome Edward - inglês, em homenagem ao príncipe de Gales - atrelado à força do sobrenome Said, inequivocamente árabe, imprimiu forte marca em sua trajetória intelectual e revelou-se em sua contrariedade com as generalizações e estigmas. Um exemplo encontra registro em fato vivenciado ainda na adolescência por Said em companhia de sua mãe. Por ter passaporte libanês, ela enfrentava grandes dificuldades para conseguir visto para a Europa e Estados Unidos, além de contratempos ao tentar passar por barreiras de imigração. De acordo 
com Said, "ser libanês havia de repente se tornado sinônimo de ter tendência para o terrorismo" (2004, p. 200).

A partir de 1963, e ao longo de quatro décadas, Edward Said lecionou nos departamentos de Inglês e Literatura Comparada da Universidade de Columbia, em Nova York. E foi na maior cidade americana que escreveu seu mais conhecido trabalho: Orientalism.

Lançado em 1978, foi publicado no Brasil 12 anos mais tarde pela editora Companhia das Letras com o título Orientalismo: o Oriente como invenção do Ocidente. A obra original recebeu dois complementos. O primeiro deles lançado como posfácio na edição de 1995 da editora Penguin Books; o segundo, um prefácio publicado na edição comemorativa de 25 anos de lançamento de Orientalism pela mesma editora.

Segundo Said, seu interesse pelo orientalismo começou por dois motivos principais. Um ligado a sua própria história de vida e à disparidade sentida entre sua experiência como árabe e o que percebia como representação árabe nas artes. E o segundo, mais imediato, ligado à guerra árabe-israelense em 1973.

[...] which had been preceded by a lot of images and discussions in the media in the popular press about how the Arabs are cowardly and they don't know how to fight and they are always going to be beaten because they are not modern $[\ldots]^{9}$

O trabalho jornalístico, como se vê, desempenha importante papel nas reflexões saidianas. Não por outro motivo, a prática jornalística aparece nas primeiras linhas de Orientalismo: o Oriente como a invenção do Ocidente.

Em uma visita a Beirute durante a terrível guerra civil de 1975-6, um jornalista francês escreveu com pesar sobre a devastada área central da cidade que ela "parecera outrora pertencer [...] ao Oriente de Chateaubriand ou Nerval". ${ }^{10}$ Ele tinha razão sobre o lugar, é claro, especialmente no que dizia respeito a um europeu. O Oriente era quase uma invenção europeia, e fora desde a Antiguidade um lugar de romances, seres exóticos, de memórias e paisagens obsessivas, de experiências notáveis. (SAID, 1990, p. 13)

\footnotetext{
9 “a qual tinha sido precedida por uma grande quantidade de imagens e discussões na mídia, na imprensa popular, sobre como os árabes são covardes, não sabem lutar, e serão sempre vencidos por não serem modernos". Entrevista concedida ao Media Education Foundation em 2005. Disponível em: <http://www.mediaed.org/assets/products/403/transcript_403.pdf.>.

${ }^{10}$ Thierry Desjardin, Le martyre du Liban (Paris, Plon, 1976), p. 14.
} 
Segundo Said, formalmente o orientalismo começou com a decisão do Concílio de Viena, em 1312, de estabelecer uma série de cátedras de árabe, grego, hebraico e sírio. Até meados do século XVIII, no entanto, os orientalistas eram apenas estudiosos bíblicos, estudantes de idiomas, semíticos ou especialistas islâmicos, sendo que até o século XIX, com o Institute d'Egypte, de Napoleão, não se dava muita atenção para o estudo do Oriente moderno ou existente, preferindo-se sempre o clássico. (1990, p. 6162)

Há três sentidos para o Orientalismo, de acordo com a elaboração saidiana. O acadêmico é o primeiro deles: "qualquer um que dê aulas, escreva ou pesquise sobre o Oriente [...] é um orientalista, e aquilo que ele ou ela faz é orientalismo". O segundo sentido é o imaginativo, "um estilo de pensamento baseado em uma distinção ontológica e epistemológica feita entre 'o Oriente' e (a maior parte do tempo) 'o Ocidente"” (SAID, 1990, p. 14). E o terceiro, resultado de um intercâmbio entre os sentidos anteriores, recai sobre a noção de discurso encontrada nos escritos de Michel Foucault (2010, p. 55), para quem "os discursos são feitos de signos; mas o que fazem é mais que utilizar esses signos para designar coisas. É esse mais que os torna irredutíveis à lingua e ao ato de fala". Ou seja, o filósofo francês defende "não mais tratar os discursos como conjuntos de signos [...] mas como práticas que formam sistematicamente os objetos de que falam". Para Said (2009), de outra maneira "não se pode entender a disciplina enormemente sistemática por meio da qual a cultura europeia conseguiu administrar - e até produzir - o Oriente política, sociológica, ideológica, científica e imaginativamente durante o período pós-Iluminismo". Em resumo, é impossível pensar e agir livremente sobre o Oriente, uma vez que o orientalismo, como uma rede de interesses, faz valer seu prestígio sempre que “o Oriente” está em questão. São estes os pontos centrais da teoria de Said, que "tenta também mostrar que a cultura europeia ganhou em força e identidade comparando-se com o Oriente como uma espécie de identidade substituta e até mesmo subterrânea, clandestina” (2009, p. 15).

O Oriente está para a Europa como "seu concorrente cultural e uma das suas mais profundas e recorrentes imagens do Outro" (2009, p. 13). Ao dizer isso, Said traz para suas reflexões o conceito do Outro, encontrado em Lacan (1998, p. 96-103), para quem o Outro "faz a função de espelho e permite a unificação da imagem de si necessária para a constituição do narcisismo que sustenta o Eu" (KEHL, 2003, p. 252). A maneira como o Ocidente molda o Oriente através do que escreve e diz sobre ele encontra explicação 
no conceito lacaniano de que os corpos não existem fora da linguagem. As práticas da linguagem são o que determina a aparência e a expressividade dos corpos, que se modificam por efeito do que se diz sobre eles. O corpo responde ao discurso feito sobre ele e, com isso, a um corpo investido de um novo discurso corresponde um outro eu. (idem, p. 245-6). A reflexão pode ser ampliada para a questão dos grandes grupos populacionais com o suporte do pensamento de Stuart Hall (1999, p. 50), para quem a cultura nacional também é um discurso, "um modo de construir sentidos que influencia e organiza tanto nossas ações quanto a concepção que temos de nós mesmos" .

Refletimos sobre esse conceito de identidade apoiados no pensamento do professor Tomaz Tadeu da Silva (2000). Ela é pensada em direta associação com a diferença, uma vez que os conceitos se entrelaçam, como se vê no exemplo abaixo.

\footnotetext{
A afirmação "sou brasileiro", na verdade, é parte de uma extensa cadeia de negações, de expressões negativas de identidade, de diferenças. Por trás da afirmação "sou brasileiro" deve-se ler: "não sou argentino", "não sou chinês", "não sou japonês" e assim por diante, numa cadeia, nesse caso, quase interminável (SILVA, 2000, p. 75).
}

Para além desta relação de dependência, Silva aponta para o fato de identidade e diferença se estabelecerem nas relações sociais e, portanto, estarem sujeitas a vetores de força nas relações de poder. "Elas não são simplesmente definidas; elas são impostas [...] elas não convivem harmoniosamente, lado a lado, em um campo sem hierarquias; elas são disputadas." (2000, p. 81)

Em Os Estabelecidos e os Outsiders, Norbert Elias e John L. Sootson (2009) avaliaram o comportamento de um grupo da comunidade de nome fictício Winston Parva, onde se encontrava, "como que em miniatura, um tema universal". E descobriram que "podemos observar que os membros dos grupos mais poderosos que outros grupos interdependentes se pensam a si mesmos (se autorrepresentam) como humanamente superiores" (2009, p. 19) em várias situações, entre elas as que envolvem os Estados nacionais grandes e poderosos em relação a Estados menores. Em suas observações, Elias e Sootson notaram que o grupo de antigos residentes estabelecera para si um conjunto de normas e um estilo de vida comum. Os recém-chegados eram vistos como uma ameaça a esse estilo de vida. O resultado disso foi que "para preservar o que julgavam ter alto valor, eles cerravam fileiras contra os recém-chegados, com isso protegendo sua identidade grupal e afirmando sua superioridade". (2009, p. 25). Tal paralelo é encontrado na relação entre Ocidente e Oriente, com especial atenção a um 
componente fundamental: o Islã, "visto como uma versão fraudulenta de uma experiência prévia, no caso o cristianismo" (SAID, 1990, p. 69).

Em um primeiro momento, ainda antes do surgimento do Islã, os árabes eram pouco conhecidos nos países europeus. O desinteresse ocidental pelo povo da Península Arábica, no entanto, não impediu que ele fosse retratado como violento, como mostra Maxime Rodinson (1989, p. 17 apud SOMMA, 2003, p. 18) ao citar a obra Expositio totius mundi et genium, de autor desconhecido: "Una descripción del mundo escrita en el siglo VI, por ejemplo, aseguraba que (os árabes) se procuraban 'mediante el arco y la rapiña todo cuanto necesitavan para vivir"” 11. À ignorância uniu-se o medo, especialmente a partir do século VII, com o crescimento do poder militar, cultural e religioso do Islã, que com seu exército conquistou Pérsia, Síria, Egito, depois Turquia e África do Norte, Espanha, Sicília e parte da Espanha. $\mathrm{O}$ avanço seguiu até o século XIV, quando o domínio muçulmano chegava até a Índia, Indonésia e China.

Diante de tal quadro, Said (1990) considera natural a reação conservadora e defensiva do poder europeu e católico a uma forma de vida considerada totalmente nova, que era como surgia o Islamismo na Idade Média. Segundo ele, não foi sem razão que a nova crença assustou o poder estabelecido.

O Islã foi uma provocação real à Europa. Estava próximo geograficamente e culturalmente. Vangloriava-se de êxitos positivos e militares. Nutria-se de tradições judeu-helênicas, fazia empréstimos do cristianismo. Suas terras estavam sobrepostas às terras bíblicas. Árabe e hebreu são línguas semíticas e juntas dispõem de um material importante para o cristianismo. Do fím do século VII até 1571 o Islã ameaçou a cristandade europeia com suas formas árabe, otomana, norte- africana ou espanhola. (SAID, 1990, p. 69-83)

O saber orientalista considerava os orientais uma espécie dotada de menor capacidade intelectual. Exemplo disso está no 34 capítulo de Modern Egypt, o relato em dois volumes das realizações do representante da Inglaterra no Egito, Evelyn Baring, o lord Cromer, que também governou a Índia, e considerava que:

\begin{abstract}
A mente do oriental [...], assim como suas pitorescas ruas, é eminentemente carente de simetria. Embora os antigos árabes tenham adquirido em um grau um tanto mais alto a ciência da dialética, seus descendentes são singularmente deficientes de faculdades lógicas. São muitas vezes incapazes de tirar as conclusões mais óbvias de qualquer simples premissa cuja verdade possam admitir (CROMER apud SAID, 1990, p. 48).
\end{abstract}

\footnotetext{
11 “Uma descrição do mundo escrita no século VI, por exemplo, assegurava que (os árabes) procuravam 'pelo arco e pela rapina tudo que necessitavam para viver"'.
} 
Norman Daniel (2003), cujo trabalho Islam and the West: The making of a Image foi grande influência para Said, diz que o Islã tornou-se uma imagem cuja função não era tanto representar o Islã em si quanto representá-lo para o cristão medieval. "Islamic institutions were confused with Christian ones, and were criticized for not being identical with them" (2003, p. 252). ${ }^{12}$

Se até meados do século XVIII o orientalismo estava limitado ao estudo bíblico e dos idiomas, voltado especialmente ao estudo do clássico Oriente e não ao moderno e atual, entre o fim do século XVIII e início do XIX ele começa a ser posto em prática. Em seus planos para invasão do Egito, Napoleão Bonaparte utilizou todo o aparato orientalista na campanha que levou a Grand Armée rumo ao norte da África. O primeiro cronista árabe da expedição, Abd-al-Rahman al-Jabarti, contou ter ficado impressionado com o fato de Napoleão ter utilizado estudiosos para seus contatos com os nativos (ABU-LUGHOD apud SAID, 1990, p. 90-1). Napoleão tinha sido fortemente influenciado pelo conde de Volney em dois de seus escritos, Considérations sur la guerre actuelle des turcs e Voyage en Égipt et en Syrie ${ }^{13}$.

O discurso orientalista se transforma. O realismo descritivo é promovido e tornase não apenas um estilo de representação, mas uma linguagem, um meio de criação. "A partir de então o Oriente islâmico apareceria como uma categoria que denotaria o poder dos orientalistas, e não os islamitas como seres humanos nem a história deles como história". (SAID, 1990, p. 96). Este é o fio que liga a gênese orientalista ao orientalismo moderno, mais uma camada do alicerce que sustenta a maneira como enxergamos o Oriente hoje.

Entre as décadas de 20 e 50 do século XX, França e Inglaterra assistem a um movimento anticolonialista no Oriente Médio e ao surgimento de duas novas potências mundiais, os Estados Unidos e a União Soviética. O orientalismo não demora a responder à nova configuração geopolítica e prefere manter o Islã no século VII, sendo reduzido a "tenda e tribo" (1990, p. 114). Tendo como base a obra de Renan ${ }^{14}$, Sacy ${ }^{15}$

\footnotetext{
12 “Istituições islâmicas eram confundidas com instituições cristãs, e criticadas por não serem idênticas a elas."

${ }^{13}$ Constantin-François Volney, Voyage en Égipt et en Syrie (Paris, Bossange, 1821, p. 241 e passim).

${ }^{14}$ Joseph Ernest Renan, francês, filósofo, filólogo e historiador, nasceu em 28 de fevereiro de 1823 e morreu em 2 de outubro de 1892. Escreveu, entre outros, História Geral das Línguas Semíticas.

${ }^{15}$ Antoine Isaac, barão Silvestre de Sacy, francês, nasceu em 21 de setembro de 1758 e morreu em 21 de fevereiro de 1838. Escreveu, entre outros, Expose de la religion des Druzes.
} 
e Lane ${ }^{16}$, os modernos orientalistas têm agora o seu campo de estudos calcado em uma base científica e racional, o que levou à criação de um vocabulário e de ideias que podiam ser usados impessoalmente por qualquer um que quisesse ser orientalista.

Como um juiz do oriente, o moderno orientalista não está, como acredita e até mesmo diz, separado dele objetivamente. O seu distanciamento humano, cujo sinal é a ausência de simpatia, disfarçada de conhecimento profissional, está pesadamente carregado com todas as atitudes, perspectivas e humores ortodoxos do orientalismo [...] O oriente dele não é o oriente tal qual ele é, mas o oriente tal qual foi orientalizado. (SAID, 1990, p. 113).

Norbert Elias e John L. Sootson analisaram a construção que rejeita a subjetividade no processo que leva à reificação do outro na relação entre grupos de dominantes e dominados.

O estigma social que seus membros atribuem ao grupo de outsiders transforma-se, em sua imaginação, num estigma material - é coisificado. Surge como uma coisa objetiva, implantada nos outsiders pela natureza ou pelos deuses. Dessa maneira, o grupo estigmatizador é eximido de qualquer responsabilidade: não fomos nós, implica essa fantasia, que estigmatizamos essas pessoas e sim as forças que criaram o mundo - elas é que colocaram um sinal nelas, para marcá-las como inferiores ou ruins. (ELIAS; SOOTSON, 2000, p. 35).

\subsection{1 - Preconceito e estereótipo}

O conceito de preconceito é definido por Mazzara como algo que em seu nível máximo de especificidade é entendido como "la tendencia a considerar de modo injustificadamente desfavorable a las personas que pertencen a un determinado grupo social" ${ }^{17}$. Já estereótipo, que é um termo de origem mais recente, nascido nas ciências sociais, é utilizado quando "la relación cognoscitiva con la realidad externa no es directa

\footnotetext{
${ }^{16}$ Edward William Lane, inglês, nasceu em 17 de setembro de 1801 e morreu em 10 de agosto de 1876. Escreveu, entre outros, Manners and Customs of the Modern Egyptians.

17 "A tendência a considerar de modo injustificavelmente desfavorável as pessoas que pertencem a um determinado grupo social."
} 
sino que se realiza a través de las imágenes mentales que cada uno se forma de esa" ${ }^{18}$. Reunindo os dois conceitos chegamos ao fato de que o preconceito nasce do estereótipo.

Definido el prejuício como la tendencia a pensar (y actuar) de forma desfavorable frente a un grupo. Podemos ahora agregar que tal disposición desfavorable se apoya en la convicción de que ese grupo o categoría posee en forma bastante homogènea los rasgos que se consideran negativos. En este sentido, como se ha dicho el estereotipo puede considerarse el núcleo cognitivo del prejuício. (MAZZARA, 1999, p. 12-16) ${ }^{19}$

Mazzara chama a atenção para a necessidade de identificarmos erros cognitivos que constituem alguns aspectos que ajudam a explicar psicologicamente o preconceito. Entre eles estão os que têm origem nos costumes e na interação entre os seres humanos, sendo preciso considerar, em primeiro lugar, a linguagem, que "puede poner limites y alzar barreras artificiales entre las cosas, convirtiéndose en un obstáculo para el verdadero conocimiento, tanto que aun las mentes más capaces pueden caer en su trampa sin advertírlo" ${ }^{20}$, e os erros causados pelas tradições e falsas teorias do passado, "las tradiciones en la forma de pensar, una vez consolidadas, tienden a imponer sus proprias explicaciones" (MAZZARA, 1999, p. 10-11) ${ }^{21}$. Tais construções estão na base da formação do discurso orientalista, mas nelas próprias não se esgotam, conduzindo a um terceiro conceito: o estigma. Como relembra Goffman (2008), o termo foi criado na Grécia Antiga como referência aos sinais cravados no corpo por corte ou fogo para sinalizar que o portador de tais marcas era escravo, criminoso ou traidor, pessoa a ser evitada. De acordo com o autor, o estereótipo tem sua gênese nas preconcepções que são transformadas em expectativas normativas. Elas nos levam a afirmativas sobre o que o estranho deveria ser, devendo o caráter que imputamos ao outro ser encarado como uma imputação feita por um retrospecto em potencial, o que leva a uma identidade social virtual, em contraponto à identidade social real, soma dos atributos que o outro prova possuir. Tal fato pode levar à constatação da posse de um atributo que o faz diferente dos demais que estão enquadrados em uma categoria na qual poderia ser

\footnotetext{
18 “A relação cognitiva com a realidade externa não é direta, uma vez que se realiza através das imagens mentais construídas individualmente."

19 "Definido o preconceito como a tendência a pensar (e agir) de forma desfavorável frente a um grupo. Podemos agora acrescentar que tal disposição desfavorável se apoia na convicção de que esse grupo ou categoria possui de maneira bastante homogênea as características consideradas negativas. Nesse sentido, como já foi dito, o estereótipo pode ser considerado como o núcleo cognitivo do preconceito.”

20 "pode colocar limites e levantar barreiras artificiais entre as coisas, convertendo-se em um obstáculo para o verdadeiro conhecimento, tanto que até as mentes mais capazes podem cair em sua armadilha". 21 "As tradições na forma de pensar, uma vez consolidadas, tendem a impor suas próprias explicações."
} 
incluído. Com isso, “deixamos de considerá-lo criatura comum e total, reduzindo-o a uma pessoa estragada e diminuída. Tal característica é um estigma, especialmente quando o seu efeito de descrédito é muito grande" (2008, p. 11-12). Segundo Goffmann, é possível mencionar três tipos de estigma. Com exceção do primeiro e mais evidente, "as abominações do corpo, as várias deformidades físicas", os dois outros cercam as maneiras de se enquadrar o Islã no discurso orientalista.

Em segundo, as culpas de caráter individual, percebidas como vontade fraca, paixões tirânicas ou não naturais, crenças falsas e rígidas [...] e comportamento politico radical [...] Finalmente, há os estigmas tribais de raça, nação e religião, que podem ser transmitidos através de linhagem e contaminar por igual todos os membros de uma família (2008, p. 14)

É importante perceber que o termo estigma é utilizado como referência a um atributo profundamente depreciativo, mas o fundamental é uma linguagem de relações e não atributos. Goffman cita o exemplo de um criminoso que se enchia de cuidados para entrar em uma biblioteca pública no bairro onde morava, enquanto tal ato seria avaliado positivamente em um garoto de classe média, como exemplo de que um atributo que estigmatiza pode também servir para normalizar. Da mesma forma, enquanto a prática religiosa ou engajamento político podem ser entendidos como atributos normalizadores em uma comunidade específica, a fé ou militância islâmica podem ser estigmas que fiéis e militantes carregarão como marcas indeléveis em seus corpos. O autor Zachary Karabell identificou a prática ao dizer:

\begin{abstract}
Ask american college students, in the elite universities or elsewhere, what they think of when the word 'Muslim' is mentioned. The response is inevitably the same: gun-toting, bearded, fanatic terrorists hellbent on destroying the great enemy, the United States. (KARABELL apud SAID, 1997, p. xxvi) ${ }^{22}$.
\end{abstract}

Said reconhece que rótulos com o propósito de nomear realidades muito complexas são notoriamente vagos, mas ao mesmo tempo inevitáveis. Ele diz que se é verdade que Islã é um rótulo impreciso e carregado ideologicamente, o mesmo acontece com "Oeste" e "Cristianismo", mas não há uma maneira fácil de evitar esses rótulos, uma vez que todos falam de si mesmos e dos outros de uma maneira que parecem ambos convincentes e exatos. Mas em vez de propor maneiras de passar ao largo dos

\footnotetext{
22 "Pergunte a estudantes universitários americanos, nas universidades de elite ou em outro lugar, o que eles pensam quando a palavra 'muçulmano' é mencionada. A resposta é inevitavelmente a mesma: arma em punho, barbudo, terroristas fanáticos determinados a destruir o grande inimigo, os Estados Unidos."
} 
rótulos, é mais imediatamente prático admitir que eles existem e há tempos são mais usados como parte integral da cultura histórica do que como classificações objetivas. Said argumenta que é preciso lembrar que "Islã", "Oeste”, e "Cristianismo" funcionam em pelo menos dois significados. O primeiro simplesmente para identificar suas funções, como identificar laranjas e maçãs para diferenciá-las. A segunda função é para produzir um significado muito mais complexo. Segundo ele, poucas pessoas sabem exatamente do que estão falando quando usam Islã ou Oeste. E é por isso que devemos levar os rótulos a sério. Para um muçulmano que fala sobre o Oeste ou para um americano que fala sobre o Islã, essas enormes generalizações têm por trás delas toda uma história, capacitando e descapacitando ao mesmo tempo. Ideológicos e usados através de poderosa emoção, os rótulos sobrevivem a muitas experiências e têm sido capazes de adaptação a novos eventos, informações e realidades. No presente, "Islã" e “Oeste”, e não o Cristianismo se contrapõe. Por quê? Por que há uma compreensão de que enquanto o "Oeste" é maior e subjugou o status, o estágio do Cristianismo, sua principal religião, o mundo do Islã está ainda afundado na lama da religião, do primitivismo e do atraso. Assim, o Oeste é moderno, maior que a soma de suas partes, cheio de enriquecedoras contradições e ainda assim Ocidental em sua identidade cultural. O mundo do Islã, por outro lado, nada mais é que o Islã, redutível a uma pequena quantidade de características imutáveis. (SAID, 1997, p.11)

$\mathrm{O}$ orientalismo, que em sua fase moderna passara por uma transformação de uma subespecialidade filológica, até de certa maneira inócua, para uma espécie de instituição com poder político, que emite declarações sobre toda uma civilização e controla colônias, após a Segunda Guerra Mundial dá ao orientalista a faceta de especialista em uma área, do cientista social que aplica sua ciência no Oriente assim como em qualquer outro lugar. $\mathrm{O}$ orientalista se transforma no perito, normalmente a serviço dos negócios e dos governos - e especialmente dos Estados Unidos, país que em definitivo passa a ocupar o centro do palco da política mundial e conserva a questão católica na sua relação com o Oriente, como fizera a Europa. Essa nova relação está calcada no ponto de vista administrativo, mas mantém a atitude de hostilidade cultural e a conserva (SAID, 1990, p. 294-5). 


\section{2 - Orientalismo moderno}

O novo cenário das relações entre o Ocidente e o Oriente encontra a popularização dos meios de comunicação de massa. As considerações e análises feitas especialmente sobre o Islã passam a extrapolar as fronteiras da academia e dos especialistas e especialmente nos momentos de crise - são levadas aos programas de talk show da televisão. A representação do muçulmano no trabalho da imprensa foi analisada por Said em seu livro Covering Islam, lançado em 1981, mas ainda sem tradução no Brasil. Em sua versão revisada, lançada em 1997, defende que nos quinze anos que separam as edições houve um foco intenso nos muçulmanos e no Islã na mídia americana e ocidental, caracterizado especialmente por uma exagerada hostilidade e beligerância já previstas em 1981. O papel do Islã em atos de terrorismo e sequestros de aviões, descrições de como países como o Irã "nos" ameaçam, assim como "nosso" estilo de vida, parecem atuar cada vez mais na consciência ocidental. Parece ter havido também, diz Said, um estranho ressurgimento de ideias canônicas orientalistas sobre os muçulmanos - ideias que alcançaram uma assustadora proeminência em um tempo em que deturpações raciais ou religiosas de todos os demais grupos culturais não mais passam impunes.

Malicious generalizations about Islam have become the last acceptable form of denigration of foreign culture in the West; what is said about the Muslim mind, or character, or religion, or culture as a whole cannot be said in mainstream discussion about Africans, Jews, other Orientals, or Asians (SAID, 1997, p. xii). ${ }^{23}$

\subsection{1 - Choque de civilizações}

As considerações de Said nos levam ao que pode ser considerado o grande marco nas ideias do orientalismo moderno, o artigo "The Clash of Civilizations?", publicado

\footnotetext{
23 “Generalizações maliciosas sobre o Islã se transformaram na última forma aceitável de denegrir uma cultura estrangeira no Ocidente; o que é dito sobre a mente ou o caráter muçulmano, a religião ou a cultura como um todo, não pode ser dito em discussões sobre africanos, judeus, outros orientais ou asiáticos."
} 
originalmente pela revista Foreign Affairs no verão de 1993 e transformado em livro três anos depois com o título The Clash of Civilizations and the Remaking of World Order (HUNTINGTON, 1997). Lançado no Brasil em 1997 - com o título O Choque de Civilizações e a Recomposição da Ordem Mundial -, até hoje ecoa seu ar visionário sobre o que seria uma nova fase do mundo pós-guerra fria. Logo no segundo parágrafo de seu trabalho mais conhecido, Samuel Huntington apresenta sua tese.

\begin{abstract}
Minha hipótese é que a principal fonte do conflito neste novo mundo não será primeiramente ideológica ou econômica. A grande divisão entre a raça humana e fonte dominante do conflito será cultural. Os estados nacionais permanecerão os mais poderesos atores nas relações mundiais, mas os principais conflitos da política global irão ocorrer entre nações e grupos de diferentes civilizações. O choque de civilizações dominará a política global. As linhas falhas entre as civilizações serão as linhas da batalha do futuro. (1993, p. 1).
\end{abstract}

Edward Said analisou as ideias contidas em "O Choque de Civilizações?" em artigo publicado em outubro de 2001 pelo jornal norte-americano The Nation. Em "The Clash of Ignorance", ele diz que o artigo de Huntington se apoia fortemente em "The Roots of Muslim Rage”, publicado por Bernard Lewis três anos antes, e que tanto Huntington quanto Lewis, de maneira imprudente, afirmam a personificação de enormes entidades chamadas "Oeste" e "Islã". Mas rótulos como esses confudem a mente que está tentando estabelecer um sentido em uma realidade desordenada que não será resolvida tão facilmente.

Certainly neither Huntington nor Lewis has much time to spare for the internal dynamics and plurality of every civilization or interpretation of each culture, or for the unattractive possibility that a great deal of demagogy and downright ignorance is involved in presuming to speak for a whole religion or civilization. No, the West is the West, and Islam Islam. (The Nation, 4 de outubro de 2001). ${ }^{24}$

De acordo com Said, as ideias contidas em “O Choque de Civilizações?" estão na raiz de muitas declarações de jornalistas, analistas e políticos, como o italiano Silvio Berlusconi, que, em setembro de 2001, após os atentados nos Estados Unidos, disse que a civilização ocidental é superior à islâmica. Em suas análises sobre o novo cenário

\footnotetext{
${ }^{24}$ Utilizada publicação encontrada no endereço eletrônico < http://www.thenation.com/print/article/clashignorance $>$. "Certamente, nem Huntington nem Lewis têm muito tempo para se dedicar à dinâmica interna e à pluralidade de cada civilização ou interpretação de cada cultura; ou à pouco atrativa possibilidade de que uma grande demagogia e ignorância estão envolvidas ao se presumir falar por toda uma religião ou civilização. Não, o Ocidente é o Ocidente, e o Islã é o Islã”.
} 
introduzido pela globalização no trabalho dos cientistas sociais, Octávio Ianni (1994) já alertava para o enviezamento do pensamento de alguns intelectuais.

Inclusive há aqueles que tomam as sociedades mais desenvolvidas, dominantes ou hegemônicas como parâmetro do que pode ser o mundo. Nestes casos, a globalização tende a ser vista como europeização, americanização ou ocidentalização, ainda que se fale em modernização, secularização, individuação, urbanização, industrialização ou modernidade. (1994, p. 153-4)

Said aponta que Huntington e Lewis usam clara diferenciação entre "nós" e "eles" como pano de fundo de seus argumentos. E é preciso estabelecer que a diferenciação é o processo central através do qual identidade e diferença são produzidas, como nos diz Tomaz Tadeu da Silva (2008). Esse processo está sempre ligado a uma forte separação entre "nós" e "eles", que supõem e ao mesmo tempo afirmam e reafirmam relações de poder. “Os pronomes 'nós' e 'eles' não são, aqui, simples categorias gramaticais, mas evidentes indicadores de posições-de-sujeito fortemente marcadas por relações de poder” (2008, p. 82). De acordo com Said (1997), essas relações de poder se evidenciam na velha visão do Islã como competidor com o Cristianismo Ocidental.

The tendency to consider the whole word as one country's imperium is very much in the ascendancy in today's United States, the last remaining superpower. But whereas most other great cultural groupings appear to have accepted the United States' role, it is only from within the Islamic word that signs of determined resistance are still strong. Therefore we have an efflorescence of cultural and religious attacks on Islam from individuals and groups whose interests are informed with the idea of the West (and the United States, as it leader) as the standard for enlightened modernity. (SAID, 1997, p. xxix). ${ }^{25}$

\subsection{2 - Império}

Michael Hardt e Antonio Negri (2005) analisaram o papel protagonista dos Estados Unidos no que eles chamam de Império. Segundo os autores, esse Império está ligado à globalização de trocas econômicas e culturais com a qual surge uma ordem

\footnotetext{
25 "A tendência de considerar o mundo todo como império de um país está muito no domínio exercido pelos Estados Unidos, a última superpotência remanescente. Mas considerando que a maioria das outras grandes civilizações parecem aceitar o papel norte-americano, é apenas do interior do mundo muçulmano que sinais de uma resistência determinada são fortes ainda. Por isso nós temos uma eflorescência de ataques culturais e religiosos contra o Islã vindos de grupos cujos interesses são instruídos com a ideia do Ocidente (e os Estados Unidos como seu líder) como modelo para a modernidade culta."
} 
global, uma nova lógica e estrutura de comando que representam uma nova forma de supremacia (2005, p. 11). Essa reestruturação do capitalismo significou a vitória de um modelo de autoridade fundado na hegemonia econômica e militar dos Estados Unidos. Hardt e Negri alertam, no entanto, para o fato do Império, em contraste com o imperialismo, não estabelecer um centro territorial de poder e não estar baseado em fronteiras, tendo assim seu poder atuando sem limites geográficos. Esse é o primeiro de três conceitos que definem esse Império. Em segundo lugar vem o conceito de Império como um regime histórico que não nasce da conquista, mas sim como uma ordem que suspende a história e determina, pela eternidade, o estado de coisas existente; não como um momento de transição, mas como um regime sem fronteiras temporais, ou seja, fora da História ou no fim da História. E como um terceiro ponto, o poder do Império funciona em toda a ordem social, profundamente no mundo social, não apenas regulando as interações humanas, mas também regendo a natureza humana, tendo como objeto de governo a vida social como um todo. O Império não apenas administra um território e sua população, mas cria o próprio mundo em que habita.

É importante colocar especial foco no papel reservado aos Estados Unidos nessa configuração, pois eles

[...] não são, e nenhum outro Estado-nação poderia ser, o centro de um novo projeto imperialista. O imperialismo acabou. Nenhum país ocupará a posição de liderança mundial que as avançadas nações europeias um dia ocuparam.

De fato, os Estados Unidos ocupam posição privilegiada no Império, e esse privilégio decorre não de semelhanças com antigas potências imperialistas europeias mas de diferenças em relação a elas. Essas diferenças podem ser reconhecidas mais claramente concentrando-se atenção nos alicerces propriamente imperiais (não imperialistas) da constituição dos Estados Unidos. Entenda-se aqui por constituição tanto a constituição formal, o documento escrito com suas emendas e seu aparelho legal, como também a constituição material, ou seja, a formação e re-formação contínua da composição de forças sociais. Thomas Jefferson, os autores da Federalist, e outros fundadores ideológicos dos Estados Unidos se inspiraram no antigo modelo imperial; acreditavam estar criando do outro lado do Atlântico um novo Império, com fronteiras abertas e em expansão, onde o poder seria distribuído, verdadeiramente, em redes. Essa concepção imperial sobreviveu e amadureceu ao longo da história da constituição dos Estados Unidos, e surgiu agora em escala global, na sua forma plenamente desenvolvida. (HARDT; NEGRI, p. 14-15).

Essa nova relação de forças e os efeitos dessa conjuntura da qual o discurso é uma faceta foram observados por Viviane de Melo Resende e Viviane Ramalho (2006) no livro Análise de discurso crítica. Nos estudos sobre o discurso da imprensa brasileira a 
respeito da invasão estadunidense ao Iraque, as pesquisadoras defendem que uma visão crítica "não deve se furtar à discussão acerca da instauração e sustentação de um tipo de poder hegemônico que pretende [...] desempenhar o papel de guardião do novo capitalismo" (2006, p. 94). Elas apontam as invasões contra o Iraque, em 1991 e 2003, como marcos dessa "nova ordem mundial", o alicerce para o que Hardt e Negri chamam de "uma poderosa função policial contra novos bárbaros e escravos rebeldes que ameaçam sua ordem” (2006,_p. 37). Segundo Resende e Ramalho, esses novos bárbaros e escravos rebeldes são facilmente identificáveis.

[...] são reconhecidamente os movimentos radicais do islã-político, os grupos iraquianos que resistiram à ocupação ou mesmo Saddam Hussein. Para atingir seus objetivos disciplinadores, o poder único usa a força necessária para conduzir, quando julga necessário, "guerras justas" nas fronteiras contra os bárbaros e, no plano interno, contra os rebeldes, a exemplo dos iraquianos, que precisariam ser civilizados e modernizados, o que significa a incorporação do país ao ciclo de produção e acumulação capitalistas. (2006, p. 98).

\subsection{3 - Orientalismo na imprensa}

É importante ressaltar o quão fundamental é o papel da imprensa nesse novo contexto. De acordo com Said, para a maioria dos americanos, e o mesmo é geralmente verdade também para os europeus, a ramificação do aparato cultural que vai levando o Islã para eles inclui em sua maior parte as cadeias de rádio e televisão, os jornais diários e as revistas de notícias. Essa poderosa concentração de mídia de massa constitui um centro de interpretações provendo um retrato do Islã e, claro, refletindo poderosos interesses na sociedade servida pela mídia. E junto com esse retrato, que não é somente um retrato, mas também todo um conjunto de sentimentos sobre o retrato, vai o que se pode chamar de um contexto total, seu lugar na realidade, os valores implícitos nisso e o tipo de atitude que isso promove em quem contempla as reportagens.

Thus, if the Iranian crisis is regularly rendered by television pictures of chanting "Islamic" mobs accompanied by commentary about "antiAmericanism", the distance, unfamiliarity, and threatening quality of the spectacle limit "Islam" to those characteristics; this in turn gives rise to a feeling that something basically unattractive and negative confronts us. Since Islam is "against" us and "out there", the necessity of adopting a 
confrontational response of our own towards it will not be doubted. (SAID, 1997, p. 48.) ${ }^{26}$

Said reconhece a grande variedade de pontos de vista na imprensa. Diz que nós não vivemos à mercê de um aparato centralizado de propaganda, mas lembra que o que a mídia produz não é nem espontâneo e nem completamente livre. Notícias não simplesmente acontecem, as imagens e ideias não se espalham simplesmente da realidade diretamente para nossos olhos e mentes. O processo é sempre mediado. Todos os meios de comunicação observam algumas regras e convenções para que as notícias se tornem inteligíveis. E é isso que molda o material produzido pela imprensa. As empresas de mídia são grupos que também visam ao lucro e compreensivelmente têm interesse em promover algumas imagens da realidade em vez de outras. Eles fazem isso dentro de um contexto político feito por uma ideologia inconsciente, que a mídia dissemina sem séria reserva ou oposição. De acordo com Said, cada repórter americano tem que estar ciente de que seu país é a única superpotência com interesses e meios de satisfazer esses interesses que outros países não têm. Praticamente todo jornalista americano reporta o mundo com a subliminar consciência de que a empresa para a qual trabalha é uma participante do poder americano quando o país é ameaçado por outros países, o que faz a imprensa se subordinar ao que são expressões implícitas como lealdade e patriotismo (1997, p. 48-51).

Quando Said cita o repórter americano, ele está fazendo referência ao jornalismo norte-americano. E nós defendemos neste trabalho que a imprensa brasileira reproduz esse discurso hegemônico encontrado na imprensa norte-americana. Said toca em ponto central para nossa hipótese ao dizer que "like all other residents of the Third World, Muslims tend to be dependent upon a tiny group of news agencies whose job it is to transmit the news back to the Third World" (SAID, 1997, p. 56) ${ }^{27}$.

Levantamento realizado por Isabelle Somma (2007) do material publicado sobre árabes e muçulmanos pelos dois maiores jornais diários do país, Folha de S.Paulo e $O$ Estado de S. Paulo, em período que abrange seis meses antes e seis meses depois do 11

\footnotetext{
26 "Desse modo, se a crise iraniana é apresentada por imagens de multidões islâmicas acompanhadas por comentários sobre o ‘antiamericanismo', a distância, não familiaridade e a qualidade ameaçadora do espetáculo, isso limita o Islã a tais características; e isso dá margem a um sentimento de que algo basicamente não atrativo e negativo nos confronta. Uma vez que o Islã é algo distante e está contra 'nós', não haverá dúvida sobre a necessidade de adotar uma resposta de confronto contra isso."

27 "Como todos os demais residentes no terceiro mundo, muçulmanos tendem a depender de um pequeno grupo de agências de notícias cujo trabalho é transmitir as notícias de volta ao terceiro mundo".
} 
de setembro, mostra o tamanho da dependência dos jornais brasileiros de material produzido pelas agências de notícias internacionais.

Em $O$ Estado de S. Paulo, no período de 11 de março a 9 de abril de 2001, foram creditadas como sendo de uma ou várias agências 108 reportagens, ou 64,28\%. Doze textos da primeira página não tinham crédito, mas se referiam a fatos ocorridos no exterior, o que mostra serem de agências ou veículos estrangeiros. Em segundo lugar dentre as fontes mais usadas estão os jornais e revistas norte-americanos e britânicos, com 19 reportagens, o que soma 11,03\%. A produção da equipe do jornal respondeu por apenas 14 matérias, $8,33 \%$.

Na Folha de S.Paulo, dos 125 textos, 49 foram assinados como "das agências internacionais" (39,2\%), sem especificar quais agências. Outros 40 textos não especificaram como foi feita a apuração, mas, como eram notícias internacionais, é razoável supor que também tiveram origem em serviços noticiosos estrangeiros. Sendo assim, tudo foi somado e resultou em 89 textos escritos a partir de informações de agências internacionais, o que dá 71,2\% . Textos produzidos pela própria redação e reportagem do jornal foram 18 , revistas e jornais estrangeiros, 9 . Se for somada, então, toda a producão de textos vindos de outros meios jornalisticos do exterior, chega-se a 98, ou 78,4\%, mais de três quartos de todo o material publicado (SOMMA, 2007, p. 5659).

No período posterior ao 11 de setembro, foram analisadas 30 edições que vão de 11 de março de 2002 a 9 de abril de 2002.

Nos 30 dias de textos pesquisados em $O$ Estado de S. Paulo, foram encontrados 463 textos que abordaram temas relacionados ao mundo árabe e muçulmano, um aumento de $175,59 \%$ em relação ao recorte anterior, quando foram encontrados 168 textos. As agências de notícias continuaram a ser fonte primária de informação do jornal. Do total de textos, 236 tinham como fonte agências de notícias, o que representa mais da metade $-50,97 \%$. Jornais e revistas norte-americanos e europeus totalizaram 61 textos. Os que não informaram a fonte, mas são notícias do exterior no caderno Internacional, 8. Somados, agências, veículos impressos estrangeiros e os que não mencionam a fonte, mas são notícias certamente tiradas de agências, correspondem a 305, ou $65,87 \%$ do total. Na Folha de S.Paulo, o número de unidades textuais encontradas foi de 411 - 286 a mais que no período anterior, um aumento de 69,58 pontos percentuais. Desse total, 109 textos foram assinados pela "redação com agências internacionais", sendo que no recorte anterior o crédito era dado apenas às "agências 
internacionais". O total de textos produzidos a partir de fontes de informação de outros países, principalmente americanos e ingleses, além de espanhóis, italianos e franceses, foi de 239 , ou $57,42 \%$ do total, número bastante inferior ao resultado do período anterior, em que correspondeu a 78,4\%. A queda se deveu ao envio do jornalista Clóvis Rossi para cobrir a invasão israelense na Cisjordânia (SOMMA, 2007, p. 105-109). De acordo com Somma:

\begin{abstract}
Esses números são importantes para a pesquisa, pois demonstram que em grande medida os jornais paulistanos "importam” informaçoes sobre árabes e muçulmanos de outros meios jornalísticos estrangeiros. Há, portanto, uma intermediação de fontes americanas e europeias decisiva na imagem que os jornais produzem em relação a árabes e muçulmanos. Isso significa que há uma primeira interferência decisiva para a compreensão da apresentaçao que os jornais brasileiros dão a árabes e muçulmanos (2007, p. 58).
\end{abstract}

\title{
1.2.4 - Agências de notícias
}

É preciso levar em conta a história das agências de notícias, especialmente das americanas e europeias, que têm amplo predomínio no jornalismo brasileiro, como mostra a pesquisa de Isabelle Somma (2007). Fernando Reyes Matta (1980) relaciona o legado colonial com o surgimento das agências, em meados do século XIX, ligadas à expansão política e financeira de potências europeias e, desde o começo do século XX, à expansão norte-americana. Tal expansão foi marcada pelo sistema de acordos oficiais entre as grandes agências da época, que dividiam o mundo em zonas de influência. $\mathrm{O}$ primeiro acordo aconteceu na Europa, em 1859, entre as agências Havas, atualmente France Press, Reuter, hoje Reuters, e Wolff, já extinta, passando a incorporar a norteamericana Associated Press em 1875. Um ano antes, com a finalização da instalação do cabo submarino ligando Brasil e Europa, toda América Latina foi colocada na cota dividida entre Reuter e Havas, passando para a Associated Press em fins da Primeira Guerra, quando a agência norte-america estendeu seus tentáculos que, inicialmente, abarcavam apenas o território norte-americano, além de México e Canadá (MATTA, 1980, p. 57-63). A ligação entre o trabalho das agências e os interesses dos países que as sediavam era direta. 


\begin{abstract}
Os serviços da Reuter ao nacionalismo britânico são notórios. Em qualquer parte que a diplomacia britânica tentasse estender seu domínio imperial, Reuter brindava com seu fiel serviço. Reuter não se negou a aceitar os subsídios do governo e das grandes indústrias nacionais. Durante a Guerra Mundial, Reuter era a câmara de compensação da informação mundial, que se tinha elaborado através do moinho purificador da censura britânica. (REIGEL apud MATTA, p. 65).
\end{abstract}

Tal relação entre governos e agências de notícias foi observada também por Kent Cooper, que por mais de 40 anos - quase metade deles como diretor-geral - prestou serviços à Associated Press. Em seu livro Barriers Down, o jornalista diz que

(As agências do cartel) podiam apresentar a informação proveniente de seus próprios países em termos mais favoráveis e sem serem contraditas. Seus países eram sempre glorificados. Logravam seus objetivos levando importantes progressos da civilização inglesa e francesa, cujas vantagens seriam depois, logicamente, outorgadas ao resto do mundo. (COOPER apud MATTA, p. 72).

O último acordo conjunto das quatro grandes agências foi assinado em 1927, mas em 1934 estava já praticamente morto, passando as relações entre agências a ser regidas por contratos bilaterais. E, como aponta Carlos Eduardo Lins e Silva, é a partir da década de 30 que os laços entre Brasil e Estados Unidos começam a se fortalecer, dada a preocupação da administração Roosevelt com a atração do governo Vargas em direção ao nazi-fascismo. Cresce o volume de mensagens produzidas originalmente nos Estados Unidos, como filmes, programas de TV, vídeos, discos, livros, peças teatrais, e o estilo de se fazer cultura de massa, inclusive jornalismo, se aproxima cada vez mais do americano. A partir da década de 50, mas em especial dos anos 70, as elites urbanas passam a exigir que os meios de comunicação locais tenham padrões de qualidade comparáveis aos da sociedade americana, que servia como emuladora da brasileira. As faculdades de jornalismo que se expandiam nesse período passam a ser também fonte de importante disseminação dos valores e técnicas do jornalismo americano nas redações brasileiras. Com rara literatura específica produzida no país, e com fácil acesso aos livros americanos na área, os autores americanos foram os grandes responsáveis pelos textos básicos de formação dos jornalistas no Brasil. Mas a primeira fonte de influência do jornalismo americano sobre o brasileiro são os profissionais daqui que seguem para os Estados Unidos para lá melhor conhecer a prática da profissão. Ao retornarem, começam a usar técnicas ou conceitos que aprenderam ali. (SILVA, 1991). Este foi o 
caso de Roberto Civita, filho mais velho do proprietário da Editora Abril, Victor Civita, que volta ao Brasil em 1958, depois de se formar em Economia e Jornalismo na Universidade da Pensilvânia, e traz na bagagem a ideia de lançar uma revista semanal de informação.

\section{3 - Veja}

Lançada em 11 de setembro de 1968, às vesperas do AI-5, Veja nasceu com a proposta de modernizar a imprensa brasileira tendo como modelo publicações norteamericanas e europeias. Como conta Juliana Gazzotti em Imprensa e ditadura: a revista Veja e os governos militares (1968-85), a revista seria um semanário com especial inspiração em Time e Newsweek (1998, p. 8). Não apenas o projeto gráfico serviria de modelo, mas também material editorial produzido no exterior seria utilizado nas páginas da nova publicação da Editora Abril. Para isso, acordos comerciais foram firmados antes mesmo de Veja chegar às bancas. Segundo Maria Fernanda Lopes Almeida (2009, p. 47), "diariamente, redatores, editores e editores assistentes se debruçavam sobre as revistas semanais de informação: liam e reliam Time e Newsweek. Tentavam repetir a fórmula dessas revistas aqui”. De acordo com Maria Celeste Mira, é impossível falar dos Civita - família fundadora e proprietária da Editoria Abril - sem fazer referência à sua estreita relação com os Estados Unidos. Em sua tese de doutoramento, O leitor e a banca de revistas: o caso da Editora Abril ${ }^{28}$ (1997), ela relata a trajetória de Roberto Civita, responsável pelo lançamento da publicação.

\footnotetext{
Como o pai, ou talvez mais ainda, Roberto - na verdade, Robert - tem uma formação americana. Nascido na Itália, em 1936, ele se muda com a família para Nova York [...] Com os pais e o irmão, Richard, vive na América por dez anos, até que seu pai decide vir para o Brasil em 1949. Morando em São Paulo, os dois irmãos estudam na Escola Americana, na região dos Jardins, após a qual ambos vão continuar sua formação nos Estados Unidos [...] É aceito na Universidade da Pennsylvania [...] Terminado o curso, ele é escolhido para ser estagiário no grupo Time-Life. (2009, p. 115-116).
}

\footnotetext{
${ }^{28}$ Disponível em: <http://cutter.unicamp.br/document/?code=000122361〉.
} 
O jornalismo praticado pelas fontes inspiradoras de Veja foi estudado por Herbert J. Gans (1979) exatamente no período em que a publicação brasileira surgia, na segunda metade da década de 60. Em Deciding What's News - A study of CBS Evening News, NBC Nightly News, Nesweek \& Time o autor descobriu que "foreign news is generally treated with less detachment, and explicit value judgments that would not be considered justifiable in domestic news appear in stories about the rest of the world". ${ }^{29}$ Em sua maior parte, as notícias falavam sobre países europeus, enquanto "other countries typically make the news only when they are the site of unusually dramatic happenings, such as wars, coups d'etat, or major disasters". ${ }^{30}$ Ainda de acordo com o autor, "foreign news adheres less strictly to objectivity than domestic news" (GANS, 1979, p. 31-38) ${ }^{31}$.

Gans afirma com convicção que jornalistas são suscetíveis à pressão de grupos e indivíduos, incluindo fontes e audiência com poder para prejudicá-los, assim como de organizações para as quais trabalham. Ele destaca como importante característica das fontes o fato de providenciarem informações como membros ou representantes de interesses de grupos organizados e não organizados, e ainda grandes setores da nação e da sociedade. Fontes, jornalistas e audiência coexistem em um sistema. Mas esse sistema se estabelece em uma espécie de cabo-de-guerra, e "tugs of war, however, are resolved by power; and news is, among other things, 'the exercise of power over the interpretation of reality", 32 .

O autor diz enxergar as notícias como informações que são transmitidas das fontes para as audiências, com jornalistas - que são funcionários de organizações comerciais burocráticas e membros de uma profissão - sumarizando, refinando e alterando o que se torna disponível para eles a partir de fontes, com o objetivo de fazer a informação adequada para a audiência. As mais importantes características das fontes é que elas providenciam informações como membros ou representantes de interesses de grupos organizados e não organizados, e ainda grandes setores da nação e da sociedade. (1979, p. 81). Jornalistas veem as pessoas principalmente como fontes em potencial, mas fontes se veem como pessoas com a chance de providenciar informações que promovam

\footnotetext{
29 “As notícias internacionais são geralmente tratadas com menos imparcialidade, e valores de julgamento explícitos, que não seriam considerados justificáveis no noticiário doméstico, aparecem em reportagens sobre o resto do mundo".

30 "Outros países aparecem no noticiário apenas quando eles sediam acontecimento dramáticos e pouco comuns, como guerras, golpes de estado ou grandes desastres".

31 "O noticiário internacional adere menos estritamente à objetividade do que o noticiário doméstico".

32 “As notícias que essas agências enviam sempre servem aos seus próprios interesses organizacionais de uma maneira ou outra; os jornalistas podem saber disso, mas, em retorno, eles garantem inicialmente o monopólio em uma estória sensacional”.
} 
seus interesses, para publicar suas ideias. Especial poder têm as fontes ligadas ao governo, pois "the news these agencies supply always serves their organizational selfinterest in one way or another; journalists may know this, but, in return, they initially secure a monopoly on a sensational story". Uma das práticas usuais, utilizadas especialmente em momentos de campanha militar, como a Guerra do Vietnã, foi a chamada "news saturation", que

[...] is the proliferation of so much information by the source that some of it cannot help but turn into news, concurrently placing less well organized sources with more accurate information at disadvantage The Whashington and Saig Pentagons were able to saturate the news media with inflated body counts and successes in winning the hearts and minds of the South Vietnamese population, whereas the anti-war movement lacked the resources to rebut more than a fraction of these reports, even when it had convincing evidence. (GANS, 1979, p. 121) ${ }^{33}$.

Em 2003, o noticiário sobre os ataques norte-americanos contra o Iraque trouxe ao grande público a figura do embedded journalist. No entanto, embora divulgada como novidade, a prática do jornalista embutido entre as tropas assemelha-se às adotadas pelos militares já na Primeira Guerra Mundial, quando a integridade física dos jornalistas que acompanhavam os soldados era protegida pelos militares (ARAUJO NETO, 2005, p. 7-8). Em troca de acesso direto ao campo de batalha, no entanto, os repórteres precisaram aceitar um conjunto de regras de censura militar prévia (CARVALHO, 2004, p. 6). O cenário de extrema proximidade entre jornalistas e suas fontes veio agravar algo já identificado por Gans no trabalho dos chamados beat reporters, os jornalistas que cobrem uma área ou assunto específico, ao contrário dos general reporters, responsáveis pela cobertura de uma gama variada de assuntos. De acordo com o autor:

Beat reporters are somewhat more likely to be co-opted. Some federal
agencies demand agency loyalty from beat reporters; the Pentagon, for
example, has long been known to withhold information from or to banish
reporters who do not adhere to the Pentagon 'line'. In less visible or
controversial agencies, co-optation proceeds almost unconsciously. Beat
reporters become identified with the sources with whom they spend so much
time, and they have little contact with an agency's adversaries. They may not
personally share the political values and objectives of their sources, but they

33 “[...] é a proliferação de um volume tão grande de informações, por parte da fonte, que uma parcela dessas informações em nada ajuda, mas transforma-se em notícias, exercendo uma concorrência que coloca fontes menos organizadas com informações mais corretas em desvantagem. Washington e a agência de notícias do Pentágono foram capazes de saturar o noticiário da mídia com contagem inflada de corpos e tiveram sucesso em conquistar corações e mentes da população do Vietnã do Sul, considerando que o movimento contrário à guerra não tinha recursos para refutar mais do que uma fração dessas reportagens, mesmo quando tinha evidências convincentes". 
accept agency practices and let themselves be used to advance agency objectives, particularly when the result is a dramatic or exclusive story. (GANS, 1979, p. 135) ${ }^{34}$.

O autor concorda com Said - e vai um tanto além - quando ele diz que praticamente todo jornalista americano reporta o mundo com consciência de que a empresa para a qual trabalha é uma participante do poder americano quando o país é ameaçado por outros países, o que faz a imprensa se subordinar ao que são expressões implícitas como lealdade e patriotismo. Segundo Gans,

\begin{abstract}
America is a unit as it deals with other nations, and American citizens or organizations overseas become representatives of that unit when their constitutional rights are threatened. In fact, journalists often follow American foreign policy in selecting foreign news because it supplies a quick and easy importance consideration and because no other equally efficient model is available. (GANS, 1979, p. 149) ${ }^{35}$.
\end{abstract}

Mais de uma análise nos indica que a imprensa norte-americana, através de suas publicações e agências de notícias, apresenta um discurso hegemônico. E nesse discurso encontram-se presentes hostilidade e beligerância perceptíveis num quadro de ressurgimento de ideias canônicas orientalistas sobre os muçulmanos. Compreende-se também que esse processo está sempre ligado a uma forte separação entre "nós" e "eles", que supõe e ao mesmo tempo afirma e reafirma relações de poder que constroem uma visão de mundo que dá suporte a uma poderosa função policial contra aqueles que ameaçam sua ordem. Não se deve perder de vista que a influência do pequeno grupo de agências baseadas nos Estados Unidos, Inglaterra e França é ainda expressiva, sendo a principal fonte de informações da imprensa brasileira. E é especialmente através da visão dos jornalistas dessas agências que as notícias são elaboradas. Ben Bagdikian chama a atenção para o fato de

\footnotetext{
34 “Jornalistas setoristas são mais passíveis de cooptação. Algumas agências federais exigem lealdade desses profissionais especializados em determinado tipo de assunto; o Pentágono, por exemplo, há muito é conhecido por reter informações, ou até mesmo banir os repórteres que não aderem à sua linha. Em agências menos visadas ou controversas, a cooptação acontece quase inconscientemente. Os jornalistas setoristas identificam-se com as fontes com quem passam muito tempo e têm pouco contato com os adversários das agências. Talvez eles não compartilhem dos mesmos valores e objetivos de suas fontes, mas aceitam suas práticas e deixam-se usar para que as agências consigam atingir seus objetivos, particularmente quando o resultado disso é uma história dramática e exclusiva."

35 “América é uma unidade quando lida com outras nações, e cidadãos ou organizações americanos no exterior tornam-se representantes dessa unidade quando seus direitos constitucionais são ameaçados. $\mathrm{Na}$ verdade, jornalistas muito frequentemente seguem a política externa americana ao selecionar notícias internacionais porque isso supre uma rápida e fácil consideração importante e porque não há disponível outro eficiente e igualitário modelo".
} 
[...] os editores norte-americanos e europeus, assim como os principais editores de agências noticiosas mundiais, têm, às vezes, certos estereótipos e preconceitos que devem ser tomados em conta quando os correspondentes ou empregados do escritório transmitem suas notícias à matriz. As notícias que tratam dos aspectos negativos da vida das nações em via de desenvolvimento parecem atrair mais a atenção. Assim, vemos que o pouco espaço dedicado a notícias do Terceiro Mundo refere-se a guerras, golpes de Estado, fome, terrorismo e desorganização (BAGDIKIAN apud HESTER, 1980, p. 90).

Assim, nosso propósito é demonstrar que a revista Veja age, como aponta Edward Said, com interesse em promover algumas imagens da realidade em vez de outras, fazendo isso dentro de um contexto político construído por uma ideologia muitas vezes inconsciente, mas que se renova no âmbito do orientalismo e dissemina-se sem séria reserva ou oposição. Uma vez que mapear e revelar o que o discurso da publicação brasileira diz não daria conta da complexidade de nosso objetivo, sendo necessário não apenas identificar os enunciados e seus possíveis significados, mas também apontar como eles são organizados, as operações que os constroem, além de determinar as condições e estabelecer suas relações com outros enunciados, utilizaremos aqui a Teoria Social do Discurso, abordagem da Análise de Discurso Crítica (ADC) desenvolvida por Norman Fairclough. 


\section{Capítulo II - Análise do Discurso Crítica - Teoria Social do Discurso}

\section{1 - Apresentação}

A Análise do Discurso Crítica (ADC) nasceu no final da década de 1980 como um desenvolvimento programático nos estudos do discurso na Europa. As ideias que resultariam no desenvolvimento da ADC, no entanto, já vinham sendo gestadas desde a década anterior por linguistas da University of East Anglia adeptos da chamada Linguística Crítica, que se voltaram para questões como o uso da linguagem em instituições sociais e a relação entre linguagem, poder e ideologia. Tendo como base a Teoria Sistêmica Funcional, de Michael Halliday, cuja metodologia linguística é saudada como fundamental para as práticas da ADC pelas claras e rigorosas categorias linguísticas para análise das relações entre discurso e significado social, os livros Language as ideology, de Robert Hodge e Gunther Kress, e Language and Control, de Roger Fowler, Tony Trew e os mesmos Robert Hodge e Gunther Kress, ambos de 1979, são consideradas obras seminais para o surgimento da nova vertente da linguística.

Foi Norman Fairclough quem primeiro utilizou o termo Análise do Discurso Crítica, em artigo publicado no Journal of Pragmatics, em 1985. Quatro anos depois, o intelectual inglês lançava o livro considerado como o marco criador da ADC (BLOMMAERT; BULCAEN, 2000, p. 453-454), Language and Power. Nele, Fairclough diz que:

\footnotetext{
A ideologia é mais efetiva quando sua ação é menos visível. Se alguém se torna consciente de que um determinado aspecto do senso comum sustenta desigualdades de poder em detrimento de si próprio, aquele aspecto deixa de ser senso comum e pode perder a potencialidade de sustentar desigualdades de poder, isto é, de funcionar ideologicamente. (FAIRCLOUGH, 1989, p. 85 apud RESENDE; RAMALHO, 2006, p. 22).
}

Reconhecido pela "criação de um método para o estudo do discurso e seu esforço extraordinário para explicar por que cientistas sociais e estudiosos da mídia precisam dos linguistas" (MAGALHÃES, 2005, p. 3), o professor emérito da Lancaster University assistiu à consolidação da Análise do Discurso Crítica como disciplina em 
janeiro de 1991, quando se uniram a ele em um simpósio em Amsterdã os também pesquisadores Teun van Dijk, Theo van Leeuwen, Ruth Wodak e Gunther Kress.

Da Análise do Discurso Crítica deriva a proposta teórico-metodológica de Fairclough chamada Teoria Social do Discurso. Como uma versão da ADC, a TSD "is based upon the assumption that language is an irreducible part of social life, dialectically interconnected with other elements of social life" ${ }^{\text {36 }}$ (FAIRCLOUGH, 2003, p. 2). Tendo como conceitos centrais o discurso e a prática social, o modelo teóricometodológico presta-se à análise de práticas da vida social, podendo mapear as relações entre os recursos linguísticos utilizados por atores sociais e a rede de práticas em que se insere a interação discursiva (RESENDE; RAMALHO, 2006, p. 11-12).

\section{2 - Discurso e prática social}

Para explicar o que chama de práticas sociais, Fairclough (2003) diz que eventos não são de uma maneira simples ou direta os efeitos de estruturas sociais abstratas, uma vez que essa relação é mediada, com entidades organizacionais, entre estruturas e eventos. Elas podem ser vistas como articulações de diferentes tipos de elementos sociais que são associados a áreas particulares da vida social. Exemplos seriam

[...] practices of teaching and practices of management in educational institutions. Social practices can be thought of as ways of controlling the selection of certain structural possibilities and the exclusion of others, and the retention of these selections over the time, in particular areas of social life. Social practices are networked together in particular and shifting ways (2003, p. $23-24)^{37}$

O discurso é visto por Fairclough (2001) em um sentido mais estreito do que o que os cientistas sociais geralmente dão ao se referirem ao uso de linguagem falada ou escrita. $\mathrm{O}$ autor propõe considerar o uso da linguagem como forma de prática social e

\footnotetext{
36 "Baseia-se sobre a presunção que a linguagem é uma parte irredutível da vida social, dialeticamente interconectada com outros elementos da vida social"

37 “...práticas de ensino e práticas de gerenciamento em instituições educacionais. Práticas sociais podem ser pensadas como modos de controlar a seleção de certas possibilidades estruturais e exclusão de outras, além da retenção dessas seleções ao longo do tempo, em áreas particulares da vida social. Práticas sociais são conectadas juntas de maneiras particulares e alternadas".
} 
não como atividade puramente individual ou reflexo de variáveis situacionais (2001, p. 89-90). Ou seja, o discurso é visto como um momento, entre outros, das práticas sociais.

Segundo Viviane de Melo Resende e Viviane Ramalho (2006), para entender o uso da linguagem como prática social é preciso "compreendê-lo como um modo de ação historicamente situado, que tanto é constituído socialmente como também é constitutivo de identidades sociais, relações sociais e sistemas de conhecimento e crença" (RESENDE; RAMALHO, 2006, p. 26-27). De acordo com Fairclough (2001, p. 91), isso "implica uma relação dialética entre o discurso e a estrutura social, existindo mais geralmente tal relação entre a prática social e a estrutura social: a última é tanto uma condição como um efeito da primeira".

Em Discurso e Mudança Social (2001), o autor inglês indica que são três as dimensões que devem ser analisadas no discurso: texto, prática discursiva e prática social, sendo que tanto texto como prática social são descritos como dimensões do evento discursivo mediadas pela prática discursiva:

Figura 1: Dimensões discursivas

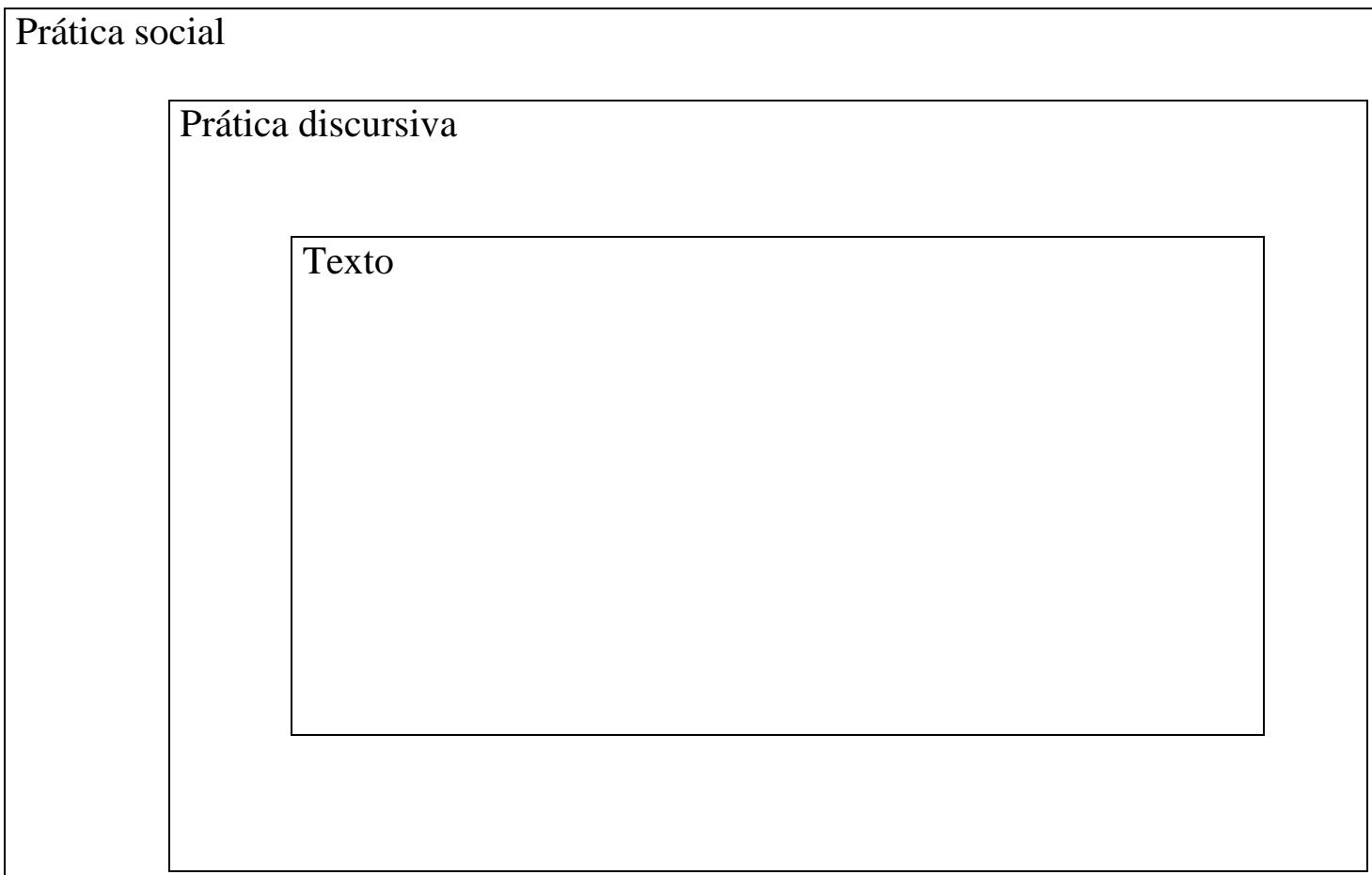


A análise textual pode ser organizada em quatro itens: a) vocabulário, b) gramática, c) coesão e d) estrutura textual, sendo que eles podem ser imaginados em escala ascendente, com o vocabulário relacionado às palavras individuais, a gramática às palavras combinadas em orações e frases, a coesão à ligação entre orações e frases, e a estrutura textual às propriedades organizacionais de larga escala dos textos.

A prática discursiva envolve processos de produção, distribuição, consumo, contexto, força, coerência e intertextualidade, sendo este último o que mais nos interessa, sendo basicamente a propriedade que os textos têm de ser cheios de fragmentos de outros textos, podendo ser demilitados explicitamente ou mesclados. $\mathrm{O}$ autor faz distinção entre intertextualidade manifesta, em que, no texto, se recorre explicitamente a outros textos específicos, e interdiscursividade ou intertextualidade constitutiva.

A prática social envolve o conceito de discurso em relação à ideologia e ao poder, situando esse discurso em uma concepção de poder como hegemonia (FAIRCLOUGH, 2001, p. 101-114).

\section{3 - Discurso, hegemonia e ideologia}

Utilizando-se do conceito de Gramsci anotado em Selections from the prison notebooks (1971), Fairclough diz que:

Hegemonia é liderança tanto quanto dominação nos domínios econômico, político, cultural e ideológico de uma sociedade. Hegemonia é o poder sobre a sociedade como um todo de uma das classes economicamente definidas como fundamentais em alianças com outras forças sociais, mas nunca atingido senão parcialmente e temporariamente, como um "equilíbrio instável". Hegemonia é a construção de alianças e a integração mais do que simplesmente a dominação de classes subalternas, mediante concessões ou meios ideológicos para ganhar seu consentimento. Hegemonia é um foco de constante luta sobre pontos de maior instabilidade entre classes e blocos para construir, manter ou romper alianças e relações de dominação/subordinação que assume formas econômicas, políticas e ideológicas. A luta hegemônica localiza-se em uma frente ampla, que inclui as instituições da sociedade civil 
(educação, sindicatos, família), com possível desigualdade entre diferentes níveis e domínios. (2001, p. 122).

O autor britânico considera ainda que a concepção de luta hegemônica encontrada em Gramsci está em harmonia com sua visão de discurso, ou seja, a concepção dialética da relação entre estruturas e eventos discursivos. A ordem do discurso, explica Fairclough, é a faceta discursiva do equilíbrio contraditório e instável que constitui uma hegemonia, e a articulação e a rearticulação de ordens do discurso são um marco delimitador na luta hegemônica (FAIRCLOUGH, 2001, p.123).

Terry Eagleton (1997, p. 105-108) nos diz que Gramsci utiliza o termo hegemonia para designar a maneira como um poder governante conquista o consentimento dos subjugados ao seu domínio. Ele a associa à arena da sociedade civil, para com isso apontar todo o espectro de instituições que estão em posição intermediária entre o Estado e a economia. Os veículos de comunicação estariam entre esses dispositivos hegemônicos que submetem os indivíduos ao poder antes pelo consentimento que pela coerção. Conquistar a hegemonia, na visão de Gramsci, é estabelecer liderança moral, política e intelectual na vida social. É difundir sua própria visão de mundo pelo tecido da sociedade como um todo. E é preferível que esse poder permaneça invisível e, assim, naturalizado como costume, hábito e prática espontânea.

Eagleton diz ainda que o conceito de hegemonia expande e enriquece a noção de ideologia, e empresta ao termo corpo material e gume político. E é com Gramsci que se efetua a transição crucial de ideologia como sistema de ideias para ideologia como prática social vivida, habitual. Mas não é no filósofo italiano que Fairclough encontra as bases teóricas da ideologia utilizadas na Análise do Discurso Crítica, mas primeiro em Louis Althusser, ainda que considere limitadas as análises do filósofo francês de origem argelina, por conterem uma contradição não resolvida entre uma visão de dominação como imposição unilateral e reprodução de uma ideologia dominante, além da insistência nos aparelhos como local e marco delimitador de uma luta de classe com resultado sempre em equilíbrio.

Além de em Althusser, Fairclough também se apoia no pensamento do inglês John B. Thompson $(2008,2009)$ e suas reflexões sobre ideologia. Para o sociólogo da Cambrigde University, o conceito de ideologia não pode ser despojado de seu sentido negativo e crítico, devendo ser considerada como sentido a serviço do poder. Ele argumenta que ideologia pode ser usada para se referir às maneiras como o sentido, 
entendido como significado, serve, em circunstâncias particulares, para estabelecer e sustentar relações de poder que são sistematicamente assimétricas - chamadas por ele de "relações de dominação". Com isso, diz que:

\begin{abstract}
O estudo da ideologia exige que investiguemos as maneiras como o sentido é construído e usado pelas formas simbólicas de vários tipos, desde as falas linguísticas cotidianas até às imagens e aos textos complexos. Ele exige que investiguemos os contextos sociais dentro dos quais as formas simbólicas são empregadas e articuladas. Ele requer que perguntemos se $-\mathrm{e}$, se este for o caso, como - o sentido é mobilizado pelas formas simbólicas em contextos específicos, para estabelecer e sustentar relações de dominação. A distintividade do estudo da ideologia está na última questão: ele exige que perguntemos se o sentido, construído e usado pelas formas simbólicas, serve ou não para manter relações de poder sistematicamente assimétricas. (THOMPSON, 2009, p. 15-16).
\end{abstract}

Segundo Thompson, há inúmeros modos em que o sentido pode servir para manter relações de dominação. É preciso, então, identificar certos modos de operação gerais da ideologia e indicar algumas das maneiras como eles podem estar ligados, em circunstâncias particulares, com estratégias de construção simbólica. Cinco modos gerais são apontados, com a ressalva de que não são as únicas maneiras de como a ideologia opera e nem sempre independentemente um do outro, podendo sobrepor-se e reforçar-se mutuamente:

- Legitimação, que estabelece e sustenta relações de dominação por serem representadas como legítimas, ou seja, justas e dignas de apoio, podendo basear-se em três estratégias típicas: racionalização, quando o produtor de uma forma simbólica constrói uma cadeia de raciocínio para defender ou justificar um conjunto de relações; universalização, onde acordos institucionais são apresentandos como servindo aos interesses de todos; e narrativização, inseridas em histórias que contam o passado e tratam o presente como parte de uma tradição eterna e aceitável.

- Dissimulação, que estabelece e sustenta relações de dominação sendo ocultada, negada ou obscurecida, tendo como estratégias típicas: o deslocamento, que produz uma recontextualização; a eufemização, quando ações, instituições ou relações sociais são descritas de modo a despertar uma valorização positiva; e tropo, com uso figurativo da linguagem ou, mais comumente, das formas simbólicas, sendo que as formas mais comuns de tropo são a sinédoque, a metonímia e a metáfora. 
- Unificação, que opera a ideologia, permitindo que relações de dominação sejam estabelecidas e sustentadas através da construção de uma forma de unidade interligando indivíduos em uma identidade coletiva, sem levar em conta as diferenças e divisões que possam separá-los. Tem como estratégia típica a padronização, em que as formas simbólicas se adaptam a um padrão, e a simbolização da unidade, que envolve a construção de símbolos de identidade e identificação coletiva.

- Fragmentação, através da qual relações de dominação podem ser mantidas unificando pessoas em uma coletividade, mas segmentando indivíduos e grupos que possam se transformar em desafio real aos grupos dominantes. Tem como estratégia de construção simbólica a diferenciação, dando ênfase às distinções, diferenças e divisões entre pessoas e grupos e apoiando características que os desunem, e o expurgo do outro, que envolve a construção de um inimigo, retratado como mau, perigoso e ameaçador e contra o qual indivíduos são chamados a resistir coletivamente ou a expurgá-lo.

- Reificação, através da qual sustenta-se uma situação transitória e histórica, como permanente, natural e atemporal, utilizando como estratégia a naturalização, em que uma criação social é apresentada como resultado inevitável de características naturais, estratégia semelhante à eternalização, quando fenômenos sócio-históricos são esvaziados de seu caráter histórico ao serem apresentados como permanentes, imutáveis e recorrentes. Há também a nominalização, quando sentenças e descrições de ação são transformadas em nomes, e passivização, quando verbos são colocados na voz passiva (THOMPSON, 2009, p. 82-88)

Para Fairclough (2001, p. 116-119), ideologias são significações/construções da realidade - o mundo físico, as relações e as identidades sociais. Estas são construídas em várias dimensões das formas e sentidos das práticas discursivas e contribuem para a produção, reprodução ou transformação das relações de dominação. Há três importantes asserções sobre ideologia. Primeira, ela tem existência material nas práticas das instituições, o que permite investigar as práticas discursivas como formas materiais de ideologia. Segunda, a ideologia interpela os sujeitos, o que conduz à percepção de que os linguistas ignoram no discurso um dos mais significativos efeitos ideológicos, a constituição dos sujeitos. E, por fim, a asserção de que os aparelhos ideológicos de estado são locais e marcos delimitadores na luta de classes, apontando para a luta no 
discurso e subjacente a ele como foco para uma análise de discurso orientada ideologicamente. De acordo com o autor, questão-chave é identificar se a ideologia é uma propriedade de eventos ou das estruturas. A resposta é: de ambos, tanto nas estruturas (isto é, ordens de discurso) que constituem o resultado de eventos passados, como nas condições para os eventos atuais e nos próprios eventos quando reproduzem e transformam as estruturas condicionadoras.

\section{4 - Discurso na modernidade tardia}

De acordo com Fairclough e Lilie Chouliaraki (1999), a ADC deve situar-se na Ciência Social Crítica e na pesquisa crítica sobre a mudança social na modernidade tardia. O termo late modernity é utilizado por Anthony Giddens $(1991,2002)$ para se referir à atual fase de desenvolvimento das instituições, resultado de transformações socioculturais e econômicas verificadas nas últimas décadas do século XX, quando há uma radicalização no dinamismo da modernidade em três pontos em especial. $\mathrm{O}$ primeiro deles é o que Giddens chama de separação tempo e espaço.

Segundo o autor, todas as culturas tiveram ou têm de lidar com o tempo e com modos de situar-se espacialmente. Em tempos pré-modernos, para a maioria das pessoas e das atividades da vida cotidiana, tempo e espaço mantinham-se ligados pelo lugar. No mundo de hoje, com um sistema de tempo universal e zonas de tempo globalmente padronizadas, a questão é social e experiencialmente diferente de todas as eras prémodernas. Essa separação não significa, alerta Giddens, algo alheio à organização social humana. Ela fornece, pelo contrário, a base para recombinação de maneiras que coordenam as atividades sociais sem necessariamente fazer referência ao lugar:

\footnotetext{
A organização social moderna supõe a coordenação precisa das ações de seres humanos fisicamente distantes; o "quando" dessas ações está diretamente conectado ao "onde", mas não, como em épocas pré-modernas, pela mediação do lugar (GIDENS, 2002, p. 22-23).
}

Giddens alerta para o fato de que a separação entre o tempo e o espaço não deve ser vista como um processo unilinear, uma vez que ela tem traços dialéticos que 
provocam características opostas. Além disso, o rompimento entre tempo e espaço oferece uma base para sua recombinação relacionada à atividade social, tendo como exemplo o horário. O relógio não deve ser visto apenas como um mapa temporal, indicando, por exemplo, o momento da chegada de um trem, mas sim como um dispositivo de ordenação tempo-espaço que indica quando e onde chega o trem (1991, p. 27-28).

O processo de esvaziamento do tempo e do espaço mostra-se fundamental para a compreensão da segunda influência sobre as características da modernidade, o desencaixe das instituições sociais, que são de dois tipos, batizados por Giddens de fichas simbólicas e sistemas especializados, que formam os sistemas abstratos. Fichas simbólicas são os meios de troca com valor padronizado, sendo o dinheiro o melhor exemplo. Elas põem entre parênteses o tempo, por ser um meio de crédito, e o espaço, por permitir transações entre pessoas sem necessidade de contato presencial (GIDDENS, 2002, p. 24). O dinheiro é um modo de adiantamento, proporcionando os meios de conectar crédito e dívida em situações em que é impossível realizar uma troca imediata de produtos. Assim, é possível dizer que o dinheiro é um meio de retardar o tempo e separar as transações de um local particular de troca (1991, p. 32).

\begin{abstract}
O papel do dinheiro está associado à distância espacial entre o indivíduo e sua posse [...] O poder do dinheiro de cobrir distâncias possibilita ao proprietário e à sua posse existirem tão afastados um do outro a ponto de cada um poder seguir seus próprios preceitos numa medida maior do que no período em que o proprietário e suas posses ainda permaneciam num relacionamento mútuo direto, quando todo o engajamento econômico era também um engajamento pessoal (SIMMEL, 1990, p. 332-333 apud GIDDENS, 1991, p. 32)
\end{abstract}

Já os sistemas especializados, ou sistemas peritos, colocam o tempo entre parênteses ao dispor de conhecimento técnico com validade independente dos praticantes e clientes que dele fazem uso.

Tais sistemas penetram em virtualmente todos os aspectos da vida social nas condições de modernidade - em relação aos alimentos que comemos, aos remédios que tomamos, aos prédios que habitamos, às formas de transporte que usamos e muitos outros fenômenos (GIDDENS, 2002, p. 24).

Giddens ressalta que os sistemas abstratos dependem essencialmente da confiança relacionada especificamente à ausência no tempo e no espaço e à ignorância. Isso quer dizer que não precisamos confiar em alguém que está sempre próxima e, portanto, com atividades monitoradas. Também não precisamos de confiança quando entra em cena 
um sistema técnico bastante conhecido. A confiança põe entre parênteses o conhecimento técnico limitado sobre processos que afetam a vida rotineira, como utilizar o transporte aéreo. Nas eras pré-modernas, quando percorriam um longo caminho a pé, os homens dependiam apenas de suas próprias habilidades. Ou de técnicas desenvolvidas por alguém da aldeia na construção de uma carroça, por exemplo, um trabalho feito ao alcance dos olhos.

A modernidade, ressalta Giddens, é, em sua essência, uma ordem pós-tradicional, com a transformação do tempo e do espaço atuando em conjunto com os mecanismos de desencaixe e levando ao afastamento de práticas e preceitos preeestabelecidos. E esse é o contexto da reflexividade. Ela se refere ao fato de a maioria dos aspectos da atividade social e das relações com a natureza serem suscetíveis à revisão a partir de novos conhecimentos, sendo que esse conhecimento não é circunstancial, mas sim constitutivo das instituições modernas (2002, p. 25-26). Nas culturas tradicionais, honra-se o passado e valorizam-se os símbolos, pois eles carregam a experiência das gerações anteriores. É uma maneira de lidar com o tempo e o espaço. Inserem-se atividades e experiências na continuidade do passado, presente e futuro que se estruturam pelas práticas sociais. A tradição não é estática, mas resiste à transformação. Nas eras pré-modernas, a reflexividade limita-se a reinterpretar e esclarecer a tradição. Mas na modernidade ela insere-se na reprodução do sistema e, com isso, a rotina do cotidiano não mantém relação intrínseca com o passado. A tradição continua a desempenhar um papel, mas menos significativo. "Na reflexividade da vida social moderna, as práticas sociais são constantemente reformadas à luz de informação renovadas sobre essas próprias práticas, alterando assim constitutivamente seu caráter" (GIDENS, 1991, p. 44-45).

As propostas de Chouliaraki e Fairclough (1999) têm como objetivo levar a ADC a refletir sobre as mudanças sociais na modernidade tardia. Seguindo o pensamento dos autores, toda análise dentro da ADC inicia-se com: (a) Percepção de um problema que de maneira geral baseia-se em relações de poder, distribuição assimétrica de recursos materiais e simbólicos em práticas sociais, e naturalização de discursos particulares como universais. (b) Identificação dos obstáculos para que o problema seja superado, identificando os elementos de práticas sociais que dão sustentação ao problema e impedem sua mudança estrutural, sendo que três tipos de análise devem agir nesse momento: (1) análise da conjuntura, (2) análise da prática particular e (3) análise do discurso. (c) Função do problema na prática, quando é preciso superar a tão somente 
descrição dos conflitos de poder em que a instância discursiva está envolvida para chegar à avaliação da função nas práticas social e discursiva. (d) Possíveis modos de ultrapassar os obstáculos, tendo como objetivo explorar as possibilidades de superar os problemas identificados. (e) Reflexão sobre a análise, já que toda pesquisa crítica deve apresentar-se como reflexiva (CHOULIARAKI; FAIRCLOUGH, 1999, p. 59-66).

\section{5 - Influências sobre a Análise do Discurso Crítica}

As principais influências sobre a Análise do Discurso Crítica vêm de Mikhail Bakhtin (1992, 1993, 1994, 1997, 2003) e Michel Foucault (1979, 1996, 2009, 2010).

Bakhtin (2003) entendia que há grande confusão em um ponto metodológico fundamental no pensamento linguístico e que isso é resultado do desconhecimento da real unidade da comunicação discursiva: o enunciado. $\mathrm{O}$ autor não deixa dúvidas sobre a importância dessa questão quando diz que o discurso só pode existir de fato na forma de enunciações concretas de determinados falantes, sujeitos do discurso: "O discurso sempre está fundido em forma de enunciado pertencente a um determinado sujeito do discurso, e fora dessa forma não pode existir”. (BAKHTIN, 2003, p. 274). Diz também que:

\footnotetext{
A verdadeira substância da língua não é constituída por um sistema abstrato de formas linguísticas nem pela enunciação monológica isolada, nem pelo ato psicofisiológico de sua produção, mas pelo fenômeno social da interação verbal, realizada através da enunciação ou das enunciações. A interação verbal constitui assim a realidade fundamental da língua. (1992, p. 123).
}

Bakhtin fundou a primeira teoria semiótica de ideologia e foi precursor da crítica do objetivismo abstrato de Ferdinand de Sausurre, sustentando que é um engano separar a língua de seu conteúdo ideológico. Ele diz que as únicas articulações a que os signos linguísticos se submetem ocorrem entre eles próprios apenas e no interior de um sistema fechado. Segundo Bakhtin, o meio social é o centro organizador da atividade linguística; o signo não é mero sinal desvinculado do contexto histórico. 
Enquanto uma forma linguística for apenas um sinal e for percebida pelo receptor somente como tal, ela não terá para ele nenhum valor linguístico. A pura "sinalidade" não existe mesmo nas primeiras das fases da aquisição da linguagem. Até mesmo ali, a forma é orientada pelo contexto, que já constitui um signo, embora o componente da "sinalidade" e de identificação que lhe é correlata seja real. Assim, o elemento que torna a forma linguística um signo não é sua identidade como sinal, mas sua mobilidade específica; da mesma forma que aquilo que constitui a descodificação da forma linguística não é o reconhecimento do sinal, mas a compreensão da palavra no seu sentido particular, isto é, a apreensão da orientação que é conferida à palavra por um contexto e uma situação precisos, uma orientação no sentido da evolução e não do imobilismo (BAKHTIN, 1992, p. 94).

O teórico russo utiliza como exemplo as incorreções encontradas por ele nos estudos da linguística no século XIX. Segundo Bakhtin (2003, p. 270), Wilhelm Humboldt colocava a função comunicativa da linguagem em segundo plano, ainda que não a ignorasse. Ganhava destaque na teoria do alemão a função da linguagem na formação do pensamento. Ele não fazia qualquer menção à necessidade de comunicação entre os homens, sendo a língua uma condição indispensável do pensamento para o homem até mesmo em sua eterna solidão. Já os partidários de Karl Vossler colocavam em primeiro plano a chamada função expressiva, resumida à expressão do mundo individual do falante. Tanto uma quanto outra, subestimariam a função comunicativa da linguagem.

Bakhtin afirma que todos os campos da atividade humana estão ligados ao uso da linguagem e que o caráter e as formas desse uso são tão multiformes quanto os campos de atividade humana. Esses enunciados refletem as condições e finalidades de cada campo da atividade dos seres humanos não só pelo conteúdo temático, mas também pelo estilo, que é a escolha de recursos lexicais, fraseológicos e gramaticais, e, principalmente, pela construção composicional. "E cada campo de utilização da língua elabora seus tipos relativamente estáveis de enunciados, os quais denominaremos gêneros do discurso" (BAKHTIN, 2003, p. 261-262)

Antes de Bakhtin a questão do gênero foi uma preocupação da poética e da retórica. Passou a ocupar papel central na linguística quando ela deixa de trabalhar apenas com textos literários.

Em primeiro lugar, parece que qualquer classificação tem por objetivo pôr uma ordem no caos. Isto é, em meio à heterogeneidade dos textos com que nos defrontamos no campo da linguagem, é necessário identificá-los, organizá-los, ordená-los na tentativa de melhor compreendê-los. Em segundo lugar, porque toda área do saber aspira à cientificidade. Os estudos da linguagem, sobretudo a linguística, aspiram a um status científico e para isso buscam a objetividade, categorizando, classificando seu material de análise. (BRANDÃO, 2000, p. 19-20). 
De acordo com Bakhtin (2003), os gêneros não são estanques e enrijecedores da ação criativa. São eventos textuais altamente maleáveis e dinâmicos. Eles surgem, situam-se e integram-se funcionalmente nas culturas onde se desenvolvem. Estão sempre emparelhados a necessidades e atividades socioculturais, assim como na relação com inovações tecnológicas.

O trabalho de Bakhtin foi também fundamental ao apresentar uma visão dialógica e polifônica da linguagem como contraponto à posição defendida por muitos linguistas da existência de dois pontos na comunicação, o locutor ou o falante - em um papel ativo - e o ouvinte ou entendedor - passivo. De acordo com o autor, essa representação esquemática corresponde apenas a determinados momentos, pois

[...] quando passam ao objetivo real da comunicação discursiva eles se transformam em ficção científica. Neste caso, o ouvinte, ao perceber e compreender o significado (linguístico) do discurso, ocupa simultaneamente em relação a ele uma ativa posição responsiva: concorda ou discorda dele (total ou parcialmente), completa-o, aplica-o, prepara-se para usá-lo, etc. (BAKHTIN, 2003, p. 217).

E o pensamento de Bakhtin apresenta-se como suporte à base da teoria do Orientalismo quando diz que

Em cada época e em todos os campos da vida e da atividade, existem determinadas tradições, expressas e conservadas em vestes verbalizadas: em obras, enunciados, sentenças, etc. Sempre existem essas ou aquelas idéias determinantes dos "senhores do pensamento" de uma época verbalmente expressas, algumas tarefas fundamentais, lemas, etc. [...] Nosso discurso, isso é, todos os nossos enunciados (inclusive as obras citadas), é pleno de palavras dos outros. (BAKHTIN, 2003, p. 294).

De acordo com Viviane de Melo Resende e Viviane Ramalho (2006, p. 18), a visão dialógica e polifônica de vozes que se articulam e debatem a interação é crucial para a abordagem da linguagem como espaço de luta hegemônica de Michel Foucault, uma vez que viabiliza a análise de contradições sociais e lutas pelo poder que levam o sujeito a selecionar determinadas estruturas linguísticas ou determinadas vozes e articulá-las de determinadas maneiras em um conjunto de possibilidades.

Fairclough (2001, p. 63-64) aponta uma grande influência de Foucault sobre as ciências sociais e as humanidades, e atribui a essa influência a popularização do 
conceito de discurso e de análise do discurso. Identifica nos estudos do filósofo francês as duas principais contribuições teóricas sobre o discurso que precisam ser incorporadas à sua abordagem. A primeira, uma visão constitutiva do discurso, no qual ele constitui os objetos de conhecimento, os sujeitos e as formas sociais do "eu", as relações sociais e as estruturas conceituais. Em A Ordem do Discurso, Foucault (1996) diz que, pondo em questão as instãncias de controle, toda tarefa crítica deve

[...] analisar ao mesmo tempo as regularidades discursivas através das quais elas se formam; e toda descrição genealógica deve levar em conta os limites que interferem nas formações reais. Entre o empreendimento crítico e o empreendimento genealógico, a diferença não é tanto de objeto ou de domínio mas, sim, de ponto de ataque, de perspectiva e de delimitação (1996, p. 66-67)

A segunda contribuição téorica aparece em A Arqueologia do Saber, quando Foucault (2010, p. 111) diz que "não há enunciado que, de uma forma ou de outra, não reatualize outros enunciados". Esta é, segundo Fairclough, a ênfase na interdependência das práticas discursivas de uma sociedade ou instituição, onde os textos recorrem a outros textos e os transformam, sendo que qualquer tipo de prática discursiva é gerado através da combinação de outras e definido por suas relações com outras práticas discursivas (FAIRCLOUGH, 2001, p. 63-64).

Vigiar e Punir (FOUCAULT, 2009) também apresenta importante elaboração foucaultiana quando o autor discorre sobre o conjunto de práticas discursivas disciplinadoras de escolas, prisões e hospitais. De acordo com ele, dispensando o uso da força, essas instituições utilizam técnicas de natureza discursiva para fabricar e adestrar indivíduos com o intuito de encaixá-los nas necessidades do poder. Para Foucault, essa prática acontece com "técnicas sempre minuciosas, muitas vezes íntimas, mas que têm sua importância: porque definem um certo modo de investimento político e detalhado do corpo, uma nova 'microfísica' do poder'. (2009, p. 134).

\section{6 - Paradigma funcionalista e Linguística Sistêmica Funcional}

$\mathrm{O}$ foco da $\mathrm{ADC}$ não se limita à interioridade dos sistemas linguísticos. Seu interesse está voltado à investigação de como esses sistemas funcionam representando eventos, construindo relações sociais, estruturando, reafirmando e contestando hegemonias. Dessa maneira, a ADC entende ser a abordagem funcionalista a única 
aplicável à análise do discurso, uma vez que enxerga a linguagem como um objeto não suficiente em si, mas sim como objetivo que tem

[...] funções externas ao sistema, que são a parte central dos estudos linguísticos-discursivos, e essas funções externas são responsáveis pela organização interna do sistema linguístico (SCHIFFRIN, 1994 apud RESENDE; RAMALHO, 2006, p. 12)

Ou seja, a Linguística Sistêmica Funcional (LSF), de Halliday, utilizada por Fairclough como base para sua Teoria Social do Discurso, aborda a linguagem através de uma visão dialética que percebe textos não apenas como estruturados pelo sistema, mas também inovadores desse sistema.

Para Halliday (HALLIDAY, 1985, p. 56), a relação entre as funções sociais da linguagem e a organização do sistema linguístico é um traço geral da linguagem humana e, por isso, é preciso estudar os sistemas internos das línguas naturais sob a perspectiva das funções sociais. Com isso, o autor apontou três macrofunções que, de acordo com ele, simultaneamente atuam nos textos: ideacional, que representa a experiência, uma vez que os enunciados remetem a eventos e ações da atividade humana; interpessoal, referindo-se ao significado do ponto de vista de sua função no processo de interação social, expressando relações sociais e pessoais; e textual, onde se apresentam os aspectos semânticos, gramaticais e estruturais que devem ser analisados no texto.

Mas, para seus propósitos de análise, em Discurso e Mudança Social (2001, edição em inglês 1992), Fairclough recontextualiza o modelo proposto por Halliday, sugerindo que a função interpessoal seja separada entre as funções identitária e relacional. Uma década mais tarde, em Analysing Discourse (2003), Fairclough vai um tanto mais além e estabelece para o lugar das funções da linguagem três tipos principais de significado: acional, representacional e identificacional.

I shall also view texts as multi-functional in this sort of sense, though in a rather different way, in accordance with the distinction between genres, discourses and styles as the three mains ways in which discourse figures as a part of social practice - ways of acting, ways of representing, ways of being. Or to put it differently: the relationship of the text to the event, to the wider physical and social world, and to the persons involved in the event. However, I prefer to talk about three major types of meaning, rather than functions: Action, Representation, Identification. (FAIRCLOUGH, 2003, p. 27) ${ }^{38}$

\footnotetext{
38 “Eu devo também ver os textos como multifuncionais nesse tipo de sentido, ainda que de uma maneira diferente, de acordo com as distinções entre gêneros, discursos e estilos como as três principais maneiras nas quais o discurso figura como parte das práticas sociais - maneiras de agir, de representar e ser. Ou para colocar isso de maneira diferente: a relação do texto com o evento, com um mundo social e material
} 
É sob a perspectiva dos significados estabelecidos por Fairclough que analisaremos nosso objeto de pesquisa.

mais amplo, e com as pessoas envolvidas no evento. Entretando, eu prefiro falar sobre três tipos principais de significado em vez de funções: ação, representação e identificação." 


\section{Capítulo III - Análise qualitativa: O discurso jornalístico como ação e identificação}

\section{1 - Categorias de análise}

A proposta deste trabalho é demonstrar que Veja reproduz o discurso hegemônico norte-americano no que diz respeito aos muçulmanos, contribuindo para a construção e a manutenção de uma identidade negativa dos que professam sua fé na religão islâmica, não oferecendo aos seus leitores uma pluralidade de opiniões acerca das questões que envolvem as pessoas desta religião, além de limitar e, na maioria dos casos, deixar de fora posições que se apresentam como contrárias às defendidas pelo governo dos Estados Unidos. Como já explicitado na introdução deste trabalho, temos como objetivo não apenas identificar os enunciados, mas apontar como eles são organizados e compreendê-los na estreiteza e singularidade de sua situação, determinando as condições de sua situação, como diz Michel Foucault (2010), além de estabelecer suas relações com outros enunciados. Uma vez que o próprio filósofo francês também diz considerar "fora de cogitação [...] o fato de se poder descrever, sem limites, todas as relações que possam, assim, aparecer” (2010, p. 33), para demonstrar tais ocorrências, utilizaremos duas categorias de análise: intertextualidade, apontada dentro do significado acional, e avaliações, no significado identificacional.

\subsection{1 - Intertextualidade}

De acordo com Bakhtin (2003, p. 297), "nosso discurso, isto é, todos os nossos enunciados [...] é pleno de palavras dos outros [...] é pleno de ecos e ressonâncias de outros enunciados com os quais está ligado pela identidade da esfera de comunicação discursiva.". Fairclough (2003) considera a análise dessa intertextualidade ponto 
fundamental da ADC. Mas a amplia para além do discurso direto (identificado entre parênteses, como em "Ela disse, "chegarei atrasada") e indireto ("ela disse que chegará atrasada"), ressaltando a importância do estudo das assumptions, que chamamos aqui de pressuposições, como na linguística pragmática, que são enunciados alheios implícitos nos textos. Segundo Fairclough:

Texts inevitably make assumptions [...] As with intertextuality, assumptions connect one text to other texts, to the "world of texts" as one might put it. The difference between assumptions and intertextuality is that the former are not generally attributed or attributable to specific texts. It is a matter rather of a relation between this text and what has been said or written or thought elsewhere, whit the "elsewhere" left vague. (2003, p. 40). ${ }^{39}$

A análise deve orientar-se tendo como referência a abertura ou o fechamento da diferença. De acordo com a ADC, enquanto a intertextualidade apresenta abertura para a diferença, a pressuposição reduz. A opção mais dialógica é a atribuição explícita a outras vozes que estão no texto, ou seja, os discursos diretos e indiretos. A opção menos dialógica anula a diferença entre a voz do locutor e a voz externa, que é recontextualizada, indicando alto engajamento com o que se enuncia. Ou seja, a intertextualidade pode sinalizar para a abertura e explicitação da diferença; a pressuposição indica a normalização e a aceitação, camuflando as diferenças de poder. Ambas relacionam-se a enunciados de outros textos, mas no caso da pressuposição esse outro lugar não aparece de maneira clara e passa a representar a voz do próprio autor do texto. Com isso, a análise das pressuposições serve para desvendar posições ideológicas naturalizadas no discurso (RAMALHO, 2005, p. 94-95).

Nosso trabalho analisará a intertextualidade através do discurso direto, que segundo Fairclough (2003, p. 49) é "quotation, purportedly the actual words used, in quotations marks, with a reporting clause" ${ }^{40}$, e discurso indireto, como "the content of what was said or written, not the actual words used, no quotation marks, with a reporting clause" ${ }^{41}$. Também analisará pressuposições existenciais, "assumptions about what exists" 42 .

\footnotetext{
39 “Textos inevitavelmente fazem suposições. [...] Assim como com a intertextualidade, pressuposições conectam um texto ao outro, ou ao mundo dos textos. A diferença entre pressuposições e intertextualidade é que a primeira geralmente não é atribuída ou atribuível a textos específicos. Essa é uma questão mais propriamente da relação entre este texto e o que foi dito, escrito ou pensado em outro lugar, com esse 'outro lugar' deixado de maneira vaga."

40 “citação, supostamente da palavra usada de fato, entre aspas numa sentença noticiosa"

41 “o conteúdo do que foi dito ou escrito, não as palavras realmente usadas, não as palavras entre aspas, numa sentença noticiosa."

42 "pressuposições sobre o que existe"
} 


\subsection{2 - Avaliações}

A avaliação está relacionada à maneira como os autores se comprometem com o que é considerado desejável ou indesejável, bom ou ruim. A maneira como as pessoas se comprometem através de textos é parte substancial da maneira como se identificam (RAMALHO, 2005, p. 133). Para nossos propósitos, achamos acertado utilizar dois tipos de realização na categoria avaliação: afirmações avaliativas e presunções valorativas. Segundo Fairclough (2003, p. 172-173), afirmações avaliativas são "statements about desirability and undesirability, what is good and what is bad (and) also evaluate in terms of importance, usefulness and so forth [...] where desirability is assumed" ${ }^{43}$. Presunções valorativas são para casos "without the relatively transparent markers of evaluation [...] where values are often much more deeply embedded in texts" 44 .

\footnotetext{
43 “afirmações sobre o que é desejável ou indesejável, o que é bom ou o que é ruim (e) avaliação em termos de importância, utilidade e assim por diante [...] onde o que é desejável é assumido"

44 “Sem as relativamente transparentes marcas de avaliação [...] onde os valores se encontram embutidos muito mais profundamente nos textos"
} 


\section{2 - Análise corpus pré-11 de setembro}

Texto 1: Reportagem revista Veja edição 1666 - 13 de setembro de 2000.

\section{Turistas alegres são barrados no porto}

O turismo é uma das principais fontes de receita da Turquia e o país de maioria muçulmana está acostumado a todo tipo de turista. Ainda assim, as autoridades entraram em surto com a chegada de um cruzeiro de homossexuais. Na semana passada, eles foram impedidos de descer do navio no porto de Kusadasi. A proibição pegou mal e as autoridades voltaram atrás, liberando a entrada dos alegres visitantes e pedindo desculpa pela mancada.

Tabela 1: Reportagem revista Veja edição 1666 - 13 de setembro de 2000.

\begin{tabular}{|l|l|}
\hline Discurso direto & \\
\hline Discurso indireto & $\begin{array}{l}\text { - as autoridades entraram em surto com a } \\
\text { chegada de um cruzeiro de homossexuais }\end{array}$ \\
\hline Pressuposições existenciais & $-\underline{\text { Turistas alegres são barrados no porto }}$ \\
\hline $\begin{array}{l}\text { Afirmações avaliativas/presunções } \\
\text { valorativas }\end{array}$ & - liberando a entrada dos alegres visitantes \\
& - A proibição pegou mal \\
& - Pedindo desculpa pela mancada \\
\hline & \\
\hline
\end{tabular}


Como indica a Tabela 1, o texto publicado por Veja não faz atribuição explícita a manifestação de qualquer personagem envolvido no contexto dos acontecimentos registrados na Turquia. Não há qualquer registro de discurso direto ou indireto, apenas de pressuposições, notadamente a de que as autoridades entraram em surto, e a afirmação avaliativa de que a proibição pegou mal. Tal situação indica uma posição de fechamento para a diferença, anulando a diferença entre a voz do locutor e a voz externa que nele é recontextualizada, pois pegar mal indica que tal postura - não o ato da proibição em si, mas todo o contexto da proibição e posterior liberação - foi reprovada. Como certamente a reprovação não adveio da totalidade de opiniões, a afirmação representa um ponto de vista não explicitado no texto, ou seja, internalizado como voz do próprio locutor. A revista fez questão de apontar a Turquia como um país de maioria muçulmana. Devemos aqui relembrar o pensamento do professor Tomaz Tadeu da Silva (2008), que nos aponta que a identidade parece ser uma positividade, tendo como referência a si própria, sendo autocontida e autossuficiente, e com a mesma linha de raciocínio podemos pensar também a diferença apenas como oposição à identidade. No entanto, é preciso compreender que identidade e diferença estão em uma relação de estreita dependência, além de ter em conta que a afirmação da identidade e a enunciação da diferença traduzem o desejo de diferentes grupos sociais, assimetricamente situados, de garantir o acesso privilegiado aos bens sociais, estando em estreita conexão com relações de poder. $\mathrm{O}$ poder de definir a identidade e assentar a diferença não está apartado das relações mais amplas de poder. Segundo Tomaz da Silva $(2008$, p. 82$)$, a diferenciação é o processo central pelo qual a identidade e a diferença são produzidas, mas há uma série de outros processos que traduzem essa diferenciação: induzir/excluir (esses pertencem, aqueles não); demarcar fronteiras (nós e eles); classificar (bons e maus, puros e impuros, desenvolvidos e primitivos, racionais e irracionais); normalizar (nós somos normais, eles são anormais). Chama a atenção também a maneira como a revista atribui um estereótipo aos turistas homossexuais, indicados no texto como turistas alegres e alegres visitantes. Se em uma observação mais superficial o adjetivo alegre pode parecer inofensivo, a análise mais detalhada em um dicionário também vai nos trazer como sinônimos para alegre os significados "um tanto livre ou desonesto; ligeiramente bêbado; picante" ${ }^{45}$. Isso nos leva à questão colocada por Fairclough (2003, p. 40) quando diz que "what is 'said' in a text is 'said'

\footnotetext{
${ }^{45}$ Disponível em: <http://michaelis.uol.com.br/moderno/portugues/index.php?lingua=portuguesportugues\&palavra=alegre $>$.
} 
against a background of what is 'unsaid', but taken as given" ${ }^{46}$. É interessante ainda estabelecer uma comparação entre a cobertura realizada por Veja e pela imprensa norteamericana e europeia, de onde a revista brasileira retirou as informações utilizadas em seu texto. The New York Times, dos Estados Unidos, e The Guardian, da Inglaterra, noticiaram o fato em 7 e 8 de setembro de 2000, respectivamente. A cobertura é bastante diferente da realizada por Veja, como mostram os textos publicados a seguir. Enquanto a publicação brasileira não apresenta qualquer discurso direto ou indireto de qualquer personagem envolvido nos acontecimentos, o The New York Times registra diretamente o posicionamento de três autoridades, uma norte-americana e duas turcas. O The Guardian foi ainda além e citou diretamente as palavras do ministro do Turismo da Turquia, de um comericante local, e de um turista barrado pela polícia, além de registrar indiretamente a manifestação de um dos organizadores da viagem e do ministro do Interior da Turquia. Em nenhum momento, qualquer um dos jornais diários mencionou o fato da Turquia ser um país de maioria muçulmana, e nenhum adjetivo foi utilizado para caracterizar os passageiros da viagem de turismo. Enquanto Veja escolheu "turistas alegres" e "alegres visitantes", o The New York Times escolheu "gay Americans", "Americans", "tourists”, "passengers", "gay tourists”; o The Guardian utilizou "gay tourists", "gay men", "men" e "tourists".

\footnotetext{
46 “o que é dito em um texto é dito contra um segundo plano do que não é dito, mas assumido como um fato dado"
} 


\section{Turkish Police Bar Gay Americans From Visiting}

Aegean Port - Reportagem The New York Times - 7 de setembro de 2000

\section{By CHRISTOPHER MARQUIS}

WASHINGTON, Sept. 6 - The Turkish police barred several hundred gay Americans today from visiting tourist sites near an Aegean port, Kusadasi, and ordered them back aboard their cruise ship, prompting complaints from the State Department, officials said.

Most of the tourists, who are on what travel operators say is the largest gay cruise to visit Turkey, were rounded up from locations ashore, ordered to board their buses and escorted by the police back to the ship, according to State Department and White House officials, as well as people who spoke with passengers.

Other passengers were prevented from leaving the area where their ship, the Olympic Voyager, was docked. About 800 gay tourists are on the cruise.

American diplomats protested to the Turkish Foreign Ministry and raised the concern that the Americans were being mistreated because of their sexual orientation.

"We asked that the tourists be allowed to continue their tour of Turkey unencumbered," said Philip Reeker, a spokesman for the State Department.

Although Mr. Reeker said the facts surrounding the incident were sketchy, he confirmed the police actions. "Obviously," he said, "we're dismayed at the actions. That's why we contacted the Turkish officials."

The tour operator decided to continue the cruise, which is scheduled to reach Istanbul on Thursday. The State Department has asked the American consul general to meet the travelers and to help ensure that there are no further problems, Mr. Reeker said.

A spokeswoman for the Turkish Embassy in Washington, Sensu Yemisci, said she did not have specific information about the incident. But she disputed a suggestion that Turks were not tolerant of gays and noted that the beach resort of Bodrum, not far from Kusadasi, also near Samos, was popular among homosexual tourists. She called the allegations of police bias absurd.

"There are hundreds of thousands of gays in Turkey," Ms. Yemisci said. "Probably, ordinary people don't like it very much. But it doesn't make any difference." 
David Mixner, a gay Democratic Party campaigner who spoke by telephone with the tour organizer in Turkey, said the Turkish police had told the tourists that they were not allowed ashore because of their homosexuality. Mr. Mixner said he spoke with Rich Campbell of Atlantis Events, the operator, which has its headquarters in Los Angeles.

"They were not allowed off the ship because they were gay," Mr. Mixner said. "This was not a secret. There was no issue other than that. There was no inappropriate behavior or confrontation. They were tourists."

The weeklong luxury cruise was to include stops to see the Parthenon in Greece, the Pyramids in Egypt and Israeli holy sites. In promotional material, Atlantis, the largest American tour operator that caters to gays, described the trip as "unlike any Atlantis has ever offered."

The incident was the third time that Atlantis has faced a significant confrontation abroad.

In 1998, the Cayman Islands, a Caribbean destination renowned for its scuba diving, notified Atlantis that it would not allow its cruise ship to dock. The tour was rerouted to Belize.

Also that year, members of an Atlantis group faced small public protests in Costa Rica. Government officials subsequently apologized, Atlantis officials said.

\section{Turkish police block gay tour from Roman ruins - Reportagem}

The Guardian - 8 de setembro de 2000

Chris Morris in Ankara

Turkey's tourism minister apologised yesterday after hundreds of gay tourists were prevented by local police from entering the coastal town of Kusadasi and the nearby Roman ruins at Ephesus.

"I hope they will complete their trip without any problems," the minister, Erkan Mumcu, said. "We cannot discriminate according to people's sexual preference."

The group of 833 gay men, including a number of Britons, arrived in Turkey on Wednesday on the cruise liner Olympic Voyager on its way from Israel. 
Several bus loads of men on their way to the spectacular ruins at Ephesus were turned back by the police. Others were prevented from entering the town of Kusadasi to go shopping.

"When we got back, a guy from the ship just said: 'Get on the ship as fast as you can,' " Ken Damon from Tucson, Arizona said. "We were going to spend two weeks in Kusadasi, but we don't want to be in a country that doesn't respect us."

Local people, including the mayor, were also quick to apologise. "This is against human rights," Haci Kahveci, a local tradesman said. "If it happens again we'll take action. It shouldn't be tolerated."

Most of the gay tourists were from the United States. The US embassy contacted Turkish authorities to demand that the Americans be allowed to travel freely. By then, however, the damage had been done.

One of the organisers of the tour, Jonathan Evrin, said they had visited Turkey last year without encountering any problems, and he was at a loss to explain the sudden change in attitude.

Homosexuality is not technically illegal in Turkey, but officials said yesterday that there was a clause in the passport law which could allow the authorities to prevent gays entering the country. The local gay community complains of constant discrimination, even though many gay singers are very popular.

Yesterday the tourists moved on to Istanbul, where they were shadowed by a heavy police presence. Riot police and motorcycle outriders accompanied the tourist buses as they visited some of the city's best known sites.

The interior minister had issued a personal guarantee that the tourists would be safe, but there are red faces in the bureaucracy over an incident which has not done much for Turkey's image as a hospitable tourist destination. 
Texto 2 - Reportagem revista Veja edição 1667 - 20 de setembro de 2000.

\section{O PIOR LUGAR DO MUNDO}

Ingleses destroem milícia em Serra Leoa, país onde a guerrilha corta a mão de crianças

A Inglaterra perdeu a paciência e, na semana passada, mandou um pelotão resgatar onze de seus soldados seqüestrados por uma milícia de Serra Leoa, os West Side Boys. No domingo 10, 110 pára-quedistas de sua majestade libertaram os reféns, que fazem parte das forças de paz da ONU, mataram pelo menos 25 seqüestradores e capturaram o chefe, Foday Kallay. Os West Side Boys, com seu estapafúrdio nome de banda de rock, são os típicos combatentes de uma guerra cujas atrocidades conseguem ser mais chocantes que qualquer outra das barbaridades em curso na África. As tropas são formadas por adolescentes movidos a drogas cujo mais abominável hábito é cortar as mãos de civis escolhidos a esmo, inclusive mulheres e crianças. Kallay apresentava-se nas negociações para a libertação dos ingleses como "general-de-brigada", mas, até que o país mergulhasse no banho de sangue, ele era apenas o porteiro do Ministério da Defesa. Só neste ano, os grupos armados seqüestraram mais de 700 soldados e funcionários das forças de paz da ONU, que tentam impor um pouco de lucidez no desvario de uma guerra cujo único objetivo é ver quem vai roubar maior quantidade de diamantes, a única riqueza do país.

O garimpo de diamantes não é apenas o melhor negócio, mas também a única mercadoria de valor de Serra Leoa. Impressiona como tal riqueza acabou levando o país a se tornar o pior lugar do mundo. Serra Leoa foi criada em 1787 para ser uma colônia e receber escravos emancipados pelos ingleses após a independência dos Estados Unidos. Mas só despertou o interesse dos europeus quando o mineral foi descoberto, em 1930. Até 1963, dois anos após sua independência, apenas os brancos exploravam a pedra. Desde que as minas foram nacionalizadas, não houve mais paz. Metade dos habitantes já perdeu suas casas e o país despencou para o último posto no índice de desenvolvimento humano da ONU. Sua renda per capita de 130 dólares é uma das mais baixas do mundo e $70 \%$ da população está desempregada e vive abaixo da linha de pobreza. Sete em cada dez adultos são analfabetos e a expectativa de vida de 35 anos é a mais baixa do planeta. Serra Leoa é a campeã mundial em mortalidade 
infantil, com 170 mortes a cada 1000 nascimentos. O banco central, os serviços públicos essenciais, a polícia e os últimos resquícios de um Estado organizado desapareceram.

A guerra começou há quase uma década. O grande vilão é um contrabandista de diamante chamado Foday Sankoh. Ele foi cabo no Exército, passou sete anos na cadeia por conspiração nos anos 70 e outros tantos treinando guerrilha na Líbia. No início da década, entrou no país com um bando de guerrilheiros esfarrapados. Apesar da tropa mambembe, não foi difícil derrotar o Exército nacional. Com um efetivo mínimo, desorganizado e mal equipado, o Exército leal ao governo debandou. Em 1995, para evitar a derrota, a solução encontrada foi pagar 35 milhões de dólares a uma firma de mercenários da África do Sul. Pouco mais de 200 homens bem treinados e equipados com helicópteros foram capazes de expulsar a guerrilha de Sankoh de volta para o interior do país. No ano seguinte foi eleito um presidente, Ahmad Tehan Kabbah. Não demorou para que a soldadesca se amotinasse devido ao atraso nos soldos. Os amotinados libertaram os guerrilheiros presos e convidaram Foday a fazer parte de um novo governo. A intervenção de uma força de paz africana repôs Kabbah no palácio, que mandou fuzilar 24 oficiais e condenou Foday à morte. Antes de sua execução, uma coligação de desertores e guerrilheiros atacou Freetown, a capital do país. Foi então que se espalhou o terror para valer. Moradores de bairros inteiros eram reunidos por guerrilheiros adolescentes e metralhados nas ruas ou queimados vivos em suas casas. Esquadrões especiais, na maioria formados por crianças, circulavam com facões e machados mutilando as pessoas. Gostavam de perguntar às vítimas se preferiam "manga curta ou longa". Significava perder a mão ou todo o membro. O objetivo era aterrorizar a população e estima-se que 100000 foram mutilados. Sankoh foi capturado pelo governo no início deste ano e não se sabe com certeza se está preso ou morto. Não existe outro motivo convencional para que as pessoas se matem por lá exceto, evidentemente, os diamantes. Não há diferenças tribais significativas nem conflitos ideológicos. Mas o que era para ser a salvação do país acabou se tornando a razão de sua miséria e já matou mais de 50000 pessoas em nove anos de guerra civil. Serra Leoa tem capacidade para extrair 70 milhões de dólares por ano de diamantes, contudo apenas 1,5 milhões de dólares constam da receita oficial. O resto é contrabandeado para os países vizinhos em troca de armas que incendeiam a guerra. A ONU vem estudando uma forma de embargo a esses diamantes, mas a tarefa é quase 
impossível. Contrabandeá-los é muito fácil, uma vez que poucas pedras formam uma grande fortuna facilmente transportada numa caixa de fósforos. Vale tudo para esconder as pedras. Engolir, colocar debaixo da língua ou das unhas. Os traficantes de Serra Leoa são capazes até mesmo de ocultá-las na pele, colocando-as em machucados abertos e recém-cicatrizados. A ousadia dos contrabandistas é a mesma dos assassinos na hora de decidir quem vai morrer. As vítimas podem ser pessoas que se recusam a lhes dar dinheiro ou simplesmente qualquer um com quem não simpatizam. Os facínoras estupram mulheres e freiras, seqüestram padres, marcam crianças como gado e as drogam para obrigá-las a guerrear. O governo conta com a ajuda de uma milícia igualmente brutal, a Kamajor. Caçadores tribais, eles costumam freqüentar o campo de batalha protegidos com amuletos que, acreditam, os tornam imunes às balas. Os guerrilheiros e milicianos de Serra Leoa formam uma curiosa caricatura de elementos primitivos e da cultura pop internacional. Vestem camisetas de bandas de rock, misturam óculos escuros com perucas vermelhas. Querem ser chamados por apelidos, como "Coronel Sanguinário", "Comandante Cortador de Mãos" ou "Mister Morte". Nomes que soam bem no pior lugar do mundo.

Tabela 2: Reportagem revista Veja edição 1667 - 20 de setembro de 2000.

\begin{tabular}{|c|c|}
\hline Discurso direto & \\
\hline Discurso indireto & \\
\hline Pressuposições existenciais & $\begin{array}{l}\text { - A Inglaterra perdeu a paciência } \\
\text { - único objetivo é ver quem vai roubar } \\
\underline{\text { maior quantidade de diamantes }} \\
\text { - O grande vilão é um contrabandista de } \\
\text { diamante chamado Foday Sankoh }\end{array}$ \\
\hline $\begin{array}{l}\text { Afirmações avaliativas/presunções } \\
\text { valorativas }\end{array}$ & $\begin{array}{l}\text { - Os West Side Boys, com seu } \\
\text { estapafúrdio nome de banda de rock } \\
\text { - um bando de guerrilheiros esfarrapados } \\
\text { - Apesar da tropa mambembe, não foi } \\
\text { difícil derrotar o Exército nacional } \\
\text { - Os guerrilheiros e milicianos de Serra } \\
\text { Leoa formam uma curiosa caricatura de }\end{array}$ \\
\hline
\end{tabular}




\begin{tabular}{|l|l|}
\hline & $\begin{array}{l}\text { elementos primitivos e da cultura pop } \\
\text { internacional } \\
\text { - O pior lugar do mundo } \\
\text { - Impressiona como tal riqueza acabou } \\
\text { levando o país a se tornar o pior lugar do } \\
\text { mundo }\end{array}$ \\
\hline & $\begin{array}{l}\text { - Nomes que soam bem no pior lugar do } \\
\text { mundo }\end{array}$ \\
\hline & \\
\hline
\end{tabular}

$\mathrm{O}$ texto de Veja não menciona o fato de Serra Leoa ter população majoritariamente muçulmana. Como indica a Tabela 2, também não traz de maneira explícita, através de discurso direto ou indireto, manifestação de qualquer personagem envolvido no contexto dos acontecimentos registrados no país. Há apenas pressuposições, afirmações e presunções. Se estudiosos da história e analistas da atual conjuntura do país africano foram ouvidos, os leitores não são informados. O contexto da guerra é, no relato de Veja, completamente despolitizado, pois, segundo ela, o único objetivo da disputa é ver quem vai roubar maior quantidade de diamantes, a única riqueza do país. O que o autor presume, certamente através de textos que leu e de pessoas que ouviu mas não revelou, é que Serra Leoa é o pior lugar do mundo. Não é um dos piores, não tem indicadores piores ou aspectos piores que outros países, simplesmente é o pior lugar do mundo, onde os envolvidos na guerra não têm motivações políticas, só a ganância. O fato de o país ter sido criado para ser uma colônia e receber escravos emancipados pelos ingleses após a independência dos Estados $\underline{\text { Unidos e só ter despertado o interesse dos europeus quando o mineral foi descoberto, }}$ em 1930, parece não ter qualquer impacto nisso. E Veja dá a entender que toda a violência é de responsabilidade única dos negros, pois, segundo a publicação, até 1963 , dois anos após sua independência, apenas os brancos exploravam a pedra. Mas desde que as minas foram nacionalizadas, não houve mais paz. Ou seja, hoje a ONU tenta impor lucidez à região, pois quando a responsabilidade passou aos negros eles começaram a se matar, através de milícias esfarrapadas, mambembes, que são caricaturas de elementos primitivos. 
Texto 3: Reportagem revista Veja edição 1668 - 27 de setembro de 2000

\section{VIAGEM DAS ARÁBIAS}

Sauditas vêm ao Brasil para discutir coisas sérias, mas, com dinheiro à farta, caem na gandaia

Brasília e Rio de Janeiro assistiram na semana passada à passagem da maior comitiva internacional de um país só na História brasileira. Liderados pelo príncipe herdeiro do trono da Arábia Saudita, o vice-primeiro ministro Abdullah Bin Abdul Aziz Al Saud, quase 300 sauditas visitaram o Brasil. O objetivo da viagem era obter o apoio brasileiro à entrada da Arábia Saudita na Organização Mundial do Comércio, mas a intenção acabou ofuscada pelo espalhafato da comitiva, em que tudo foi superlativo. Em 1989, o então presidente José Sarney enfrentou uma enxurrada de críticas ao levar a Paris 150 brasileiros para comemorar o bicentenário da Revolução Francesa. A comitiva serve, até hoje, como emblema de trem da alegria. O presidente Bill Clinton, em sua última visita ao Brasil, trouxe pouco mais de 100 pessoas. Nada disso se compara ao gigantismo e à exuberância da delegação saudita. Além do príncipe, vieram quatro de seus filhos, três ministros, catorze irmãos, 21 membros do segundo escalão, cinquenta seguranças, 75 convidados e 130 subalternos. Era tanta gente que os nomes se repetiam. Quem, diante dessa massa, gritasse "ei, Abdullah", veria 32 cabeças se levantarem. Ao grito de "ei, Mohammed", 24 responderiam. "Fora os Estados Unidos, que trazem muitos empresários para fazer negócios, o tamanho das delegações costuma ser inversamente proporcional a sua importância”, espeta um funcionário do Itamaraty. O trem da alegria muçulmano chegou ao Brasil a bordo de seis aviões. Dois Boeing 747, dois 707 e dois jatinhos. Somados os valores de cada aeronave, a frota ultrapassa a barreira do bilhão de dólares. O avião do príncipe, um 747 que custa 220 milhões de dólares, é um dos mais luxuosos e modernos do mundo. Só a suíte real ocupa quase a metade da área do aparelho. Parece saído de um conto de As Mil e Uma Noites. Tem banheira de hidromassagem, brasão folheado a ouro e até um sistema de despiste de míssil só encontrado em aviões militares. Um colosso voador. A bagagem dos sauditas era outro monumento: 1.200 volumes. Foram necessários dez caminhões para acomodá-las. Ao todo, eram quase 8 toneladas de 
carga. Na passagem da comitiva pelo Brasil, vinte pessoas trabalharam apenas na montagem e desmontagem dessa estrutura. Não era para menos: a delegação trouxe de tudo, até a própria roupa de cama, toda a roupa de banho e os tapetes persas onde se ajoelham para rezar por Alá cinco vezes ao dia. Para se deslocar em solo, a delegação alugou doze vans, treze Vectra, 25 Omega e quatro ônibus de excursão. Um comboio de quase 300 metros que, se alguém olhasse do primeiro carro, não avistaria o último. Ao príncipe foi destinado um Cadillac, ano 1993, totalmente blindado e o único exemplar no Brasil. Pesa 4 toneladas, o dobro do normal, e suporta até ataque de explosivos.

Armas e armas - O Itamaraty nunca trabalhou tanto com apenas uma comitiva. Para liberar a bagagem dos sauditas na Receita Federal, o pessoal do cerimonial já teve dificuldades. É que a quantidade de armas chamou a atenção dos fiscais. Muitas pistolas semi-automáticas e submetralhadoras. Tudo para garantir a segurança de sua alteza real - que nunca sofreu nenhum tipo de atentado. Mas o assassinato continua a pairar sobre a família real da Arábia Saudita como uma lembrança sombria de seus deveres: na qualidade de guardiões dos lugares santos do islamismo, Meca e Medina, os governantes precisam exibir um comportamento impecável. Pelo menos publicamente. A preocupação com atentados é tão grande que, no Brasil, além dos cinquenta seguranças nativos, os sauditas requisitaram ao governo brasileiro mais 32 policiais federais. Nos hotéis onde se hospedaram, todos os visitantes, antes de entrar, tinham de submeter suas bolsas e objetos a um detector de raio $X$, como esses que existem nos aeroportos.

Na cerimônia do Palácio do Planalto, na qual o príncipe Abdullah se encontrou com o presidente Fernando Henrique, houve dois problemas. O primeiro: os árabes queriam porque queriam entrar no palácio com todos os seguranças devidamente armados. Conseguiram. Na recepção oficial no Palácio do Planalto, um ministro brasileiro chegou a ficar tenso. Viu umas quarenta autoridades árabes perfiladas, ao lado de menos de dez brasileiros. "Fiquei receoso de que eles imaginassem que não estávamos valorizando o encontro", diz o ministro. Na hora do almoço oficial, deu-se o segundo incidente: o príncipe cometeu uma gafe pouco comum entre chefes de Estado. Deixou o presidente Fernando Henrique e os demais 200 convivas esperando por mais de uma hora. O motivo: estava cansado e resolveu tirar uma soneca antes de encontrar o presidente. Coisas de monarcas.

Carneiros e carneiros - A família real Al Saud, que domina a Arábia Saudita, concentra mais de $40 \%$ de toda a renda nacional. Daí tanta ostentação. Fica nos cofres 
dos membros da monarquia boa parte dos 200 bilhões de dólares que o país arrecada todos os anos vendendo petróleo. É uma concentração de riqueza que se repete nos emirados vizinhos encharcados de petróleo - e em nenhuma outra parte do mundo. Só o príncipe herdeiro Abdullah, 75 anos, tem uma fortuna pessoal de 3 bilhões de dólares. Tem quatro mulheres e mantém a forma dando braçadas em sua piscina-olímpica, é claro - no palácio em Riad. Adora corridas de camelos e detesta mentiras, dizem os súditos. A renda per capita da Arábia Saudita é pouco maior que a brasileira e mal bate nos 7.000 dólares. O Brasil é quase dez vezes mais populoso e quatro vezes maior que a Arábia Saudita em extensão territorial. Mesmo assim, os sauditas gozam de razoável qualidade de vida. Os serviços públicos funcionam bem e o povo tem expectativa de vida quase igual à europeia. A segurança pública é absoluta. Em 1998, foram cometidos 53 assassinatos em todo o país, o mesmo que num fim de semana mais agitado em São Paulo. Uma das explicações para isso é a severa legislação árabe. $O$ rei pode mandar matar e mutilar quem não cumprir a sharia, a lei sagrada do islamismo. O monumentalismo da delegação do príncipe que desembarcou no Brasil se explica pelo excesso de zelo para proteger sua alteza. Cada membro da comitiva tem uma função específica. Tudo deve ser feito de maneira que o príncipe não estranhe o local que esteja visitando. Por essa razão, a delegação trouxe uma pessoa cuja missão é apenas ajudar o príncipe a se vestir e outra para acompanhá-lo o tempo todo e evitar que ele caia. Da numerosa equipe fazem parte um barbeiro, uma massagista e copeiros particulares. Também vieram o chefe de cozinha da realiza e mais quatro ajudantes. Só eles sabiam como preparar o cardápio predileto de sua alteza: carneiro assado. Em apenas um jantar, na suíte real em que se hospedou em Brasília, foram consumidos dezoito carneiros. No dia seguinte, a refeição foi mais leve: dezesseis carneiros. Outra paixão é o chá de jasmim. Sempre com adoçante. Após cada refeição, o príncipe toma uma xícara de chá para ajudar na digestão. É praxe ele se retirar para um local mais calmo, mais reservado, e ficar à vontade para jactar-se.

Dólares e dólares - Numa comitiva tão cheia de barbas e bigodes, tão exclusivamente masculina, havia apenas duas mulheres - e americanas, uma delas encarregada de fazer massagem em sua majestade três vezes ao dia. A Arábia Saudita é uma sociedade com padrões culturais duros de engolir, ao menos para o gosto dos ocidentais, em especial no que se refere à discriminação das mulheres. Num país com taxa de alfabetização masculina de mais de $80 \%$, apenas a metade das mulheres sabe ler $e$ escrever. Cobertas com um manto negro da cabeça aos pés, dois véus que tapam 
completamente o rosto e, no caso das mais radicais, luvas de algodão, as mulheres só podem sair acompanhadas. Em qualquer lugar público existe uma entrada separada para elas. A segregação é tanta que há agências bancárias e restaurantes só para homens. Elas não podem compartilhar o mesmo ambiente com homens que não sejam da família. Não lhes é permitido viajar sozinhas nem dirigir. A "polícia religiosa", armada com varas de bambu, vigia o comportamento feminino e zela pela observação das preces diárias. Talvez por isso, quando na companhia de mulheres, os sauditas deixam entrever um comportamento distorcido: tendem a encarar como desfrutáveis, quase objetos de aluguel, todas as mulheres que não vivam, como as suas, trancadas em casa e cobertas como múmias. A passagem da comitiva pelo Brasil é a segunda perna de uma viagem que começou na Cúpula do Milênio, em Nova York, e terá a Argentina e a Venezuela como próximas paradas. Os preparativos para a visita ao país foram feitos com três meses de antecedência, mas nem tudo saiu perfeito. A maior reclamação do príncipe era em relação ao tamanho das camas nos hotéis em que se hospedou. Na Arábia Saudita, ele dorme numa cama de 25 metros quadrados. Isso mesmo: 25 metros quadrados! Em seu avião particular, ele tem uma de 10 metros quadrados. No Brasil, a maior cama em que dormiu tinha 5 metros quadrados. Em Brasília, os árabes ficaram hospedados em dois hotéis: o Naoum Plaza e o Carlton. No Naoum, a delegação ocupou 95\% dos quartos e gerou um consumo recorde. Cada um dos 163 quartos alugados pelos sauditas consumiu 800\% a mais do que a taxa normal. A opulência era tamanha que havia dois quartos apenas para bagagem. "Realmente tivemos um faturamento espetacular. Eles lavaram roupa, telefonaram, comeram e beberam mais do que os outros hóspedes”, diz Maurício do Valle, diretor do Naoum. Diante de comitiva tão numerosa e tão rica, vinda ao Brasil para falar de negócios, alguns empresários nacionais coçaram os bolsos. Em certos casos, tiveram sucesso. Numa loja de perfumes de Brasília, por exemplo, os sauditas levaram todo o estoque de fragrâncias das marcas Jean Paul Gaultier, Calvin Klein e Issey Miyake. Gastaram 13.000 reais. Ou 400 barris de petróleo pela cotação de sexta-feira. Com relação a grandes negócios, nada feito. Empresários ligados à Embraer e à Avibrás, da área de aviação, marcaram audiência com o príncipe. Nenhum conseguiu fechar contrato. A romaria não se limitou a grandes empresários. Na porta do hotel dos sauditas, havia gente tentando vender jóias, comida e até pedras. Um garimpeiro, Mauro Limão, 46 anos, levu um cristal de 50 quilos para oferecer de presente ao príncipe. Também não conseguiu fazer a "aproximação comercial”. A julgar pelas relações comerciais do 
Brasil com a Arábia Saudita, é difícil fisgar os árabes. Os sauditas compram 500 milhões de dólares em produtos brasileiros, principalmente frango. Já o Brasil chegou a consumir 4 bilhões de dólares de petróleo saudita, mas, depois da decisão de privilegiar o mercado da Venezuela e da Argentina, o comércio de petróleo caiu para 1,5 bilhão de dólares.

Mulheres e mulheres - Nos hotéis em que o príncipe se hospedou, duas regras foram exaustivamente repetidas: os apartamentos não poderiam ter bebidas alcoólicas e não se permitiria servir carne de porco aos membros da comitiva. São ordens que pretendem dar a impressão de um comportamento impecável da realeza. Na própria Arábia Saudita, tais regras também existem, mas, por trás dos muros das mansões de muitos milionários, rola o outro lado da cimitarra. As bebidas alcoólicas, proibidas pelo Corão e punidas com chibatadas, são oferecidas com dupla satisfação: pelo prazer da transgressão e do exibicionismo (uma garrafa de uísque pode bater nos 100, 200 dólares). Casos de violência sexual contra empregadas estrangeiras, em geral filipinas, são abafados. Também é entre sussurros que se fala dos aviões carregados de beldades de aluguel entregues em domicílio nos palácios dos mais abastados. Mas é fora das fronteiras que muitos sauditas - os da comitiva da semana passada, por exemplo relaxam de verdade. Entre Brasília e Rio, eles não esconderam o encantamento com a beleza das mulheres tropicais, que se aglomeravam nos saguões dos hotéis à espera de, digamos, conhecer outra cultura. Quando ganhavam a honra de uma atenção, subiam aos quartos $e$ desciam três horas depois felizes da vida com 400 verdinhas americanas nos bolsos. Mais ou menos treze barris de petróleo. No Rio, os sauditas encontraram-se com o governador Anthony Garotinho e o prefeito Luiz Paulo Conde, e logo foram ao que interessa. Passearam pela orla, fizeram compras. E resolveram esticar a viagem por mais um dia sem agendar nenhum compromisso oficial. No Rio, para espanto de Alá, houve um fraternal congraçamento entre uma comitiva só de homens e a desenvoltura de bronzeadas cariocas - que, na falta de conhecimentos mais sólidos de inglês, mantinham com os sauditas um diálogo que se limitava à troca de uma única informação: o número do apartamento. 
Tabela 3: Reportagem revista Veja edição 1668 - 27 de setembro de 2000.

\begin{tabular}{|c|c|}
\hline Discurso direto & $\begin{array}{l}\text { - Funcionário do Itamaraty } \\
\text { - Ministro brasileiro } \\
\text { - Maurício do Valle, diretor do hotel } \\
\text { Naoum }\end{array}$ \\
\hline Discurso indireto & \\
\hline Pressuposições existenciais & \\
\hline $\begin{array}{l}\text { Afirmações avaliativas/presunções } \\
\text { valorativas }\end{array}$ & $\begin{array}{l}\text { - espalhafato da comitiva, em que tudo foi } \\
\underline{\text { superlativo }} \\
\text { - A comitiva serve, até hoje, como } \\
\text { emblema de trem da alegria } \\
\text { - Nada disso se compara ao gigantismo e à } \\
\text { exuberância da delegação saudita } \\
\text { - O trem da alegria muçulmano } \\
\text { - os sauditas gozam de razoável qualidade } \\
\text { de vida } \\
\text { - O monumentalismo da delegação } \\
\text { - no caso das mais radicais } \\
\text { - trancadas em casa e cobertas como } \\
\underline{\text { múmias }} \\
\text { - São ordens que pretendem dar a } \\
\underline{\text { impressão de um comportamento }} \text { impecável da realeza } \\
\text { - As bebidas alcoólicas, proibidas pelo } \\
\text { Corão e punidas com chibatadas, são } \\
\underline{\text { oferecidas com dupla satisfação: pelo }} \\
\text { prazer da transgressão e do exibicionismo } \\
\text { - O príncipe cometeu uma gafe } \\
\text { - Daí tanta ostentação } \\
\text { - Sauditas vêm ao Brasil para discutir } \\
\text { coisas sérias, mas, com dinheito à farta, }\end{array}$ \\
\hline
\end{tabular}




\begin{tabular}{|l|l|}
\hline & $\begin{array}{l}\text { caem na gandaia } \\
\text { - os sauditas deixam entrever um } \\
\text { comportamento distorcido }\end{array}$ \\
\hline & \\
\hline & \\
\hline & \\
\hline
\end{tabular}

A análise da intertextualidade no texto "Viagem das Arábias" mostra que Veja deu explicitamente voz a alguns personagens envolvidos no contexto da história relatada, mas negou voz aos principais retratados, ou seja, os membros da comitiva em visita ao Brasil. A maioria das posições foi retratada através de pressuposições avaliativas e presunções valorativas. Sem que uma explicação para tal procedimento fosse apresentada, a revista optou por não revelar as identidades de dois dos entrevistados que aparecem em discurso direto.

A revista nos apresenta ao longo do texto os seguintes argumentos: a comitiva tinha como características o gigantismo e o monumentalismo, mas era desimportante, pois, segundo o suposto funcionário do Itamaraty, o tamanho das delegações costuma ser inversamente proporcional a sua importância. Veja evidencia um clima de desconfiança com relação a qualquer questão relacionada aos árabes/muçulmanos. Diz, por exemplo, que os governantes sauditas precisam exibir um comportamento impecável, mas ressalta que isso se dá pelo menos publicamente. A revista sugere com isso que talvez em privado o comportamento não exiba a mesma retidão. A dissimulação árabe/muçulmana também foi identificada pela revista com relação às regras (que) foram exaustivamente repetidas: nos apartamentos não poderia ter bebidas alcóolicas e não se permitiria servir carne de porco aos membros da comitiva. Mas para a revista, essas são ordens que pretendem dar a impressão de um comportamento impecável da realeza. Ou seja, para Veja, são ordens apenas fictícias, que pretendem apenas dar uma impressão sobre o comportamento dos integrantes da delegação. A revista reforça a suspeita quando descreve alguns hábitos do príncipe herdeiro Abdullah, que adora corridas de camelos e detesta mentiras, mas novamente faz questão de ressaltar que isso é o que dizem os súditos. Veja não acredita nos árabes/muçulmanos, mas acredita cegamente no que leu ou ouviu em algum lugar não identificado, tanto que não vê necessidade em atribuir à fonte, tornando suas, as acusações de que na própria Arábia Saudita, tais regras (para um comportamento 
impecável) também existem, mas, por trás dos muros das mansões de muitos milionários, rola o outro lado da cimitarra. As bebidas alcoólicas, proibidas pelo Corão e punidas com chibatadas, são oferecidas com dupla satisfação: pelo prazer da transgressão e do exibicionismo (uma garrafa de uísque pode bater nos 100, 200 dólares). A revista não se preocupa em apontar qualquer evidência, apenas diz que muitos, e muitos podem ser cinquenta ou a totalidade dos sauditas, são transgressores das leis sagradas do islamismo. E não apenas isso. São também autores, de acordo com Veja: (de) casos de violência sexual contra empregadas estrangeiras, em geral filipinas, (que) são abafados. Said (1990, p. 81) já havia apontado tal posição no âmbito do Orientalismo. Segundo ele:

\footnotetext{
Podemos generalizar sobre as figuras de linguagem associadas ao Oriente sua estranheza, sua diferença, sua sensualidade exótica [...] Todas elas são declarativas e auto-evidentes; o tempo do verbo que elas usam é o eterno intemporal [...] "Maomé é um impostor [...] Nenhum embasamento é preciso; as provas necessárias para condenar Maomé estão contidas no [...]".
}

A revista aponta indicadores que poderiam ser considerados positivos - do ponto de vista dos indicadores sociais - encontrados na Arábia Saudita: os serviços públicos funcionam bem e o povo tem expectativa de vida quase igual à européia. A segurança pública é absoluta. Em 1998, foram cometidos 53 assassinatos em todo o país, o mesmo que num fim de semana mais agitado em São Paulo. Isso, no entanto, não leva a uma avaliação positiva da revista, que considera que os sauditas gozam apenas de uma razoável qualidade de vida.

Texto 4: Reportagem revista Veja edição 1669 - 4 de outubro de 2000.

\section{DE NARIZ NOVO}

\section{Plástica nasal é a moda entre as iranianas}

Desde que os aiatolás chegaram ao poder no Irã e trataram de atrasar o relógio da História, as mulheres só podem sair à rua vestidas dos pés à cabeça. Os cabelos são cobertos por véus, e batas disformes de cores discretas escondem as curvas do corpo. Rosto e mãos são as únicas partes à mostra desde que o fundamentalismo islâmico impôs suas regras, há 22 anos. Assim, é natural que por lá a vaidade feminina se 
concentre em cuidados com o rosto. As iranianas carregam na maquiagem para boca e olhos - e, naturalmente, nada mais em moda do que fazer plástica no nariz. Em outros países, as mulheres evitam aparecer em público até que sumam as marcas da operação. Nas ruas de Teerã é comum vê-las exibindo o curativo de cirurgia recente. Alguns esparadrapos, dizem as fofocas, chegam a ser puro fingimento, usados só para aparentar maior status social.

Entre as iranianas mais abastadas já é difícil encontrar quem exiba o nariz que Alá lhe deu. A preferência é por mudanças radicais, bem perceptíveis. Nada de alterações mínimas, condizentes com a necessidade de preservar a harmonia do rosto, cuidado que predomina no Brasil, um centro de excelência quando o assunto é cirurgia plástica. As iranianas têm comumente nariz volumoso, de modo que todo narizinho arrebitado que se vê por lá é com certeza produto de bisturi. Para atender à demanda, os médicos mais requisitados costumam marcar até sete operações para o mesmo dia. "Só umas poucas mulheres querem mudanças abaixo do pescoço”, disse Ali Akbar Jalali, um dos mais conhecidos cirurgiões plásticos de Teerã, em entrevista ao jornal The New York Times. "Isso porque há poucas oportunidades no Irã de ver corpos femininos. Só o marido veria o resultado da cirurgia." O rosto é tudo que as iranianas podem mostrar, e não se poupam esforços para melhorá-lo. O lifting facial, técnica utilizada para rejuvenescer a face, é outro recurso difundido. Custa em média 3.000 dólares, três vezes o preço de uma reforma nasal completa. Tatuagem nas sobrancelhas para torná-las mais escuras, uso de lentes de contato coloridas - importadas clandestinamente dos Estados Unidos e vendidas livremente nas farmácias pelo equivalente a 15 dólares o par - e implante temporário de longas unhas também estão na moda. Teerã também vem se enchendo de academias de ginástica e salões de beleza. A procura não é tanto pelos serviços que oferecem. $O$ que encanta as mulheres é o fato de que nesses locais, nos quais homens não entram,é possível tirar o véu e mostrar à vontade os cabelos bem-cuidados sem se preocupar com a tirania da polícia religiosa. No Irã, a mulher que exibir além de um rosto com um belo nariz arrebitado pode ir para a cadeia ou levar chibatadas em público.

Tabela 4: Reportagem revista Veja edição 1669 - 4 de outubro de 2000.

$$
\text { Discurso direto }
$$




\begin{tabular}{|l|l|}
\hline & \\
\hline Discurso indireto & \\
\hline Pressuposições existenciais & $-o$ fundamentalismo islâmico \\
& $-a$ tirania da polícia religiosa \\
& - O que encanta as mulheres \\
\hline $\begin{array}{l}\text { Afirmações avaliativas/presunções } \\
\text { valorativas }\end{array}$ & - trataram de atrasar o relógio da História \\
\hline & \\
\hline & \\
\hline
\end{tabular}

Assim como nos exemplos anteriores, a análise mostra que Veja estabelece uma posição de fechamento para a diferença, privilegiando pressuposições em detrimento de discursos diretos e indiretos em seu texto. A única atribuição direta realizada pela revista é do iraniano Ali Akbar Jalali em declaração que o médico deu ao jornal norteamericano The New York Times, como informa a publicação. O que Veja não informa é que toda a reportagem baseia-se no material publicado pelo diário nova-iorquino no dia 22 de setembro de 2000 e publicado a seguir ${ }^{47}$. É interessante comparar os parágrafos inicias das reportagens. O que no New York Times foi publicado como "[...] unlike women in many places, who hide the chiseling and sawing and stretching done to their faces, Iranian women wear their post-surgical bandages like badges of honor, or at least indicators of a certain degree of wealt.", em Veja saiu como “Em outros países, as mulheres evitam aparecer em público até que sumam as marcas da operação. Nas ruas de Teerã é comum vê-las exibindo o curativo de cirurgia recente. Alguns esparadrapos, dizem as fofocas, chegam a ser puro fingimento, usados só para aparentar maior status social." . Uma vez que claramente Veja não esteve em Teerã para realização da reportagem e nem ouviu iranianos envolvidos no contexto, de onde teria a reportagem tirado a afirmação “dizem as fofocas”? Outras frases parecem traduções literais. Basta comparar o que foi publicado no New York Times - "Iranian women tend to have noses

\footnotetext{
${ }^{47}$ Disponível em: $<$ http://movies.nytimes.com/learning/students/pop/000922qodfriday.html?scp=1\&sq=Ali\%20Akbar\%20J alali\&st $=$ cse $>$.
} 
on the straight and strong side, so a button nose is likely to be man-made" - com o publicado em Veja: “As iranianas têm comumente nariz volumoso, de modo que todo narizinho arrebitado que se vê por lá é com certeza produto de bisturi.".

Mas se Veja reproduziu boa parte do conteúdo da reportagem do The New York Times, não copiou a maneira de fazer jornalismo da publicação norte-americana. Enquanto a publicação brasileira contentou-se em dar voz a uma única pessoa, o médico Ali Akbar Jalali, o diário norte-americano utilizou em seu texto dez discursos diretos. A revista brasileira preferiu pressuposições existenciais, como a tirania da polícia religiosa, dando como certo que toda a polícia iraniana é tirana, ainda que o texto de onde Veja tirou todas as informações diga que Women are rarely stopped on the street any longer by morals policemen for wearing makeup, além de optar pelas presunções valorativas como atrasar o relógio da história, fazendo valer a recorrente imagem de um Islã atrasado, que para ser compreendido precisa ser reduzido a tenda e tribo (SAID, 1990, p. 114).

Outro ponto que deve ser observado é a utilização do sintagma fundamentalismo islâmico na frase "Rosto e mãos são as únicas partes à mostra desde que o fundamentalismo islâmico impôs suas regras, há 22 anos..”. Sobre tal uso, diz Said que:

The deliberately created associations between Islam and fundamentalism ensure that the average reader comes to see Islam and fundamentalism as essentially the same thing. Given the tendency to reduce Islam to a handful of rules, stereotypes, and generalizations about the faith, its founder, and all of its people, then the reinforcement of every negative fact associated with Islam - its violence, primitiveness, atavism, threatening qualities - is perpetuated. And all this without any serious effort at defining the term "fundamentalism", giving precise meaning either to "radicalism" or "extremism", or giving those phenomena some context (for example, saying that 5 percent, or 10 percent, or 50 percent of all Muslims are fundamentalists) $\left(1997\right.$, p. xvii) ${ }^{48}$.

\footnotetext{
48 “As associações deliberadamente criadas entre Islã e fundamentalismo garantem que o leitor médio passe a ver Islã e fundamentalismo como essencialmente a mesma coisa. Dada a tendência para reduzir o Islã a um punhado de regras, estereótipos e generalizações sobre a fé, seu fundador, e todos seus seguidores, então o reforço de todos os fatos negativos associados ao Islã - a sua violência, primitivismo, atavismo, qualidades ameaçadoras - é perpetuado. E tudo isso sem qualquer esforço sério em definir o termo 'fundamentalismo', dando significado preciso tanto para 'radicalismo' ou 'extremismo', ou dando a esses fenômenos algum contexto (por exemplo, dizendo que 5 por cento, ou 10 por cento, ou 50 por cento de todos os muçulmanos são fundamentalistas)."
} 


\section{Iran's Well-Covered Women Remodel a Part That Shows -}

Reportagem The New York Times - 22 de setembro de 2000

\section{By ELAINE SCIOLINO}

TEHRAN - The law in Iran requires women to cover their hair and to conceal the shape of their bodies in loose clothing.

So a cool thing to do in Tehran these days is to get a nose job.

So cool that unlike women in many places, who hide the chiseling and sawing and stretching done to their faces, Iranian women wear their post-surgical bandages like badges of honor, or at least indicators of a certain degree of wealth.

And when only the face of a woman shows, it is not hard to detect who has been redone. Iranian women tend to have noses on the straight and strong side, so a button nose is likely to be man-made.

"It's just like women's clothing — things go in and out of fashion," said Dr. Ali Akbar Jalali, a leading plastic surgeon in Tehran who spent last summer doing laser training in Cleveland. "And what's in fashion right now is getting the nose done. After that come face-lifts.

"Only a small percentage of women want body work because there are so few opportunities in Iran to see women's bodies. No seashore, no swimming pools - except for women. So if women do body work, it's for their husbands. The face is really the only part that can be seen."

For centuries, a woman's beauty has been an essential component of Iranian culture.

"Kill me, but make me beautiful," one Iranian proverb goes. "The beautiful face soothes the tired heart and opens the closed door," goes another. The works of the medieval poets Hafiz and Saadi are filled with deep longing for beautiful women, although the clerics insist that the images of perfumed hair and luminous faces refer to spiritual, not temporal, love.

Lili Moghimi is typical of the women who believe in artificial enhancement. She has had her nose fixed to make it smaller and straighter - twice. She has had her eyebrows tattooed to darken them. And she has bought nonprescription contact lenses in four different colors - blue, dark green, light green and hazel — to accessorize her clothing and reflect her moods. 
Ms. Moghimi, a 30-year-old mother of two, is rail-thin, a result of constant dieting and aerobics and swimming classes at a swank women-only gym that doubles as a social club. Her long nails (implants that last for months) are painted pearly white. The Islamically correct coat and matching scarf she wears over a black miniskirt and snug shirt are from Italy.

"Part of the reason for spending so much attention on the way I look is that it's in our culture," she said. "It's in the nature of Iranian women to want to look beautiful. Part of the reason is that I don't have anything else to do. My only job is to cook and take care of my home. So I spend time on myself."

Obviously, many Iranian women are too busy working or studying to concern themselves as much as Ms. Moghimi does about their appearances. But neither do they fit their ubiquitous image in the West: dour creatures swathed from head to toe in black. Rhinoplasty in particular has become so widespread that the feminist magazine Zanan devoted an eight-page cover story to the subject in its August issue. The cover showed an artificial nose superimposed on the face of a woman. The headline read, "Young Women and Men and the Hot Market in Nose Jobs."

The article included interviews with women who had undergone the surgery. "Unfortunately, in my family everyone has bad noses," said a 20-year-old called Haleh after she had had her nose shrunk. "This is a very, very serious flaw. Their faces change after the operation. They suddenly look beautiful. So all our family members are very sensitive about the shape of our noses, and everywhere we go we make comments about people's noses."

The mother of a 17-year-old whose nose had been changed surgically said: "We did her nose so she could become more beautiful and enjoy her face for the rest her life. I could see that she had a flaw in her face, and I was very glad we could get rid of it." Another young woman, named Golnush, spoke of a computer image of herself that her fiancé had done for the doctor - with red hair and blue eyes and without the bump on her long nose.

The cosmetic surgery boom is aided by enthusiastic surgeons, many of whom have trained in the United States. After performing seven cosmetic surgeries one day, for example, Dr. Jalali told a visitor that she should consider shortening her forehead a centimeter and having the horizontal and vertical lines on her forehead removed. He even un-Islamically pulled back her head scarf and stretched her skin to show how he would do it. 
He told her young Iranian colleague with drop-dead good looks: "You have a delicate nose. It only needs a bit of the hump removed. And when you smile a horizontal line forms on your upper lip and a flare at the tip of your nose that is not very beautiful". His fees are \$1,000 for a nose job, \$3,000 for a radical face-lift, \$1,200 for a breast reduction or for an abdominal tuck. They are high by Iranian - but not by American or European - standards, and many of his clients are Iranian expatriates who come to Iran for the summer and go back home "refreshed."

"A few years ago all my friends seemed to be having hysterectomies," said a 50-ish Iranian woman. "You couldn't say hello to a doctor without him suggesting that you have a hysterectomy. Now it's nose jobs and face-lifts."

Even if they do not resort to plastic surgery, Iranian women often invest heavily in hairdressers, aerobics classes, makeup, clothes and lingerie. Colored contact lenses, made in America and available without a prescription at pharmacies for about $\$ 15$ a pair, are best sellers for both women and men. Bookstores stock books like "Face-Lifts Without Surgery" and "The Secrets of Being Young and Beautiful." Women are rarely stopped on the street any longer by morals policemen for wearing makeup, prompting many young women to apply clown- like colors to their faces. One of the most important private meeting places for women is the beauty salon, where they can take off their head scarves, relax and socialize. Ayatollah Ruhollah Khomeini, the father of Iran's revolution, once tried to ban all beauty parlors, calling them "dens of corruption." In the end, all he did was to put male hairdressers - and female barbers - out of business.

Salons offer haircuts, coloring and blow-drying; facials, massages and makeup treatment; manicures and pedicures; tattooing of the eyebrows, eyelids and lip lines; and a variety of techniques for bleaching, tweezing and removal of both facial and body hair. It takes about five hours to get a bride coifed, painted, depilated, manicured, creamed and perfumed. The cost is equivalent to almost two months of an average government worker's salary.

"Just because women have to cover their heads doesn't mean they don't want to get their hair done or their eyebrows shaped," said Goli, 42, the owner of one of Tehran's fanciest beauty salons, who asked that her full name not be used. "In fact, women do it to feel human."

Some women visit their beauty salons as often as once a week. "When so little hair can be revealed in public, there's nothing worse than dark roots," said one customer. Other 
women cut or color their hair in wild colors as an act of rebellion, allowing the bangs to show. "I saw my stepsister the other day and she had dyed her hair yellow!" exclaimed Ms. Moghimi. "Not blond, yellow."

And there are accounts in Iranian newspapers from time to time about teenage girls who cut their hair short and dress as boys to rebel against the restrictive dress code. As for Ms. Moghimi, she continues her quest to become more and more beautiful. "I want a smaller nose, like a doll's nose," she said. "I'm willing to pay lots of money to a plastic surgeon to give me a new look. I don't want to have any faults in my face. I'd like to look beautiful, like Marilyn Monroe." 


\section{3 - Análise corpus imediatamente pós-11 de setembro}

Texto 5: Carta ao leitor revista Veja - Edição especial 1718 - 19 de setembro de 2001.

\section{Carta ao leitor}

O verdadeiro alvo visado pelos terroristas que atacaram Nova York e Washington na semana passada não foram as torres gêmeas do sul de Manhattan nem o edifício do Pentágono. $O$ atentado foi cometido contra um sistema social e econômico que, mesmo longe da perfeição, é o mais justo e livre que a humanidade conseguiu fazer funcionar ininterruptamente até hoje. Não foi um ataque de Davi contra Golias. Nem um grito dos excluídos do Terceiro Mundo que, de modo trágico mas efetivo, se fez ouvir no império. Foi uma agressão perpetrada contra os mais caros e mais frágeis valores ocidentais: a democracia e a economia de mercado.

O que realmente incomoda a ponto de exasperação os fundamentalistas, apontados como os principais suspeitos de autoria dos atentados, não é só a arrogância americana ou seu apoio ao Estado de Israel. O que os radicais não toleram, mais que tudo, é a modernidade. É a existência de uma sociedade em que os justos podem viver sem ser incomodados e os pobres têm possibilidades reais de atingir a prosperidade com o fruto do seu trabalho. Esse é o verdadeiro anátema dos terroristas que atacaram os Estados Unidos. Eles são enviados da morte, da elite teocrática, medieval, tirânica que exerce poder absoluto em seus feudos. Para eles, a democracia é satânica. Por isso tem de ser combatida e destruída.

Tabela 5: Carta ao leitor revista Veja - Edição especial 1718 - 19 de setembro de 2001.

\begin{tabular}{|l|l|}
\hline Discurso direto & \\
\hline Discurso indireto & \\
\hline Pressuposições existenciais & $-o s$ fundamentalistas \\
& $-a$ arrogância americana \\
& $-o$ radicais \\
\hline
\end{tabular}




\begin{tabular}{|c|c|}
\hline $\begin{array}{l}\text { Afirmações avaliativas/presunções } \\
\text { valorativas }\end{array}$ & $\begin{array}{l}\text { - Não foi um ataque de Davi contra } \\
\text { Golias. Nem um grito dos excluídos do } \\
\text { Terceiro Mundo que, de modo trágico mas } \\
\text { efetivo, se fez ouvir no império } \\
\text { - O que os radicais não toleram, mais que } \\
\text { tudo, é a modernidade } \\
\text { - uma sociedade em que os justos podem } \\
\underline{\text { viver sem ser incomodados e os pobres }} \\
\underline{\text { têm possibilidades reais de atingir a }} \\
\underline{\text { prosperidade com o fruto do seu trabalho }} \\
\text { - Eles são enviados da morte, da elite } \\
\text { teocrática, medieval, tirânica que exerce } \\
\text { poder absoluto em seus feudos. Para eles, } \\
\underline{\text { a democracia é satânica }} \\
\text { - um } \underline{\text { sistema social e econômico que, }} \\
\text { mesmo longe da perfeição, é o mais justo } \\
\underline{\text { e livre que a humanidade conseguiu fazer }} \\
\text { funcionar ininterruptamente até hoje } \\
\text { - os mais caros e mais frágeis valores } \\
\text { ocidentais: a democracia e a economia de } \\
\text { mercado. }\end{array}$ \\
\hline
\end{tabular}

O texto não registra qualquer discurso direto ou indireto, o que condiz com o gênero editorial e com o subgênero carta dos editores, inseridos dentro da categoria jornalismo opinativo, proposto por José Marques de Melo (2003). Fundador da Escola de Comunicação e Artes da USP e primeiro pesquisador a receber o título de doutor em uma universidade brasileira, ele faz questão de ressaltar que ao separar metodologicamente jornalismo informativo e jornalismo opinativo não pretende "absolutamente fazer crer que a expressão opinativa (tomada no sentido de direção ideológica) se reduza à Segunda categoria" (2003. p. 73). Marques de Melo também nos diz que "editorial é o gênero jornalístico que expressa a opinião oficial da empresa 
diante dos fatos de maior repercussão no momento" (2003, p.103). E é isto, de fato, o que encontramos nesta carta ao leitor. Uma observação mais atenta nos leva a perceber que a opinião da revista está toda permeada pela questão econômica, diretamente associada à democracia, na visão de Veja. Ela afirma que o atentado foi cometido contra a economia de mercado, o sistema mais justo e livre, onde os justos podem viver sem ser incomodados e os pobres têm possibilidades reais de atingir a prosperidade. Utilizando o pensamento do pesquisador boliviano Raul Rivadeneira Prada ${ }^{49}$, Melo diz ser indispensável caracterizar as "relações de propriedade" da instituição jornalística:

[...] pois, nas sociedades capitalistas, o editorial reflete não exatamente a opinião dos seus proprietários nominais, mas o consenso das opiniões que emanam dos diferentes núcleos que participam da propriedade da organização. Além dos acionistas majoritários, há financiadores que subsidiam a operação das empresas, existem anunciantes que carreiam recursos regulares para os cofres da organização através da compra de espaço [...] (MELO, 2003, p.104).

É importante dizer que a análise que aqui se faz não pretende discutir se a economia de mercado é de fato o sistema mais justo e livre e se esse sistema permite chances reais de os menos favorecidos atingirem a prosperidade. O que se avalia aqui são os mecanismos textuais utilizados pela publicação para difundir sua própria visão de mundo pelo tecido da sociedade como um todo, uma visão que evidentemente não é única, mas aparece como tal na construção realizada por Veja. Para Thompson (2009, p. 82-83), essa é uma estratégia de construção simbólica estabelecida no contexto da ideologia, entendida como sentido ou significado, e a maneira como ela serve para estabelecer e sustentar relações de poder. No arcabouço desenhado pelo sociólogo britânico, a operação identificada na Carta ao Leitor se encontra na estratégia típica universalização, onde acordos institucionais são apresentandos como servindo aos interesses de todos, dentro do modo geral legitimação, que estabelece e sustenta relações de dominação por serem representadas como legítimas, ou seja, justas e dignas de apoio.

\footnotetext{
${ }^{49}$ RIVADENEIRA PRADA, R. Periodismo. La teoría general de los sistemas y la ciencia de la comunicación. México: Ed. Trillas, 1977.
} 
Texto 6: Reportagem revista Veja - Edição especial 1718 - 19 de setembro de 2001.

\section{ESCOLAS DE TERROR}

Depois do terrorismo étnico, do religioso, do independentista e do nacionalista, amadurece o terror que funciona como o braço armado de nações criminosas

Como idéia e prática, o terrorismo é quase tão antigo quanto a guerra. O uso sistemático da violência imprevisível e desmedida contra civis com objetivos políticos é registrado há séculos. O historiador grego Xenofonte (431-350 a.C.) descreve sua utilização na Antiguidade. Como toda tática militar, o terrorismo evoluiu e se tornou mais mortífero, como comprova o ataque da semana passada contra Washington e Nova York. Pode-se dizer que esses atentados são fruto de um novo tipo de terrorismo. A destruição das torres da metrópole símbolo da riqueza americana exigiu uma ação de guerra planejada, organizada e bem financiada. Por todas as complexidades envolvidas, dificilmente poderia ter sido executada por grupelhos clandestinos, movidos apenas por fanatismo cego ou pelo fervor revolucionário, esgueirando-se de porão em porão. Os especialistas dizem que a operação deve ter sido montada numa base física qualquer, protegida da vigilância externa. Não é trabalho improvisado de fugitivos em desespero de causa. A revista americana Foreign Affairs, respeitada publicação especializada em análises internacionais, batizou há alguns anos esse tipo de ação de terrorismo pós-moderno. “A característica fundamental dessa modalidade de terror é o fato de seus militantes não agirem por motivação própria. Eles são o braço armado de um governo que não se sente forte o bastante para declarar guerra aberta a outro", escreveu Walter Laqueur na Foreign Affairs. O articulista lembra que, diante da nova ameaça, passa para um segundo plano entre as preocupações globais o terrorismo de inspiração puramente nacionalista, como o do IRA, o exército de libertação da Irlanda do Norte, ou o ETA, cujo objetivo declarado é obter da Espanha a independência da província basca. "Nunca nos perdoaremos pelo erro de tratar esses novos terroristas como indivíduos loucos movidos somente por razões étnicas, religiosas ou ideológicas. Não. Eles devem ser enfrentados como realmente são, ou seja, soldados de forças especiais, ligados a exércitos regulares, mantidos por governos de nações aparentemente pacíficas", escreveu o ensaísta americano Caleb Carr em outra 
publicação especializada, o World Policy Journal. $O$ componente religioso tem influência marcante na ousadia dos atos terroristas mais recentes, especialmente os atentados suicidas praticados por extremistas islâmicos. Mas o sacrifício em nome de Deus dá conta de apenas parte do fenômeno. Sobre esse particular é bom lembrar o que escreveu o melhor historiador contemporâneo das guerras, o inglês John Keegan. Ele conta que em quase todos os conflitos, em exércitos de quase todas as nações, os comandantes nunca tiveram problemas em recrutar voluntários para missões de altíssimo risco. É uma verdade óbvia, mas nem sempre clara. Para ficar com um único exemplo, o ataque aéreo sobre Tóquio, com o qual os americanos tentaram dar uma resposta imediata ao ataque japonês a Pearl Harbor na II Guerra Mundial, envolveu dezesseis aviões bombardeiros. Nenhum voltou a sua base. Mesmo sabendo que a missão era sem volta - um porta-aviões americano lançou os bombardeiros perto da costa e retornou para o mar alto -, para cada piloto que efetivamente voou apareceram dez dispostos a morrer. "Entre as várias facetas do terrorismo islâmico, a existência de mártires é o fenômeno menos interessante", disse Keegan. "Longe de ser a exceção, o sujeito que entrega voluntariamente a vida por uma causa é a regra em um grande número de situações bélicas." É preciso, no entanto, traçar uma linha de distinção entre o que é missão de enorme risco e o que é suicídio certo. Na missão perigosíssima, o soldado sabe que provavelmente morrerá, mas tem uma porta aberta no imaginário para a salvação na última hora. Acredita que, completada a tarefa, talvez encontre um jeito de sobreviver, mesmo que isso seja muitíssimo improvável. No ataque sobre Tóquio, alguns dos pilotos americanos nutriam a esperança de descer em lugar ermo depois do ataque e, de alguma forma, alcançar a China. No caso específico do terror islâmico, o indivíduo parte para uma ação em que sua morte é o passo inicial que desencadeará os resultados desejados. Ele não quer evitar a morte, porque isso inviabilizaria a missão. Segundo analistas, a motivação interior dos terroristas também está ligada a tentações mundanas que costumam passar despercebidas pelos que observam o fenômeno de longe: eles também querem dinheiro, prestígio $e$ reconhecimento social. E isso se consegue em países que incentivam e dão guarida a esses grupos. "Um fuzil automático tem em certas capitais do mundo o mesmo efeito hipnótico sobre os jovens que um computador pessoal ou um carro zero-quilometro", diz Richard Betts, professor de ciência política da Universidade Columbia, em Nova York. É instigante a idéia de que os terroristas se lançam nessa atividade também porque ela é material, social e espiritualmente valorizada nas comunidades onde eles 
vivem. Do ponto de vista da Faixa de Gaza, de Cabul e de outros centros depauperados do mundo islâmico, ser recrutado para uma atividade terrorista é uma distinção notável. Outra questão pouco compreendida é o apoio que os grupos de terror recebem. "Os terroristas agem agora com tanta ousadia e eficiência porque suas organizações são protegidas por uma rede de conexões logísticas que correm pelas capitais de muitos países com os quais os Estados Unidos mantêm relações aparentemente normais", disse o professor Henry Kissinger, velha águia americana, que foi ministro de diversos governos de seu país. "Certos atos de violência coletiva acabam acontecendo por motivos bem mais simples do que imaginamos: mata-se em muitos casos porque isso, por alguma razão, se torna permitido e porque os meios repentinamente passam a estar ao alcance”, diz Jan Gross, autor de um livro recente intitulado Vizinhos. A obra de Gross é focada no massacre de judeus por seus conterrâneos poloneses ocorrido na cidade de Jedwabne, na Polônia em 1941. Ele mostra que só o ódio ao próximo não explica o desencadeamento fisico, real, do terror assassino. Judeus e poloneses viveram se odiando, mas em paz, durante décadas. Essa falsa paz durou até a chegada das tropas nazistas à cidade. A infantaria de Hitler deu ao ódio ancestral os meios e a certeza da impunidade que os cidadãos de Jedwabne precisavam para dar início ao extermínio dos vizinhos. Os terroristas pós-modernos estão obtendo nas capitais dos países que os protegem esses mesmos ingredientes: os meios para agir e a certeza da impunidade para planejar meticulosamente seus atos criminosos. O surgimento do terrorista de Estado, financiado, protegido e guiado por governos, é algo novo. Mortalmente novo. Em apenas um dia, 11 de setembro, numa única cidade, Nova York, mais cidadãos americanos morreram em mãos de inimigos do que soldados americanos na Guerra do Golfo. São ações de açougueiros que, fora de alguns círculos obtusos, não atraem simpatia para a causa defendida pelo terror. É um aparente paradoxo do terrorismo: quanto mais mortífera e bem-sucedida sua ação, mais ela reverte contra os interesses dos defensores da causa que motivou a ação criminosa. Certamente, o dia 11 de setembro será lembrado como aquele em que o terrorismo cruzou uma linha divisória, foi longe demais, e nunca mais um ato dessa natureza será encarado com a mesma complacência do passado. Foi para o terrorismo e para a causa dos terroristas igualmente um dia trágico, insensato. A historiadora americana Barbara Tuchman dedicou um livro à tentativa de explicar por que ao longo da história governos e grupos frequentemente perseguem "políticas contrárias a seus próprios interesses”. Ela deu a essa obra o título significativo de A Marcha da 
insensatez. Barbara Tuchman mostra que governantes, em geral despreparados para os desafios que a realidade lhes joga no colo, se deixam enredar por suas máquinas de guerra, compromissos políticos, influências religiosas ou ideológicas. Eles simplesmente perdem a razão. E se perdem. Assistem a seu país e seus planos de governo serem arrastados para o lixo da história por ambições desmedidas de parentes e altos funcionários. Desafiam inimigos poderosos e, frequentemente, se metem em guerras impossíveis de ser lutadas - quanto mais vencidas. Enfiam seu povo em armadilhas históricas que resultam em miséria e sofrimento.

Por que, então, mesmo trazendo dentro de si o germe da própria destruição, o terrorismo não morre? Ao contrário, se aprimora, se refina e parece cada dia mais ousado? Porque, como as drogas pesadas no cérebro dos usuários, o terrorismo proporciona uma euforia política inicial a seus autores e simpatizantes difícil de ser vencida. Esse efeito teatral esteve na base das ações terroristas que abalaram o mundo há 100 anos, quando do surgimento do anarquismo como força política na Europa. Para os anarquistas, o ato terrorista em si era uma vitória. Em 1894, os anarquistas mataram o presidente francês Sadi Carnot. Alguns anos mais tarde esfaquearam fatalmente a imperatriz Elizabeth, da Áustria, e mataram o primeiro-ministro espanhol, Antônio Cãnovas. Umberto I, rei da Itália, e William McKinley, presidente dos Estados Unidos, foram as vítimas seguintes dos anarquistas. O terrorismo, pela primeira vez, apareceu na pauta dos governantes como seu problema mais sério. De Dostoievski a Henry James, escritores registravam a ação dos assassinos políticos. No decorrer do século XX, o terrorismo foi combatido de todas as formas e sempre conseguiu ressurgir metamorfoseado. Os comunistas inventaram o terrorismo de Estado, a criação de formidáveis máquinas de financiamento e treinamento de assassinos politicamente motivados. No auge da Guerra Fria, Cuba exportava terroristas e tecnologias de assassinato de oponentes para a América Latina. Os americanos, por intermédio da CIA, faziam o mesmo. A arena política foi transformada em um palco de ousadias miúdas, já que os arsenais nucleares de lado a lado impediam um confronto direto das duas potências.

Por ter sido tratado como um subproduto da Guerra Fria, reação inevitável de grupos submetidos a invasores cruéis, o terrorismo nunca foi enfrentado com toda a força que sua virulência exige. A comunidade internacional sempre empurrou a questão com a barriga. Mesmo diante de evidências assustadoras da ousadia sem fim do terror, o adiamento sempre venceu. Gastaram-se centenas de reuniões da ONU simplesmente para definir o que era 
terrorismo. Foram momentos memoráveis da demagogia inerente aos fóruns de discussão da comunidade internacional. Em 1972, nas Olimpíadas de Munique, quando onze atletas israelenses foram mortos num atentado terrorista, o então secretário-geral das Nações Unidas, o austríaco Kurt Waldheim, tentou levar a ONU a uma ação mais decidida contra o terror. Fracassou. Foi derrotado por argumentos dos árabes segundo os quais os movimentos tachados de terroristas apenas lutavam a favor de direitos fundamentais, como liberdade e independência, e contra o racismo e o colonialismo. Venceu a tese de que mais importante que o combate à violência terrorista seria a erradicação de suas causas - que seriam a injustiça, a exploração, a desigualdade. Em um célebre discurso da ONU em 1974, o líder palestino Yasser Arafat defendeu a tese de que um povo que luta pela própria independência tem o direito de apelar para atos terroristas. Foi muito aplaudido. Impecável na teoria, o discurso de Arafat e o apoio que ele recebeu abriram a porta a abusos de toda ordem. Em dez anos o número de grupos terroristas de expressão mundial multiplicou-se por cinco. Chegaram a ser 55 em 1978. Quantos deles lutavam contra invasores ou pela independência do país? Uma meia dúzia, especialmente na África. Os demais apenas aproveitaram a onda favorável. A Organização para a Libertação da Palestina (OLP), de Arafat, hoje oficialmente convertida em um organismo que abomina o terrorismo, foi no passado uma incubadora de entidades terroristas. A OLP foi a primeira a treinar outras organizações terroristas e a organizar cursos periódicos de terrorismo e guerrilha urbana em seus campos de refugiados no Líbano e na Jordânia. Por seis semanas de curso, cada participante pagava até 10000 dólares. No auge de sua atividade, a OLP chegou a arrecadar com suas aulas cerca de 600 milhões de dólares anuais. $O$ terrorismo deve, em parte, sua trajetória de sucessos no decorrer do século XX ao fato de muitos países que então sofreram sua ação terem lançado mão dele no passado. $O$ caso de Israel é emblemático. Os judeus tiveram de lutar pela independência, mesmo depois que a ONU criou ali o Estado de Israel. O terrorismo era moeda comum. $O$ inimigo? Os ingleses. Os pais fundadores de Israel, como o ex-primeiro-ministro Menachem Begin, ganhador do Prêmio Nobel da Paz, envolveram-se em bem-sucedidas atividades terroristas. A explosão do quartel-general das tropas inglesas no hotel King David, em Jerusalém, em 1946, foi o ato mais ousado do terror dos israelenses. A cena do hotel com as janelas despedaçadas chocou a opinião pública inglesa. Mais algumas semanas e as tropas de sua majestade abandonaram a Palestina. Os próprios americanos reconhecem hoje que muitas de suas ações na Guerra do Vietnã nos anos 
60 e 70 só podem ser descritas como atos de terrorismo. A mais abominável delas talvez tenha sido a chamada Operação Phoenix, hoje abertamente admitida pelos americanos como um erro histórico. A operação levou ao assassinato de altos dirigentes sul-vietnamitas favoráveis à convivência pacífica com o Norte comunista. Justamente para poderem valer-se de expedientes condenáveis, os Estados Unidos nunca declararam guerra oficialmente ao Vietnã do Norte. Hoje, a natureza do terrorismo mudou. "O terrorismo é um teatro", disse a VEJA Brian Jenkins, estudioso do fenômeno da violência política da Universidade Saint Andrews, da Escócia. Na semana passada, ele escolheu seu palco mais disputado, Nova York a cidade mais cosmopolita do mundo e a menos americana dos Estados Unidos. Terrorismo sem palco não existe, já que, por mais devastador, o impacto de suas bombas e tiros não tem o poder de derrubar governos e regimes. Espera-se que, ao ter atingido seu mais ambicioso alvo na semana passada, essa forma odiosa de assassinato coletivo tenha também encontrado seu caminho para a extinção.

Tabela 6: Reportagem revista Veja - Edição especial 1718 - 19 de setembro de 2001.

\begin{tabular}{|l|l|}
\hline Discurso direto & $\begin{array}{l}\text { - Walter Laqueur, historiador norte- } \\
\text { americano } \\
\text { - Caleb Carr, novelista e historiador norte- } \\
\text { americano } \\
\text { - John Keegan, historiador britânico } \\
\text { - Richard Betts, professor norte-americano } \\
\text { de ciência política da Universidade } \\
\text { Columbia } \\
\text { - Henry Kissinger, ex-ministro norte- } \\
\text { americano } \\
\text { - Jan Gross, historiador e sociólogo norte- } \\
\text { americano } \\
\text { - Barbara Tuchman, historiadora norte- } \\
\text { americana } \\
\text { Discurso indireto }\end{array}$ \\
\hline especialista em terrorismo \\
\\
\hline
\end{tabular}




\begin{tabular}{|c|c|}
\hline & $\begin{array}{l}\text { - Foreign Affairs } \\
\text { - Walter Laqueur, historiador americano } \\
\text { - John Keegan, historiador britânico } \\
\text { - Barbara Tuchman, historiadora } \\
\text { americana }\end{array}$ \\
\hline Pressuposições existenciais & $\begin{array}{l}\text { - Depois do terrorismo étnico, do } \\
\text { religioso, do independentista e do } \\
\text { nacionalista } \\
\text { - No caso específico do terror islâmico } \\
\text { - Do terrorista de Estado }\end{array}$ \\
\hline $\begin{array}{l}\text { Afirmações avaliativas/presunções } \\
\text { valorativas }\end{array}$ & $\begin{array}{l}\text { - o terror que funciona como o braço } \\
\text { armado de nações criminosas } \\
\text { - Os comunistas inventaram o terrorismo } \\
\underline{\text { de Estado }} \\
\text { - o terrorismo nunca foi enfrentado com } \\
\text { toda a força que sua virulência exige } \\
\text { - Foram momentos memoráveis da } \\
\frac{\text { demagogia inerente aos fóruns de }}{\text { discussão da comunidade internacional }} \\
\text { - Impecável na teoria, o discurso de Arafat } \\
\text { e o apoio que ele recebeu abriram a porta } \\
\text { a abusos de toda ordem } \\
\text { - Os judeus tiveram de lutar pela } \\
\text { independência } \\
\text { - Os pais fundadores de Israel [...] } \\
\text { envolveram-se em bem-sucedidas } \\
\text { atividades terroristas } \\
\text { - A revista americana Foreign Affairs, } \\
\text { análises internacionais } \\
\text { - Henry Kissinger, velha águia americana }\end{array}$ \\
\hline
\end{tabular}




\begin{tabular}{|l|l|}
\hline & - bem-sucedidas atividades terroristas \\
\hline & \\
\hline & \\
\hline
\end{tabular}

Parece-nos interessante aqui, antes de sinalizar as operações gramaticais e de vocabulário realizadas por Veja, observar a coesão e estrutura textual, os dois últimos itens listados por Fairclough (2001, p. 101-114) para a análise textual, sendo a coesão relacionada à ligação entre orações e frases e a estrutura textual às propriedades organizacionais de larga escala dos textos.

A reportagem começa apresentando a ideia de que os atentados de 11 de setembro

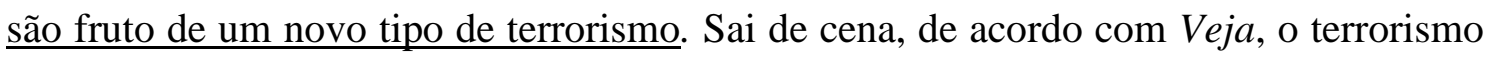
levado a cabo por ideais ou pelo fervor revolucionário e entra em quadro um terrorismo que funciona como braço armado de um governo que não se sente forte o bastante para declarar guerra aberta a outro. É, segundo a revista, um tipo de terrorismo diferente do praticado por grupos como o ETA e o IRA, de inspiração puramente nacionalista. A diferença estabelecida pela revista pode, em uma análise rápida, parecer inofensiva. Mas é peça fundamental na tese que se estrutura no texto. Utilizando declaração do historiador norte-americano Caleb Carr, o argumento é por uma ofensiva militar, um ataque contra um país todo, pois, na ótica da publicação, os terroristas devem ser enfrentados como realmente são, soldados de forças especiais, ligados a exércitos regulares, mantidos por governos de nações aparentemente pacíficas. Para o que poderia surgir como uma contradição, ou seja, a faceta islâmica da violência frente ao esvaziamento completo de um componente ideológico, Veja encontra suporte no historiador britânico John Keegan, para quem o componente religioso tem influência marcante na ousadia dos atos terroristas, mas o sacrifício em nome de Deus dá conta de apenas parte do fenômeno. Ou seja, primeiro os atos não são ideológicos; depois, são, mas só um pouco. Mas como explicar o martírio, se os terroristas são soldados regulares agindo não por ideais mas por profissionalismo? Veja faz parecer fácil, até banal, fenômeno menos interessante, na opinião do mesmo Keegan. É, no entanto, obrigada a recorrer a esforço para tentar dar coerência à tese de que em exércitos de quase todos os países é possível encontrar combatentes dispostos a morrer em batalha. O exemplo utilizado é o ataque norte-americano contra Tóquio em resposta a Pearl Harbor, quando 
$\underline{\text { mesmo sabendo que a missão era sem volta, para cada piloto que efetivamente voou }}$ apareceram dez dispostos a morrer. O problema é que a chamada Operação Doolittle, como ficou conhecida, não era sem volta. Dos dezesseis bombardeiros, de fato, nenhum voltou a sua base. Mas dos oitenta tripulantes que ocuparam as aeronaves, setenta e três voltaram com vida da missão, ou seja, menos de dez por cento da tropa tombou em combate. Este, no entanto, é um dado que a revista esconde, preferindo se empenhar em uma ginástica semântica para tentar mostrar que o ato suicida não caracteriza necessariamente um componente ideológico. Segundo Veja, em muitas missões o soldado sabe que provavelmente morrerá, mas acredita que no fim da missão talvez encontre um jeito de sobreviver, mesmo que isso seja muitíssimo improvável. Ou seja, primeiro a revista diz que os soldados que se apresentaram para bombardear a capital japonesa sabiam que a missão era sem volta, mas depois diz que alguns dos soldados tinham a esperança de conseguir pousar e posteriormente chegar até a China. Nada disso vale para o terror islâmico, que não quer evitar a morte, especialmente por razões ideológicas, pois, para Veja, o que motiva os terroristas são as tentações mundanas, ou seja, dinheiro, prestígio e reconhecimento social. E tal fato, na opinião da revista, é instigante, por ser a atividade terrorista espiritualmente valorizada nas comunidades $\underline{\text { onde eles vivem. Do ponto de vista da Faixa de Gaza, de Cabul e de outros centros }}$ depauperados do mundo islâmico, ser recrutado para uma atividade terrorista é uma distinção notável. Ou seja, não é um ato ideológico e extremo de alguns em alguns países que têm maioria islâmica. Da maneira como Veja coloca, é uma realidade incontestável e que abrange toda a comunidade de um número incontável de centros do mundo islâmico, seja lá o que isso queira dizer. Tal raciocínio ajuda a reforçar o argumento de que a resposta ao 11 de setembro precisa vir em forma de ataque contra países do Oriente Médio, pois o apoio ao ato bárbado foi conseguido, na tese que a publicação brasileira reproduz, em países que incentivam e dão guarida aos autores. É $\underline{\text { nas capitais desses países que os protegem que eles encontrariam os meios para agir e a }}$ certeza da impunidade. Os argumentos de Veja são tão confusos que as contradições aparecem dentro do intervalo de um parágrafo. No primeiro, a publicação afirma que pode-se dizer que $\underline{\text { esses atentados são fruto de um novo tipo de terrorismo, um tipo de ação do terrorismo }}$ pós-moderno, onde os militantes são o braço armado de um governo. A tese ganha reforço pouco adiante, quando Veja reafirma que o surgimento do terrorista de Estado, financiado, protegido e guiado por governos, é algo novo. No parágrafo seguinte, no 
entanto, tal atividade aparece como algo existente há pelo menos cinquenta anos: $\underline{\text { Os }}$ comunistas inventaram o terrorismo de Estado, a criação de formidáveis máquinas de financiamento e treinamento de assassinos politicamente motivados. No auge da Guerra Fria, Cuba exportava terroristas e tecnologias de assassinato de oponentes para a América Latina. Os americanos, por intermédio da CIA, faziam o mesmo.

A estratégia de relatar fatos que reforcem seus argumentos enquanto esconde dados que podem colocar em questão o raciocínio desenvolvido é algo que permeia todo a reportagem. A revista relata que foram realizadas centenas de reuniões da ONU simplesmente para definir o que era terrorismo, sem no entanto explicar o real impacto que tal definição proporcionaria para as decisões da Organização das Nações Unidas. Também rememora 1972, nas Olimpíadas de Munique, quando onze atletas israelenses foram mortos num atentado terrorista, mas deixa de lado a resposta dada pelo governo israelense na ação que ficou conhecida como A Ira de Deus e resultou no assassinato de trinta e seis pessoas, fato fartamente relatado pela imprensa, inclusive por publicação da mesma editora de $V_{e j a}{ }^{50}$. A diferença entre o tratamento dado a muçulmanos e judeus permite observar operações discursivas que expressam o posicionamento da revista na reprodução do discurso hegemônico norte-americano também no que diz respeito à ligação Estados Unidos-Israel. A revista relata que no debate realizado na ONU venceu a tese de que mais importante que o combate à violência terrorista seria a erradicação de suas causas - que seriam a injustiça, a exploração, a desigualdade. Cita discurso de Yasser Arafat, impecável somente na teoria, pois tal discurso e o apoio recebido abriram a porta a abusos de toda ordem. Ainda segundo a revista, os países árabes são aproveitadores, pois poucos, uma meia dúzia, especialmente na África, de fato estavam lutando pela independência ou contra invasores, os demais apenas aproveitaram a onda favorável. Mas enquanto as questões ligadas a países de maioria muçulmana estão todas colocadas na teoria e ganham verbos no futuro do pretério, Veja garante que os judeus, eles sim, tiveram de lutar pela independência, pois nesse caso o terrorismo era moeda

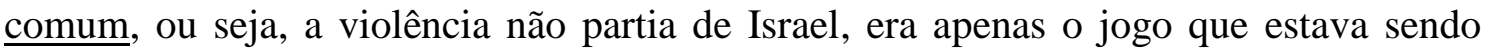
jogado. Nesse caso, também surgem adjetivos e os substantivos são suavizados, os israelenses estão envolvidos em bem-sucedidas atividades terroristas, que resultam em ato ousado. A revista se refere à explosão do quartel-general das tropas inglesas no hotel King David, em Jerusalém, em 1946. Mas assim como Veja não revelou os dados que

\footnotetext{
${ }^{50}$ Disponível em: <http://historia.abril.com.br/fatos/atentado-munique-ira-deus-434571.shtml>.
} 
dariam outro entendimento da Operação Doolittle, aqui também não revela que tal ato ousado matou 92 pessoas e é ainda celebrado em Israel ${ }^{51}$. Nas páginas da revista, tal ação ganhou, junto com outros oito atentados terroristas, destaque em pequenos boxes acompanhados de fotografias ao longo da reportagem. Curiosamente, dos oito boxes a destacar tais ações, o que registra o atentado contro o hotel King David é o único a não relatar o número de mortos como resultado do ataque. A revista também registra duas vezes que o então primeiro-ministro israelense, Menachem Begin, que ordenou os ataques, ganhou o Prêmio Nobel da Paz, mas não faz o mesmo quando se trata do palestino Yasser Arafat, igualmente vencedor do prêmio, em 1994. Tal situação encontra explicação nas constantes estruturais relatadas por Norbert Elias e John L. Scotson. Eles perceberem que

[...] o grupo estabelecido tende a atribuir ao conjunto do grupo outsider as características "ruins" de sua porção "pior" - de sua minoria anômica. Em contraste, a auto-imagem do grupo estabelecido tende a se modelar em seu setor exemplar, mais "nômico" ou normativo - na minoria de seus "melhores" membros. (2000, p. 22-23).

Segundo os autores, há sempre algum fato para provar que o grupo favorecido é "bom", enquanto o outro é "ruim".

É importante também observar que, de maneira direta ou indireta, Veja deu voz a oito pessoas na reportagem. Mas destas, sete são norte-americanas e uma inglesa, ou seja, vozes que vêm dos dois principais países da coalizão que, menos de vinte dias depois da publicação da reportagem, invadiriam o Afeganistão em resposta aos ataques de 11 de setembro. E três destas vozes têm ascendência judaica - Walter Laqueur, Jan Gross e Barbara Tuchman - em um texto que claramente antagoniza as ações de muçulmanos e judeus. Said não se enganaria se incluísse Veja entre a New Yorker, New York Review of Books e Atlantic Monthly quando ele diz que essas publicações "never carry essays (or even literary works) in translation by Muslim and Arab authors but rely instead on experts such as Viorst ${ }^{52}$ to interpret political and cultural actualities shaped not by the facts but by unexamined presuppositions". ${ }^{53}$ (SAID, 1997, p. xxvi).

\footnotetext{
${ }^{51}$ Disponível em: <http://www.timesonline.co.uk/tol/news/world/middle_east/article690085.ece>.

${ }^{52}$ Milton Viorst, jornalista norte-americano. Segundo Said, apesar de afiado, falha ao desfiar um arsenal de pressupostos não examinados sobre o Islã.

53 “nunca trazem ensaios (ou ainda trabalhos literários) traduzidos de autores muçulmanos ou árabes, mas confiam em especialistas como Viorst para interpretar questões baseado não em fatos, mas em pressuposições não examinadas"
} 
Texto 7: Reportagem revista Veja edição 1719 - 26 de setembro de 2001.

\section{"Ou estão do nosso lado ou do lado dos terroristas"}

Com um fervor patriótico e união nacional nunca vistos desde a II Guerra Mundial, os Estados Unidos vão ao contra-ataque ao terror. Para a civilização ocidental, a opção é vencer ou vencer

Sem raiva do inimigo, que eles mal conheciam, com a opinião pública mundial $e$ doméstica francamente contra, os militares americanos assim mesmo fizeram do Vietnã um campo experimental da brutalidade armamentista. Na Guerra, que acabou em derrota para eles, em 1973, os americanos utilizaram contra o inimigo vietnamita todo o arsenal moderno de destruição - armas químicas, bombas incendiárias e de fragmentação, bombardeios diuturnos a cidades e aniquilamento de aldeias inteiras. Só não usaram armas nucleares. O conflito declarado na quinta-feira passada por um discurso histórico do presidente George W. Bush ao Congresso Americano pode ser $\begin{array}{lllll}\text { ainda mais devastador } & \text { para }\end{array}$ Antes que examinem as hipóteses bélicas da guerra contra o terrorismo anunciado por Bush, é preciso lembrar que os Estados Unidos entraram, desta vez, num conflito em que têm uma única opção: vencer ou vencer. A vitória dos americanos na guerra que começou na semana passada está assegurada até mesmo pelo absurdo insustentável da hipótese contrária: um Ocidente dominado por mulás islâmicos enlouquecidos pelo poder absoluto exercido por meio do braço armado de seus terroristas suicidas. Essa é a primeira guerra do império americano que começa com a simpatia de todas as nações livres do mundo. É a primeira também à qual eles se lançam impulsionados por uma opinião pública irada com o assassinato premeditado de 6.000 civis, imolados num palco de exposição planetária, Nova York, a cidade mais cosmopolita da Terra. $O$ que a máquina dos Estados Unidos é capaz de fazer nessas circunstâncias? Ouçamos seu comandante-em-chefe, Bush, no discurso de quinta-feira: "Nossa reação envolve muito mais que ataques isolados. Americanos não devem esperar uma batalha, mas, sim, uma campanha longa, diferente de qualquer outra que nós já vimos. Ela pode incluir ataques dramáticos mostrados pelas televisões e operações tão secretas que até mesmo seu sucesso permanecerá sigiloso. Vamos cortar os financiamentos dos 
terroristas, jogar uns contra os outros, fazê-los correr de um lugar para o outro até que não haja mais refúgio nem descanso. Vamos perseguir nações que ofereçam ajuda ou abrigo seguro ao terrorismo. Cada país tem uma decisão a tomar. Ou está do nosso lado ou do lado dos terroristas". Os americanos lançaram-se numa guerra de aniquilação ao terrorismo com uma força moral que eles só tiveram a seu lado na II Guerra Mundial. Todos os conflitos isolados que travaram contra o comunismo durante a Guerra Fria, o da Coréia e o do Vietnã, foram lutas inglórias, inconclusas, inexplicáveis para um mundo sedento de paz. Foram guerras travadas contra uma causa um tanto abstrata e longe de ser unânime, o avanço do comunismo. O regime comunista, mesmo diante de inúmeras evidências de fracasso do modelo, nunca foi traduzido imediatamente no Ocidente como a encarnação do mal. Agora não. Agora se luta contra o terror, algo tão desumano e atroz que o apoio universal está assegurado. A unanimidade dentro dos Estados Unidos é quase total. As pesquisas mostram que 95\% dos americanos querem a guerra, mesmo que ela resulte em baixas. Vão para a batalha com o mesmo ímpeto com que marchariam para a II Grande Guerra caso os terrores do holocausto promovido pelos nazistas fossem conhecidos antes do armistício. Os terroristas islâmicos e seus patrocinadores falam em Guerra Santa. Os americanos estavam tomados por uma ira santa, ao final do discurso de George W. Bush: "O desenvolvimento desse conflito é desconhecido, mas seu final é certo. Venceremos". Mas quando e como será o ataque? Bush esforçou-se na retórica para assegurar à opinião pública que o uso da força contra os agressores de Nova York e Washington é iminente. "A hora de agir está chegando", disse ele, referindo-se aos militares. "Vocês nos deixarão orgulhosos". Bush não admitiu, mas a verdade é que os Estados Unidos foram atingidos em seus valores mais amados: as liberdades individuais e o bem-estar de uma rotina de prosperidade sem precedentes. $O$ terror atingiu em cheio o modo de vida americano. A economia andou de pernas bambas, e os cidadãos passarão em breve a conviver com leis que limitarão sua liberdade de ir e vir. Na semana passada, eles viram Dan Rather, o âncora de televisão mais frio e durão da atualidade, ir às lágrimas ao comentar o ataque terrorista no programa de entrevistas de outro símbolo do país, David Letterman. Ele próprio disse que só voltou ao trabalho para atender a um apelo de Rudolph Giuliani, prefeito de Nova York, que tenta restabelecer a normalidade em sua cidade. Viram a lendária revista The New Yorker circular de capa preta, sem suas tradicionais charges, que nunca antes haviam deixado de sair mesmo em meio a catástrofes nacionais, como o assassinato do presidente John Kennedy, em 
1963. Rufam os tambores da guerra até por quem fez carreira com a virtude da frieza e do distanciamento. "Nós vamos fincar o polegar no olho dos assassinos", disse Paul O’Neill, secretário de Tesouro, conhecido pela enorme gentileza no trato pessoal. "Dessa vez é diferente, é sujo, estamos lidando com terroristas, e não respondendo a nenhum conflito mundial”, declarou Peter McBride, filho de Sean McBride, prêmio Nobel da Paz em 1974. "Temos uma espada bem afiada que será usada em breve”, disse Dan Rather, depois de enxugar as lágrimas. Num clima desses, o inimigo não é visto como um bando de guerreiros montados em cavalos e camelos, empunhando fuzis antiquados, que efetivamente é. $O$ inimigo passa a ser perigoso como as armas que usou no atentado - aviões a jato e o fogo das explosões - e por sua retórica de destruição, como a dos versos escritos pouco tempo atrás pelo principal alvo dos americanos, o terrorista Osama bin Laden: "Os pedaços dos corpos de infiéis voando como partículas de pó / Se seus olhos vissem isso, seu coração se encheria de alegria".

Tabela 7: Reportagem revista Veja edição 1719 - 26 de setembro de 2001.

\begin{tabular}{|c|c|}
\hline Discurso direto & $\begin{array}{l}\text { - George W. Bush, presidente norte- } \\
\text { americano } \\
\text { - Paul O’Neill, secretário de Tesouro } \\
\text { norte-americano } \\
\text { - Peter MacBride, filho de Sean } \\
\text { MacBride, prêmio Nobel da Paz em } 1974 \\
\text { - Dan Rather, âncora de televisão norte- } \\
\text { americano } \\
\text { - Osama bin Laden, terrorista }\end{array}$ \\
\hline Discurso indireto & \\
\hline Pressuposições existenciais & $\begin{array}{l}\text { - do império americano } \\
\text { - } o \text { apoio universal está assegurado } \\
\text { - começa com } a \text { simpatia de todas as } \\
\text { nações livres do mundo }\end{array}$ \\
\hline $\begin{array}{l}\text { Afirmações avaliativas/presunções } \\
\text { valorativa }\end{array}$ & $\begin{array}{l}\text { - O conflito declarado } \\
\text { - A vitória dos americanos na guerra que }\end{array}$ \\
\hline
\end{tabular}




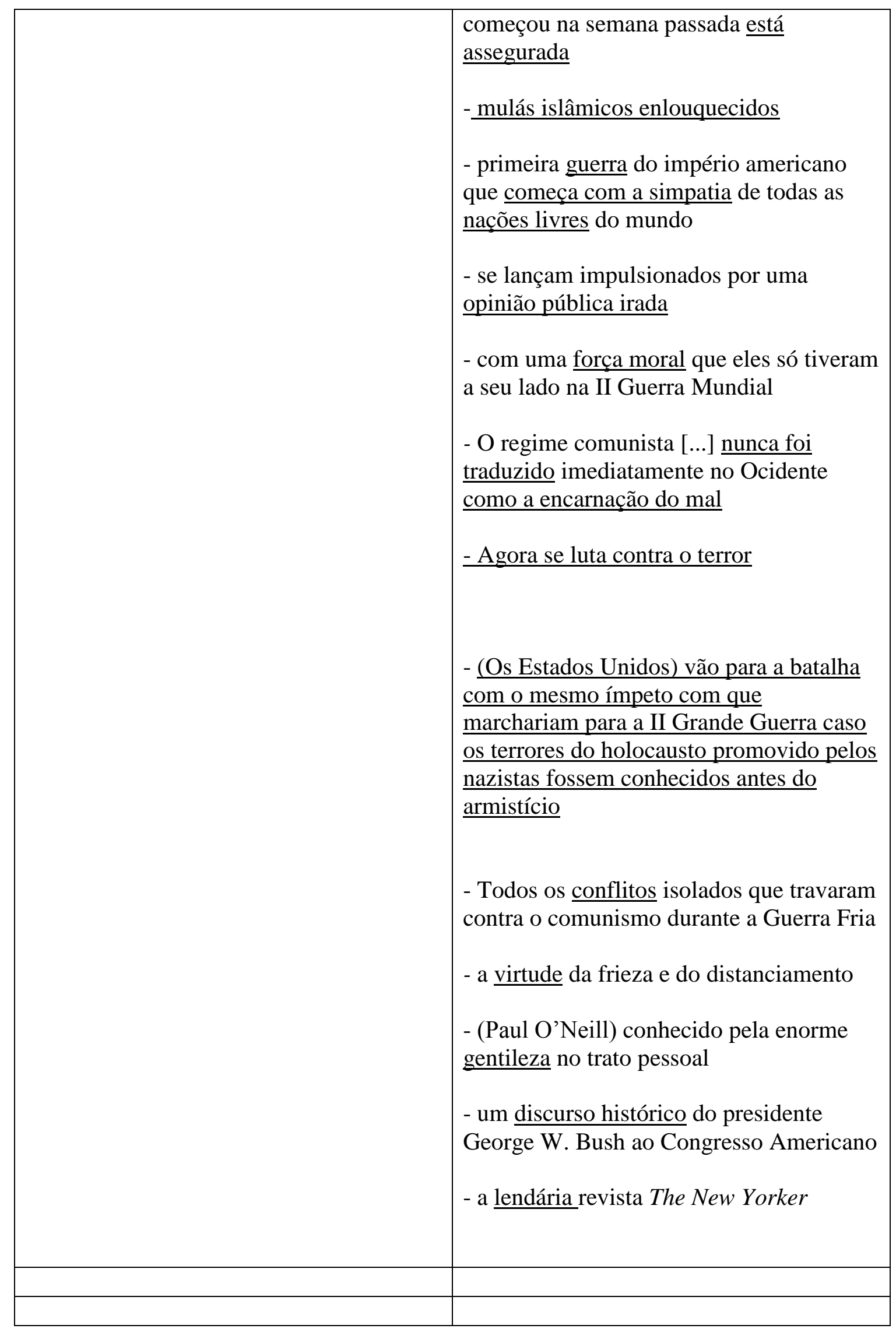


Se no texto anterior Veja construiu um discurso em defesa de um ataque contra países de maioria muçulmana, este trabalha para legitimar as brutalidades naturalmente cometidas em ações militares. A primeira operação é a separação entre "nós" e "eles", destacada em discurso direto do presidente norte-americano na manchete e reafirmada pela revista, para quem a batalha é um dever da civilização ocidental. O posicionamento traz embutida toda uma rede de significações, entre elas o segundo sentido do Orientalismo, o imaginativo - segundo Said (1990, p. 14), "um estilo de pensamento baseado em uma distinção ontológica e epistemológica feita entre 'o Oriente' e (a maior parte do tempo) 'o Ocidente"”. O problema com tais rótulos, nos alerta Said, é que: "They mislead and confuse the mind, which is trying to make sense of a disorderly reality that won't be pigeonholed or strapped down as easily as all that" ${ }^{54}$. Mas o discurso do presidente norte-americano assumido por Veja não deixou dúvidas: ou estão do nosso lado ou dos terroristas. O chamado para uma tomada de posição, uma escolha entre "nós" e "eles", reafirma essa divisão simplificadora entre Ocidente e Oriente. E é preciso estabelecer que a diferenciação é o processo central através do qual identidade e diferença são produzidas, como já exposto neste trabalho utilizando o pensamento de Tomaz Tadeu da Silva (2008). Esse processo está sempre ligado a uma forte separação entre "nós" e "eles", que supõem e ao mesmo tempo afirmam e reafirmam relações de poder.

Segundo Kathryn Woodward (2008, p. 27), "ao afirmar uma determinada identidade, podemos buscar legitimá-la por referência a um suposto e autêntico passado - possivelmente um passado glorioso [...] que poderia validar a identidade que reivindicamos". Para Veja, a identidade do "inimigo" está muito bem consolidada, “eles" são mulás islâmicos enlouquecidos, um bando de guerreiros montados em cavalos e camelos; “nós" são os Estados Unidos, que exibem uma longa tradição de batalhas e para quem o tipo de ataque que está prestes a acontecer é algo natural em sua história, um fato inevitável, pois têm uma única opção: vencer ou vencer e, por isso, vão para a batalha com o mesmo ímpeto com que marchariam para a II Grande Guerra caso os terrores do holocausto promovido pelos nazistas fossem conhecidos antes do armistício. Mas para legitimar a violência dos ataques que se avizinham Veja não apenas manipula o passado, mas também o presente, quandos diz que os Estados Unidos

\footnotetext{
${ }^{54}$ Utilizada publicação encontrada no endereço eletrônico <http://www.thenation.com/print/article/clashignorance $>$ : "Eles iludem e confudem a mente, que está tentando criar sentido em uma realidade desordenada que não será classificada ou contida tão facilmente."
} 
se lançarão ao combate com força moral e com a simpatia de todas as nações livres do mundo. A revista esconde, com isso, o resultado de pesquisa realizada pelo Datafolha e publicada pela Folha de S.Paulo no dia 23 de setembro de 2001, que aponta que "os brasileiros se opõem de forma inequívoca a que os Estados Unidos ataquem países que abrigam os responsáveis pelos ataques terroristas [...] 79\% dos entrevistados são contra essa forma de retaliação militar" 55 .

Segundo Said (1997, p. xvi), em vez de estudiosos, é comum que nós encontremos jornalistas fazendo declarações extravagantes, que são logo escolhidas e dramatizadas pela mídia, sobre o Islã. Isso é exatamente o que percebemos quando analisamos a quem Veja deu voz em uma reportagem que trata de um ataque que resultaria em milhares de mortos. A revista não ouviu qualquer especialista. Os escolhidos foram o presidente dos Estados Unidos e seu discurso histórico; o jornalista televisivo mais frio e durão da atualidade, Dan Rather; Peter McBride, cuja credencial é ser filho de Sean McBride, prêmio Nobel da Paz em 1974; e Paul O’Neill, secretário de Tesouro, conhecido pela enorme gentileza no trato pessoal, mas para quem os Estados Unidos devem fincar o polegar no olho dos assassinos. A frase de O'Neill, que em 2002 chegou a sugerir que dinheiro do FMI emprestado a Brasil e Argentina poderia parar em

contas na Suíça ${ }^{56}$ não surpreende, uma vez que o jornal britânico Finacial Times já o descreveu como alguém "que é para a sutileza verbal o que Ronaldo é para as defesas no futebol". 57

Texto 8: Reportagem revista Veja edição 1719 - 26 de setembro de 2001.

\section{Este país já está arrasado}

O miserável Afeganistão diante da ameaça de ataque dos EUA: uma história feita de resistência e tragédias, e muito pouco a ser destruído

O Afeganistão tem dois aliados que nunca falharam: a miséria e a montanha. $O$ atraso endêmico e a destruição provocada por 22 anos de guerras sucessivas são de tal ordem

\footnotetext{
${ }_{55}^{55}$ Disponível em: <http://www1.folha.uol.com.br/fsp/especial/fj2309200104.htm>.

${ }^{56}$ Disponível em: <http://www1.folha.uol.com.br/fsp/dinheiro/fi2907200210.htm>.

${ }^{57}$ Disponível em: <http://www1.folha.uol.com.br/fsp/dinheiro/fi0408200205.htm>.
} 
que há poucos alvos dignos do nome ao alcance da operação de mobilização militar desfechada para vingar os atentados terroristas contra os Estados Unidos. Não é fácil escolher o que bombardear num país sem estradas, sem hidrelétricas, sem pontes nem instalações de telecomunicações. Pior: o Afeganistão, além de tudo isso, já teve sua economia primitiva devastada por guerra anterior. Hoje, o país afegão é um lugar de cidades fantasmas. A população está em fuga para o campo, para as montanhas, para as cavernas abertas na rocha bruta, onde, nos casos mais extremos, as pessoas conseguem sobreviver comendo os sais minerais colhidos de terra fervida. Como tornar ainda pior a vida de um povo que come terra? Como intimidar uma população mantida num estado tal de ignorância que, embora soubesse da possibilidade de um bombardeio americano, a maioria não tinha idéia do motivo real? Os terríveis ataques contra Nova York e Washington nunca foram divulgados pelo Talibã, o grupo fundamentalista que permite apenas transmissões de uma única rádio, a sua, e proíbe a televisão. Tão logo tomou o poder, o Talibã pendurou televisões estraçalhadas nos postes, para mostrar ao povo o que pensava desse satânico agente da decadência ocidental. A montanha é o outro aliado desse país de geografia caprichosa, bordado por penhascos e desfiladeiros onde guerreiros de ferocidade legendária infligiram derrotas tremendas a dois impérios - o britânico, em meados do século XIX, e o soviético, no fim do século XX. O Afeganistão é tão isolado no coração da Ásia Central, tão protegido pelas fortalezas naturais fornecidas pela Cordilheira do Hindu Kush, que resistiu a todas as tentativas de conquistas permanentes nos últimos 500 anos. $O$ trauma sofrido pelos ingleses na histórica batalha de 1842 - 16000 mortos, entre britânicos, tropas coloniais e civis - foi imortalizado nos versos agora tão relembrados de Rudyard Kipling. "Quando estiveres ferido e abandonado nas planícies do Afeganistão/ E as mulheres chegarem para picar o que restou/ Toma do teu rifle e estoura os miolos", escreveu, de maneira bastante crua, o cronista do colonialismo britânico. Reunido na semana passada em Cabul com seus colegas de turbante para, ostensivamente, decidir o destino de Osama bin Laden, o chefe religioso Mawlawi Abdul Zahir invocou esse passado. "Estamos prontos para nos defender se os americanos atacarem", disse. "Nós já derrotamos seus avós ingleses e seus irmãos russos." O incauto senhor certamente ignora a potência da máquina militar americana - e a posição que a resposta ao terror passou a ocupar no cerne do interesse nacional dos Estados Unidos. A represália dos EUA terá uma força e uma capacidade tecnológica nem sequer sonhadas pelos afegãos. É difícil imaginar que o Afeganistão do Talibã subsista à operação. Nunca se verá, 
talvez, a face do líder supremo do Talibã, o mulá Mohamed Omar Akhund, que exemplifica em sua própria e misteriosa persona o radicalismo do movimento. Aos 42 anos, caolho, com a barba e o turbante obrigatórios, o mulá nunca foi fotografado como o Corão proíbe a reprodução da figura humana, os fundamentalistas estendem essa interdição, feita há mais de 1300 anos, a fotos e imagens transmitidas por TV ou cinema. O mulá não aparece em público nem fala aos fiéis, como fazem habitualmente os outros líderes religiosos. Antes do confronto com os Estados Unidos, não saía de Kandahar, a cidade arruinada onde o Talibã fincou raízes a partir de 1994 (e desde então edificou somente três obras: a mesquita, uma casa para o próprio mulá Omar e a prisão, esta a maior delas). Perto da casa nova de Omar ficava um dos muitos refúgios de Osama bin Laden no Afeganistão. O chefe terrorista saudita, um milionário com experiência internacional, sempre soube como agradar o mulá ignorante. Em pronunciamentos públicos, jura-lhe obediência e respeito. Trata esse filho de camponeses como "comandante dos crentes", título supremo dos grandes dirigentes que unem a autoridade política à religiosa, reservado no passado aos sultões do Império Otomano e, hoje, a monarcas considerados descendentes do profeta. O mimo mais precioso foi-lhe oferecido um dia antes dos atentados nos Estados Unidos. Dois agentes suicidas despachados por Bin Laden, disfarçados de jornalistas de TV, estraçalharam com uma câmara-bomba o maior inimigo do Talibã, Ahmed Shah Massoud, o carismático comandante de uma força que resiste ao domínio dos mulás num pequeno território no norte do Afeganistão. Pela ótica tribal do mulá e sua turma, é bem possível que o assassinato de Massoud seja considerado muito mais importante que a hecatombe em Nova York. Pelos padrões modernos, o Afeganistão nem sequer pode ser considerado uma nação. Sua história, nos últimos séculos, tem sido forjada no confronto entre as tentativas de unificação sob um poder central e a resistência das tribos, apegadas a atividades autônomas que vão desde a cobrança de tributos às caravanas no passado ao tráfico de heroína no presente. O rei Amanollah, que comandou a independência afegã do fugaz controle britânico, em 1919, foi uma das vítimas dessa tensão. Ele tentou fazer um governo comparativamente modernizador, com novidades quase desconhecidas, como a criação de escolas para meninas. Foi deposto no bojo da rebelião iniciada por uma tribo do norte, furiosa por perder o direito de tributo, agravada pelo repúdio popular desencadeado quando a mulher do rei teve o azar de ser fotografada com o rosto a descoberto numa viagem ao exterior. Aos olhos do mundo ocidental, o Afeganistão começou a existir efetivamente no século 
XIX, quando caiu na teia de interesses das potências da época. O império britânico, que já tinha a Índia, queria mais: impedir um avanço da Rússia czarista até o Oceano Índico, garantindo-se assim a hegemonia sobre toda a Ásia Central. O coração estratégico da região era, e continua sendo, o legendário Desfiladeiro de Kiber, a passagem através das montanhas geladas da Cordilheira do Hindu Kush, que no trecho mais estreito chega a ter apenas 3 metros de largura. Foi lá o palco do "maior desastre militar da história" da Grã-Bretanha no subcontinente indiano, ocorrido em 1842. Derrotado pela furiosa resistência à presença britânica em Cabul, o general William Elphinstone negociou a retirada de sua gente, ao todo 16.000 almas (4.000 militares, entre britânicos e indianos recrutados para o exército colonial, e 12.000 civis). Com a exceção de um único soldado, foram todos rigorosamente massacrados. Na segunda investida inglesa, entre 1878 e 1880, ataques suicidas de afegãos envoltos nas bandeiras verdes do Islã mais uma vez expulsaram as forças coloniais, que bateram em retirada deixando para trás 1.320 mortos, 1.000 rifles e 600 espadas. Não é o nacionalismo que move os afegãos, tradicionalmente fracionados entre etnias rivais - a maior delas é formada pelos patanes, de onde se originaram os talibãs. $O$ espírito de resistência nasce da tradição guerreira, característica dos povos das montanhas, e do enorme poder da religião. Um exemplo da força do Islã é a peculiar trajetória do Partido Popular Democrático do Afeganistão, a organização comunista que tomou o poder em 1978, com o "pacote marxista" completo: luta de classes, reforma social, emancipação da mulher, e assim por diante. Em um ano, já apelava a Alá, tentando cooptar os mulás. Até a charia, a forma mais primitiva de aplicação dos preceitos muçulmanos, foi incorporada. Os comunistas afegãos, teratológica criação de Moscou, engalfinharam-se entre si, propiciando um período de extraordinária instabilidade. Em um ano e oito meses, o país teve três presidentes golpistas, todos derrubados e assassinados. Foi aí que sobreveio a intervenção direta da União Soviética, com os resultados catastróficos cujos desdobramentos chegam aos dias de hoje. Os estrategistas soviéticos, sabe-se agora, desaconselharam vivamente a ocupação militar. A liderança política, sob o comando do gerontocrata Leonid Brejnev, não deu ouvidos. O Afeganistão tornou-se, notoriamente, o Vietnã do império vermelho. Agora, a possibilidade iminente de uma ação militar americana no Afeganistão está revirando o baú de memórias dos russos. Alexander Lebed, ex-general do Exército vermelho, lembrou na semana passada os reveses sofridos ante o Mujahidin, o movimento de resistência, e o ânimo retaliatório dos afegãos. A tática soviética de 
destruir aldeias inteiras falhou miseravelmente. "Para cada aldeia aniquilada, morria somente um combatente mujahidin", disse Lebed. "Os sobreviventes nos odiavam e viviam com uma única idéia: a vingança. Eles são uns lobos." Apesar da conhecida ferocidade dos combatentes afegãos, a vitória da resistência só foi possível por causa da Operação Ciclone, a gigantesca máquina de ajuda aos mujahidin montada pelos Estados Unidos. A Arábia Saudita cobria cada dólar colocado pela CIA em mãos da resistência. No Paquistão, o serviço secreto fazia as compras e entregava em mãos aos combatentes. Além do dinheiro, a CIA forneceu a arma que mudou o rumo da guerra: os Stinger, mísseis portáteis guiados por laser. Com essa máquina mortífera apoiada no ombro, os mujahidin praticamente anularam o único armamento efetivo dos russos, os helicópteros de combate que iam caçá-los nos buracos nas montanhas. Foi nessa época que começou a se formar também a chamada conexão árabe, a vasta rede de voluntários que foram combater os russos no Afeganistão e lá se formaram no extremismo mais absoluto - o ninho da serpente onde vicejaram Osama bin Laden e companhia. Combater os infiéis russos ao lado dos irmãos afegãos virou moda no mundo árabe. A empresa aérea da Arábia Saudita dava 75\% de desconto na passagem. "Todo mundo queria ir, mesmo que não fosse para lutar", relatou anos depois um desses voluntários, o sírio Karim Omar, em depoimento registrado pelo jornalista inglês Mark Huband no livro Warriors of the Prophet (Guerreiros do Profeta). "Tinha gente que andava com prostitutas em Bangcoc e depois ia lá, para se sentir purificada pela guerra santa."

Quando os soviéticos bateram em retirada, em 1989, a direção da CIA, comandada por George Bush pai, comemorou com champanhe a extraordinária vitória. Também começou, lentamente, a desativar os quadros estrangeiros, os militantes dos países árabes, ciente de que não era conveniente continuar criando corvos. A maioria deles voltou para seu país de origem, onde passaram a se dedicar a combater os regimes que os haviam enviado ao Afeganistão. Em comum, tinham o propósito de instaurar teocracias islâmicas e o ódio total e absoluto aos Estados Unidos. Da Argélia às Filipinas, do Sudão a Nova Jersey, os afganis, como esses árabes ficaram conhecidos, plantaram a bandeira ensangüentada de sua causa. Alguns acabaram voltando ao Afeganistão quando o Talibã, um grupo praticamente desconhecido, saiu dos acampamentos para refugiados no Paquistão para tomar o poder em Kandahar, primeiro, e depois no resto do país, destroçado pelas disputas entre os mujahidin. 
Osama bin Laden financiou e amparou ideologicamente os talibãs. De seus vastos recursos saiu o dinheiro que bancou a compra de 2.000 jipes Toyota Hilux, os veículos utilizados pelo Talibã para dominar rapidamente a província de Kandahar. Até hoje os jipes são usados pela polícia religiosa, que controla o tamanho da barba dos homens, o uso daquela roupa que cobre todo o rosto, a burqa, pelas mulheres, e também a hora obrigatória da reza para todo mundo. Agora, o destino de Osama bin Laden está de novo amarrado ao do Talibã - enquanto os afegãos esperam, outra vez, a guerra. Esta, se vier, poderá ser a maior de todas.

Tabela 8: Reportagem revista Veja edição 1719 - 26 de setembro de 2001.

\begin{tabular}{|c|c|}
\hline Discurso direto & $\begin{array}{l}\text { - Rudyard Kipling, escritor inglês } \\
\text { - Mawlawi Abdul Zahir, chefe religioso } \\
\text { afegão } \\
\text { - Alexander Lebed, ex-general do Exército } \\
\text { soviético } \\
\text { - Karim Omar, voluntário sírio }\end{array}$ \\
\hline Discurso indireto & \\
\hline Pressuposições existenciais & - $o$ radicalismo do movimento \\
\hline $\begin{array}{l}\text { Afirmações avaliativas/presunções } \\
\text { valorativas }\end{array}$ & $\begin{array}{l}\text { - Este país já está arrasado } \\
\text { - O atraso endêmico } \\
\text { - um país miserável } \\
\text { - } \underline{\text { economia primitiva }} \\
\text { - } \underline{\text { um povo que come terra }} \\
\text { - Como intimidar uma população mantida } \\
\text { num estado tal de ignorância } \\
\text { - Não é o nacionalismo que move os } \\
\underline{\text { afegãos }} \\
\text { - a charia, a forma mais primitiva de }\end{array}$ \\
\hline
\end{tabular}




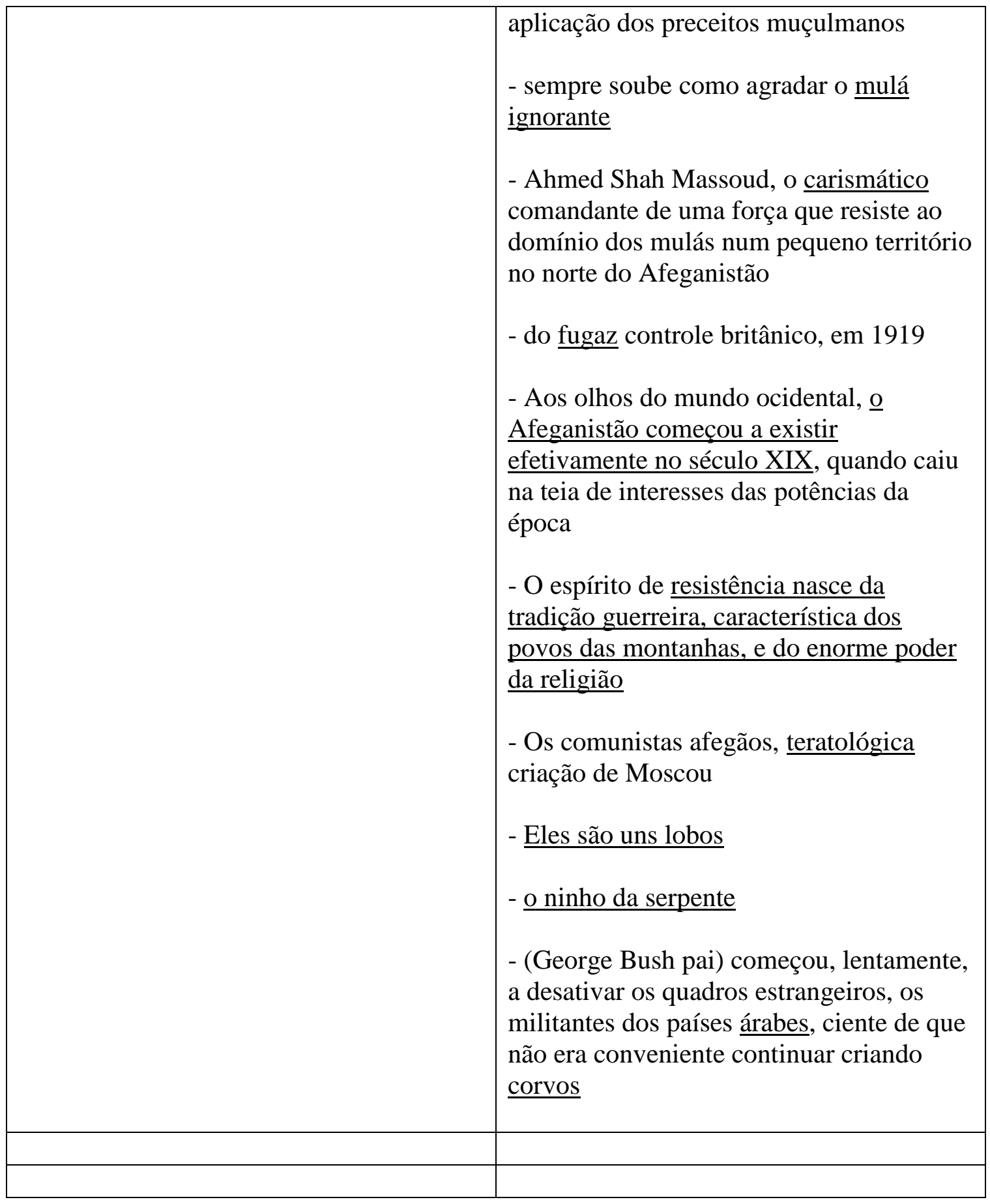

Não é preciso avançar muito no texto para compreender qual é o mote da reportagem. Não é preciso ir além do título Este país já está arrasado para ter contato com o perfil que o Afeganistão ganhará ao longo de 1902 palavras. É preciso, no entanto, ir além da imagem construída por Veja e analisar o motivo para tal representação. Segundo Veja, o Afeganistão é um país miserável onde há muito pouco a

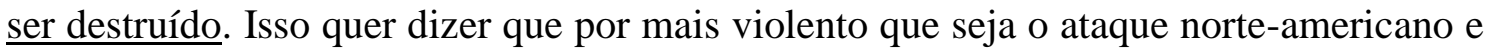


das forças aliadas ele não comprometerá profundamente o país, pois ele já está arrasado, e não foram os americanos ou ingleses que o arrasaram. Veja tenta construir a ideia de que um ataque poderoso não destruirá a economia afegã, pois ela é primitiva e já foi devastada por guerra anterior, ou seja, não seremos "nós" a destruí-la. Ainda de acordo com a publicação, o país afegão é um lugar de cidades fantasmas, ou seja, se cidades inteiras forem destruídas o cenário não irá se alterar significantemente, pois as cidades já são fantasmas. Na linha da ultrageneralização, Veja não vê problema em classificar a sociedade afegã como um povo que come terra, ainda que no mesmo parágrafo tenha ressaltado que apenas nos casos mais extremos há quem precise se alimentar dos sais minerais colhidos de terra fervida. Como tornar ainda pior a vida de um povo que come terra?, questiona Veja. Tal operação pode parecer um simples relato, mas esconde a operação de legitimação dos ataques contra o Afeganistão, amparada no estigma. Segundo Gofmann (2008, p. 15), “acreditamos que alguém com um estigma não seja humano. Com base nisso, fazemos vários tipos de discriminações, através das quais efetivamente, e muitas vezes sem pensar, reduzimos sua chance de vida". Com ou sem pensar nas consequências de tais elaborações, elas guardam semelhança com a estratégia política de extermínio de governos totalitários, no caso o Nazismo, na Alemanha, e o Bolchevismo, na União Soviética. Em seu livro Essays in Understanding: 1930-1954 (1994, p. 303), editado por Jerome Kohn, Hannah Arendt, ela própria enviada a um campo de concentração (FRY, 2009, p. 14), ao analisar os significados do terror totalitarista diz que uma das características do tratamento dado aos horrores dos campos de concentração era "to treat those who have disappeared into them as if they were already dead [...] every effort is made to create the impression not only that the person in question has died but also that has never existed at all ${ }^{58}$ ". Veja também afirma que o Afeganistão é uma terra onde o atraso é endêmico. Ou seja, a revista considera que o atraso não tem qualquer explicação histórica, é peculiar ao povo e à região, numa análise chamada pelo professor da Universidade de Stanford Lee Ross de Fundamental Attribution Error 59 , em que os atores "underestimate the sufficiency of the particular complex of situational factors [...] and must overestimate the role

\footnotetext{
58 “tratar aqueles que desapareceram dentro deles como se eles estivessem já mortos [...] Cada esforço é feito para criar a impressão não apenas de que a pessoa em questão morreu, mas também que ela nunca existiu."

${ }^{59}$ Erro Fundamental de Atribuição
} 
played by personal disposition in producing such behavior" ${ }^{60}$ (1977, p. 186). Apesar de reforçar insistentemente a imagem de ignorância, Veja não deixa que os afegãos pareçam inofensivos. Relembra que com a força da geografia, o país, de guerreiros de ferocidade legendária, derrotou britânicos e soviéticos em suas tentativas de invasão. Para dar vivacidade ao trauma sofrido pelos britânicos, destaca trecho de poema de Rudyard Kipling ${ }^{61}$. O Homem Branco do autor britânico, "visto que aparece em muitos poemas, em romances como Kim, e em demasiadas frases de efeito para ser uma ficção irônica", foi tema de análise de Said (1990, p. 232). Segundo o autor de Orientalismo, como ideia parece ter servido a muitos britânicos enquanto estavam no exterior. " Liberdade para nós e liberdade para os nossos filhos/E, frustrada a liberdade, a Guerra.' Por trás da máscara de amistosa liderança do Homem Branco, está sempre a disposição expressa de usar a força, a matar e ser morto."

Se os fatos são desprezados para contextualização, o mesmo não acontece com a religião. Segundo Veja, a resistência afegã nasce da tradição guerreira, característica dos povos das montanhas [...] e do enorme poder da religião.

Também chama a atenção a utilização de metáforas relacionadas ao mundo animal para descrever os afegãos. Veja escolheu uma frase do ex-general do Exército Soviético, Alexander Lebed, em que eles são descritos como lobos - de conhecida ferocidade, completou a revista. A rede de voluntários que foram combater os russos no país é o ninho da serpente onde vicejou Osama bin Laden. George Bush utilizou os mujahedin para derrotar os russos. A vitória foi comemorada com champagne. Mas uma vez atingido o objetivo, os militantes árabes foram descartados, pois, segundo a revista, não era conveniente continuar criando corvos. E os helicópteros russos iam, como animais entocados, caçá-los nos buracos nas montanhas. Segundo Thompson (2009, p. 86), como já visto neste trabalho, o uso da metáfora "é uma maneira eficaz de mobilizar o sentido no mundo sócio-histórico, e [...] pode estar envolto com poder, podendo servir para criar, sustentar e reproduzir relações de dominação". Pesquisa de Paul H. Thibodeau e Lera Boroditsky, da Stanford University, intitulada Metaphors we think with: the role of metaphor in reasoning $(2011, \text { p. } 1)^{62}$, mostra que:

\footnotetext{
60 “subestimam a suficiência de complexidade particular em fatores situacionais e devem superestimar o papel desempenhado por disposições pessoais ao produzir tal comportamento"

${ }^{61}$ Joseph Rudyard Kipling nasceu em Bombaim, em 30 de dezembro de 1865, e morreu em Londres, em 18 de janeiro de 1936. Autor de, entre outros, O livro da Selva, que tinha como personagem principal Mowgli, o menino lobo.

62 "Metáforas com as quais pensamos: o papel da metáfora no raciocínio", publicada em <http://www.plosone.org/article/info\%3Adoi\%2F10.1371\%2Fjournal.pone.0016782>.
} 
Even the sublest instantiation of a metaphor (via a single word) can have a powerful influence over how people attempt to solve social problems like crime and how they gather information to make "well-informed" decisions [...] Far from being mere rethorical flourishes, metaphors have profund influences on how we conceptualize and act with respect to important social issues. $^{63}$.

Os pesquisadores avaliaram se o uso de diferentes metáforas sobre crimes levaria a diferentes formas de raciocínio sobre a questão, além de diferentes propostas de combate. Para isso, focaram em duas metáforas contrastantes: crime como vírus e crime como uma besta selvagem. Os resultados mostraram que:

\begin{abstract}
When crime was framed metaphorically as a virus, participants proposed investigating the root causes and treating the problem by enacting social reform to inoculate the community, with emphasis on eradicating poverty and improving education. When crime was framed metaphorically as a best, participants proposed catching and jailing criminals and enacting harsher enforcement laws. ${ }^{64}$ (THIBODEAU; BORODITSKY, 2011, p. 2).
\end{abstract}

Texto 9: Reportagem revista Veja edição 1720 - 3 de outubro de 2001.

\title{
O VÍRUS ANTI-EUA
}

Em tempos de paz, o antiamericanismo no Ocidente é uma postura inofensiva, adotada por gente que veste jeans, toma Coca-Cola, come hambúrguer e manda os filhos para os parques da Disney World. Nas conversas dessas pessoas, os americanos são descritos como senhores do mundo mas superficiais, imersos numa cultura consumista e tosca quando comparada aos supostos refinamentos do estilo europeu. Nos dias que se seguiram ao assassinato de milhares de trabalhadores, predominantemente americanos, mas também de dezenas de outras nacionalidades, no ataque terrorista às torres gêmeas em Nova York, o uso político dessa ideologia perdeu a inocência de que habitualmente se reveste. Mal se contaram os mortos nos atentados e já viajava pelo

\footnotetext{
63 "Mesmo uma sutil instanciação de uma metáfora (através de uma única palavra) pode ter uma poderosa influência sobre como as pessoas tentam resolver problemas sociais como crime e como elas reúnem informações para tomar decisões 'bem informadas'." Longe de serem meros floreios retóricos, metáforas têm profundas influências em como nós conceitualizamos e agimos no que diz respeito a importantes questões sociais.

64 "Quando crime foi emoldurado metaforicamente como um virus, os participantes propuseram investigar as causas e tratar o problema através de reforma social para inocular a comunidade, com ênfase na erradicação da pobreza e melhoria na educação. Quando crime foi emoldurado metaforicamente como uma besta, os participantes propuseram capturar e enjaular os criminosos através da aplicação de leis mais severas."
} 
mundo a idéia de que os Estados Unidos foram, em última análise, os causadores da tragédia que se sobreu eles. Por mais graves que tenham sido os erros e até os crimes cometidos pelos americanos em sua expansão imperial no decorrer do século que se encerrou, as críticas de que foram alvo em demonstrações pelas capitais do mundo na semana passada eram elas próprias um atentado ao bom senso. Em Berlim, 15.000 jovens saíram às ruas para protestar contra os americanos, que já movimentaram suas forças bélicas para atacar os ninhos do terror no Afeganistão. Em Nápoles também houve protestos. Em Atenas, a mesma coisa. No México e na Espanha, esquerdistas picharam muros com o nome e o rosto do terrorista Osama bin Laden, celebrando-o como herói. No Brasil, os protestos foram mal disfarçados em atos pela paz convocados por partidos de esquerda e ONGs no Rio de Janeiro e em São Paulo. Manifestações antiamericanas como essas, num momento de genuína consternação planetária contra o ato terrorista, são intrigantes.

Entre os povos árabes e outras etnias que seguem o islamismo, as causas da aversão aos americanos são mais compreensíveis. A democracia e a modernidade a que se expôem os islâmicos no contato com os Estados Unidos são venenos para as elites locais. Em dois terços dos países islâmicos, os religiosos têm poder de Estado. Os mulás controlam a vida social, política, militar e econômica dos países. Definem comportamentos, estabelecem quem são os inimigos e amigos do país. Nos mais radicais, como o Afeganistão, de onde a televisão e a internet foram banidas, até o tamanho da barba é definido pelo Estado teocrático. "Para os líderes religiosos desses países, a simples existência de uma nação como os Estados Unidos já é assustadora. Mas o pavor mesmo vem do fato de os Estados Unidos não serem uma nação qualquer, mas uma potência hegemônica com interesses econômicos e presença física e militar em regiões islâmicas", diz o professor de filosofia americano Mark Hadley. Num ambiente assim, satanizar os EUA é uma opção política quase natural. Joven pauperizados e sem esperança de progresso material ouvem dos tiranos que os governam que a causa de sua miséria é externa. Dessa maneira, os governantes árabes colocam nos Estados Unidos a culpa pela própria falta de iniciativa para promover o bem-estar do povo. Mas como explicar o sentimento de aversão ao modo de vida americano em capitais do Ocidente, onde realizaram as passeatas da última semana? "O oportunismo das manifestações foi evidente. Mas será que as raízes do ódio aos Estados Unidos penetraram mais fundo do que se imaginava até então?", perguntava a revista inglesa The Economist. Realmente, o luto durou pouco demais. Ele se manteve 
apenas até o momento em que a formidável máquina de guerra americana começou a exercitar suas garras em frente das câmaras de televisão. Bastou que circulassem as primeiras imagens dos caças F-16 e dos porta-aviões americanos pelas redes de televisão para que o fervor antiterrorista fosse remodelado para uma mobilização contra a guerra de vingança dos americanos. "O número de pessoas que ainda estão chocadas com o atentado é avassaladoramente maior que o daquelas que o viram apenas como mais uma oportunidade de apedrejar os Estados Unidos", escreveu Anatol Lieven, um estudioso americano da Rand Corporation, instituição semi-oficial que há décadas assessora sucessivos governos americanos na área estratégica e foi instrumental durante os anos da Guerra Fria. Mas não se deve invalidar o argumento de Lieven apenas por sua clara filiação ideológica. A reação antiamericana foi quase instantânea e disseminada por muitas capitais do mundo. Nos países islâmicos, parecia um teatro orquestrado e perfeitamente natural. Fora dessa esfera onde Alá é a bússula dos povos, tinha a aparência de uma erupção deslocada, uma interrupção aos gritos de um processo de luto. A livre discussão das idéias é sempre um oxigênio na vida das nações porque libera pressões modernizantes que de outra forma ficariam represadas. Mas, no caso das manifestações da semana passada, o que se viu em muitos lugares foi a união velhaca de raposas da esquerda e da direita, fazendo seu proselitismo. Sob a mesma pregação contra os valores americanos, estiveram na última semana forças ideologicamente tão distantes quanto as representadas por Jean-Marie Le Pen, um racista declarado, líder da extrema direita francesa, e, por exemplo, parte da intelectualidade engajada do Brasil. Le Pen esqueceu sua plataforma política de ódio aos imigrantes de origem árabe para se entregar à tentação de colocar a culpa dos atentados nas próprias vítimas. "Os atentados são condenáveis, mas a política externa americana danosa está na origem da tragédia”, disse Le Pen.

Com ligeiras variações foi o que se ouviu de alguns porta-estandartes da esquerda brasileira e também de representantes indistintos da tolice nacional. Ato terrorista é culpa de terrorista em qualquer país que seja cometido. Em artigo no jornal Folha de S.Paulo, na segunda-feira passada, o historiador Boris Fausto, um dos mais respeitados em seu campo de atividade, escreveu o seguinte: "Depois de apresentar as condolências de praxe, essa gente (círculos nacionalistas e de esquerda) acaba dizendo, até com certo prazer, que os Estados Unidos colhem o que plantaram”. Reconhecendo os "erros e barbaridades" da sociedade americana, Boris Fausto ressalta o papel vital dos EUA na preservação da democracia e termina por convocar 
seu leitor a uma escolha: "Ou será que deveríamos lavar as mãos diante da face sinistra dos mensageiros da morte?".

Primitivo como ideologia de mobilização de massas, o antiamericanismo é um fenômeno que merece reflexão. Ele tem razões psicológicas, economômicas, religiosas, étnicas, geográficas e, certamente, ideológicas. Quase todos os países do mundo com algum peso político expressivo atraem simpatizantes e detratores. A má vontade com os Estados Unidos tem o tamanho de seu poder de maior potência militar e econômica do planeta. Resultou em parte das tensões geradas pela expansão americana, um atrito que se iniciou na primeira década do século passado e adquiriu velocidade estonteante às vésperas da entrada no terceiro milênio. A globalização econômica também carrega a impressão digital de asiáticos e europeus, mas é percebida quase universalmente como benéfica preferencialmente para os americanos. "O ritmo que a crescente eficiência e produtividade dos Estados Unidos imprimiram à economia mundial nas duas últimas décadas foi muito forte”, diz o economista ameriano Paul Krugman. "Em muitos países, ele provocou um processo de destruição criativa, que, se foi benéfico por um lado, por outro dilacerou tradições culturais e gerou insatisfações profundas."

A força avassaladora do modelo americano criou sentimentos planetários de insegurança e impotência. No plano econômico, registrou-se uma obsolescência dos parques industriais de alguns países na confrontação com modelos mais eficientes de produção de riqueza. Mercados antes protegidos foram inundados por produtos mais baratos e melhores que aqueles fabricados localmente. O movimento de globalização gerou prosperidade e eficiência econômica sem precedentes para muitas nações, e não apenas para os Estados Unidos. Mas, ao enfraquecer setores industriais tradicionais de economias retardatárias, gerou também muita insatisfação. No campo político, muitos países sentiram minada a própria soberania, à medida que o foco de muitas decisões importantes se transferia para Washington e Wall Street. Até nações poderosas acusaram o golpe dessa guinada de poder em direção aos Estados Unidos. "Quanto mais fortes eles ficam, mais estrondosa será a queda. Todo império termina em espetáculo", escreveu no The Times de Londres Matthew Parris, político do partido conservador inglês.

De um lado é típico dos impérios, em todos os tempos, atrair desafiantes ousados e doses cavalares de antipatia. Foi assim com os romanos na Antiguidade e com a própria Inglaterra. Por outro lado, é curioso que potências que exerceram ou exercem seu poder de modo muito mais discricionário que os Estados Unidos não tenham 
atraído tanta antipatia ds classes bem pensantes do mundo civilizado. A União Soviética despencou sobre si mesma numa implosão monumental de ineficiência e soberba sem que seus crimes hediondos tenham gerado metade da expasperação que a presença americana no mundo desperta. Hoje em dia, a própria China, um regime ditatorial expansionista, só parece incomodar o universo das "classes conservadoras" por ocasião do massacre de estudantes na Praça da Paz Celestial, em Pequim, no ano de 1989.

Não existem impérios inocentes. Nenhum país chega à posição de líder guindado pela ingenuidade. Os Estados Unidos com frequência são ainda arrogantes e até hipócritas. As posições recentes dos americanos renegando acordos internacionais de proteção ecológica, como o de Kioto, aliadas ao fato de serem eles os maiores produtores de gases poluentes do planeta, certamente não atraem simpatia. A recusa em bancar suas obrigações financeiras como membros da Organização das Nações Unidas, a ONU, soa para muita gente um desprezo para com a comunidade internacional. A nação mais rica do planeta não pode alegar falta de recursos nesse caso. É um tapa na diplomacia internacional o governo americano levar criminosos de guerra a tribunais internacionais, como fez recentemente com o ex-presidente da Iugoslávia Slobodan Milosevic, ao mesmo tempo que veta o direito de outros países e organismos internacionais de processar seus próprios cidadãos. Ações como essa causam ressentimento. Mas seriam elas suficientes para atrair um atentado terrorista da magnitude do que destruiu as torres gêmeas? (não falam dos ataques e suporte a Israel) Só da perspectiva de lunáticos. Também não se pode sacar uma justificativa da conta de ressentimentos acumulados em meio século de Guerra Fria. Foi um período de ódios e transgressões, no qual o império soviético sempre se destacou como muito mais ousado em suas investidas contra a soberania de outros países. Há provavelmente sentimentos mais simples, menos reflexivos, na gênese do antiamericanismo que se observa nos salões dos letrados. "O antiamericanismo em Paris e Londres é resultado de um pouco de irracionalidade, modismo e ignorância mesmo”, diz o inglês Bryan Appleyard, autor de um artigo sobre o tema publicado pelo jornal londrino The Sunday Times e reproduzido no Brasil pelo jornal Estado de S. Paulo. Pode-se acrescentar outro ingrediente, a inveja pura e simples. Como lembra Appleyard, os Estados Unidos atualmente têm mais escritores, músicos e pensadores de projeção mundial do que todos os países da Europa. A cultura americana é dominante no mundo. E não apenas a cultura pop. "Os americanos são hoje os mais inteligentes, mais educados e cultos 
povos do planeta", escreveu o articulista inglês. "São pelo menos trinta as universidades americanas onde nossos melhores e mais brilhantes alunos seriam considerados medianos" Ele diz que o antiamericanismo se alimenta também da memória seletiva de seus cultores. Eles não deixam os pecados do passado morrer de velhos. Ao mesmo tempo, nunca se lembram das grandes conquistas humanitárias dos EUA no passado. Foram os caipiras da América que em três oportunidades no século que passou salvaram a refinada civilização européia do caos. Na I Grande Guerra, as tropas do general Pershing desempataram uma cruel luta de trincheiras em que toda uma geração de jovens europeus apodrecia entre o fogo e a gangrena. Na II Guerra, libertaram primeiro a França e a Itália e depois toda a Europa do nazi-fascismo. Em seguida, financiaram a reconstrução do continente com o Plano Marshall. Antes que o século acabasse, os americanos liquidaram, sem violência, outro regime bárbaro, o comunismo soviético. Claro que tais feitos não concedem imunidade eterna aos Estados Unidos. Pelo mesmo raciocínio, também seus erros passados não deveriam pairar sobre eles como uma condenação perpétua. Ao menos na hora do luto.

Tabela 9: Reportagem revista Veja edição 1720 - 3 de outubro de 2000.

\begin{tabular}{|l|l|}
\hline Discurso direto & $\begin{array}{l}\text { - Mark Hadley, professor de filosofia } \\
\text { norte-americano } \\
\text { - The Economist } \\
\text { - Anatol Lieven, norte-americano, } \\
\text { estudioso da Rand Corporation } \\
\text { - Jean-Marie Le Pen, politico francês } \\
\text { - Boris Fausto, historiador brasileiro } \\
\text { - Paul Krugman, economista norte- } \\
\text { americano } \\
\text { - Matthew Parris, político britânico } \\
- \text { Bryan Appleyard, jornalista britânico }\end{array}$ \\
\hline
\end{tabular}




\begin{tabular}{|c|c|}
\hline Discurso indireto & $\begin{array}{l}\text { - Boris Fausto, historiador brasileiro } \\
\text { - Bryan Appleyard, jornalista britânico }\end{array}$ \\
\hline Pressuposições existenciais & $\begin{array}{l}\text { - } o \text { antiamericanismo no Ocidente } \\
\text { - } o \text { uso político dessa ideologia } \\
\text { - os crimes cometidos pelos americanos } \\
\text { - da aversão aos americanos são mais } \\
\text { compreensíveis } \\
\text { - dos tiranos que os governam } \\
\text { - Nos mais radicais } \\
\text { - numa implosão monumental de } \\
\text { ineficiência e soberba } \\
\text { - } a \text { inveja pura e simples }\end{array}$ \\
\hline $\begin{array}{l}\text { Afirmações avaliativas/presunções } \\
\text { valorativas }\end{array}$ & 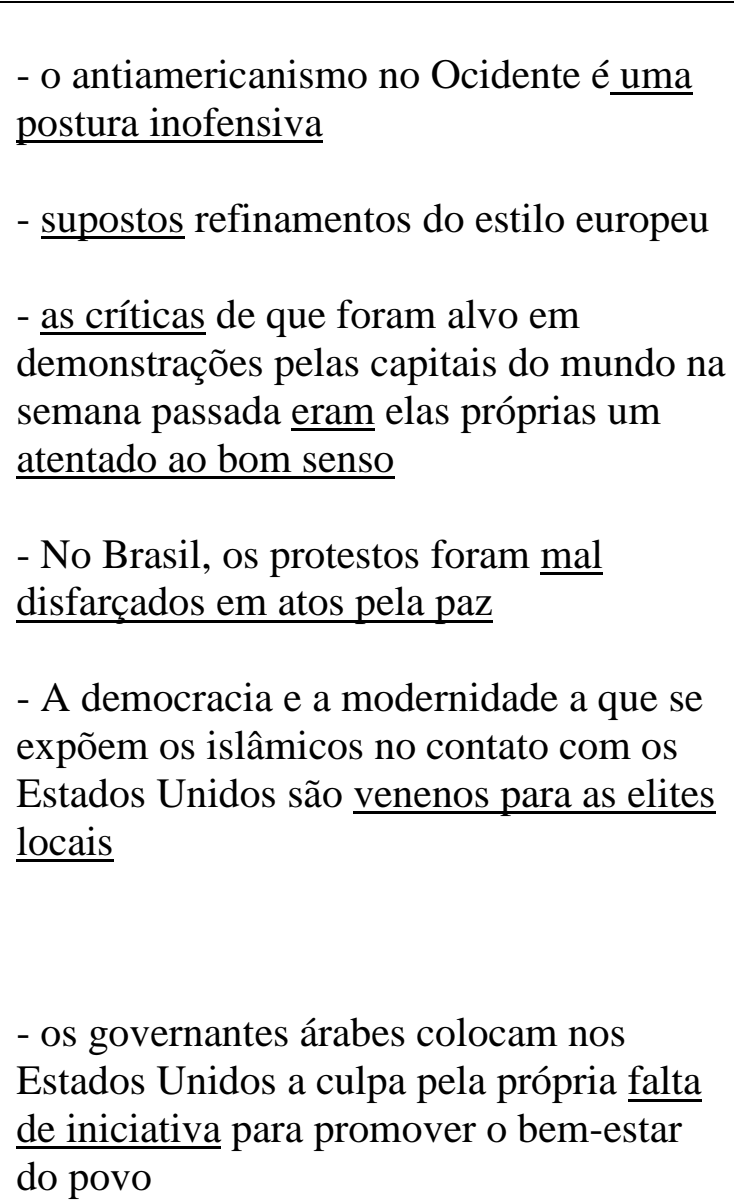 \\
\hline
\end{tabular}




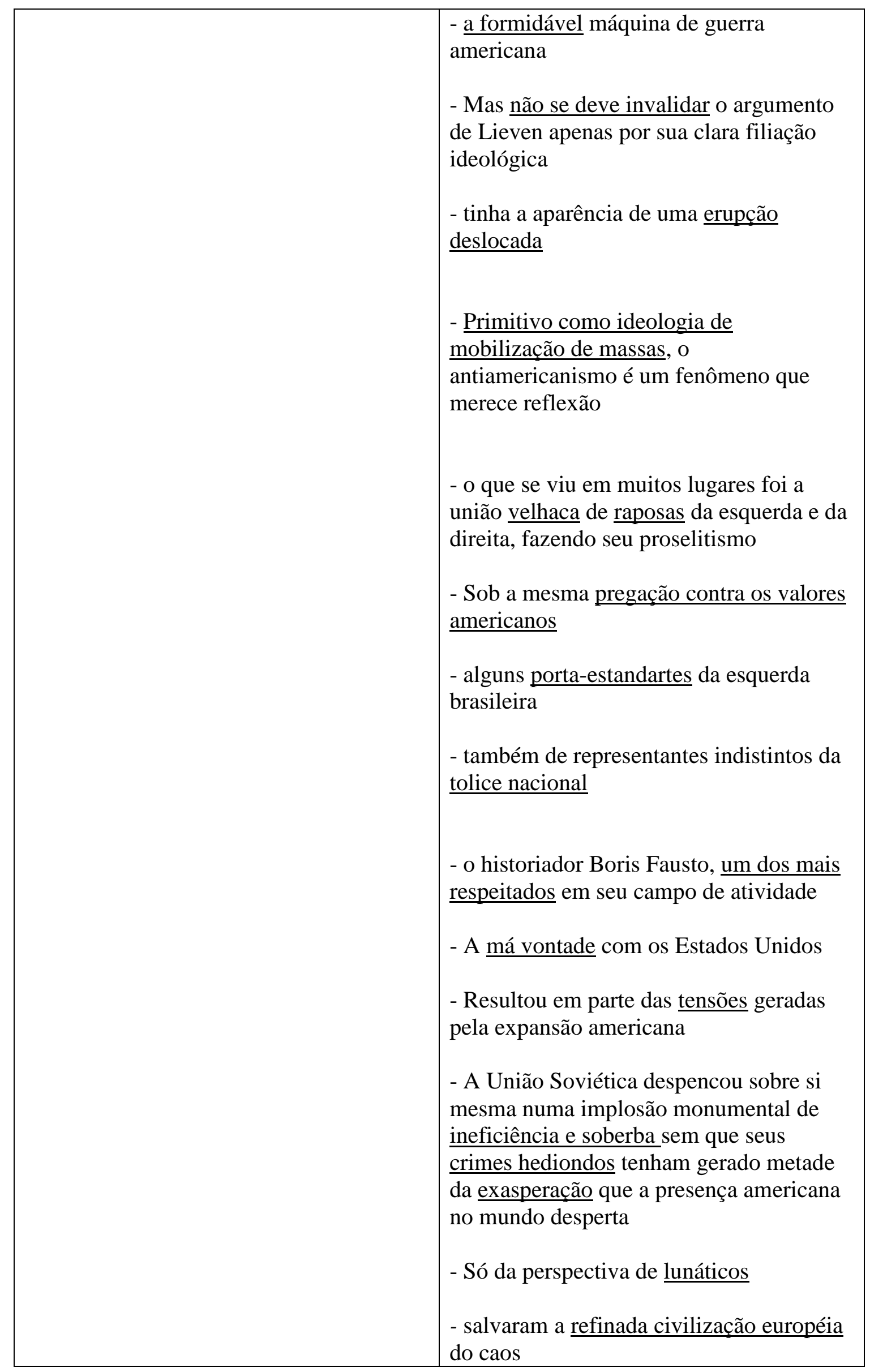




\begin{tabular}{|l|l|}
\hline & $\begin{array}{l}\text { - outro regime bárbaro, o comunismo } \\
\text { soviético }\end{array}$ \\
\hline & \\
\hline & \\
\hline
\end{tabular}

A reportagem expõe a contradição de Veja, que no texto "Ou estão do nosso lado ou do lado dos terroristas" afirmava a simpatia de todas as nações livres do mundo ao ataque de vingança dos Estados Unidos contra países que dariam suporte ao terrorismo internacional. A unidade textual "O vírus anti-EUA", no entanto, tem como mote central desqualificar argumentos e argumentadores contrários (que evidentemente existem) ao ataque militar que estava prestes a começar. Para observar essa estrutura, é preciso analisar as escolhas gramaticais realizadas por Veja.

O texto classifica posições antiamericanas como inofensivas. Em uma análise superficial, o adjetivo pode parecer significar apenas "algo que não é ofensivo", "que não faz mal", "que não escandaliza", como apontam os dicionários ${ }^{65}$. No entanto, no contexto da reportagem, o adjetivo ganha conotação de ingenuidade, próximo da infantilização. Prova disso está na contraposição realizada na sequência, quando a revista diz que o uso político dessa ideologia perdeu a inocência de que habitualmente se reveste. O texto trabalha para convencer o leitor de que todos os países deveriam apoiar os ataques, uma vez que os atentados resultaram no assassinato de milhares de trabalhadores, predominantemente americanos, mas também de dezenas de outras nacionalidades. Os atos americanos ao redor do globo são suavizados, tidos apenas como erros ou até crimes. O uso do advérbio até é estratégico. Com ele, Veja não dá como certo que tenham sido crimes. $\mathrm{O}$ até serve para dar a ideia de possibilidade remota, a impressão de que até pode ter acontecido algum crime, mas isso é discutível, na percepção da revista. Já no caso da União Soviética, citada mais adiante no texto, $\underline{\text { seus crimes são classificados de hediondos. }}$.

Veja desconfia dos propósitos dos atos, mal disfarçados em atos pela paz, e um atentado ao bom senso. Bom-senso que, de acordo com a revista, deve se esperar, sim, dos ocidentais, mas não dos cidadãos de países de maioria islâmica, pois entre os povos árabes e outras etnias que seguem o islamismo, as causas da aversão aos americanos são

\footnotetext{
${ }^{65}$ Disponível em: <http://michaelis.uol.com.br/moderno/portugues/index.php?lingua=portuguesportugues\&palavra=inofensivo $>$.
} 
mais compreensíveis. Deles também não devemos esperar qualquer posicionamento crítico e independente, uma vez que são jovens pauperizados e sem esperança de progresso material (que) ouvem dos tiranos que os governam que a causa de sua miséria é externa. Dos ocidentais deveríamos esperar bom-senso e, por isso, Veja questiona o motivo para o que ela chama de aversão ao modo de vida americano. A revista também faz clara diferenciação de posicionamentos dos que estão ao "nosso" lado ou do lado dos "outros". Uma das vozes utilizadas em discurso direto no texto é a de $\underline{\text { Anatol }}$ Lieven, um estudioso americano da Rand Corporation, instituição semi-oficial que há décadas assessora sucessivos governos americanos na área estratégica e foi instrumental durante os anos da Guerra Fria. Segundo a revista, não se deve invalidar o argumento de Lieven apenas por sua clara filiação ideológica. A palavra direita é escondida, o que não acontece quando o exemplo é o político francês Jean-Marie Le Pen, um racista declarado classificado como líder da extrema direita francesa. A colocação no espectro ideológico está sempre presente para classificar os que são contrários aos ataques, como alguns porta-estandartes da esquerda brasileira e também representantes indistintos da tolice nacional. Nenhum desses representantes, ou porta-estandartes, ganhou voz no texto. Apenas os que apresentam o discurso que coincide com a posição de Veja, como o historiador Boris Fausto, um dos mais respeitados em seu campo de atividade. Entre os porta-estandartes da esquerda brasileira só há tolice, nenhuma respeitabilidade, de acordo com a publicação.

Por último, Veja, sem que seus leitores sejam alertados, reproduz um parágrafo da edição de 20 de setembro de 2001 da revista The Economist. ${ }^{66} \mathrm{O}$ texto na revista britânica, publicado na íntegra na sequência, diz:

"The charge that in politics the United States is arrogant, even hypocritical, may deserve more notice. America has recently brushed aside some good international agreements (on nuclear testing, for example, a world criminal court, land mines), as well as dismissing some bad ones (the Kyoto convention on global warming) with an insouciance unbecoming to the world's biggest producer of greenhouse gases. Its understandable determination to pursue a missile shield threatens to upend the system of deterrence and arms control that has so far saved the world from nuclear Armageddon. It has refused to pay its dues to the United Nations, even as it has cut its aid for the world's poorest. Its eagerness to prosecute African and Balkan war

\footnotetext{
${ }^{66}$ Disponível em: <http://www.economist.com/node/788407>.
} 
criminals while refusing to allow its own nationals to submit to an international court has made it seem unwilling to hold itself to the standards it imposes on others. Were these actions unwise? Possibly. Have they caused resentment? Yes. But could that resentment plausibly have motivated a single one of last week's suicide attackers? No." Em Veja: “Os Estados Unidos com frequência são ainda arrogantes e até hipócritas. As posições recentes dos americanos renegando acordos internacionais de proteção ecológica, como o de Kioto, aliadas ao fato de serem eles os maiores produtores de gases poluentes do planeta, certamente não atraem simpatia. A recusa em bancar suas obrigações financeiras como membros da Organização das Nações Unidas, a ONU, soa para muita gente um desprezo para com a comunidade internacional. A nação mais rica do planeta não pode alegar falta de recursos nesse caso. É um tapa na diplomacia internacional o governo americano levar criminosos de guerra a tribunais internacionais, como fez recentemente com o ex-presidente da Iugoslávia Slobodan Milosevic, ao mesmo tempo que veta o direito de outros países e organismos internacionais de processar seus próprios cidadãos. Ações como essa causam ressentimento. Mas seriam elas suficientes para atrair um atentado terrorista da magnitude do que destruiu as torres gêmeas? Só da perspectiva de lunáticos." 


\section{The roots of hatred}

Whatever its mistakes, the idea that America brought the onslaught upon itself is absurd

WHO is to blame? The simple answer - the suicide attackers, and those behind them - is hardly adequate, just as it would hardly be adequate simply to blame Hitler and his henchmen for the second world war, without mentioning the Treaty of Versailles or Weimar inflation. But that does not exculpate the perpetrators of last week's onslaught, just as the Versailles treaty does not excuse Auschwitz: whatever their grievances, nothing could excuse an attack of such ferocity and size. So what explains it? A surprising number of people, and not just gullible fanatics looking for someone to hold responsible for the hopelessness of their lives, believe that to a greater or lesser extent America has reaped as it sowed.

If this charge is to be taken at all seriously, it must first be separated from the general anti-Americanism fashionable in some left-wing circles in Europe, say, or even Latin America. It may be reasonable to dislike the death penalty, a society so ready to tolerate guns, even the vigour of a culture that finds its expression in unpretentious movies and McDonald's hamburgers, but none of these could conceivably explain, let alone justify, a single act of terrorism. Similarly, though globalisation clearly arouses fury among protesters, and concern among some more moderate critics, it would be ridiculous to think that last week's attack was prompted by any American antipathy towards welfare payments, closed economies or restraints on speculative capital movements.

The charge that in politics the United States is arrogant, even hypocritical, may deserve more notice. America has recently brushed aside some good international agreements (on nuclear testing, for example, a world criminal court, land mines), as well as dismissing some bad ones (the Kyoto convention on global warming) with an insouciance unbecoming to the world's biggest producer of greenhouse gases. Its understandable determination to pursue a missile shield threatens to upend the system of deterrence and arms control that has so far saved the world from nuclear Armageddon. It has refused to pay its dues to the United Nations, even as it has cut its aid for the world's poorest. Its eagerness to prosecute African and Balkan war criminals while refusing to allow its own nationals to submit to an international court has made it seem unwilling to hold itself to the standards it imposes on others. 
Were these actions unwise? Possibly. Have they caused resentment? Yes. But could that resentment plausibly have motivated a single one of last week's suicide attackers? No.

\section{The seeds of discord}

Perhaps it would be more profitable to look deeper into the past. During the halfcentury of the cold war, the United States undoubtedly subordinated principles as well as causes to the overriding concern of defeating communism. The great upholder of laws at home was happy to trash them abroad, whether invading Grenada or mining Nicaraguan harbours. It propped up caudillos in Latin America, backed tyrants in Africa and Asia, promoted coups in the Middle East. More recently, it has been willing to kick invaders out of Kuwait, to strike at ruthless states like Libya and Iraq and, moreover, to go on trying to contain them with sanctions and, in Iraq's case, with almost incessant bombardment. Is it here perhaps - especially in the Middle Eas $t$ that America has gone wrong?

No. The Economist has not been an uncritical supporter of American policy in the Middle East. We have been more ready to argue the Palestinian case than have recent administrations and believe that the United States could sometimes have done more to restrain Israel. We have also pointed out that the policy of sanctions against Iraq, whatever its intention, in practice punishes innocent Iraqis and thus allows Saddam Hussein to blame the West, notably America, for the deaths of thousands of Iraqi children. Perhaps nothing does more to fuel anti-American resentment in the Arab world. Such criticisms as we have made, however, in no way imply that we think America was wrong to fight the Gulf war or to try to disarm Saddam afterwards. It was also right to stand by Saudi Arabia as an ally, however much that annoyed zealots. Similarly, whatever Israel's mistakes, America can hardly be accused of having failed to try to bring it to a peace: every administration of recent years has attempted to bring the two sides together, and none has come closer than Bill Clinton's last year.

America defends its interests, sometimes skilfully, sometimes clumsily, just as other countries do. Since power, like nature, abhors a vacuum, it steps into places where disorder reigns. On the whole, it should do so more, not less, often. Of all the great powers in history, it is probably the least territorial, the most idealistic. Muslims in particular should note that the armed interventions in Bosnia and Kosovo, both led by America, were attacks on Christian regimes in support of Muslim victims. In neither did the United States stand to make any material gain; in neither were its vital interests, conventionally defined, at stake. Those who criticise America's leadership of the world's 
capitalist system - a far from perfect affair — should remember that it has brought more wealth and better living standards to more people than any other in history. And those who regret America's triumph in the cold war should stop to think how the world would look if the Soviet Union had won. America's policies may have earned it enemies. But in truth, it is difficult to find plausible explanations for the virulence of last week's attacks, except in the envy, hatred and moral confusion of those who plotted and perpetrated them. 
Texto 10: Reportagem revista Veja edição 1720 - 3 de outubro de 2001.

\section{QUANDO A GUERRA É JUSTA}

Os atentados terroristas contra os Estados Unidos abriram caminho a um tipo peculiar de obtusidade moral. Corpos sem cabeça e cabeças sem corpo ainda cobriam as calçadas de Nova York, vítimas inocentes estavam morrendo nos hospitais dentre os poucos sobreviventes transformados em tochas humanas, pais e mães se horrorizavam ante a idéia das criancinhas pulverizadas nos aviões dominados pelos fanáticos suicidas - e uma pergunta já rondava muitas mentes: "O que será que os Estados Unidos vão fazer agora?" A partir dessa indagação, saltou-se para a conclusão de que a superpotência desfecharia uma reação arrasadora, indiscriminada. E, daí, em muitos casos, para marchas e passeatas em favor da paz, invariavelmente marcadas por uma confusão conceitual na qual a "guerra" (a resposta americana à agressão, que possivelmente nem terá o formato de um confronto convencional) é colocada no mesmo nível que o terrorismo, quando não considerada pior ainda. $O$ uso de crianças inocentes, de artistas de cabeça oca e de ingênuos em geral não obscureceu um fato: no estado de embotamento propiciado por tal inversão de valores, praticamente desapareceram as manifestações de pesar, como o mais elementar sentimento de humanidade, pelas mais de 6.000 pessoas imoladas na fúria terrorista. As pessoas que se opõem tanto a uma operação militar podem ser divididas em dois grupos. No primeiro, alinham-se aqueles que, habituados a uma automática reação antiamericana, não conseguem conceber uma situação na qual a superpotência seja vítima, não perpetradora, de um crime. Por esse caminho é que se chega à conclusão indecente de que os americanos, em geral, fizeram por merecer os ataques hediondos. O segundo grupo abriga os bem-intencionados e mal informados, os que consideram que toda guerra é intrinsecamente má e deve ser combatida a qualquer preço. A reação automática de apelar "pela paz" é compreensível. O problema é que a desinformação contribui para alimentar a aflição popular. Segundo uma pesquisa conduzida pelo Instituto Sensus, por encomenda da Confederação Nacional do Transporte, 79,1\% dos brasileiros entrevistados acham que vai haver uma guerra mundial, 23,6\% atribuem os atentados, comandados pelo milionário Osama bin Laden, a conflitos econômicos e outros $23,1 \%$ pôem a culpa em questões raciais.

A essas boas almas, 
monsenhor Joaquín Navarro Valls, o porta-voz do papa João Paulo II, dirigiu um chamado à razão na semana passada. "Se alguém causou um grande dano à sociedade e se existe o risco de que, continuando livre, possa voltar a fazê-lo, impõe-se aí o direito à autodefesa, ainda que este implique o uso de meios que possam ser agressivos", disse ele. O estilo é sinuoso, mas o significado é claro: do ponto de vista da Igreja, uma reação armada americana é legítima, ressalvados, obviamente, o princípio da proporcionalidade e o esforço de preservação da integridade física dos inocentes. Se restava alguma dúvida quanto à posição do Vaticano, Navarro Valls disparou o último míssil: "Às vezes, é mais prudente reagir do que ser passivo. Nesse sentido, o papa não é um pacifista, pois é preciso notar que, em nome da paz, foram cometidas muitas injustiças". O porta-voz do papa tomou o cuidado de não usar o termo guerra justa, considerado ultrapassado pelos estudiosos, embora seja um conceito existente desde a Antiguidade clássica, recuperado por sábios da Igreja, como Santo Agostinho e Santo Tomás de Aquino (e muitas vezes invocado indevidamente, para justificar abusos). À luz da tradição humanista da Igreja e dos princípios da ética cristã hoje vigentes, no entanto, as palavras do porta-voz do papa têm um peso extraordinário. Não é todo dia que o Vaticano endossa o recurso à força - e relembra, sutilmente, a chaga aberta pela política de apaziguamento em relação à Alemanha nazista. Despreparadas diante do furor belicista de Hitler, Inglaterra e França tentaram aplacá-lo. Ofereceram, primeiro, a entrega de metade da região conhecida como Sudetos, com população majoritariamente alemã, no que era a Checoslováquia da época. Hitler tomou os Sudetos inteiros. Depois, a Checoslováquia inteira. Sem disparar um só tiro. O Pacto de Munique, que selou a vergonhosa rendição, entrou para a História como sinônimo da inutilidade das tentativas de negociar com tiranos - e de desonra para os homens que chancelaram.

Os horrores produzidos pelas duas grandes guerras do século XX $(26$ milhões de mortos na primeira, 50 milhões de mortos na segunda) levaram a comunidade internacional a regular estritamente o recurso à violência. O exercício da força de um Estado contra outro é governado, do ponto de vista do direito internacional, pela Carta das Nações Unidas. A linguagem extremamente cautelosa do artigo 51 estabelece: "Nada na presente Carta prejudicará o direito inerente de legítima defesa individual ou coletiva no caso de ocorrer um ataque armado contra um membro das Nações Unidas”. Em linguagem popular, isso significa que um país agredido tem o direito 
natural

de

revidar

para

se

defender.

Não é preciso ser pró-americano para aceitar a legitimidade de uma resposta armada dos Estados Unidos aos autores dos atentados de Nova York e Washington. Nem é preciso, por causa disso, ignorar as notórias deficiências da política externa americana, especialmente no Oriente Médio. Também não é necessário fechar os olhos às injustiças sofridas pelo povo palestino ou deixar de se preocupar com o destino dos pobres afegãos, arrastados para o centro de um conflito internacional por obra de um bando de fanáticos. Essas coisas são perfeitamente compatíveis entre si. Embora o direito à autodefesa pareça auto-explicativo, ainda assim há espaço para uma posição contrária. "Na análise das relações internacionais, existem duas correntes de pensamento que se contrapõem: a realista e a idealista. A segunda entende que todo conflito deve ser solucionado por meio de fórmulas negociadas e que a guerra é uma imoralidade e uma aberração por princípio”, explica Alcides Costa Vaz, professor do departamento de relações internacionais da Universidade de Brasília. O pacifismo é um movimento digno de todo o respeito, especialmente pela coragem que requer de seus praticantes. Se, por hipótese, se fica sabendo que os terroristas de Osama bin Laden pretendem atacar determinados alvos, digamos, embaixadas americanas, os pacifistas de verdade se veriam na obrigação moral de fazer uma corrente humana em torno desses prédios, dar-se as mãos e esperar que, por meio desse supremo exemplo de desprendimento, Laden desistisse de transformá-los em tochas humanas. Quem, desde já, se candidatar adquire incontestavelmente o direito de aconselhar os Estados Unidos a não reagir ao massacre de 6.000 cidadãos.

Tabela 10: Reportagem revista Veja edição 1720 - 3 de outubro de 2001.

\begin{tabular}{|l|l|}
\hline Discurso direto & $\begin{array}{l}\text { - Joaquín Navarro Valls, porta-voz do } \\
\text { papa João Paulo II }\end{array}$ \\
- Carta das Nações Unidas \\
& $\begin{array}{l}\text { - Alcides Costa Vaz, professor do } \\
\text { departamento de relações internacionais } \\
\text { da Universidade de Brasília }\end{array}$ \\
\hline Discurso indireto & \\
\hline Pressuposições existenciais & \\
\hline
\end{tabular}




\begin{tabular}{|c|c|}
\hline & $\begin{array}{l}\text { - } a \text { desinformação contribui para alimentar } \\
\text { a aflição popular } \\
\text { - } a \text { legitimidade de uma resposta armada } \\
\text { dos Estados Unidos }\end{array}$ \\
\hline $\begin{array}{l}\text { Afirmações avaliativas/presunções } \\
\text { valorativas }\end{array}$ & $\begin{array}{l}\text { - um tipo peculiar de obtusidade moral } \\
\text { - Quando a guerra é justa } \\
\text { - artistas de cabeça oca e de ingênuos em } \\
\text { geral } \\
\text { - se chega à conclusão indecente } \\
\text { - O segundo grupo abriga os bem- } \\
\text { intencionados e mal informados } \\
\text { - dirigiu um chamado à razão } \\
\text { - sábios da Igreja } \\
\text { - as palavras do porta-voz do papa têm um } \\
\text { peso extraordinário }\end{array}$ \\
\hline
\end{tabular}

O texto, como se evidencia no título, tem como meta convencer os leitores de que um ataque militar norte-americano é legítimo e necessário, ainda que nessa unidade textual Veja não aponte exatamente quem deva ser atacado. Para dar suporte aos seus argumentos, a revista utiliza como método a desqualificação dos opositores da ideia de uma ofensiva militar, utilizando em alguns momentos a ironia como suporte para tal, e, especialmente, deixando de fora aspectos importantes para a construção do contexto: "what is 'said' in a text is 'said' against a background of what is 'unsaid', but taken as given" (FAIRCLOUGH, 2003, p. 40) ${ }^{67}$.

Veja diz que os atentados abriram caminho a um tipo peculiar de obtusidade moral, que vem a ser, na visão da revista, marchas e passeatas em favor da paz com a participação de crianças inocentes, de artistas de cabeça oca e de ingênuos em geral. Nesse sentido, obtusidade

\footnotetext{
67 “o que é dito em um texto é dito contra um segundo plano do que não é dito, mas assumido como um fato dado"
} 
moral se apresenta como eufemismo para estúpido, ignorante, incapaz de aprender algo, que são as definições para o adjetivo obtuso ${ }^{68}$. A revista também divide o grupo que se opõe aos ataques norte-americanos em dois grupos, os bem-intencionados mas mal informados e os que não conseguem conceber uma situação na qual a superpotência seja vítima, não perpetradora, de um crime. Esses, segundo Veja, acreditam que os Estados Unidos fizeram por merecer os ataques hediondos, o que seria uma conclusão indecente, ou seja, indecorosa ou desonesta ${ }^{69}$. Portanto, quem contraria a visão defendida pela revista ou é desonesto ou mal informado. Uma contraposição é estabelecida, começando com a declaração do porta-voz do Vaticano, Joaquín Navarro Valls - apresentado como $\underline{\text { monsenhor pela revista, apesar de não ser sacerdote - classificada como um chamado à }}$ razão. Os santos católicos são sábios da Igreja. Veja também diz que não é todo dia que o Vaticano endossa o recurso à força - e relembra, sutilmente, a chaga aberta pela política de apaziguamento em relação à Alemanha nazista. No exercício de pensar o que é dito e o que fica de fora na construção de um texto, ficam evidentes as escolhas feitas pela publicação brasileira sobre o que revelar e o que deixar de fora na construção de seus argumentos. Nessa unidade textual e nesse contexto, Veja escolheu não relembrar o passado de "intolerância, opressão e corrupção" da Igreja Católica, tendo entre seus pecados "guerras religiosas", entre elas "as cruzadas e a Inquisição" e "a depreciação contra o povo judeu e [...] papel ambíguo da Santa Sé durante a perseguição nazista aos judeus na Segunda Guerra Mundial”, pelos quais o Papa João Paulo II se desculpou no ano de 2000, como já afirmou a própria revista ${ }^{70}$. Veja dá voz diretamente a Alcides Costa Vaz, professor do departamento de relações internacionais da Universidade de Brasília, para que ele explique que na análise das relações internacionais, existem duas correntes de pensamento que se contrapõem: a realista e a idealista. A segunda entende que todo conflito deve ser solucionado por meio de fórmulas negociadas e que a guerra é uma imoralidade e uma aberração por princípio. A declaração é utilizada como suporte para que a revista desqualifique a linha de pensamento que a contraria. Veja diz que se, por hipótese, se fica sabendo que os terroristas de Osama bin Laden pretendem atacar determinados alvos, digamos, embaixadas americanas, os pacifistas de verdade se veriam na obrigação moral de fazer uma corrente humana em torno desses prédios, dar-

\footnotetext{
${ }^{68}$ Disponível em: <http://michaelis.uol.com.br/moderno/portugues/index.php?lingua=portuguesportugues\&palavra $=$ obtuso $>$.

${ }^{69}$ Disponível em: <http://michaelis.uol.com.br/moderno/portugues/index.php?lingua=portuguesportugues\&palavra=indecente $>$.

${ }^{70}$ Disponível em: <http://veja.abril.com.br/150300/p_057.html>.
} 
$\underline{\text { se as mãos e esperar que, por meio desse supremo exemplo de desprendimento, Laden }}$ $\underline{\text { desistisse de transformá-los em tochas humanas. Segundo a revista, apenas esses terão o }}$ direito de aconselhar os Estados Unidos a não reagir ao massacre de 6.000 cidadãos.

Texto 11: Reportagem revista Veja edição 1721 - 10 de outubro de 2001.

\section{O CERCO AOS HOMENS DAS CAVERNAS}

Uma estranha questão está colocada sobre a mesa dos estrategistas do Pentágono: como a superpotência, munida das armas mais sofisticadas que existem, deve combater uma milícia do Quarto Mundo cujo principal trunfo é a habilidade com que se esconde em cavernas? Batalhas travadas com muçulmanos fanáticos em estreitas galerias escavadas no arenito das montanhas afegãs são quase inevitáveis caso as forças americanas se aproximem do grande prêmio: a captura, vivo ou morto, de Osama bin Laden, o chefão do terrorismo islâmico. Túneis e Laden compõem, pode-se dizer, o mesmo cenário. Assim que chegou ao Afeganistão, em 1979, para lutar contra os soviéticos, o milionário saudita decidiu usar sua fortuna e experiência como engenheiro para ampliar, conectar e fortificar as cavernas que já vinham sendo utilizadas como abrigo pelos mujahidim, os guerrilheiros islâmicos. Laden mandou buscar caminhões e maquinaria pesada da empreiteira de sua família na Arábia Saudita e deu início à construção de fortalezas encravadas em rocha pura. Estima-se que só na Cordilheira do Hindu Kush, na região central do Afeganistão, exista uma complexa rede de 10000 cavernas. É quase irônico que os responsáveis pela destruição do World Trade Center, símbolo da modernidade e da prosperidade econômica, acabem caçados em tocas, como trogloditas pré-históricos.

O uso militar de cavernas é uma tradição afegã. Nos anos 80, naturais ou abertas pelos guerrilheiros, elas serviam de posto de observação e de espera para emboscar os soldados soviéticos. Era de dentro dessas trincheiras que os guerrilheiros dispavaram os mísseis Stinger, fornecidos pela CIA, de efeito tão devastador contra os helicópteros e aviões da União Soviética. Depois da guerra, os Estados Unidos ofereceram 100.000 
dólares por cada Stinger devolvido, mas estima-se que pelo menos 100 deles tenham sido guardados como troféus por chefes tribais. Nada se compara ao furor obsessivo com que Laden se pôs a construir trincheiras, abrigos subterrâneos e a escavar túneis nos anos 90. Ele não poupou dinheiro para terminar uma série de complexos fortificados em vários pontos do país. Cada uma dessas bases é guardada por metralhadoras e artilharia antiaérea. Um assalto para tirar os terroristas das tocas exigiria bombardeios pesados, incluindo o uso de mísses capazes de penetrar a rocha. A seguir, forças especiais precisariam infiltrar-se nas galerias para o que seria literalmente uma luta corpo a corpo. A experiência mais parecida com isso ocorreu nos túneis cavados pelos guerilheiros comunistas do Vietnã - mas esses não eram tão extensos, largos e profundos nem tão bem defendidos como os do saudita Laden. Em que momento começará a batalha dos túneis, para a qual, dizem os jornais londrinos, os soldados da SAS inglesa e das forças especiais americanas estão treinando intensamente? O que se pode dizer é que na semana passada, quase um mês depois dos atentados de 11 de setembro, a campanha antiterrorista finalmente parece ter chegado à fase militar. Não apenas as forças mobilizadas para a guerra se postaram em torno do Afeganistão para o ataque como os alvos prioritários dos bombardeios já estão escolhidos. São uma dúzia de campos de treinamento da Al Qaeda, a organização de Laden (entre elas a célebre área da Brigada 055, na qual se acredita que sejam treinados os terroristas suicidas), cinco ou seis bases aéreas e guarnições com tropas do Talibãa. Há também usinas elétricas, equipamentos de comunicação e lugares onde se armazena combustível. Em Washington e Londres, o presidente George W. Bush e o primeiro-ministro Tony Blair fizeram pronunciamentos que soaram como chamados às armas. Ao exibir as provas contra o terrorista saudita, Blair afirmou que o Talibã e Osama bin Laden são "dois lados da mesma moeda. Osama não poderia existir no Afeganistão sem o Talibã e o Talibã não poderia existir sem Osama”. A mensagem é claríssima: não há mais tempo ou disposição para negociar com a milícia de fanáticos islâmicos que controla quase todo o território do Afeganistão e protege o terrorista saudita. O Talibã será destruído junto com a organização de Laden.

O que até semana passada segurava o gatilho era a necessidade de amarrar pontas soltas na coalização internacional. O secretário da Defesa americano, Donald Rumsfeld, partiu em visita à Arábia Saudita, Omã, Egito e Uzbequistão. Sua missão era convencer esses aliados nervosos a conceder apoio militar e logístico. Na hora em que precisam ir além do apoio verbal, essas nações não hesitam, com medo de provocar a 
fúria de seus próprios fundamentalistas. A monarquia saudita prometeu cooperar com os americanos, mas, pelo menos em público, insistiu que não vai permitir o uso de seu território como ponto de partida para ataques a outros países muçulmanos. Na verdade, em nenhum desses países Rumsfeld obteve carta branca para agir. Até o momento, a mais promissora base disponível é o Uzbequistão, país que tem problemas com seus próprios fundamentalistas. Na semana passada, admitiu-se o envio dos primeiros 1.000 soldados americanos para lá. O esforço para cativar o mundo muçulmano azedou as relações com um aliado tradicional, Israel. Irritado com a insistência americana por trégua no conflito com os palestinos, na quinta-feira, o primeiro-ministro Ariel Sharon advertiu aos Estados Unidos, em tom agressivo, que não tentem "chegar a um acordo com os árabes em detrimento de Israel”. Com rispidez inusitada, a Casa Branca qualificou as palavras de Sharon como “inaceitáveis". Nesse ambiente tenso, só faltava a explosão misteriosa de um avião russo, que partira de Tel-Aviv com 76 pessoas a bordo. É bem possível que tenha sido atingido acidentalmente por um míssil disparado em exercícios militares na Ucrâniamas a suspeita de novo terrorismo aéreo injetou nova onda de tensão. Com a máquina de guerra bem azeitada, os Estados Unidos tiveram fôlego para se dedicar a outra questão: organizar como será a vida do Afeganistão depois da destruição do Talibã. Na última semana, até o governo do Paquistão, o único que ainda mantém um canal diplomático com os fundamentalistas de Cabul, admitiu que os dias da milícia estão contados. Uma das dores de cabeça dos aliados da coalização antiterrorista é como pacificar o Afeganistão de modo que deixe de ser um terreno fértil para o surgimento e treinamento de terroristas. A saída mais atraente no horizonte é a Aliança do Norte, que representa a única oposição organizada ao Talibã. Uma coligação de forças diversas reúne talvez 15.000 guerrilheiros e controla cerca de $10 \%$ do território afegão. Há um problema óbvio nessa solução. Esses combatentes são recrutados nas etnias minoritárias - tadjiques, uzbeques e hazarás -, enquanto foi entre os patanes, a majoritária, que surgiu o Talibã. Dado o peso das rivalidades tribais, é quase impossível que o Afeganistão seja unificado por essas etnias minoritárias. Há outro problema. A Aliança do Norte tem um passado terrível. No governo até 1996, arruinou o país com rixas sangrentas entre facções, saques e massacres generalizados. A situação era tão ruim que os afegãos respiraram aliviados com a chegada do puritanismo talibã - pelo menos por algum tempo. Para ter alguma chance, a Aliança precisaria se expandir, incluindo maior número de patanes. 
Se alguém pode iniciar um movimento de colagem do mosaico afegão é o patane Mohamed Zahir Shah, o rei exilado. Aos 86 anos, ele vive em Roma há quase três décadas e já disse que nem pensa no retorno da monarquia. Mas, depois de um encontro com líderes da Aliança do Norte há uma semana, Zahir aceitou retornar a Cabul e convocar uma Loya Jirga, assembléia de líderes religiosos e tribais. O país também não tem boas recordações da monarquia, que foi violenta e instável. O criador do Afeganistão moderno, Abdor Rahman, que reinou de 1880 a 1901, foi o único a comandar sem golpes. Os quatro reis seguintes foram assassinados. Zahir Shah, que criou uma monarquia constitucional, com eleições e partidos, foi derrubado por um primo, em 1973. Na verdade, o rei que querem trazer de volta nunca governou. Primeiro, muito jovem, foi tutelado por tios. Depois, por primeiros-ministros eleitos. Daí veio a imagem de bonachão, de um governante sem gosto pelo poder, que desfruta entre seu povo. Um rei bonachão? Que alívio não seria para os afegãos depois de uma tirania de Omar, o mulá de um só olho que manda açoitar as mulheres, proibiu a música, o jogo de cartas e deu abrigo a terroristas internacionais.

Tabela 11: Reportagem revista Veja edição 1721 - 10 de outubro de 2001.

\begin{tabular}{|l|l|}
\hline Discurso direto & - Tony Blair, primeiro-ministro britânico \\
& - Ariel Sharon, primeiro-ministro de Israel \\
& - Casa Branca \\
\hline Discurso indireto & $\begin{array}{l}\text { - George W. Bush, presidente norte- } \\
\text { americano }\end{array}$ \\
\hline Pressuposições existenciais & governo do Paquistão \\
& $\begin{array}{l}\text { - uma tirania de Omar, o mulá de um só } \\
\text { olho } \\
\text { - O esforço para cativar } o \text { mundo } \\
\text { muçulmano }\end{array}$ \\
\hline Afirmações avaliativas/presunções & - Cerco aos homens das cavernas \\
\hline
\end{tabular}




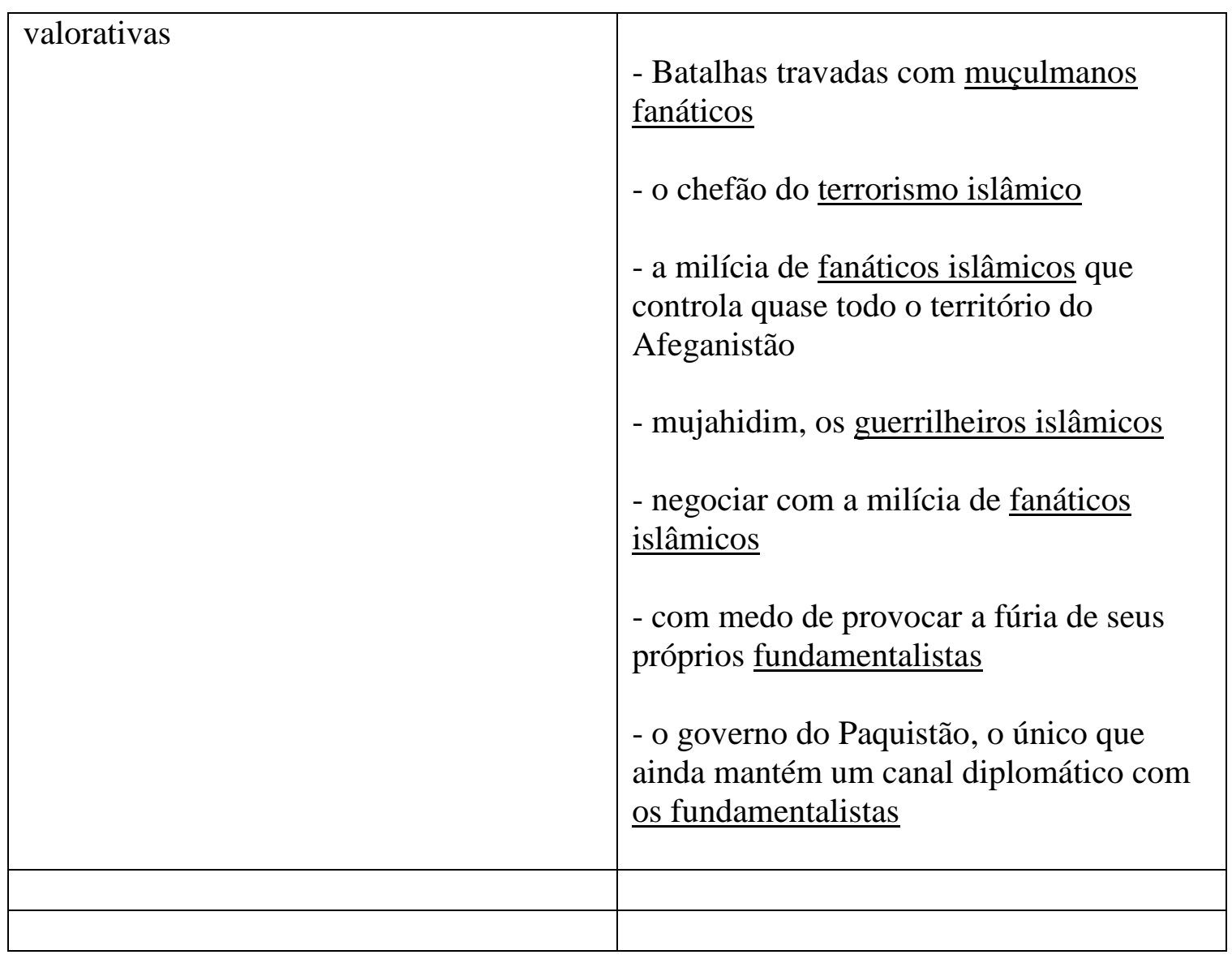

O texto "O cerco aos homens das cavernas" repete operações verificadas em unidades textuais anteriores. Uma delas é a utilização de sintagmas nominais, quando diz que serão quase inevitáveis batalhas travadas com muçulmanos fanáticos; quando classifica Osama bin Laden de chefão do terrorismo islâmico; quando aponta os mujahidim como guerrilheiros islâmicos; quando afirma que não há mais tempo ou disposição para negociar com a milícia de fanáticos islâmicos. Como já visto neste trabalho, Said (1997, p. XV-Xvi) diz se preocupar com a possibilidade do uso de rótulos serem utilizados como uma forma de ataque que gera hostilidade e lembra que "Islã" define uma relativamente pequena proporção do que acontece no mundo islâmico, formado por dúzias de países, sociedades, tradições, linguagens, além de um número infinito de experiências. Isabelle Castro (2007, p. 68-69) analisou o uso de sintagmas nominais com modificadores para islâmicos em reportagens sobre o Talibã nos jornais Folha de S.Paulo e O Estado de S. Paulo. Segundo ela, essa operação "reforça a ideia de que o Talibã é um representante do Islã em geral e não uma parte muito ínfima dentro do universo de mais de 1,5 bilhão de fiéis". Citando pesquisa conduzida por especialistas da American Academy of Arts and Sciences, que realizaram estudos para 
definir a unidade lexical fundamentalismo, e a revisão que Lustick fez do trabalho, quando apontou que fundamentalismo não deveria ser definido, Said (1997, p. xvii) diz que se especialistas são incapazes de chegar a essa definição, o que pensar de um grupo de "polemicist - spurred onward by zeal and a hostility to all things Muslim" ${ }^{71}$. O sucesso foi conseguido, no entanto "in stirring up feelings of alarm and consternation in their readers". 72

A unidade textual também repete operação observada em outros textos quando evita o contraditório e aceita como fato dado o discurso dos aliados Estados Unidos e Inglaterra de que não há mais tempo ou disposição para negociar com a milícia de fanáticos islâmicos que controla quase todo o território do Afeganistão e protege o terrorista saudita. O Talibã será destruído junto com a organização de Laden. Como nos textos anteriores, Veja escolheu dar voz direta apenas a representantes do país que esteve à frente dos ataques com os Estados Unidos, a Inglaterra, e o aliado tradicional, Israel.

Texto 12: Reportagem revista Veja edição 1721 - 10 de outubro de 2001.

\section{INTELECTUAIS EM GUERRA}

A guerra está sendo dura e suja. Travada diante dos teclados de computador, envolve intelectuais firmemente entrincheirados nas universidades e redações, prontos para a luta de idéias sobre o significado dos atentados terroristas e qual a atitude correta a ser adotada diante de um eventual conflito. Longe vão os dias em que o front intelectual formava praticamente unânime na militância pacifista, no caso da Guerra do Vietnã. As fronteiras tradicionais entre direita e esquerda também ruíram, pelo menos em parte, tragadas pela enormidade do horror que se abateu sobre Nova York e Washington. A batalha das palavras envolve, mais apropriadamente, dois lados: os rápidos e os lentos. Os rápidos são aqueles que captaram as dimensões da mudança provocada pelos ataques. Perceberam que noções perfeitamente aceitáveis do mundo

\footnotetext{
71 "polemistas - movidos pelo zelo e hostilidade com tudo relacionado aos muçulmanos"

72 "em despertar sentimentos de alame e consternação em seus leitores"
} 
pré-atentados não se aplicavam mais depois deles. Os lentos, tanto conservadores quanto liberais, não assimilaram a guinada e continuaram a rodar o mesmo programa mental que tinham antes.

O mais vistoso combatente da turma dos rápidos é Christopher Hitchens, jornalista inglês radicado nos Estados Unidos, tão provocador que escreveu um livro no qual Madre Teresa de Calcutá é retratada como uma sádica oportunista que maltratava os pobres doentes entregues a seus cuidados. Hitchens foi para a briga com um artigo no qual metralhou o chamado relativismo moral dos intelectuais para os quais, de maneira bem resumida, "os Estados Unidos estão colhendo o que plantaram”. Nada na política externa americana, argumentou ele, justifica os atentados. Só um “cretino moral”, escreveu, imaginaria que os terroristas desistiriam de seu plano maligno se, por exemplo, os israelenses acabassem com a brutal repressão nos territórios palestinos. "Os Estados Unidos fazem realmente muita coisa errada mundo afora", disse Hitchens a VEJA. "O problema desses intelectuais é que não podem admitir que o governo americano faça alguma coisa certa. É uma espécie de masoquismo. Não os acuso de cumplicidade com os terroristas, mas de estupidez". Os mísseis de Hitchens têm endereço certo: o linguista Noam Chomsky e sua turma. Ícone da esquerda e último refúgio dos preguiçosos (todo mundo bate à sua porta quando quer uma crítica invariável a qualquer iniciativa do governo americano), o veterano professor ficou patentemente do lado dos lentos. Não mudou seu discurso em nada, insistindo em equiparar os atentados suicidas que pulverizaram quase 6.000 pessoas nos Estados Unidos ao bombardeio de uma fábrica de remédios do Sudão, desfechado em 1998 a mando do então presidente Bill Clinton, numa desastrada tentativa de punir colaboradores de Osama bin Laden. Chomsky sustentou, delirantemente, que o bombardeio provocou "milhões" de mortes - depois reduziu para "dezenas de milhares" e disse que eram vítimas da falta de remédios que teriam sido produzidos caso Clinton não tivesse bombardeado a fábrica. Para se ter idéia da discrepância, o ataque americano em si não matou ninguém. Na resposta a Hitchens, Chomsky acusouo de "desprezo racista pelas vítimas africanas" do bombardeio. O jornalista treplicou em tom mais virulento ainda, com tanta sofreguidão que, a certa altura, não acusava mais a esquerda, e sim o governo Bush, de contemporizar demais na repressão aos terroristas! A confusão é natural. O próprio presidente americano e seu grupo de brucutus conservadores alinharam-se entre o pessoal da reação rápida, o que desarticulou seus críticos. Edward Said, o mais conhecido intelectual palestino, 
professor da Universidade Columbia, foi um caso clássico. Escrevendo no piloto automático, afirmou que "o dia 11 de setembro se transformou numa enorme propaganda em beneficio de Sharon", o primeiro-ministro de Israel, duro entre os duros. Errado. Bush falou na semana passada, pela primeira vez, na eventual criação de um Estado palestino, o tipo de assunto que provoca apoplexia em gente como Sharon. Quem achava que a religião muçulmana seria lançada na vala comum do terrorismo (com reações de horror entre a esquerda, de gáudio para os direitistas lentos) ficou sem ter o que falar diante das insistentes loas tecidas pelo presidente caipira à fé dos seguidores do profeta Maomé. Você, caro leitor, está condoído pela sorte dos pobres afegãos que agora engrossam as fileiras dos refugiados? Donald Rumsfeld, o superfalcão do Departamento de Defesa, também ficou de "coração partido", e lá se foram 320 milhões de dólares dos EUA para ajudar os flagelados afegãos.

Tantas manifestações de flexibilidade não bastaram para impressionar gente como a escritora Susan Sontag, que insistiu com todas as letras que o atentado foi uma consequência direta das ações e alianças americanas. Sontag ainda acrescentou que os terroristas não eram covardes - a coragem é uma virtude moralmente neutra, disse, com razão, mas sem nenhum senso de oportunidade. Sontag deve ter esquecido que já defendeu fervorosamente o uso da força imperialista que agora critica. Há três anos, quando o ditador sérvio Slobodan Milosevic ainda reinava em Belgrado, ela clamou pela intervenção americana, defendendo o bombardeio dos sérvios para evitar a matança dos albaneses de Kosovo (muçulmanos salvos pelos Estados Unidos). $O$ embate de idéias, natural nos ambientes intelectuais, caiu mal em alguns círculos mais rudes. Rod Dreher, colunista do jornal New York Post, escreveu que gostaria de atravessar a ponte do Brooklyn, em Nova York, de pés descalços sobre cacos de vidro, até o apartamento de Sontag, agarrá-la pelo pescoço, arrastá-la ao World Trade Center e fazê-la repetir o que havia escrito diante dos bombeiros que trabalharam nos escombros dos prédios.

Os ânimos andam acirrados, a ponto de nas marchas antiglobalização ocorridas há duas semanas em Washington os manifestantes terem sido chamados de traidores da pátria por gente mais exaltada. Num clima assim, veio em boa hora a bem-humorada receita para vencer o fanatismo dada por Salman Rushdie, o escritor anglo-indiano agora radicado em Nova York, ele mesmo vítima do obscurantismo. "Devemos concordar no que importa: beijar em lugares públicos, sanduíches de bacon, 
discordâncias, roupas decotadas, literatura, generosidade, água, uma distribuição mais equânime dos recursos do mundo, filmes, música, liberdade de pensamento, beleza e amor", escreveu. Desde que foi jurado de morte pelos fundamentalistas iranianos, em 1989, Rushdie vive sob proteção policial.

Tabela 12: Reportagem revista Veja edição 1721 - 10 de outubro de 2001.

\begin{tabular}{|c|c|}
\hline Discurso direto & $\begin{array}{l}\text { - Christopher Hitchens, jornalista inglês } \\
\text { - Noam Chomsky, linguista norte- } \\
\text { americano } \\
\text { - Edward Said, intelectual palestino- } \\
\text { americano } \\
\text { - Salman Rushdie, escritor anglo-indiano }\end{array}$ \\
\hline Discurso indireto & $\begin{array}{l}\text { - Christopher Hitchens, jornalista inglês } \\
\text { - Noam Chomsky, linguista norte- } \\
\text { americano } \\
\text { - Susan Sontag, escritora norte-americana } \\
\text { - Rod Dreher, norte-americano, colunista } \\
\text { do The New York Post }\end{array}$ \\
\hline Pressuposições existenciais & $\begin{array}{l}\text { - } a \text { bem-humorada receita para vencer } o \\
\text { fanatismo } \\
\text { - Desde que foi jurado de morte pelos } \\
\text { fundamentalistas iranianos }\end{array}$ \\
\hline $\begin{array}{l}\text { Afirmações avaliativas/presunções } \\
\text { valorativas }\end{array}$ & $\begin{array}{l}\text { - A guerra está sendo dura e suja } \\
\text { - A batalha das palavras envolve, mais } \\
\text { apropriadamente, dois lados: os rápidos e } \\
\underline{\text { os lentos }} \\
\text { - Os rápidos são aqueles que captaram as } \\
\text { dimensões da mudança provocada pelos } \\
\text { ataques }\end{array}$ \\
\hline
\end{tabular}




\begin{tabular}{|l|l|}
\hline & $\begin{array}{l}\text {-Os lentos, tanto conservadores quanto } \\
\text { liberais, não assimilaram a guinada e } \\
\text { continuaram a rodar o mesmo programa } \\
\text { mental que tinham antes }\end{array}$ \\
$\begin{array}{l}\text { - O mais vistoso combatente da turma dos } \\
\text { rápidos é Christopher Hitchens }\end{array}$ \\
\hline $\begin{array}{l}\text { - Ícone da esquerda e último refúgio dos } \\
\text { preguiçosos }\end{array}$ \\
\hline & \\
\hline & \\
\hline
\end{tabular}

Para Veja, o 11 de setembro não tornou ainda mais profunda apenas a divisão entre "nós", os ocidentais, e "eles", os muçulmanos, mas também uma divisão entre intelectuais rápidos e lentos. No maniqueísmo simplificador da revista, aos primeiros cujas posições são idênticas às da publicação - são atribuídas qualidades engrandecedoras. Eles são aqueles que captaram as dimensões da mudança provocada pelos ataques. Perceberam que noções perfeitamente aceitáveis do mundo pré-atentados

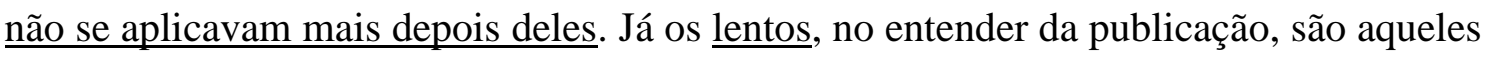
que não assimilaram a guinada e continuaram a rodar o mesmo programa mental que tinham antes. Veja classifica de lentos os que discordam de sua visão de mundo. Segundo Giddens (2002, p. 22), a rapidez é "uma das características mais óbvias que separa a era moderna de qualquer período anterior é seu extremo dinamismo. O mundo moderno é um "mundo em disparada", e na maior parte dos textos analisados neste trabalho os muçulmanos são vistos - através de sintagmas nominais que transformam fundamentalistas em sinônimo de islâmico - como contrários à moderninade ou até mesmo o antônimo de moderno. É o caso da reportagem "O pior lugar do mundo" (texto 2), quando a revista diz que os guerrilheiros e milicianos de Serra Leoa formam uma curiosa caricatura de elementos primitivos; em "De nariz novo" (texto 4), ao dizer que desde que os aiatolás chegaram ao poder no Irã, trataram de atrasar o relógio da História; da "Carta ao leitor" (texto 5), quando a revista diz que o que os radicais não toleram, mais que tudo, é a modernidade; em "Ou estão do nosso lado ou do lado dos terroristas" (texto 7), ao caracterizá-los como um bando de guerreiros montados em 
cavalos e camelos; ao dizer, em "Este país já está arrasado" (texto 8), que o Afeganistão vive um atraso endêmico e tem uma economia primitiva; e em "O vírus anti-EUA" (texto 9), ao dizer que a democracia e a modernidade a que se expõem os islâmicos no contato com os Estados Unidos são venenos para as elites locais. Ou seja, "nós" somos os rápidos, enquanto "eles", e todos que contrariam o discurso hegemônico norteamericano, são os lentos. A isso, Veja adiciona contornos belicistas. Há, na visão da publicação, não apenas uma discordância de opiniões entre os intelectuais firmemente

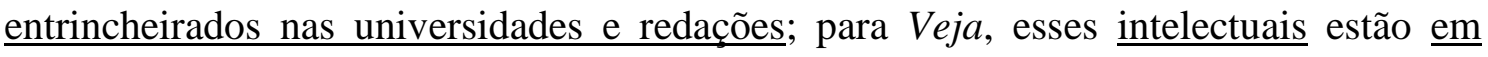
guerra, em uma batalha das palavras. Ainda em linguajar militaresco, é possível dizer que para construir sua estrutura discursiva Veja contou com fortes aliados, utilizando ideias contidas em textos de duas publicações estrangeiras. Como já apresentado neste trabalho, a revista apresentou trechos de unidades textuais que se assemelham a textos do The New York Times em "De nariz novo" e "O vírus anti-EUA". No caso de "Intelectuais em guerra" (texto 12), é possível identificar semelhanças em reportagens publicadas pelo diário norte-americano e também pela revista inglesa The Economist. Desta vez, ainda em seu primeiro parágrafo, publicado em 10 de outubro de 2001, a reportagem de Veja diz que longe vão os dias em que o front intelectual formava praticamente unânime na militância pacifista, no caso da Guerra do Vietnã. As fronteiras tradicionais entre direita e esquerda também ruíram, pelo menos em parte, tragadas pela enormidade do horror que se abateu sobre Nova York e Washington. O texto "Treason of the intellectuals" ${ }^{73}$, da revista The Economist, publicado seis dias antes, em 4 de outubro de 2001, diz em seu primeiro parágrafo: $B A C K$ in Vietnam days, the anti-war movement spread from the intelligentsia into the rest of the population, eventually paralysing the country's will to fight. At first sight, the danger of the same thing happening now looks slim. The overwhelming majority of Americans are solidly behind George Bush. Yet the drumbeat of opposition, already fairly deafening in parts of the European left, is building up in America. Assim como quando Veja diz que $\underline{\mathbf{o}}$ mais vistoso combatente da turma dos rápidos é Christopher Hitchens, jornalista inglês radicado nos Estados Unidos e que os mísseis de Hitchens têm endereço certo: o linguista Noam Chomsky e sua turma. Ícone da esquerda e último refúgio dos preguiçosos (todo mundo bate à sua porta quando quer uma crítica invariável a qualquer iniciativa do governo americano), o veterano professor ficou patentemente do lado dos

\footnotetext{
${ }^{73}$ Disponível em: <http://www.economist.com/node/806289>.
} 
lentos, o texto "Counterpoint to unity: distent" 74 , do The New York Times, publicado quatro dias antes, em 6 de outubro de 2001, dizia: another figure from the antiwar $\underline{\text { movement is Mr. Chomsky [...] He has long since stopped getting much notice among }}$ mainstream journals of opinion in the United States, but he retains an avid following among the numerous small leftist groups with magazines and Web sites and among the foes of so-called globalization, e completava dizendo que: his most visible critic from the left was the writer Christopher Hitchens, whose columns over the years in The Nation have not generally shown him to be an uncritical admirer of the American role in the world. Veja utilizou os mesmos exemplos apresentados pelo diário norteamericano, apenas invertendo a ordem. Assim como escolheu utilizar exatamente o mesmo argumento de Chomsky destacado pelo The New York Times para desqualificar as críticas do linguista. O The New York Times publicou que "the terrorist attacks were major atrocities." Mr. Chomsky wrote, "but in scale they may not reach the level of many others, for example, Clinton's bombing of the Sudan with no credible pretext, destroying half its pharmaceutical supplies and killing unknown numbers of people." His reference was to the 1998 missile attack against a factory that was believed by American intelligence to be a cover for a chemical weapons plant. Veja disse que Chomsky não mudou seu discurso em nada, insistindo em equiparar os atentados suicidas que pulverizaram quase 6.000 pessoas nos Estados Unidos ao bombardeio de uma fábrica de remédios do Sudão, desfechado em 1998 a mando do então presidente Bill Clinton, numa desastrada tentativa de punir colaboradores de Osama bin Laden. Chomsky sustentou, delirantemente, que o bombardeio provocou "milhões" de mortes. Veja garante, ainda que não diga onde, que Edward Said, classificado como o mais conhecido intelectual palestino, teria afirmado que "o dia 11 de setembro se transformou numa enorme propaganda em benefício de Sharon”. A revista se apressou em classificar o raciocínio como errado, pois, segundo ela, o presidente George Bush falou, pela primeira vez, na eventual criação de um Estado palestino. Veja, no entanto, não publicou um só argumento de Said publicado por jornais estrangeiros, como The Guardian, no dia 16 de setembro, e The Nation, em 4 de outubro, ainda que em seu artigo para o Guardian ${ }^{75}$ Said tenha tratado da questão central do texto de Veja.

\footnotetext{
${ }^{74}$ Disponível em: <http://www.nytimes.com/2001/10/06/arts/counterpoint-to-unitydissent.html?scp=2\&sq=chomsky\&st=nyt\&pagewanted=all $>$.

${ }^{75}$ Disponível em: <http://www.guardian.co.uk/world/2001/sep/16/september11.terrorism3>.
} 


\section{4 - Análise corpus pós-11 de setembro}

Texto 13: Reportagem revista Veja edição 1768 - 11 de setembo de 2002.

\section{POR QUE O ISLÃ NÃO SENTE REMORSO}

Os dezenove terroristas responsáveis pela carnificina no World Trade Center e no Pentágono eram árabes e muçulmanos. Eles atacaram em nome de uma versão fundamentalista do Islã minoritária entre o 1,3 bilhão de muçulmanos. Um ano depois do atentado, a reação da maioria islâmica ao desafio da minoria fanática ainda é uma questão sem resposta

Um efeito notável dos atentados de 11 de setembro foi o de revelar para a maioria das pessoas a existência de um mundo obscuro, agressivamente primitivo e vingativo, o do fundamentalismo islâmico. Tão logo se soube que a carnificina fora cometida em nome de Alá, levantou-se um coro de vozes sensatas - entre elas a do presidente americano George W. Bush - para garantir que Osama bin Laden e os dezenove sequestradores não podiam ser vistos como a verdadeira face do islamismo, religião com 1.400 anos de existência e 1,3 bilhão de fiéis. Um ano depois, ainda está em aberto a questão de como o mundo muçulmano reagirá ao desafio da minoria fanática e sedenta de sangue. O que se viu até agora é pouco animador. Do Marrocos à Indonésia, as ruas foram tomadas por manifestações a favor de Osama bin Laden. No Paquistão, os mulás emitiram decretos religiosos, as chamadas fatwas, convocando os fiéis à guerra santa contra os americanos no Afeganistão, e milhares de voluntários atenderam ao chamado.

O historiador americano Daniel Pipes estimou, em entrevista a VEJA, que a versão extremista atrai a simpatia de menos de $15 \%$ dos muçulmanos. Isso torna mais intrigante a escassez de oposição pública ao terrorismo no universo desses países. No início dos anos 90, Samuel Huntington, da Universidade Harvard, defendeu a tese de que, encerrada a disputa ideológica entre capitalismo e comunismo, o confronto global 
mais iminente seria o choque de civilizações entre o Ocidente e o Islã. Na prática, as coisas são um pouco mais complexas, pois o mundo islâmico é muito diversificado. $O$ historiador americano-palestino Edward Said acredita que, na realidade, os atentados são consequência de uma disputa por corações e almas entre diferentes correntes islâmicas no mundo árabe. Essa disputa se alimenta do fracasso político, cultural e econômico acumulado pelos países muçulmanos após o fim do colonialismo europeu. $O$ sentimento de frustração desses povos é intensificado por uma infecção cultural típica do Oriente Médio: a arraigada convicção de que todos os acontecimentos significativos têm origem numa conspiração externa.

O mundo moderno é repleto de promessas - mas a maioria dos muçulmanos é pobre demais para usufruir delas. Muito mais presente é a desorientação cultural produzida pela própria modernidade. Os regimes árabes são, praticamente todos, arremedos ditatoriais de modelos políticos ocidentais, com pouco a oferecer a seus cidadãos. Os fundamentalistas, em contrapartida, prometem um mundo de regras bem definidas, com destaque para a guerra maniqueístca entre os crentes e os infiéis. Francis Fukuyama, professor de política econômica internacional da Universidade John Hopkins, diz que os americanos tendem a acreditar que seus valores e instituições - democracia, direitos individuais e liberdade econômica - são aspirações universais. Infelizmente não é assim. Enquanto a maioria dos povos da América Latina, da Ásia e da África inveja a riqueza das nações desenvolvidas, os fanáticos fundamentalistas só vêem provas de consumismo decadente no mundo ocidental. As massas do mundo árabe tenderam a comemorar os atentados de 11 de setembro porque essa tragédia, segundo a visão de muitos que aprovaram o ataque, humilhou os Estados Unidos, país que eles consideram corrompido e infiel. "A corrupção não se expressa na permissividade ou nos direitos da mulher, mas na sociedade leiga. O que detestam é que o Estado promova o pluralismo religioso e tolerância, em vez de ser um servo da verdade religiosa”, diz Fukuyama. A ofensiva militar contra a Al Qaeda é uma boa forma de neutralizar o terrorismo islâmico. Mas haverá sempre um problema de grande envergadura se os próprios países islâmicos não derem sua contribuição no combate ao terrorismo. O desafio para a comunidade muçulmana está na convivência com o princípio do estado leigo e da tolerância religiosa. "Ela precisa decidir se quer fazer as pazes com a modernidade", afirma Fukuyama. 
Tabela 13: Reportagem revista Veja edição 1768 - 11 de setembo de 2002.

\begin{tabular}{|c|c|}
\hline Discurso direto & - Francis Fukuyama \\
\hline Discurso indireto & $\begin{array}{l}\text { - George W. Bush } \\
\text { - Daniel Pipes, historiador norte- } \\
\text { americano } \\
\text { - Samuel Huntington, norte-americano, } \\
\text { professor da Universidade de Harvard } \\
\text { - Edward Said, historiador americano- } \\
\text { palestino } \\
\text { - Francis Fukuyama, norte-americano, } \\
\text { professor da Universidade John Hopkins }\end{array}$ \\
\hline Pressuposições existenciais & $\begin{array}{l}\text { - uma versão fundamentalista do Islã } \\
\text { - da maioria islâmica } \\
\text { - da minoria fanática } \\
\text { - } a \text { existência de um mundo obscuro, } \\
\text { agressivamente primitivo e vingativo } \\
\text { - do fundamentalismo islâmico } \\
\text { - o mundo muçulmano reagirá } \\
\text { - da minoria fanática e sedenta de sangue } \\
\text { - do fracasso político, cultural e } \\
\text { econômico acumulado pelos países } \\
\text { muçulmanos } \\
\text { - uma infecção cultural típica do Oriente } \\
\text { Médio } \\
\text { - } a \text { arraigada convicção de que todos os } \\
\text { acontecimentos significativos têm origem } \\
\text { numa conspiração externa } \\
\text { - } a \text { desorientação cultural produzida pela }\end{array}$ \\
\hline
\end{tabular}




\begin{tabular}{|c|c|}
\hline & $\begin{array}{l}\text { própria modernidade } \\
\text { - os fundamentalistas } \\
\text { - os fanáticos fundamentalistas } \\
\text { - o terrorismo islâmico } \\
\text { - a maioria dos povos da América Latina, } \\
\text { da Ásia e da África inveja a riqueza das } \\
\text { nações desenvolvidas }\end{array}$ \\
\hline $\begin{array}{l}\text { Afirmações avaliativas/presunções } \\
\text { valorativas }\end{array}$ & $\begin{array}{l}\text { - Por que o Islã não sente remorso } \\
\text { - um mundo obscuro, agressivamente } \\
\text { primitivo e vingativo, o do } \\
\text { fundamentalismo islâmico } \\
\text { - a carnificina fora cometida em nome de } \\
\underline{\text { Alá }} \\
\text { - o que se viu até agora é pouco animador } \\
\text { - a maioria dos muçulmanos é pobre } \\
\underline{\text { demais }} \\
\text { - Os regimes árabes são, praticamente } \\
\underline{\text { todos, arremedos ditatoriais de modelos }} \\
\text { políticos ocidentais } \\
\text { - a maioria dos povos da América Latina, } \\
\text { da Ásia e da África inveja a riqueza das } \\
\text { nações desenvolvidas } \\
\text { - A ofensiva militar contra a Al Qaeda é } \\
\text { uma boa forma }\end{array}$ \\
\hline
\end{tabular}

Na unidade textual é possível verificar uma tentativa da revista de realizar uma distinção entre dois "Islãs" - um minoritário, radical e fundamentalista; outro, majoritário e moderado. O maniqueísmo conduz a generalizações e não perde de vista a desconfiança contra o "outro". A generalização se evidencia logo no título da reportagem, quando a revista afirma que o Islã não sente remorso. A presença da conjunção Por que do título, sendo ela a soma da preposição por mais o pronome que, é 
sinônimo de por qual razão, por qual motivo. O título, então, sugere que a revista irá explicar o porquê de o Islã não sentir remorso. A desconfiança surge logo na sequência, ainda no subtítulo, quando a revista diz que ainda é uma questão sem resposta a reação da maioria islâmica ao desafio da minoria fanática, e é reforçada no primeiro parágrafo, mesmo depois de Veja classificar de sensatas as vozes que se levantaram para garantir que Osama bin Laden e os dezenove sequestradores não podiam ser vistos como a verdadeira face do islamismo: o que era uma questão sem resposta passa a algo pouco animador.

É importante notar que Veja cita cinco vozes em seu texto. Além do presidente George W. Bush, os discursos de quatro especialistas são utilizados explicitamente na unidade textual. Três deles foram previamente discutidos neste trabalho e têm posições bastante claras no contexto da relação Ocidente-Oriente. Samuel Huntington e Francis Fukuyama, notamente críticos dos países árabes e de maioria muçulmana, e Edward Said, um crítico da maneira como Huntington e Fukuyama enxergam os países do Oriente Médio. O quarto especialista é o historiador americano Daniel Pipes, que em entrevista a Veja estimou que a versão extremista atrai a simpatia de menos de $15 \%$ dos $\underline{\text { muçulmanos. A partir dessa estimativa a publicação afirma que há uma escassez de }}$ oposição pública ao terrorismo no universo desses países. A revista não demonstrou curiosidade ou interesse em entender como Pipes chegou a esses números. Também não fez qualquer ressalva ao polêmico perfil do entrevistado de notório gosto por frases polêmicas, como "I have the simple politics of a truck driver, not the complex ones of an academic. My viewpoint is not congenial with institutions of higher learning" ${ }^{76}$. As posições do historiador de origem judaica, filho do também historiador Richard Pipes, eram já à época bastante conhecidas. Alguns meses depois das declarações a Veja, o presidente George W. Bush o indicou para a direção do U.S. Institute of Peace, think tank financiado pelo governo norte-americano, o que levou o senador democrata Edward M. Kennedy a dizer que o histórico de Pipes "did not reflect a commitment to bridging differences and preventing conflicts" 77 , e seu colega de Partido Democrata Tom Harkin a afirmar que "the controversy could 'overshadow' the institute's work" 78. As declarações foram registradas pelo jornal The Washington Post na reportagem

\footnotetext{
76 "Eu tenho as simples opiniões políticas de um motorista de caminhão, não as complexas de um acadêmico. Meu ponto de vista não é adequado com as instituições de alta erudição.” Disponível em: <http://harvardmagazine.com/2005/01/militant-about-islamism.html\#>.

77 "não refletia um compromisso para construção de pontes entre as diferenças e prevenção de conflitos"

78 "a controvérsia poderia ofuscar o trabalho do instituto"
} 
"Pipes to Be Named to Think Tank; Controversial Mideast Scholar Will Be Recess Appointment ${ }^{79}$, que informa ainda que "Muslim organizations and some Jewish groups have campaigned vigorously since April against Pipes's nomination" ${ }^{80}$ e que o Council on American-Islamic Relations declarou que Pipe é "known for his hostility to Muslims" ${ }^{81}$. Atualmente, Pipes é conhecido por ter acusado o presidente norteamericano Barack Obama de ter mentido sobre sua infância para esconder suas origens muçulmanas. As acusações foram divulgadas em pelo menos duas publicações, o jornal israelense The Jerusalem Post ${ }^{82}$ e a norte-americana FrontPage Magazine ${ }^{83}$, conhecida por eleger como personalidades do ano figuras públicas como a jornalista italiana Oriana Fallaci, notória, segundo reportagem do New York Times ${ }^{84}$, por criticar "not only Islamic extremists but also Islam itself" 85 com declarações como "the sons of Allah breed like rats" ${ }^{86}$. Segundo Viviane Ramalho (2005, p. 93-94), "dado que práticas sociais encerram diferentes discursos e interesses particulares, a presença de uma voz específica [...] em vez de outras, sinaliza o posicionamento do texto nas lutas de poder. Dos quatro especialistas citados por Veja, além do presidente George W. Bush, apenas as palavras de Fukuyama foram citadas entre aspas. Fairclough (2003, p. 61), como já mecionado neste trabalho, estabelece uma escala de dialogicidade nos textos, "in which the most dialogical option is the inclusion of other voices and the attribution to them of quotations". No entanto, como vemos na reportagem de Veja, a inclusão de outras vozes por si só não garante posição de grande dialogicidade, especialmente quando são utilizadas quatro posições compartilhadas e apenas uma destoante. O discurso indireto pode levar a situações duvidosas. É o exemplo da declaração de Said, quando Veja diz: $\underline{\text { O historiador americano-palestino Edward Said }}$ acredita que, na realidade, os atentados são consequência de uma disputa por corações e

\footnotetext{
${ }^{79}$ Disponível em:

<http://pqasb.pqarchiver.com/washingtonpost/offers.html?url=\%2Fwashingtonpost\%2Faccess\%2F38718 2371.html\%3FFMT\%3DFT\%26FMTS\%3DABS\%3AFT\%26date\%3DAug\%2B22\%252C\%2B2003\%26a uthor\%3DAlan\%2BCooperman\%26pub\%3DThe\%2BWashington\%2BPost \%26startpage\%3DA.04\%26d esc\%3DPipes\%2Bto\%2BBe\%2BNamed\%2Bto\%2BThink\%2BTank\%253B\%2BControversial\%2BMidea st\%2BScholar\%2BWill\%2BBe\%2BRecess\%2BAppointment $>$.

80 “Organizações muçulmanas e alguns grupos judeus têm desde abril vigorosamente feito campanha contra a nomeação de Pipes”

81 "conhecido por sua hostilidade contra os muçulmanos"

${ }^{82}$ Disponível em:

<http://fr.jpost.com/servlet/Satellite?cid=1219572122800\&pagename=JPost/JPArticle/ShowFull>.

${ }^{83}$ Disponível em: <http://archive.frontpagemag.com/readArticle.aspx?ARTID=29425\#>.

${ }^{84}$ Disponível em:

<http://www.nytimes.com/2006/09/16/books/16fallaci.html?_r=1\&scp=1\&sq=Oriana\%20Fallaci\%20obit uary $\&$ st $=$ cse $>$.

85 "não apenas extremistas islâmicos, mas também o Islã em si mesmo"

86 “os filhos de Alá se reproduzem como ratos"
} 
almas entre diferentes correntes islâmicas no mundo árabe. Essa disputa se alimenta do fracasso político, cultural e econômico acumulado pelos países muçulmanos após o fim do colonialismo europeu. O sentimento de frustração desses povos é intensificado por uma infecção cultural típica do Oriente Médio: a arraigada convicção de que todos os acontecimentos significativos têm origem numa conspiração externa. É legítimo e necessário que se pergunte até onde vai o pensamento de Said e onde começa a assunção de Veja. Teria sido Said ou a própria revista a dizer que os países muçulmanos acumulam um fracasso cultural? Tal ponto nos leva novamente a Fairclough, quando ele diz que:

\begin{abstract}
Both intertextuality and assumption can be seen in terms of claims on the part of the "author" - the claim that what is reported was actually said, that what is assumed has indeed been said or written elsewhere, that one's interlocutors have indeed heard it or read it elsewhere. Such claims may or may not be substantiated. People may mistakenly, or dishonestly, or manipulatively make such implicit claims - assertions may for instance be manipulatively passed off as assumptions, statements may mistakenly or dishonestly be attributed to others. (FAIRCLOUGH, 2003, p. 40). ${ }^{87}$
\end{abstract}

Na escala de dialogicidade de Fairclough (2001, p. 61), "the least dialogical option is assumption, taking things as given" ${ }^{88}$. Em "Por que o Islã não sente remorso" podem ser encontradas pelo menos quinze pressuposições, como mostra a Tabela $1 \mathrm{C}$.

Pressuposições são proposições que são tomadas pelo(a) produtor(a) do texto como já estabelecidas ou "dadas" [...] os artigos definidos indicam proposições que têm significados "existenciais" (por exemplo, "a ameaça soviética” pressupõe que há uma ameaça soviética). (FAIRCLOUGH, 2001, p. 155).

Segundo Fairclough, implicitude é uma propriedade bastante arraigada em textos. Todo tipo de interação social depende de significados compartilhados e não pode existir sem algum senso comum. Mas ele não surge ao acaso. A capacidade de exercer poder social, dominação e hegemonia inclui a capacidade de modelar em algum nível de significação o senso comum, "which makes implicitness and assumptions an important issue with respect to ideology" ${ }^{89}$, (FAIRCLOUGH, 2001, p. 55), e leva a questões relativas à

\footnotetext{
87 'Intertextualidade e pressuposições podem ser vistas em termos de afirmações da parte do 'autor' - a afirmação de que o que está reportado foi de fato dito, que o que foi assumido foi na verdade dito em outro lugar, que um interlocutor realmente leu ou ouviu isso em outro lugar. Tais afirmações podem ou não ser confirmadas. Pessoas podem erroneamente, desonestamente ou manipulativamente fazer afirmações implícitas - afirmações podem, por exemplo, manipulativamente passar como assunções, declarações podem erroneamente ou desonestamente ser atribuídas a outros."

88 "na qual a opção mais dialógica é a inclusão de outras vozes e atribuir a elas citações entre aspas [...] e a opção menos dialógica é a assunção, tomando as questões como fatos dados"

89 "que faz implicitude e pressuposição uma importante questão relativa à ideologia"
} 
hegemonia, ou "how particular identities, interests, representations come under certain conditions to be claimed as universal" 90 (2001, p. 40-41).

Texto 14: Reportagem revista Veja edição 1769 - 18 de setembo de 2002.

\section{BUSH DÁ ULTIMATO A SADDAM}

Presidente dos Estados Unidos tenta convencer a ONU a apoiar a derrubada do ditador

O discurso de George W. Bush no dia 11 de setembro, aniversário do ataque terrorista ao World Trade Center, era esperado com a expectativa adequada aos momentos solenes. Mas nada comparável à ansiedade global em torno de seu pronunciamento marcado para a abertura da Assembléia-Geral da Organização das Nações Unidas $(O N U)$, no dia seguinte. O que se queria era que ele dissesse, de uma vez por todas, se ordenará um ataque para depor Saddam Hussein, o ditador do Iraque. E se faria isso sem levar em conta a oposição dos países aliados. O discurso da quinta-feira passada serviu para esclarecer um ponto fundamental: os Estados Unidos estão dispostos a invadir o Iraque sozinhos, mas preferem agir com os aliados e com o respaldo das Nações Unidas. Bush pediu à ONU que atue para forçar Saddam a obedecer às resoluções da própria ONU. "Nós trabalharemos com o Conselho de Segurança pelas resoluções necessárias, mas os propósitos dos Estados Unidos não devem ficar em dúvida”, disse o presidente. “A ação será inevitável pela segurança e pela paz." $O$ ultimato a Saddam inclui um desafio à ONU. Com sua posição, Bush pretende que a organização faça as exigências necessárias ao ditador para ver se ele as cumpre. Nas contas americanas, foram dezesseis resoluções desde 1990, nenhuma delas inteiramente respeitadas por Bagdá. No caso de Saddam não cumprir as exigências, Bush teria o pretexto para convocar uma coalizão contra o Iraque, ou agir por conta própria.

O desejo manifestado pelo presidente americano de trabalhar com as Nações Unidas para conter o Iraque não é suficiente

\footnotetext{
90 “como identidades, interesses e representações particulares vêm, sob certas condições, a ser reclamadas como universais"
} 
para acalmar os outros países, temerosos dos efeitos globais de uma nova guerra no Oriente Médio. A ansiedade dos aliados europeus e asiáticos só aumentou com a ameaça implícita de que os Estados Unidos estão dispostos a tomar o assunto em suas próprias mãos se o Iraque ignorar novamente a organização. De todas as resoluções do Conselho de Segurança, a mais importante é a que diz respeito à supervisão internacional da destruição do arsenal nuclear, químico e bacteriológico - as chamadas armas de destruição em massa - que o Iraque já tenha ou esteja tentando produzir. Em 1998, cansados de ser ludibriados pelos iraquianos, os inspetores da ONU abandonaram o país. Nunca mais puderam voltar. Os EUA julgam, com boas razões, que Saddam não aceita as inspeções por ter muito a esconder. Na semana passada, um relatório preparado pelo Instituto Internacional de Estudos Estratégicos, de Londres, estimou que os iraquianos podem montar armas nucleares em poucos meses se conseguirem comprar no exterior material radiativo necessário para a bomba. Por sorte, eles não têm condições, por enquanto, de produzi-lo por conta própria.

De modo geral, a União Européia concorda com a necessidade de policiar as ações de Saddam, um ditador sanguinário que já invadiu dois países vizinhos e usou gases venenosos contra o próprio povo. Mas prefere fazer isso por meio de pressão diplomática e sanções econômicas. A divergência com os Estados Unidos decorre do fato de que Bush não deseja apenas neutralizar os arsenais iraquianos, mas, principalmente, derrubar do poder o ditador de Bagdá. O segundo objetivo parece até mais relevante que o primeiro, como se o presidente quisesse terminar o trabalho iniciado por seu pai. Em 1991, depois de expulsar as tropas iraquianas que haviam invadido o Kuwait, Bush pai decidiu não perseguir os derrotados até Bagdá. O trabalho inacabado ainda está atravessado na garganta dos Bush. Com seu discurso na $O N U$, o presidente americano tentou conseguir respaldo internacional para um ataque tremendamente impopular entre seus amigos. Nem o apoio do primeiro-ministro inglês, Tony Blair, o mais fiel aliado de Washington, poderia ser assegurado no caso de um ataque unilateral. De certa forma, Washington está seguindo o conselho de Jacques Chirac, presidente da França e crítico severo da idéia americana de depor Saddam. Numa entrevista ao New York Times, às vésperas do 11 de setembro, Chirac sugeriu aos americanos que pedissem primeiro à ONU que adotasse medidas contra Saddam. Se ele se negar a colaborar, seria mais fácil para Washington obter, se não o apoio com tropas, pelo menos certa neutralidade crítica das outras potências, incluindo a China e a Rússia. A reação internacional ao discurso na ONU foi mais calorosa do que 
se poderia esperar, visto que só Israel, por motivos óbvios, apóia publicamente os planos americanos de depor Saddam. O espanhol José María Aznar até se apressou a dizer que apoiaria a ação militar americana. O fato de Bush tentar atrair a ONU para sua campanha contra o Iraque não torna a situação menos volátil. O que deixa o mundo em suspenso são as incertezas da deposição de Saddam. Na sexta-feira passada, a simples notícia de que o Iraque havia rejeitado a volta dos inspetores fez o preço do petróleo fechar acima dos 28 dólares por barril, um salto de quase $3 \%$ em relação ao dia anterior. Imagine o cenário de pesadelo: acuado pelos Estados Unidos, Saddam poderia invadir a Arábia Saudita ou bombardear os campos petrolíferos do Kuwait. Nessa hipótese, o preço do barril poderia facilmente ultrapassar os 100 dólares e provocar um aprofundamento da recessão mundial. Saddam também poderia lançar mísseis contra Israel. Se o primeiro-ministro Ariel Sharon revidasse, o que é muito provável, visto o seu pavio curto, ficaria difícil manter o mundo árabe fora do conflito. Mesmo que os lençóis de petróleo do Golfo sobrevivessem intactos, o fim do regime de Saddam Hussein poderia criar um perigoso vácuo de poder. Etnias rivais poderiam engalfinhar-se em uma guerra civil - como já ocorreu no passado -, com repercussões desastrosas nos países vizinhos, que compartilham as mesmas minorias. Irã e Turquia poderiam ser obrigados a intervir, arrastados por rebeliões curdas e xiitas, o que aumentaria o conflito. Reconstruir um país como o Iraque é uma tarefa ainda mais acidentada e difícil do que pôr ordem no Afeganistão. É outro bom motivo para só atacar com algum tipo de respaldo da ONU. Dessa forma, a comunidade internacional poderia ser chamada a ajudar na reconstrução. Ao contrário da guerra contra o terrorismo, que teve adesão instantânea de seus aliados depois do 11 de setembro, a guerra para derrubar Saddam abriria um precedente internacional, já que os EUA ainda não têm como provar que atacaram em defesa própria. Na verdade, a razão da urgência em depor o ditador não está clara para ninguém fora do círculo íntimo da Casa Branca. Supõe-se que uma das razões estratégicas seria a de impor uma nova ordem no planeta, menos dependente dos caprichos de déspotas regionais. A queda de Saddam daria um recado aos outros ditadores e líderes extremistas do Oriente Médio. Síria e Líbia abririam os olhos, e o Irã dos aiatolás xiitas seria pressionado por um governo pró-Ocidente no vizinho Iraque. "Mesmo com tanta supremacia militar, os americanos precisam de aliados, de bases militares em outros países, de serviços de inteligência estrangeiros", disse a VEJA o professor de relações internacionais da Universidade de São Paulo José Augusto Guilhon de Albuquerque. Bush enfrenta 
oposição até dos países árabes que são aliados tradicionais, de vários sócios na Otan e também tem um dilema: se recuar, pode dar um trunfo a ser capitalizado por Saddam. Se atacar sem respaldo e com oposição no mundo árabe, pode sofrer reveses difíceis de calcular neste momento. Ele já perdeu o fator-surpresa, que é importante para qualquer investida militar. O que ninguém perde de vista é o petróleo. O Iraque tem a segunda maior reserva de petróleo do mundo, depois da Arábia Saudita. Os Estados Unidos são os maiores consumidores mundiais e precisam importar mais da metade do que consomem. Europa e Japão são completamente dependentes do petróleo do Golfo Pérsico. Essa é uma das razões que levam os americanos a tratar com tanta cordialidade a monarquia corrupta e feudal da Arábia Saudita. Talvez aí esteja outra razão para depor Saddam. O poder de barganha saudita seria bastante reduzido se o petróleo iraquiano pudesse chegar à vontade ao mercado mundial. Hoje, por causa do embargo ao Iraque, que só pode vender uma pequena parte do petróleo que produz, a Arábia Saudita tem mais controle do comércio mundial de óleo.

Tabela 14: Reportagem revista Veja edição 1769 - 18 de setembro de 2002.

\begin{tabular}{|l|l|}
\hline Discurso direto & $\begin{array}{l}\text { - George W. Bush, presidente norte- } \\
\text { americano } \\
\text { - José Augusto Guilhon de Albuquerque, } \\
\text { professor de relações internacionais da } \\
\text { Universidade de São Paulo }\end{array}$ \\
\hline Discurso indireto & $\begin{array}{l}\text { - George W. Bush, presidente norte- } \\
\text { americano }\end{array}$ \\
& $\begin{array}{l}\text { Jacques Chirac, presidente francês } \\
- \text { José María Aznar, presidente espanhol } \\
\text { - Instituto Internacional de Estudos } \\
\text { Estratégicos }\end{array}$ \\
\hline Pressuposições existenciais & $\begin{array}{l}\text { - } a \text { ansiedade global em torno de seu } \\
\text { pronunciamento }\end{array}$ \\
\hline
\end{tabular}




\begin{tabular}{|c|c|}
\hline & $\begin{array}{l}\text { - } a \text { divergência com os Estados Unidos } \\
\text { - ao ditador } \\
\text { - do arsenal nuclear, químico e } \\
\text { bacteriológico - as chamadas armas de } \\
\text { destruição em massa - que o Iraque já } \\
\text { tenha ou esteja tentando produzir }\end{array}$ \\
\hline $\begin{array}{l}\text { Afirmações avaliativas/presunções } \\
\text { valorativas }\end{array}$ & $\begin{array}{l}\text { - Bush pretende que a organização faça as } \\
\text { exigências necessárias ao ditador } \\
\text { - cansados de ser ludibriados pelos } \\
\underline{\text { iraquianos, os inspetores da ONU }} \\
\text { abandonaram o país } \\
\text { - se o Iraque ignorar novamente a } \\
\text { organização } \\
\text { - Os EUA julgam, com boas razões, que } \\
\text { Saddam não aceita as inspeções por ter } \\
\text { muito a esconder } \\
\text { - Saddam, um ditador sanguinário que já } \\
\text { invadiu dois países vizinhos } \\
\text { - A reação internacional ao discurso na } \\
\text { ONU foi mais calorosa do que se poderia } \\
\text { esperar } \\
\text { - Se o primeiro-ministro Ariel Sharon } \\
\underline{\text { revidasse, o que é muito provável, visto o }} \\
\text { seu pavio curto } \\
\text { - ficaria difícil manter o mundo árabe fora } \\
\underline{\text { do conflito }} \\
\text { - Reconstruir um país como o Iraque é } \\
\text { uma tarefa ainda mais acidentada e difícil } \\
\text { do que pôr ordem no Afeganistão } \\
\text { - a guerra para derrubar Saddam } \\
\text { atacaram em defesa própria } \\
\text { os EUA ainda não têm como provar que } \\
\text { and }\end{array}$ \\
\hline
\end{tabular}




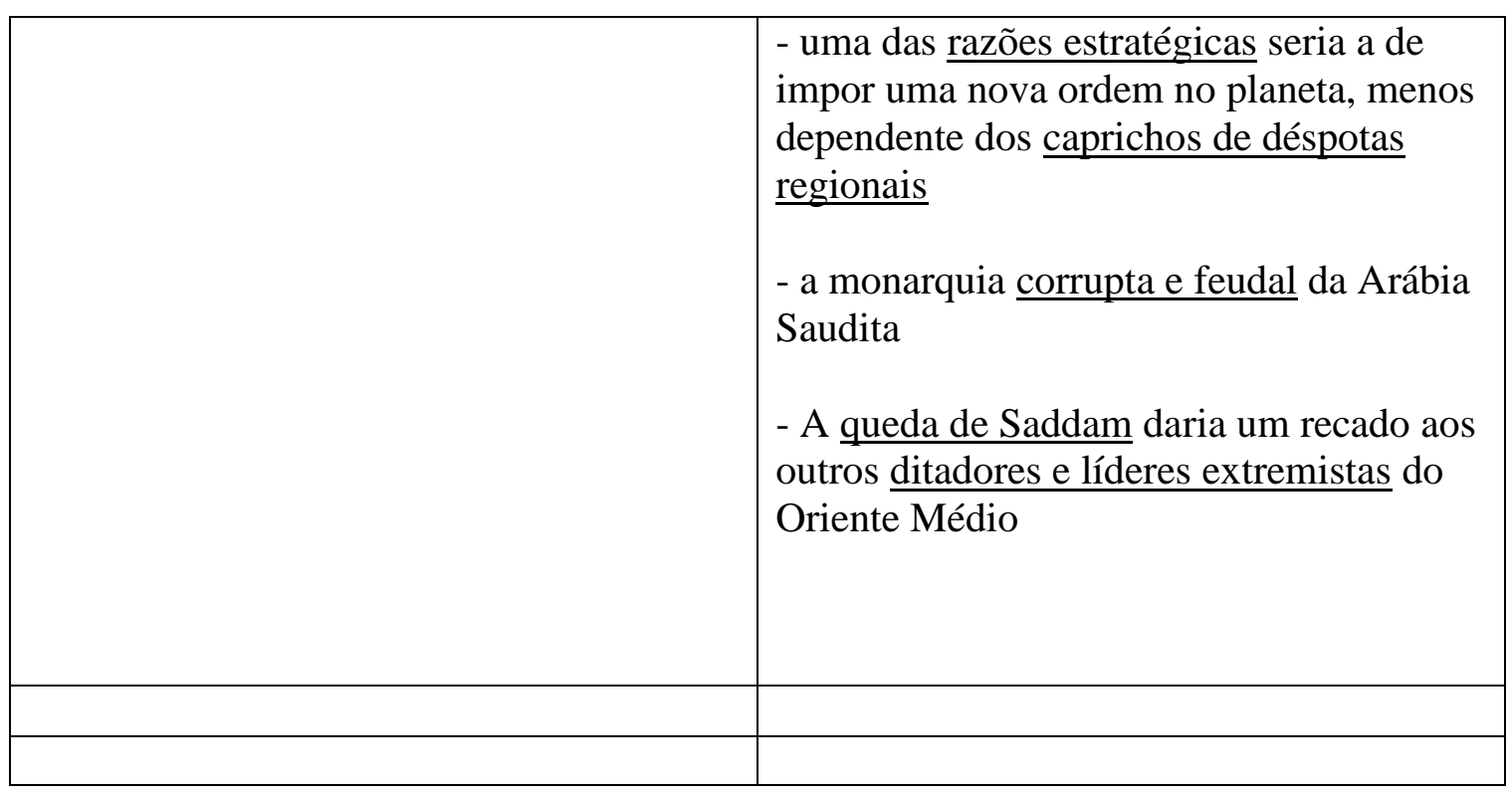

A análise da reportagem "Bush dá ultimato a Saddam" nos mostra a importância de tabulação dos dados que são contabilizados nas unidades textuais verificadas. $\mathrm{O}$ levantamento quantitativo permite perceber ser falsa a avaliação que poderia ser feita sem utilização dos dados. Nesse caso, o uso de discurso direto do presidente George W. Bush, ainda no primeiro parágrafo, pode levar à crença de que, diferentemente das unidades textuais anteriormente analisadas, Veja não assumiu como suas as posições do governo norte-americano. Tal crença inicial é reforçada por construções sintáticas como nas contas americanas, quando a publicação não toma como fato dado - mas sim atribui diretamente aos Estados Unidos - a contabilidade sobre resoluções da ONU que o Iraque teria descumprido. $\mathrm{O}$ fato de o Islã não ser mencionado em nenhum momento na reportagem, ao contrário do que aconteceu em dez dos demais treze textos analisados neste trabalho, pode também levar à impressão de que Veja suavizou sua posição na reprodução do discurso hegemônico norte-americano contra os muçulmanos. No entanto, o resultado presente na Tabela 14 mostra que a publicação, assim como nos textos anteriores, não abriu espaço ao contraditório, apresentando as posições de apenas um dos lados envolvidos na questão: do presidente norte-americano, George W. Bush, além dos aliados José María Aznar, que se apressou a dizer que apoiaria a ação militar americana, o Instituto Internacional de Estudos Estratégicos, da Inglaterra, principal parceira na invasão ao Iraque, o professor da Universidade de São Paulo José Augusto Guilhon de Albuquerque, que apenas reforçou o discurso de que os americanos precisam de aliados, de bases militares em outros países, de serviços de inteligência 
estrangeiros, e do presidente francês, Jacques Chirac. O relato da entrevista do presidente francês ao jornal The New York Times serve para evidenciar como o discurso indireto pode distorcer manifestações atribuídas dessa maneira. Ainda que Veja ressalte ser Chirac crítico severo da idéia americana de depor Saddam, o excerto que trata de sua manifestação foi estruturado assim: Chirac sugeriu aos americanos que pedissem primeiro à ONU que adotasse medidas contra Saddam. Se ele se negar a colaborar, seria mais fácil para Washington obter, se não o apoio com tropas, pelo menos certa neutralidade crítica das outras potências, incluindo a China e a Rússia. O primeiro ponto é que não se sabe se a declaração de Chirac se limitou a sugerir aos americanos que pedissem auxílio à Organização das Nações Unidas, ou se o pensamento do presidente francês se estende à possivel facilidade que teria o governo norte-americano de conseguir apoio militar ou neutralidade de outras nações. O segundo, e mais importante, é que na entrevista ao The New York Times ${ }^{91}$ em nenhum momento Chirac sugere aos Estados Unidos que peçam primeiro à ONU que adote medidas contra o Iraque. O que diz o presidente francês é: if a military action is to be undertaken, it must be the responsibility of the international community, via a decision by the Security Council. Now, the Security Council has decided that Iraq must not have weapons of mass destruction; it did not say that a regime change was necessary there. So if the objective is to prevent Iraq from having weapons of mass destruction, we have to go along with what the United Nations has done, that is, impose the return of inspectors in Iraq without restrictions or preconditions. . . If it refuses, then it's up to the Security Council to deliberate and decide what must be done and notably whether a military operation should be undertaken or not ${ }^{92}$. E também que there must be a Security Council decision concerning the return of the inspectors. . . If the inspectors are not allowed to return, then there should be a second Security Council resolution to say if there should be or not an intervention ${ }^{93}$.

\footnotetext{
${ }^{91}$ Disponível em: <http://www.nytimes.com/2002/09/09/world/threats-responses-perspectives-jacqueschirac-french-leader-offers-america-both.html?scp=2\&sq=Jacques\%20Chirac\&st=nyt\&pagewanted=1>. 92 "se um ataque está para ser empreendido, deve ser de responsabilidade da comunidade internacional, via decisão do Conselho de Segurança. Agora, o Conselho de Segurançadecidiu que o Iraque não não deve ter armas de destruição em massa; não disse que uma troca de regime seria necessária. Então se o objetivo é previnir que o Iraque tenha armas de destruição em massa, nós temos que seguir juntos com o que o Conselho de Segurança tem feito, que é impor a volta dos inspetores ao Iraque sem restrições ou pré-condições. Se o Iraque recusar, aí cabe ao ao Conselho de Segurança deliberar e decidir o que deve ser feito, especialmente se uma operação militar deve ser empreendida ou não"

93 “deve haver uma decisão do Conselho de Segurança a respeito do retorno dos inspetores...Se eles não forem autorizados a voltar, então deve haver uma segunda resolução do Conselho de Segurança para dizer se deve ou não haver uma intervenção"
} 
A Tabela 14 também mostra que Veja utilizou afirmações avaliativas e presunções valorativas para dar suporte ao discurso norte-americano, como quando diz que com sua posição, Bush pretende que a organização faça as exigências necessárias ao ditador. Ou seja, a revista toma como fato dado que as exigências são realmente necessárias, pois o presidente norte-americano assim o disse: "Nós trabalharemos com o Conselho de Segurança pelas resoluções necessárias [...]". Ao contrário do que fizeram publicações brasileiras, entre elas o jornal Folha de S.Paulo, Veja não publicou qualquer posição do governo iraquiano ou qualquer análise que contestasse os argumentos norte-americanos 9495 . A revista também toma como fato verdadeiro que os inspetores da ONU foram $\underline{\text { ludibriados pelos iraquianos, }}$ que têm ou estão tentando produzir um arsenal nuclear, químico e bacteriológico e, portanto, os EUA julgam com boas razões que eles têm muito a esconder. Os motivos norte-americanos não precisam ser evidenciados para ganharem apoio da publicação brasileira, para quem os norte-americanos ainda não têm como provar que atacaram em defesa própria. Ou seja, é uma questão apenas de tempo, pois as provas virão, pelo que se compreende do enunciado. Como é sabido, um relatório divulgado em outubro de 2004, assinado pelo chefe dos 1.400 inspetores responsáveis por vistoriar durante um ano e quatro meses o Iraque, Charles Duelfer, concluiu que o Iraque não tinha, pelo menos desde 1991, data do início da sanção imposta pela ONU ao país, qualquer arsenal ${ }^{96}$. O apoio de Veja também se mostra mais acrítico que a própria imprensa norte-americana. Em artigo publicado em 13 de setembro de 2002, The New York Times ${ }^{97}$ questiona a urgência da invasão. Veja também considera que a urgência não está clara, mas apenas para quem está fora do círculo íntimo da Casa Branca.

Por fim, é preciso considerar a questão econômica. Como a publicação deixa claro, $\underline{\mathrm{o}}$ que ninguém perde de vista é o petróleo. É ele que deixa os outros países temerosos dos efeitos globais de uma nova guerra no Oriente Médio, pois a simples notícia de que o Iraque havia rejeitado a volta dos inspetores fez o preço do petróleo fechar acima dos 28 dólares por barril, um salto de quase $3 \%$ em relação ao dia anterior. E, afinal, como ressalta a publicação, o Iraque tem a segunda maior reserva de petróleo do mundo, depois da Arábia Saudita. Os Estados Unidos são os maiores consumidores mundiais e

\footnotetext{
${ }^{94}$ Disponível em: <http://www1.folha.uol.com.br/fsp/mundo/ft1309200206.htm>.

${ }^{95}$ Disponível em: <http://www1.folha.uol.com.br/fsp/mundo/ft1409200203.htm>.

${ }^{96}$ Disponível em: <http://www1.folha.uol.com.br/fsp/mundo/ft0710200401.htm>.

${ }^{97}$ Disponível em: <http://www.nytimes.com/2002/09/13/opinion/the-guns-ofseptember.html scp=2\&sq=nicholas + d. + kristof $\&$ st $=$ nyt $>$.
} 
precisam importar mais da metade do que consomem. Europa e Japão são completamente dependentes do petróleo do Golfo Pérsico. Na visão de Veja, tal fato justifica qualquer ato. É motivo para depor Saddam e é razão para tratar com tanta cordialidade uma monarquia como a saudita, vista como corrupta e feudal. Com isso, cai por terra o discurso de que, além de destruir o imagindo arsenal iraquiano, os ataques teriam o objetivo de deter os atos de violência de Saddam Hussein contra o próprio povo. O cálculo se faz do ponto de vista dos interesses econômicos, tendo como meta principal reduzir as possibilidades de negociação dos árabes, pois o poder de barganha saudita seria bastante reduzido se o petróleo iraquiano pudesse chegar à vontade ao mercado mundial. Hoje, por causa do embargo ao Iraque, que só pode vender uma pequena parte do petróleo que produz, a Arábia Saudita tem mais controle do comércio mundial de óleo. Edward Said (1997) chama atenção para como, no contexto do comércio do petróleo entre países do Oriente Médio e o Ocidente, os estrategistas geopolíticos e intelectuais liberais fizeram uso dos países islâmicos. Segundo Said:

\begin{abstract}
It is not too much of an exaggeration to say that before the sudden OPEC prices rises in early 1974, 'Islam' as such scarcely figured either in the culture or in the media [...] But the dramatically higher cost of imported oil soon became associated in the public mind with a cluster of unpleasant things: American dependence on imported oil (which was usually referred to as 'being at the mercy of foreign oil producers'); the apprehension that intransigence was being communicated from the Middle East and Persian Gulf regions to individual Americans; above all a signal - as if from a new, hitherto unidentified force - saying that energy was no longer 'ours' for the taking. (1997, p. 36). ${ }^{98}$
\end{abstract}

Quando se trata dos países de maioria muçulmana, Veja não vê necessidade de qualquer conexão com a realidade; apenas hipóteses são suficientes. A revista pede para que o leitor imagine o cenário de pesadelo: acuado pelos Estados Unidos, Saddam poderia invadir a Arábia Saudita ou bombardear os campos petrolíferos do Kuwait. Nessa hipótese, o preço do barril poderia facilmente ultrapassar os 100 dólares e provocar um aprofundamento da recessão mundial. A imaginação da revista segue até ganhar

\footnotetext{
98 "Não é exagero dizer que antes da repentina elevação dos preços da OPECP no começo de 1974, 은ㅈã como tal -mal figurava na cultura ou na mídia [...] Mas o preço dramaticamente alto do petróleo importado logo ganhou associação na mente do público com um punhado de coisas desprazerosas: a

| dependência americana de petróleo importado (ea qual ganhou referência usual como 'estando à mercê de produtores de petróleo estrangeiros); a apreensão de estar sendo comunicada uma intransigência do Oriente Médio e Golfo Pérsico para americanos individualmente; e acima de tudo um sinal - como se de uma nova, até aqui não identificada força - dizendo que a energia não estava mais lá disponível para apenas pegá-la."
} 
contornos catastróficos, onde seria impossível manter o mundo árabe fora do conflito, envolvendo etnias rivais que iriam engalfinhar-se em uma guerra civil, o que faria Irã e $\underline{\text { Turquia }}$ ser obrigados a intervir, arrastados por rebeliões curdas e xiitas, o que aumentaria o conflito. Tal construção, para além de uma imaginação fértil e completamente desamparada de sustentação na realidade, abre caminho para o discurso de que reconstruir um país como o Iraque é uma tarefa ainda mais acidentada e difícil do que pôr ordem no Afeganistão, o que nos conduz ao âmbito do orientalismo, como descrito por Said (1990). Em seu primeiro capítulo, ele relata o pronunciamento realizado por Arthur James Balfour ${ }^{99}$ em 1910, na Câmara dos Comuns, no Reino Unido. Discorrendo sobre o Egito, o político pergunta:

É uma boa coisa para essas grandes nações - admito a grandeza delas - que esse governo absoluto seja exercido por nós? Acho que é uma boa coisa. Acho que a experiência demonstra que sob esse governo elas têm um governo muito melhor que qualquer outro que tenham tido em toda a história, o que é um benefício não só para elas, como sem dúvida para o conjunto do Ocidente civilizado. [...] Estamos no Egito não apenas pelo bem do Egito, apesar de estarmos lá para o bem deles; estamos lá também para o bem da Europa em geral. (SAID, 1990, p. 43).

Segundo Said,

Balfour não dá nenhuma prova de que os egípcios e "as raças com que tratamos" apreciam ou sequer entendem o bem que está sendo feito por eles por parte da ocupação colonial. Não lhe ocorre, contudo, deixar que o egípcio fale por si mesmo, visto que, presumivelmente, qualquer egípcio que venha falar será antes "o agitador (que) quer criar dificuldades" do que o bom nativo que faça vista grossa para as "dificuldades" da dominação estrangeira (1990, p. 44).

As teses de Balfour somam-se à prática de lord Cromer ${ }^{100}$, que administrou primeiro a Índia e depois o Egito, entre o final do século XIX e o início do XX. De acordo com Said, diferentemente de Balfour, cujas teses sobre os orientais tinham pretensões a uma universalidade objetiva, Cromer falava sobre os orientais como aquilo que ele teve que governar. E na linguagem de ambos:

[...] o oriental é apresentado como algo que se julga (como um tribunal), algo que se estuda e se descreve (como um currículo), algo que se disciplina (uma

\footnotetext{
${ }^{99}$ Arthur James Balfour, nascido na Escócia em 25 de julho de 1848, foi primeiro-ministro do Reino Unido. Conhecido por ter dado nome à Declaração Balfour, através da qual o governo britânico apoiou, em 1917, as aspirações sionistas para criação de um estado nacional judeu na Palestina.

${ }^{100}$ Evelyn Baring nasceu na Inglaterra em 26 de fevereiro de 1841, foi um estadista, diplomata e administrador colonial, autor de Modern Egypt.
} 
escola ou uma prisão), algo que se ilustra (como em um manual zoológico). A questão é que em cada um desses casos o oriental é contido e representado por estruturas dominantes. (SAID, 1990, p. 50-51).

Texto 15: Reportagem revista Veja edição 1770 - 25 de setembo de 2002.

\title{
RECUO DE SADDAM É POUCO PARA BUSH
}

\author{
Presidente americano não altera seus planos de guerra, mas o mundo \\ respira aliviado com o adiamento da batalha no Iraque
}

A decisão anunciada na segunda-feira passada pelo Iraque de aceitar de volta os inspetores da ONU, que expulsou de seu território em 1998, trouxe um sentimento de alivio aos países vizinhos. Todos sabem que a trégua é temporária e que tudo o que Saddam Hussein conseguiu foi adiar os planos de batalha do presidente George W. Bush - mas para aliados relutantes, especialmente os países arábes, o tempo extra pode ser uma oportunidade de ouro para encontrar outro meio de lidar com o ditador iraquiano sem que seja preciso recorrer à força. Quanto tempo Saddam ganhou com seu recuo tático? Os primeiros inspetores da ONU chegarão a Bagdá em 15 de outubro para preparar o plano de desarmamento do Iraque. As visitas técnicas para procurar e desmantelar o arsenal de armas de destruição em massa só começam em seis meses. $\mathrm{Na}$ quinta-feira passada, sem dar maior importância à mudança na retórica iraquiana, o presidente americano encaminhou ao Congresso um pedido de autorização para desarmar o Iraque "por todos os meios". Uma grande aliança com países europeus e árabes tinha se formado depois do discurso, na semana anterior, em que Bush entregou a questão do Iraque à ONU. Ele pediu que a organização forçasse Saddam a obedecer às resoluções tomadas pela própria organização. A mais importante delas era o retorno dos inspetores, expulsos do Iraque há quatro anos.

$O$ respaldo da ONU tinha consolidado a coalizão internacional anti-Saddam. Até a Arábia Saudita, relutante em entrar em conflito com um vizinho árabe, ofereceu seu território para ser usado como base pelos aviões americanos. $O$ recuo do ditador iraquiano deu uma ótima desculpa para que os aliados se distanciassem dos planos 
bélicos da Casa Branca. A aliança desmobilizou-se rapidamente. A França, a Rússia e a China - países com poder de veto nas decisões da ONU - passaram a liderar a turma do deixa-disso. Há um consenso mundial de que Saddam Hussein é uma fonte permanente de dor de cabeça diplomática e militar, e que o mundo seria muito melhor sem ele no poder. Mas a maioria dos países não está convencida da urgência em derrubá-lo do poder, preferindo usar a pressão diplomática como medida de contenção em lugar da força bruta. "Os aliados europeus e árabes dos EUA estão mais nervosos com o caubói no Salão Oval do que com o assassino no bunker de Bagdá”, escreveu o colunista do jornal The New York Times Maureen Dowd. "Temem mais o presidente que possui as verdadeiras bombas, não o predador que planeja fabricá-las." É fácil entender por que Saddam recuou. Pela primeira vez desde 1991, quando foi expulso do Kuwait, país que tinha invadido, o ditador viu-se diante de uma ameaça concreta de ataque militar. As dúvidas que cercam uma guerra contra o Iraque não são militares. Ninguém duvida de que a máquina de guerra americana pode triturar as forças iraquianas em curto espaço de tempo. A supremacia da tecnologia bélica foi demonstrada em três vitórias arrasadoras obtidas com grande rapidez: na Guerra do Golfo, em 1991, nos Bálcãs, em 1999, e no Afeganistão, no ano passado. O problema desta vez é o fato de o cenário do conflito ser o Oriente Médio, a região mais volátil do mundo. Derrubar Saddam poderia ser a parte fácil. O que viria depois é imprevisível. Não há democracia na região. Só ditadores, monarquias corruptas e aiatolás por todos os lados, gente que teme muito mais uma revolta doméstica que vizinhos malcomportados. Quando os americanos começarem a bombardear o Iraque, podem atingir campos de petróleo. Qualquer crise no combustível afeta toda a economia mundial, que já se encontra em recessão. A situação global fica pior se a guerra não for bem para os Estados Unidos. Isso porque a economia americana equivale a um terço do PIB mundial e funciona como a locomotiva da prosperidade global. Será possível evitar a guerra? Talvez não. Saddam logo tentará enganar os inspetores, como fez das outras vezes, forçando a ONU e os Estados Unidos a tomar uma atitude. Os americanos conhecem muito bem os maus hábitos de Saddam - durante dez anos, os Estados Unidos o sustentaram com armas e dinheiro na guerra contra o Irã. Só o estilo bruto de tirano tribal explica o fato de Saddam ter traído seus benfeitores e tentado tomar o Kuwait. Este é um país seco, implantado sobre um mar de petróleo, que os Estados Unidos estavam dispostos a defender a qualquer custo. Bush tem razão numa coisa: não vale a pena confiar em Saddam. O homem, além de cruel, é traiçoeiro. 
Figura 2: Enquadramento econômico

\section{O cenário econômico de uma guerra no Golfo Pérsico}

\begin{tabular}{|c|c|c|}
\hline \multicolumn{2}{|l|}{ PETRÓLEO } & ECONOMIA AMERICANA \\
\hline $\begin{array}{l}\text { O preço atual do petröleo } \\
\text { é de cerca de } 29 \text { dólares por } \\
\text { barril. Estima-se que durante } \\
\text { a guerra possa chegar } \\
\text { a } 40 \text { dólares. Com uma } \\
\text { vitória americana rápida, } \\
\text { é possivel que caia para } \\
20 \text { ou } 25 \text { dólares. Uma guerra } \\
\text { demorada e turbulenta teria } \\
\text { o efeito contrário, com } \\
\text { o preço do barril } \\
\text { ultrapassando } 60 \text { dólares }\end{array}$ & $\begin{array}{l}\text { Dono da segunda maior reserva } \\
\text { de petróleo, o Iraque produzia } \\
2 \text { milhöes de barris por dia em } \\
2000 \text {. Hoje, em virtude das sançóes } \\
\text { econömicas, vende apenas } 780000 \text {. } \\
\text { É táo pouco que o impacto } \\
\text { da suspensão do fornecimento } \\
\text { seria pequeno no mundo. Por outro } \\
\text { lado, se o lraque ficasse livre } \\
\text { de sançōes, poderia triplicar sua } \\
\text { produçäo em poucos meses, } \\
\text { barateando o preco global do barril }\end{array}$ & $\begin{array}{l}\text { - Com o barril a } 40 \text { dólares, o PIB americano pode cair 0,5\% } \\
\text { - Cada aumento de } 1 \text { dólar no preço do petróleo significa } \\
12 \text { bilhöes de dólares a mais por ano nas despesas dos } \\
\text { consumidores. O resultado poderia ser a recessáo } \\
\text { - Cada } 5 \text { dólares de aumento reduzem em } 2 \% \text { os lucros } \\
\text { anuais das empresas americanas } \\
\text { - O dólar pode perder valor. No pior cenário, valeria } 15 \% \\
\text { menos que o euro } \\
\text { - Uma vitória rápida na guerra pode animar os investidores } \\
\text { e fortalecer as bolsas de valores }\end{array}$ \\
\hline
\end{tabular}

\section{CRESCIMENTO GLOBAL}

- O Brasil produz $83 \%$ do petróleo que consome. A maior parte do que importa vem da África. Mas é vulnerável ao preço internacional: estima-se que 1 dólar de aumento no preço do barril durante um ano represente um rombo de 200 milhòes de dólares na balança comercial brasileira

- A Europa e o lapão importam muito petróleo do Golfo Pérsico, mas dispóem de reservas e de fontes alternativas de energia. Jà para Taiwan, Coréia do Sul e outros Tigres Asiáticos, 0 aumento súbito no preço do produto seria devastador

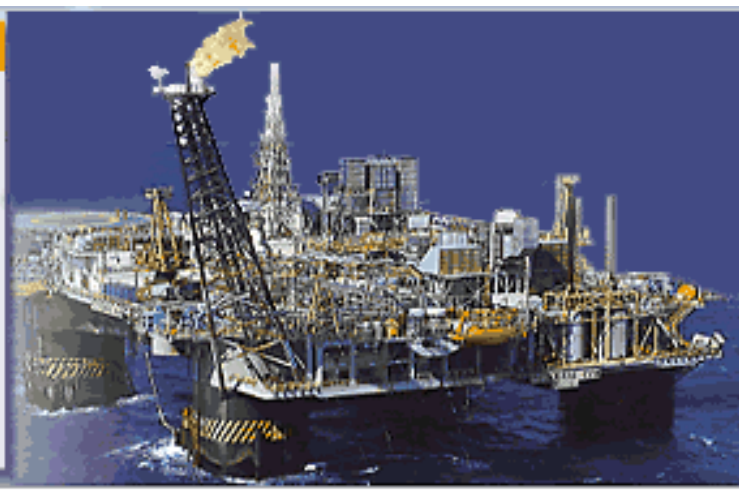

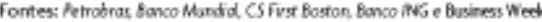

Tabela 15: Reportagem revista Veja edição 1770 - 25 de setembo de 2002.

\begin{tabular}{|l|l|}
\hline Discurso direto & $\begin{array}{l}\text { - Maureen Dowd, colunista do The New } \\
\text { York Times } \\
\text { - George W. Bush, presidente norte- } \\
\text { americano }\end{array}$ \\
\hline Discurso indireto & \begin{tabular}{l} 
- um sentimento de alívio aos países \\
vizinhos \\
\hline Pressuposições existenciais
\end{tabular} \\
\hline
\end{tabular}




\begin{tabular}{|c|c|}
\hline & $\begin{array}{l}\text { - desarmamento do Iraque } \\
\text { - } o \text { arsenal de armas de destruição em } \\
\text { massa } \\
\text { - } O \text { recuo do ditador iraquiano }\end{array}$ \\
\hline $\begin{array}{l}\text { Afirmações avaliativas/presunções } \\
\text { valorativas }\end{array}$ & $\begin{array}{l}\text { - encontrar outro meio de lidar com o } \\
\text { ditador iraquiano } \\
\text { - deu uma ótima desculpa para que os } \\
\text { aliados se distanciassem } \\
\text { - Há um consenso mundial de que Saddam } \\
\underline{\text { Hussein é uma fonte permanente de dor de }} \\
\underline{\text { cabeça diplomática e militar }} \\
\text { - } \underline{\text { o mundo seria muito melhor sem ele no }} \\
\text { poder } \\
\text { - o Oriente Médio, a região mais volátil do } \\
\underline{\text { mundo }} \\
\text { - Só ditadores, monarquias corruptas e } \\
\underline{\text { aiatolás por todos os lados }} \\
\text { - a economia americana [...] funciona } \\
\text { como a locomotiva da prosperida global } \\
\text { - Saddam logo tentará enganar os } \\
\text { inspetores } \\
\text { - Só o estilo bruto de tirano tribal explica } \\
\text { o fato de Saddam ter traído seus } \\
\text { benfeitores e tentado tomar o Kuwait } \\
\text { - não vale a pena confiar em Saddam. O } \\
\text { homem, além de cruel, é traiçoeiro }\end{array}$ \\
\hline
\end{tabular}


A unidade textual "Recuo de Saddam é pouco para Bush" repete posições encontradas no texto "Bush dá ultimato a Saddam". Veja novamente não menciona o Islã, mas reproduz o discurso norte-americano pró-ataque, procurando, através de afirmações avaliativas e presunções valorativas, reforçar a posição do presidente norteamericano, George W. Bush, enquanto enfraquece posições dos chamados países aliados, reticentes com relação à estratégia de ataque militar. A revista também despreza qualquer manifestação iraquiana.

A construção de tal discurso, que busca legitimar um ataque contra o Iraque - como deseja o presidente norte-americano, ainda que o tema não seja consensual -, utiliza como estratégia tomar como fato dado que o Iraque tem, indiscutivelmente, armas de destruição, o que se evidencia na afirmação de Veja de que os primeiros inspetores da ONU chegarão a Bagdá em 15 de outubro para preparar o plano de desarmamento do Iraque. As visitas técnicas para procurar e desmantelar o arsenal de armas de destruição em massa só começam em seis meses. A revista não toma qualquer cuidado em dizer que os inspetores vão ao Iraque à procura de um suposto arsenal de armas de destruição em massa que, como mencionado anteriormente, o país não tinha pelo menos desde 1991. Veja também não menciona, ao relatar que os inspetores foram expulsos do Iraque há quatro anos, a acusação de que eles teriam sido expulsos por estarem espionando para os Estados Unidos, como faz, por exemplo, a Folha de S.Paulo ${ }^{101}$. Para além de ser verdade ou não que os inspetores espionaram, tal escolha indica o posicionamento da revista de relatar apenas um dos discursos envolvidos na questão, reforçando a estratégia de legitimar um ataque norte-americano.

Veja se esforça para mostrar que o ataque é inevitável, que a trégua é temporária e que tudo o que Saddam Hussein conseguiu foi adiar os planos de batalha do presidente George W. Bush. Para a revista, o ataque é fato praticamente consumado, a posição iraquiana é apenas um recuo tático, tão-somente retórica iraquiana, pois $\underline{\text { Saddam logo }}$ tentará enganar os inspetores. Por conta disso, Veja infere que o reposicionamento iraquiano será usado pelos países aliados como uma desculpa para se distanciarem dos planos bélicos da Casa Branca. Uma vez que na língua portuguesa o substantivo feminino desculpa pode ser entendido como uma desculpa inadmissível ou incrível ${ }^{102}$, uma dedução possível da afirmação de Veja é que a maioria dos aliados está

\footnotetext{
${ }^{101}$ Disponível em: <http://www1.folha.uol.com.br/fsp/mundo/ft1709200201.htm>.

${ }^{102}$ Disponível em: <http://michaelis.uol.com.br/moderno/portugues/index.php?lingua=portuguesportugues\&palavra $=$ desculpa $>$.
} 
tergiversando, não está convencida da urgência em derrubá-lo do poder, apesar de haver um consenso mundial de que Saddam Hussein é uma fonte permanente de dor de cabeça diplomática e militar, e que o mundo seria muito melhor sem ele no poder. Para a revista, atacar o Iraque para derrubar Saddam Hussein é uma questão apenas de tempo. Veja reproduz trecho da coluna da jornalista Maureen Dowd, no The New York Time ${ }^{103}$, onde o presidente norte-americano é classificado como o caubói no Salão Oval e Saddam Hussein como o assassino no bunker de Bagdá. Ao longo do texto, enquanto a reportagem se refere a George W. Bush como o presidente, presidente americano, presidente George W. Bush, e Bush, o iraquiano é chamado de Saddam Hussein,

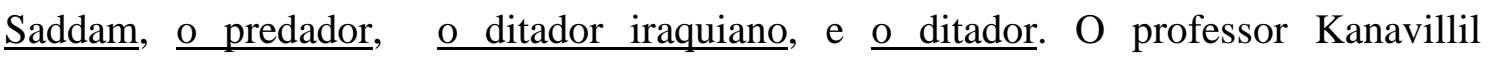
Rajagopalan (2003, p. 82) faz uma reflexão "sobre como a mídia imprime certas interpretações pelo simples ato de designação de determinados acontecimentos, dos responsáveis por tais acontecimentos, dos atos específicos praticados pelos lados em situações de conflitos etc.". Segundo ele, o uso político de nomes e apelidos é o primeiro passo da mídia para influenciar a opinião pública: “é preciso pensar além da semântica dos nomes próprios para encarar o fenômeno de nomeação como um ato eminentemente político".

Veja também volta a dar voz a apenas um dos lados envolvidos na questão, os Estados Unidos. Como é possível ver na Tabela 15, apenas o discurso do presidente norteamericano e a manifestação de uma jornalista americana são grafados no texto. Nenhum representante entre as chamadas nações aliadas, e muito menos do país que está prestes a ser invadido, foi ouvido ou se manifestou direta ou indiretamente no texto da publicação brasileira. Em Mídia e Guerra: enquadramentos do Iraque (2004), onde analisa a relação que se estabelece entre Estado, sociedade e meios de comunicação em situação de guerra, Alessandra Aldé diz que:

[...] uma cobertura democrática da política, em qualquer ocasição, implica a oferta, para a sociedade, de informação com pluralidade de enquadramentos. $\mathrm{O}$ fechamento de enquadramentos, numa guerra, pode levar no limite à adoção restrita da versão oficial, reduzindo a possibilidade dos cidadãos de elaborarem suas opiniões a partir da comparação entre diferentes aspectos e perspectivas sobre o conflito (2004, p. 6).

\footnotetext{
${ }^{103}$ Disponível em: <http://www.nytimes.com/2002/09/18/opinion/lemon-fizzes-on-the-banks-of-theeuphrates.html? scp=3\&sq=Maureen+Dowd\&st=nyt $>$.
} 
Em suas análises, Aldé aponta quatro enquadramentos principais, que revelam escolhas políticas implícitas no notíciário em momentos de guerra: enquandramento militar ou belicista, centrado em táticas, estratégias, arsenais e equipamentos militares; enquadramento econômico, focado nas motivações e consequências econômicas que se escondem atrás do conflito; enquandramento humanista, que se concentra nos efeitos da guerra sobre populações; por fim, o enquadramento político, que reúne os significados públicos da guerra, o exercício de poder e a tomada de decisões e seus efeitos para a ordem internacional. Analisando o posicionamento das edições de Veja publicadas no início do ano de 2003, a pesquisadora diz considerar que a publicação "foi exemplo da adoção da perspectiva militarista da guerra, embora oferecesse às vezes enquadramentos políticos e econômicos para avalizar a leitura de mundo que oferecia" (2004, p. 11). Os enquadramentos descritos por Aldé são encontrados também no corpus analisado nesta pesquisa, com a diferença de ter o enquadramento econômico importância igual ao militarista, como é possível ver no excerto que tem início em ninguém duvida de que a máquina de guerra americana pode triturar as forças iraquianas em curto espaço de tempo. A supremacia da tecnologia bélica foi demonstrada em três vitórias arrasadoras obtidas com grande rapidez: na Guerra do Golfo, em 1991, nos Bálcãs, em 1999, e no Afeganistão, no ano passado (enquadramento militarista), segue em o problema desta vez é o fato de o cenário do conflito ser o Oriente Médio, a região mais volátil do mundo. Derrubar Saddam poderia ser a parte fácil. O que viria depois é imprevisível. Não há democracia na região. Só ditadores, monarquias corruptas e aiatolás por todos os lados, gente que teme muito mais uma revolta doméstica que vizinhos malcomportados (enquadramento político) e chega a quando os americanos começarem a bombardear o Iraque, podem atingir campos de petróleo. Qualquer crise no combustível afeta toda a economia mundial, que já se encontra em recessão (enquadramento econômico). A força do enquadramento econômico pode ser percebida pelo boxe publicado junto à unidade textual (Figura 2), em que a revista destaca o que acredita serem as consequiências que o ataque norte-americano contra o Iraque traria ao comércio do petróleo e à economia do Brasil e dos Estados Unidos. 
Texto 16: Reportagem revista Veja edição 1771 - 2 de outubro de 2002.

\section{PAPAI ROUBOU 4 BILHÕES}

Herdeiro de ditador nigeriano desiste do acordo para devolver 1 bilhão de dólares ao governo

O nigeriano Sani Abacha foi um dos presidentes mais ladrões do mundo. O governo da Nigéria estima que tenha roubado pelo menos 4 bilhões de dólares entre 1993, quando tomou o poder num golpe militar, e 1998, ano de sua morte. Uma gigantesca busca internacional conduzida pelo banco central da Nigéria localizou 650 milhões de dólares em bancos suiços, 350 milhões em Liechtenstein e 250 milhões em Luxemburgo. O governo suíço disse que sem a assinatura de Mohamed Abacha, filho mais velho do ditador, pouco pode fazer para liberar o dinheiro. Em abril, foi anunciado um acordo com Mohamed. Pelo combinado, o governo deixaria a família do ditador ficar com 100 milhões de dólares, suspenderia definitivamente os processos judiciais e libertaria Mohamed, na cadeia por assassinato. Em troca, a família Abacha devolveria aos cofres do Tesouro a cifra de pouco mais de 1 bilhão de dólares depositados em bancos europeus. Na semana passada, o primogênito foi inocentado e posto em liberdade. Imediatamente, negou-se a cumprir sua parte no acordo. Mohamed ainda responde a 111 processos por roubo e lavagem de dinheiro e o governo já anunciou que vai reiniciar as ações legais para reaver a dinheirama. De acordo com o ranking da Transparência Internacional, a ONG devotada à promoção da honestidade, a Nigéria é um dos dois países mais corruptos do mundo. Mesmo pelos padrões locais, Abacha foi um exagero. O ditador pegava uma fatia grande de todo o dinheiro arrecadado com a venda de petróleo, o principal produto do país. Se as contas estão certas, no período em que ele esteve no governo, roubou no acelerado ritmo de 800 milhões de dólares por ano. Ele mandava caminhonetes buscar dinheiro no prédio do Tesouro nacional e entregá-lo na casa de familiares e amigos. A relação direta entre o índice de corrupção e péssimos índices sociais é didática no caso nigeriano. Sessenta e seis por cento da população de 117 milhões de habitantes vive com menos de 1 dólar 
por dia. A expectativa de vida das mulheres é de 56 anos e a dos homens, de 54 anos. Os conflitos tribais, num país com nada menos que 250 grupos étnicos, estão sempre em ebulição. A Nigéria é o décimo produtor mundial de petróleo, mas é obrigada a importar a maior parte dos produtos que consome porque tem poucas indústrias. No ano passado, o governo resolveu adotar a operação "inspeção 100\%" nas fronteiras, numa tentativa de combater o contrabando, outra chaga do país. Em vez de pagarem os impostos, os importadores abandonaram as mercadorias, paralisaram os portos $e$ forçaram o governo a voltar atrás.

Tabela 16: Reportagem revista Veja edição 1771 - 2 de outubro de 2000.

\begin{tabular}{|c|c|}
\hline Discurso direto & \\
\hline Discurso indireto & $\begin{array}{l}\text { - governo da Nigéria } \\
\text { - governo suíço } \\
\text { - Transparência Internacional }\end{array}$ \\
\hline Pressuposições existenciais & \\
\hline $\begin{array}{l}\text { Afirmações avaliativas/presunções } \\
\text { valorativas }\end{array}$ & $\begin{array}{l}\text { - O nigeriano Sani Abacha foi um dos } \\
\text { presidentes mais ladrões do mundo } \\
\text { - A relação direta entre o índice de } \\
\text { corrupção e péssimos índices sociais é } \\
\text { didática no caso nigeriano }\end{array}$ \\
\hline
\end{tabular}

A análise da unidade textual e do contexto em que é publicada vai de encontro com os resultados encontrados na análise quantitativa, que mostram que o interesse e o tratamento dado aos países de maioria muçulmana são diferentes em momentos em que há violência ou a iminência de ação violenta envolvendo os Estados Unidos. Também mostra que a citação ao Islã está diretamente associada à violência e a costumes estranhos ao Ocidente, mas não a questões como corrupção, por exemplo, presentes na realidade não apenas dos países de maioria islâmica. 
O que não muda é o olhar para o outro, a maneira como o outro é previamente enquadrado, pois a Nigéria é um dos dois países mais corruptos do mundo. E, segundo Veja, mesmo pelos padrões locais, Abacha foi um exagero. Ou seja, não era um governo ou governante corrupto, é a Nigéria que é um país corrupto, que exibe padrões de corrupção aceitáveis para o que são os nigerianos. Veja desconsidera completamente o fator histórico, em especial a história da colonização inglesa, que se estendeu até 1960. É o discurso orientalista operando, os objetos são o que são porque são o que são e nada poderá alterar isso (SAID, 1990, p. 80).

Veja também não se preocupou em ouvir alguém que não represente a voz oficial a designar os fatos. Nenhum discurso direto é encontrado na reportagem. As manifestações, em discurso indireto, vêm, além da ONG Transparência Internacional, dos governos da Suíça e da Nigéria. 


\section{Capítulo IV - Análise quantitativa}

\section{1 - Definição e coleta do corpus}

A escolha de Veja deu-se por ela registrar, como explicitado na introdução desta dissertação, a maior tiragem entre as publicações noticiosas brasileiras, com média registrada em junho de 2010 de 1.097 .490 exemplares por semana, o que a coloca como a maior do Brasil em circulação e a terceira maior do mundo, atrás apenas de Time e Newsweek, segundo informações da Editora Abril através de sua assessoria de imprensa.

$\mathrm{O}$ corpus desta pesquisa reúne doze edições da revista Veja: quatro edições publicadas exatamente um ano antes do 11 de setembro (1 666, de 13 de setembro de 2000; 1 667, de 20 de setembro de 2000; 1 668, de 27 de setembro de 2000; 1 669, de 4 de outubro de 2000), mais quatro edições publicadas nas semanas imediatamente após o 11 de setembro ( 1718 , de 19 de setembro de 2001; 1 719, de 26 de setembro de 2001; 1 720, de 3 de outubro de 2001; 1721 , de 10 de outubro de 2001), e ainda quatro edições publicadas exatamente um ano após o 11 de setembro (1 768, de 11 de setembro de 2002; 1769 , de 18 de setembro de 2002; 1770 , de 25 de setembro de 2002; 1771 , de 2 de outubro de 2002). Tal recorte foi definido para que pudéssemos medir a variação de interesse da revista em assuntos relacionados a países de maioria muçulmana. Com a certeza de que eles estariam amplamente presentes nos dias que se seguiram ao 11 de setembro, consideramos importante ter clareza sobre o quão importantes tais assuntos pareciam antes dos trágicos eventos em Nova York e quanto do interesse foi perdido um ano após os ataques às torres gêmeas. Para tanto, utilizamos como base comparativa, além dos números absolutos, também a avaliação da proporcionalidade, tendo como parâmetro o total de reportagens que trataram de temas internacionais nas páginas da revista. Também consideramos fundamental verificar se a religião muçulmana aparece ligada aos eventos de violência do 11 de setembro. Para tanto, realizamos a medição do número de vezes que o Islã é citado nas reportagens nos três diferentes períodos.

Como critério de análise, foi estabelecido que cada texto equivale a uma unidade informativa. Foram consideradas unidades informativas os textos que tenham um título, ou o que no jargão jornalístico é chamado de manchete. Seja uma reportagem extensa ou uma nota, expressão também corrente no jargão jornalístico, cada texto foi considerado uma unidade textual e assim contabilizado. $\mathrm{O}$ recurso gráfico, chamado em 
algumas empresas jornalísticas de boxe, que consiste em um excerto de texto dentro de uma reportagem, ainda que também apresente título ou manchete, não foi considerado como unidade textual, mas sim como parte integrante do texto. Também não foram contabilizados gráficos que ilustram reportagens, assim como a seção denominada Cotações, por estarem basicamente restritos a números e recursos visuais. Optamos também por não considerar como unidade textual as capas das edições, por entendermos que a composição das mesmas se dá na combinação de textos e fotografias, o que nos obrigaria a efetuar uma análise diferenciada. Também achamos por bem deixar de fora seções que pouca ação registram dos jornalistas do veículo, apesar do trabalho de edição que certamente se configura nas mesmas. É o caso da seção Cartas, onde aparecem opiniões e comentários de leitores da revista sobre reportagens publicadas em edições anteriores ou assuntos em pauta nos dias que precederam a edição corrente. Também da seção chamada $O$ que estou lendo, que, como o próprio nome indica, apresenta dicas de leitura de pessoas que frequentam o noticiário. Ainda a seção Sobe Desce, que registra pessoas ou instituições que, na visão da revista, estão em destaque. E, por fim, as seções Veja Online, por apresentar textos que apenas remetem à unidade textual completa que pode ser encontrada no site da revista; Veja Essa, que consiste basicamente de frases de políticos, artistas, músicos, entre outras pessoas que frequentam o noticiário, registradas pela revista ao longo da semana; e a seção Arc, coleção de textos que contam histórias de um fictício marciano que, em visita à Terra, estranha algumas ações que por aqui testemunha. Essas duas últimas ficaram de fora pelo fato de só aparecerem em duas das edições analisadas, ambas do ano de 2002.

Depois de registrar o total de unidades textuais publicadas em cada edição de Veja, contabilizamos quantas dessas unidades textuais tratavam do noticiário internacional. Como muitas reportagens trazem elementos de informação que tratam tanto de questões internacionais quanto nacionais, em alguns momentos foi necessária uma combinação de critérios para se definir se a reportagem se enquadraria entre noticiário nacional ou internacional. $\mathrm{O}$ primeiro desses critérios foi a identificação do local dos acontecimentos relatados na reportagem. Se o fato narrado toma lugar no Brasil, a reportagem foi definida como de cunho nacional; se o fato ocorreu no exterior, esse foi considerado um primeiro indicativo de cunho internacional. Essa, no entanto, não poderia ser uma regra inflexível e única. No caso da cobertura das Olimpíadas de Sidney, na Austrália, por exemplo, foram publicadas oito reportagens nas quatro edições do ano de 2000 analisadas neste trabalho. Apesar de todas estarem relacionadas 
com um evento ocorrido no exterior, foi preciso um detalhamento específico para poder definir o posicionamento de cada uma. A primeira das reportagens, publicada na edição 1666 com o título As lições de Sydney para sua Saúde, não tratou especificamente das provas esportivas, mas, como o próprio título deixa claro, da relação da medicina com o esporte. Poderia, com uma análise superficial, ser enquadrada tanto em uma quanto em outra posição. Foram, então, analisadas as fontes utilizadas pela reportagem. Contabilizados, foram retratados quatro atletas, três especialistas e uma universidade estrangeiros contra três especialistas e um esportista brasileiros, que, no caso, não era atleta de uma modalidade olímpica, mas sim piloto de Fórmula 1, Rubens Barrichelo. O resultado de oito fontes estrangeiras contra quatro brasileiras em uma reportagem que tinha como mote um evento internacional apontou o enquadramento para um enfoque internacional da reportagem. No balanço geral da cobertura realizada pela revista Veja sobre as Olimpíadas de Sydney, cinco reportagens foram enquadradas no noticiário nacional e três no internacional.

Contabilizadas quantas das reportagens publicadas em cada edição de Veja tratavam do noticiário internacional, passamos então a analisar quantos dos textos fizeram menção a países de maioria muçulmana ou pessoas que professam a fé islâmica, além de utilizarem termos ligados à religião muçulmana, como xiita, por exemplo. Foi contabilizado ainda quantos textos trataram especificamente de países de maioria muçulmana ou pessoas ligadas à religião, além de contabilizar quantas dessas unidades textuais fizeram menção à religião islâmica. Os países considerados são os 22 integrantes da Liga dos Estados Árabes, ou seja, Sudão, Marrocos, Argélia, Tunísia, Egito, Líbia, Arábia Saudita, Kuwait, Emirados Árabes Unidos, Bahrein, Iraque, Líbano, Síria, Territórios Palestinos, Jordânia, Iêmen, Omã, Qatar, Mauritânia, Somália, Djibuti e República Islâmica Federal de Comoros (HIRO, 1996, p. 22 apud SOMMA, 2007, p. 15), mais Albânia, Bósnia-Herzegovina, Azerbaijão, Turcomenistão, Uzbequistão, Cazaquistão, Quirguistão, Tadjiquistão, Bangladesh, Brunei, Burkina Fasso, Indonésia, Malásia, Paquistão, Afeganistão, Saara Ocidental, Mali, Chade, Eritreia, Etiópia, Uganda, Tanzânia, Gâmbia, Guiné-Bissau, Guiné, Serra Leoa, Costa do Marfim, Togo, Benin, Níger, Nigéria, Senegal, Turquia, Irã (FARAH, 2001, p. 30$31)$.

Esse trabalho também se dedicou a contabilizar as fontes às quais Veja atribui a origem das notícias e fotos internacionais publicadas em suas páginas, além de 
contabilizar o volume de informações sem fonte identificada pela publicação. Combinar o levantamento das fontes de notícias e fontes fotográficas teve como estratégia complementar a análise qualitativa no que tange à interdiscursividade na publicação brasileira. Partimos do pressuposto de que em Veja as unidades textuais que tratam de temas internacionais - e em especial dos países de maioria muçulmana - se constroem a partir das informações produzidas no exterior e de lá transmitidas pelas agências internacionais de notícias, por jornais, revistas e redes de televisão, especialmente norteamericanas, apesar de a revista não explicitar esse fato para o leitor que desconhece os modos de produção jornalísticos. Assim, achamos necessário identificar e quantificar o país de origem das fontes que ganham direito a voz nas páginas da revista (Tabela $21 \mathrm{e}$ Figura 4). Acreditamos que tal prática não constitua solitariamente a explicação do motivo para a revista reproduzir o discurso hegemônico norte-americano, mas que represente fator significativo para tal. E uma vez que o volume de informações estampadas nas páginas de Veja sem que sua origem seja apresentada ao leitor é muito superior ao de informações com fonte identificável (Tabelas 24, 25, 26 e 27, e Figuras 5, 6, 7 e 8), consideramos também adequado estabelecer uma comparação com a prática executada com a identificação de autoria das fotografias que ilustram as reportagens (Tabelas 28, 29, 30 e 31, e Figura 9). Os objetos, cenários e pessoas retratados nas fotografias não foram analisados, apenas a autoria do trabalho, como condizente com nossa proposta. Optamos também por publicar apenas os dados relativos às seis agências fotográficas que mais apareceram no levantamento, por elas representarem maioria absoluta entre as mais de duas dezenas registradas na contabilidade dos dados. No caso das fontes que fornecem informações para os textos, o levantamento se dividiu em cinco categorias: agência de notícias, outros veículos, correspondente, fonte primária e não identificada. É importante que se diga que como correspondente foram compreendidos os textos que sinalizavam abaixo do nome do jornalista responsável pelo texto a cidade do exterior de onde ele assinou a reportagem em questão. Os textos assinados por um jornalista sem identificação de uma cidade no exterior foram entendidos como reportagens realizadas no Brasil, portanto, dependentes de fontes externas. Como fonte primária foram entendidas as unidades textuais que atribuíam claramente as informações constantes em seu corpo a alguma instituição ou órgão que não um veículo de comunicação ou agência de notícias internacional. As fontes fotográficas foram utilizadas como parâmetro de comparação, uma vez que sabíamos que elas são em sua imensa maioria devidamente creditadas aos seus autores. 


\section{2 - Dados das publicações pré-11 de setembro - Edições 1 666, 1 667,1668 e 1669}

Como mostra a Tabela 17, no período pré-11 de setembro, nas quatro edições do ano 2000 analisadas neste trabalho, Veja publicou 467 unidades textuais. Dessas, 141 trataram de temas internacionais, $30 \%$ do total. Ainda nesta tabela, observamos que apenas 19 unidades textuais faziam menção a países de maioria muçulmana ou pessoas que professam a fé islâmica, ou seja, $4 \%$ do total. Apenas seis unidades textuais trataram especificamente de algum país de maioria muçulmana, o que resulta em cerca de $1 \%$ do total das unidades textuais publicadas nas quatro edições, mesma proporção de unidades que citaram o Islã. Tais dados são importantes para comparação com o período de publicações exatamente após os ataques de 11 de setembro.

Tabela 17: Distribuição das unidades textuais para o ano de 2000 de acordo com a quantidade de textos total.

\begin{tabular}{l|cccc|cc}
\hline & \multicolumn{3}{c}{ Edição } & \multicolumn{2}{c}{ Total } \\
\cline { 2 - 5 } & $\mathbf{1 6 6 6}$ & $\mathbf{1 6 6 7}$ & $\mathbf{1 6 6 8}$ & $\mathbf{1 6 6 9}$ & Freq. & $\%$ \\
\hline Internacional & 26 & 43 & 38 & 34 & $\mathbf{1 4 1}$ & $\mathbf{3 0}$ \\
Pessoa/país/termo muçulmano & 5 & 6 & 4 & 4 & 19 & 4 \\
Específico & 1 & 2 & 1 & 2 & 6 & 1 \\
Religião & 1 & 0 & 1 & 2 & 4 & 1 \\
Outros & 81 & 71 & 69 & 76 & 297 & 64 \\
\hline Total unidades textuais & 114 & 122 & 113 & 118 & 467 & 100 \\
\hline
\end{tabular}




\section{3 - Dados das publicações imediatamente após 11 de setembro -}

Edições 1 718, 1 719, 1720 e 1721

Como demonstra a Tabela 18, no período imediatamente posterior ao 11 de setembro, nas quatro edições do ano 2001 analisadas neste trabalho, houve uma redução significativa no total de textos publicados, o que se explica pela maior concentração em um só assunto, ou seja, os ataques do 11 de setembro. É possível observar também um aumento significativo no número de textos que faziam menção a países de maioria muçulmana, pessoas que professam a fé islâmica e de textos que citam a religião muçulmana, passando de 4\% do total nas edições do ano 2000 para $21 \%$ do total agora, assim como um crescimento no número de vezes que o Islã é diretamente citado, subindo de $1 \%$ para $14 \%$. Tal quadro explicita que a revista, como era de se esperar, dedicou a maior parte de sua cobertura, cerca de $85 \%$, aos atentados contra o World Trade Center e o Pentágono, e que cresceu a menção direta ao Islã de maneira geral. O número proporcional de reportagens que tratam especificamente de algum país de maioria muçulmano segue o mesmo. Estabelecendo uma comparação entre as quatro edições do período de 2001, é possível notar que quanto mais próximo do 11 de setembro menor é o número de unidades textuais. Ou seja, o número de textos que preenchem o noticiário cai de maneira expressiva na primeira edição a tratar do assunto e, conforme a data dos atentados se distancia, a revista vai aumentando as unidades textuais que aparecem em suas páginas. Já o número de menções a pessoas e países ligados ao Islã, e também as referências diretas à religião, não estabelecem variação semelhante, seguindo em posição proporcionalmente maior que nas publicações do ano 2000.

Tabela 18: Distribuição das unidades textuais para o ano de 2001 de acordo com a quantidade de textos total.

\begin{tabular}{l|cccc|cc}
\hline \multirow{2}{*}{\multicolumn{1}{c}{2001}} & \multicolumn{3}{c}{ Edição } & \multicolumn{2}{c}{ Total } \\
\cline { 2 - 5 } & $\mathbf{1 7 1 8}$ & $\mathbf{1 7 1 9}$ & $\mathbf{1 7 2 0}$ & $\mathbf{1 7 2 1}$ & Freq. & \% \\
\hline Internacional & 22 & 19 & 19 & 20 & 80 & 29 \\
Pessoa/país/termo muçulmano & 11 & 16 & 16 & 16 & 59 & 21 \\
Específico & 1 & 2 & 1 & 0 & 4 & 1 \\
Religião & 7 & 10 & 12 & 11 & 40 & 14 \\
Outros & 7 & 7 & 38 & 44 & 96 & 35 \\
\hline Total unidades textuais & 48 & 54 & 86 & 91 & 279 & 100 \\
\hline
\end{tabular}




\section{4 - Dados das publicações um ano após 11 de setembro - Edições 1}

768, $1769,1770,1771$

Observando a Tabela 19, no período um ano depois do 11 de setembro, nas quatro edições analisadas percebe-se que Veja apresenta proporções semelhantes às edições do ano 2000, antes dos atentados. Na comparação entre os períodos mais distantes do 11 de setembro, caiu, proporcionalmente, o número de textos dedicados a assuntos internacionais, de $30 \%$ para $22 \%$. Mas o número de unidades textuais que fazem menção a países de maioria muçulmana, pessoas que professam a fé islâmica e de textos que citam a religião muçulmana voltam a se colocar no mesmo patamar, $4 \% \mathrm{em}$ 2000 e 6\% em 2002. O mesmo acontece com o número de vezes que o Islã é diretamente citado, $1 \%$ em 2000 e $2 \%$ em 2002, e com o volume de reportagens que tratam especificamente de países de maioria muçulmana: 1\% em 2000 e 2\% em 2002.

As edições apresentam um mesmo padrão de unidades textuais para todo o período analisado, assim como para unidades com referência a assuntos internacionais, países de maioria muçulmana, pessoas que professam a fé islâmica e de textos que citam a religião muçulmana.

Tabela 19: Distribuição das unidades textuais para o ano de 2002 de acordo com a quantidade de textos total.

\begin{tabular}{l|cccc|cc}
\hline \multirow{2}{*}{\multicolumn{1}{c}{2002}} & \multicolumn{3}{c}{ Edição } & \multicolumn{2}{c}{ Total } \\
\cline { 2 - 5 } & $\mathbf{1 7 6 8}$ & $\mathbf{1 7 6 9}$ & $\mathbf{1 7 7 0}$ & $\mathbf{1 7 7 1}$ & Freq. & \% \\
\hline Internacional & 19 & 21 & 21 & 21 & 82 & 22 \\
Pessoa/país/termo muçulmano & 6 & 8 & 6 & 4 & 24 & 6 \\
Específico & 5 & 0 & 1 & 1 & 7 & 2 \\
Religião & 0 & 5 & 1 & 1 & 7 & 2 \\
Outros & 63 & 61 & 65 & 68 & 257 & 68 \\
\hline Total unidades textuais & 93 & 95 & 94 & 95 & 377 & 100 \\
\hline
\end{tabular}




\section{5 - Comparação dos dados das publicações em três períodos}

Pela Tabela 20, podemos observar com maior clareza a diferença entre o enfoque das publicações no pré-atentados, na época dos atentados e pós-atentados. Ao colocar o foco no total das quatro edições publicadas no pré-11 de setembro e compará-las com o total das quatro edições lançadas imediatamente após os ataques contra os Estados Unidos, veremos que o total de unidades textuais caiu de 467 para 279, cerca de $40 \%$. Consequentemente, o número de textos dedicados aos assuntos internacionais também caiu, porém, a proporção de $30 \%$ se manteve. A proporção de vezes que alguma reportagem se voltou a um país muçulmano de maneira específica manteve-se em 1\%, o que indica que não há um interesse direto da revista por esses países, apenas no contexto de eventos que liguem a região aos países do Ocidente. Os maiores contrastes puderam ser observados no número de vezes que pessoas e países foram citados, com um aumento de 17 pontos percentuais, e para o número de vezes que a religião islâmica foi citada, 13 pontos percentuais. Como é comum em coberturas de eventos de tal impacto mundial, a revista concentrou grande parte dos seus esforços e atenção sobre os fatos ligados aos ataques.

Para o ano de 2002, o número de unidades textuais teve um aumento de $35 \%$, corroborando as análises anteriores. A proporção de unidades textuais referentes a assuntos internacionais teve uma queda de cerca 8 pontos percentuais em relação aos períodos anteriores, porém, para assuntos referentes ao mundo islâmico/muçulmano retornou ao padrão de 2000, pré-atentado.

Consolidados os dados dos três períodos analisados, é possível observar o movimento registrado na cobertura de Veja no que diz respeito ao Islã e aos muçulmanos (Tabela 20 e Figura 3). Pelo gráfico, podemos perceber que a distribuição de assuntos entre os três anos se diferencia exclusivamente pelo ano de 2001, nos dias que se seguiram ao 11 de setembro. Isso ocorre especialmente nas unidades textuais que citam o Islã diretamente, passando de 1\% em 2000 para 14\% em 2001, logo após o 11 de setembro, e baixando para $2 \%$ em 2002; e também nos textos que citam pessoa, país ou termo ligado ao islamismo, que somam 4\% em 2000, $21 \%$ em 2001, e caem para $6 \%$ em 2002. Ou seja, o Islã mais aparece quanto maior for a violência relatada nas reportagens. Por outro lado, as reportagens que tratam especificamente de países de maioria muçulmana permanecem em patamar bastante semelhante nos três períodos, $1 \% \mathrm{em}$ 
2000, $1 \%$ em 2001, e 2\% em 2002, o que indica, como já mencionado aqui, que o que interessa a Veja não são os países de maioria muçulmana, mas sim atos de violência de pessoas que têm origem nesses países.

Tabela 20: Distribuição das unidades textuais para os três anos em estudo.

\begin{tabular}{l|cccccc}
\hline & \multicolumn{2}{c}{$\mathbf{2 0 0 0}$} & \multicolumn{2}{c}{2001} & \multicolumn{2}{c}{$\mathbf{2 0 0 2}$} \\
\cline { 2 - 7 } & Freq. & \% & Freq. & \% & Freq. & \% \\
\hline Internacional & 141 & 30 & 80 & 29 & 82 & 22 \\
Pessoa/país/termo muçulmano & 19 & 4 & 59 & 21 & 24 & 6 \\
Específico & 6 & 1 & 4 & 1 & 7 & 2 \\
Religião & 4 & 1 & 40 & 14 & 7 & 2 \\
Outros & 297 & 64 & 96 & 35 & 257 & 68 \\
\hline Total & 467 & 100 & 279 & 100 & 377 & 100 \\
\hline
\end{tabular}

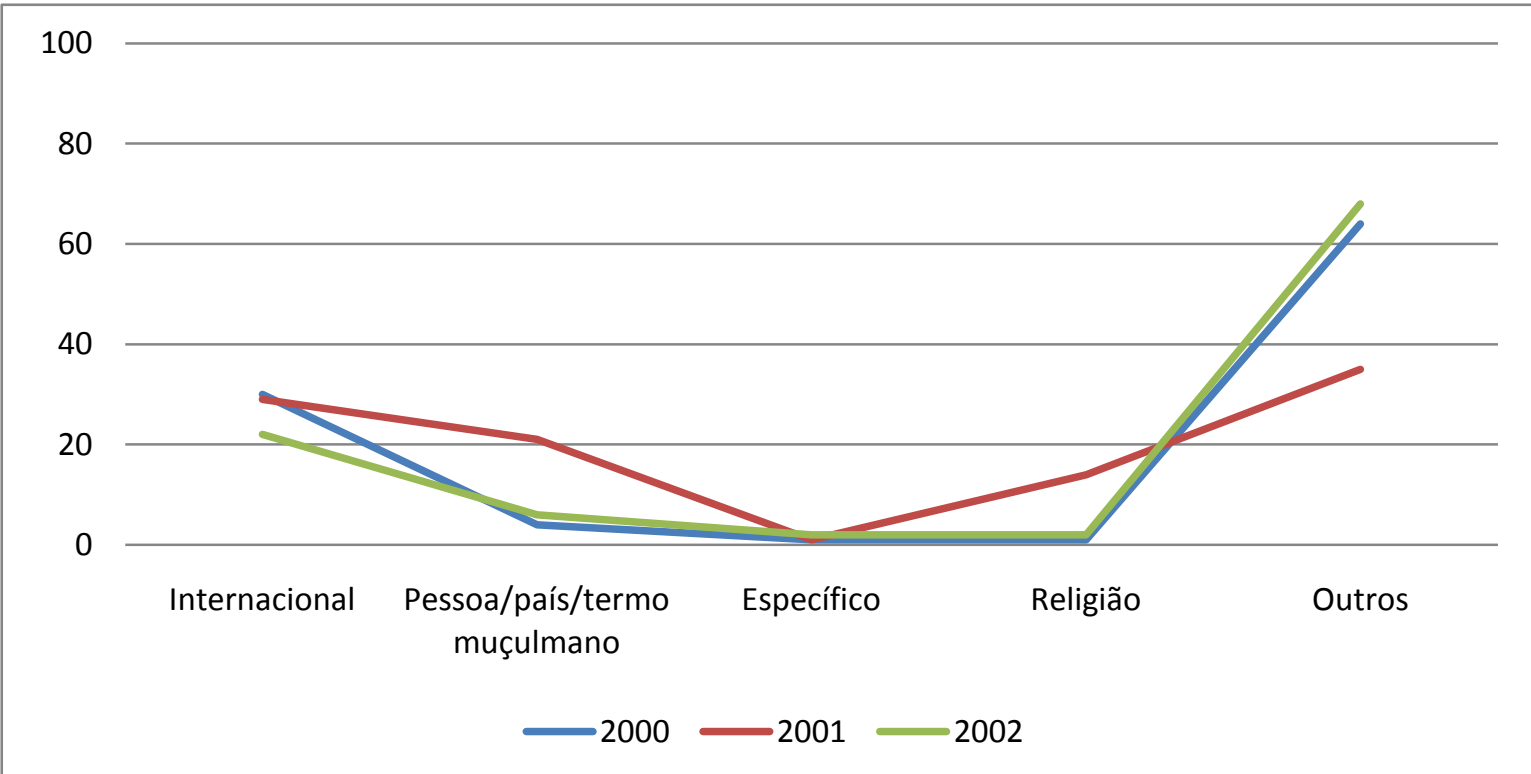

Figura 3: Gráfico da distribuição percentual para assuntos em estudo citados nos anos de 2000, 2001 e 2002. 


\section{6 - Quem fala em Veja}

Em A Ordem do discurso (1996), Michel Foucault faz uma reflexão sobre a produção do discurso. Segundo o filósofo francês, em toda sociedade ela é, ao mesmo tempo, controlada, selecionada, organizada e redistribuída por procedimentos, entre eles o da exclusão, sendo o mais familiar desses a interdição: "Sabe-se bem que não se tem o direito de dizer tudo, que não se pode falar de tudo em qualquer circunstância, que qualquer um, enfim, não pode falar de qualquer coisa” (1996, p. 9). Diante disso, contabilizamos quem fala em Veja, ou seja, quem tem direito à fala, quem ganha o direito de expor suas opiniões nas páginas da publicação, assim como registramos a quem é negado esse acesso e, consequentemente, que posicionamentos deixam de aparecer na revista. Além disso, observamos de que maneira o discurso é organizado e apresentado aos leitores, seja através do discurso direto ou indireto dos personagens ouvidos por Veja, ou através das operações discursivas pressupostos existenciais, afirmações avaliativas e presunções valorativas. A maneira como o discurso é organizado e apresentado foi analisada qualitativamente no Capítulo III desta dissertação.

Tabela 21: Países citados.

\begin{tabular}{l|cccccc}
\hline & \multicolumn{2}{c}{$\mathbf{2 0 0 0}$} & \multicolumn{2}{c}{$\mathbf{2 0 0 1}$} & \multicolumn{2}{c}{$\mathbf{2 0 0 2}$} \\
\cline { 2 - 7 } & Freq. & \% & Freq. & \% & Freq. & \% \\
\hline Estados Unidos & 0 & 0 & 18 & 53 & 8 & 53 \\
Europa & 0 & 0 & 10 & 29 & 3 & 20 \\
Brasil & 3 & 75 & 2 & 6 & 1 & 7 \\
Israel & 0 & 0 & 1 & 3 & 1 & 7 \\
Naís de mão identificado muçulmana & 1 & 25 & 2 & 6 & 2 & 13 \\
\hline Total & 0 & 0 & 1 & 3 & 0 & 0 \\
\hline & 4 & 100 & 34 & 100 & 15 & 100 \\
\hline
\end{tabular}


Tabela 22: Tipo de discurso da unidade textual.

\begin{tabular}{l|cccccc}
\hline \multirow{2}{*}{ Tipo de discurso } & \multicolumn{2}{c}{2000} & \multicolumn{2}{c}{$\mathbf{2 0 0 1}$} & \multicolumn{2}{c}{$\mathbf{2 0 0 2}$} \\
\cline { 2 - 7 } & Freq. & \% & Freq. & \% & Freq. & \% \\
\hline Direto & 4 & 100 & 35 & 75 & 5 & 29 \\
Indireto & 0 & 0 & 12 & 25 & 12 & 71 \\
\hline Total & 4 & 100 & 47 & 100 & 17 & 100 \\
\hline
\end{tabular}

Tabela 23: Operações discursivas.

\begin{tabular}{l|cccccc}
\hline & \multicolumn{2}{c}{$\mathbf{2 0 0 0}$} & \multicolumn{2}{c}{$\mathbf{2 0 0 1}$} & \multicolumn{2}{c}{$\mathbf{2 0 0 2}$} \\
\cline { 2 - 7 } & Freq. & $\mathbf{\%}$ & Freq. & \% & Freq. & \% \\
\hline $\begin{array}{l}\text { Pressupostos existenciais } \\
\begin{array}{l}\text { Afirmações avaliativas/presunções } \\
\text { valorativas }\end{array}\end{array}$ & 5 & 16 & 24 & 21 & 25 & 42 \\
\hline Total & 32 & 84 & 91 & & 34 & \\
\hline
\end{tabular}

Na Tabela 21, podemos observar o país de origem da maioria das fontes citadas por Veja nas unidades textuais sobre as quais foi aplicada a análise qualitativa nos três anos de enfoque. $\mathrm{O}$ ano 2000 teve citações apenas em relação ao Brasil e a países de maioria muçulmana, porém como seu volume é extremamente reduzido, focamos na comparação dos anos 2001 e 2002. É possível observar que mais de 50\% dos entrevistados por Veja para tratar de assuntos relacionados a países de maioria islâmica ou pessoas que professam sua fé no islamismo são norte-americanos, 53\% tanto em 2001 quanto em 2002. Europeus somam também grande proporção das fontes de Veja, $29 \%$ em 2001 e $20 \%$ em 2002. E os dados apontam que no período mais próximo ao 11 de setembro, quando o Islã era mais citado, foi quando representantes de países de maioria muçulmana foram menos ouvidos pela publicação. A escala de porcentagem da Figura 4 foi reduzida a fim de facilitar a análise visual da variação entre os anos. 


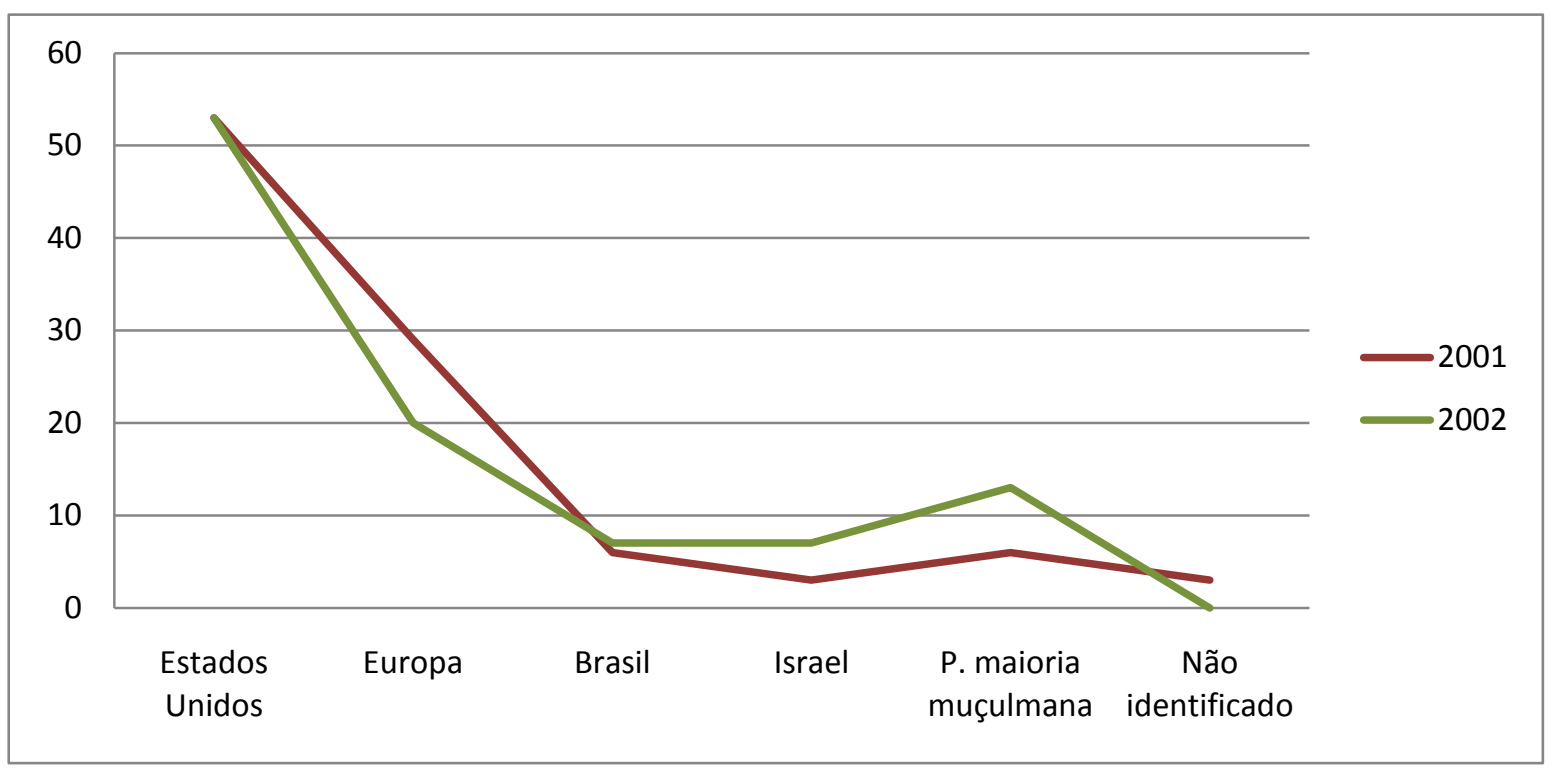

Figura 4: Distribuição percentual para países citados nos anos de 2001 e 2002.

\section{7 - Dados complementares}

Os dados complementares demonstram que Veja não apresenta claramente a seu leitor de onde vem a informação que aparece estampada em suas páginas. Como é possível perceber ao se analisar as Tabelas 24, 25 e 26, além das Figuras 5, 6 e 7, na imensa maioria das vezes a publicação não identifica suas fontes de informação. Não é possível apontar de onde vieram as informações em $77 \%$ das unidades textuais no ano 2000, $86 \%$ em 2001, e novamente $77 \%$ em 2002. Como base de comparação, escolhemos realizar levantamento quantitativo das fontes fotográficas em Veja. Ele nos mostra que, ao contrário do que acontece com as fontes de informação, a revista escolhe dar crédito à imensa maioria das fotografias publicadas em suas páginas. Apenas 5\% das fotografias no ano 2000, 8\% em 2001, e novamente 5\% em 2002 não foram identificadas, como se vê nas Tabelas 28, 29 e 30. 
4.7.1 - Fontes utilizadas por Veja nas publicações pré-11 de setembro - Edições 1 666, 1 667, 1668 e 1669

Tabela 24: Distribuição das fontes de notícias para 2000.

\begin{tabular}{l|ccccc|cc}
\hline \multirow{2}{*}{\multicolumn{1}{c}{2000}} & \multicolumn{4}{c}{ Edição } & \multicolumn{2}{c}{ Total } \\
\cline { 2 - 6 } \multicolumn{1}{c}{} & $\mathbf{1 6 6 6}$ & $\mathbf{1 6 6 7}$ & $\mathbf{1 6 6 8}$ & $\mathbf{1 6 6 9}$ & Freq. & $\%$ \\
\hline Agência de notícias & 0 & 0 & 0 & 0 & 0 & 0 \\
Outros veículos & 2 & 1 & 2 & 1 & 6 & 4 \\
Fonte primária & 4 & 6 & 6 & 6 & 22 & 16 \\
Correspondente & 3 & 1 & 0 & 1 & 5 & 3 \\
Não identificada & 17 & 35 & 30 & 26 & 108 & 77 \\
\hline Total & 26 & 43 & 38 & 34 & 141 & 100 \\
\hline
\end{tabular}

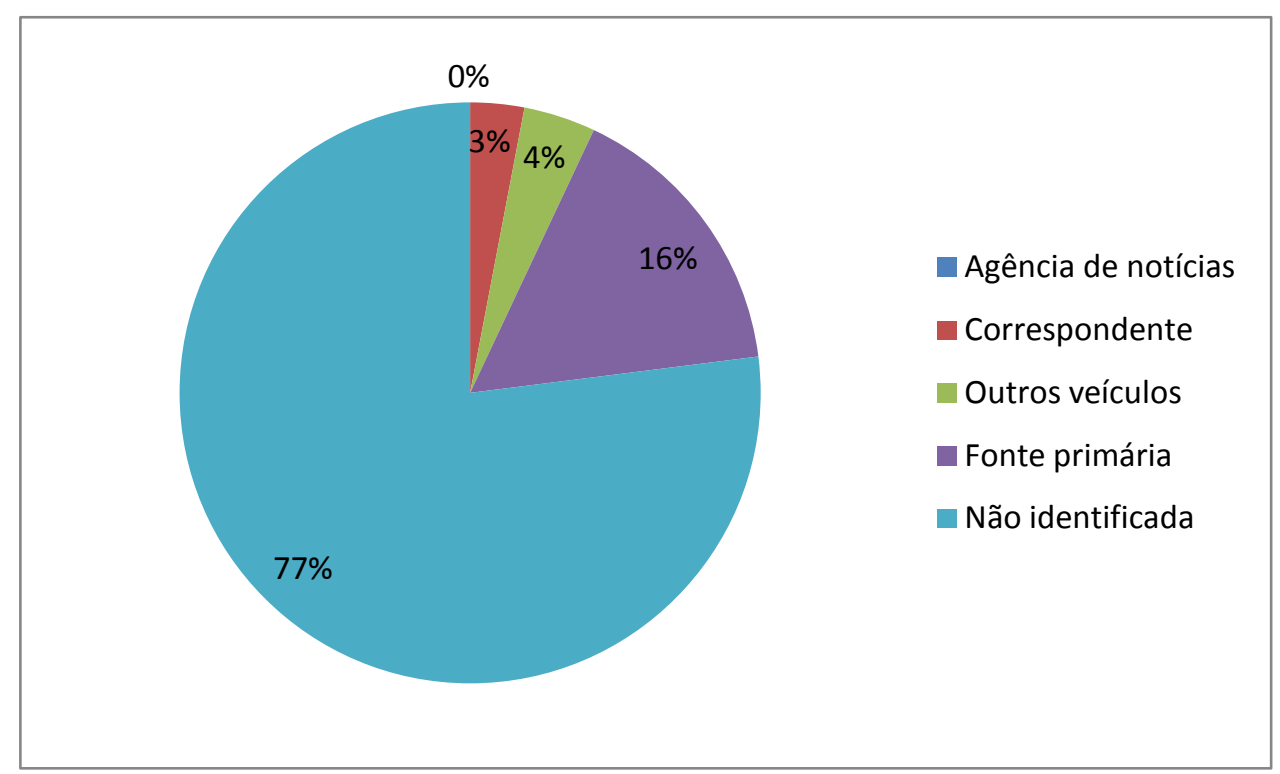

Figura 5: Gráfico para a distribuição das fontes de informação utilizadas por Veja para o ano 2000 
4.7.2 - Fontes utilizadas por Veja nas publicações imediatamente após 11 de setembro - Edições 1 718, 1719, 1720 e 1721

Tabela 25: Distribuição das fontes de notícias para 2001.

\begin{tabular}{l|cccc|cc}
\hline \multirow{2}{*}{\multicolumn{1}{c}{2001}} & \multicolumn{3}{c}{ Edição } & \multicolumn{2}{c}{ Total } \\
\cline { 2 - 6 } & $\mathbf{1 7 1 8}$ & $\mathbf{1 7 1 9}$ & $\mathbf{1 7 2 0}$ & $\mathbf{1 7 2 1}$ & Freq. & \% \\
\hline Agência de notícias & 0 & 0 & 0 & 0 & 0 & 0 \\
Outros veículos & 2 & 0 & 0 & 0 & 2 & 3 \\
Fonte primária & 3 & 0 & 0 & 2 & 5 & 6 \\
Correspondente & 1 & 1 & 1 & 1 & 4 & 5 \\
Não identificada & 16 & 18 & 18 & 17 & 69 & 86 \\
\hline Total & 22 & 19 & 19 & 20 & 80 & 100 \\
\hline
\end{tabular}

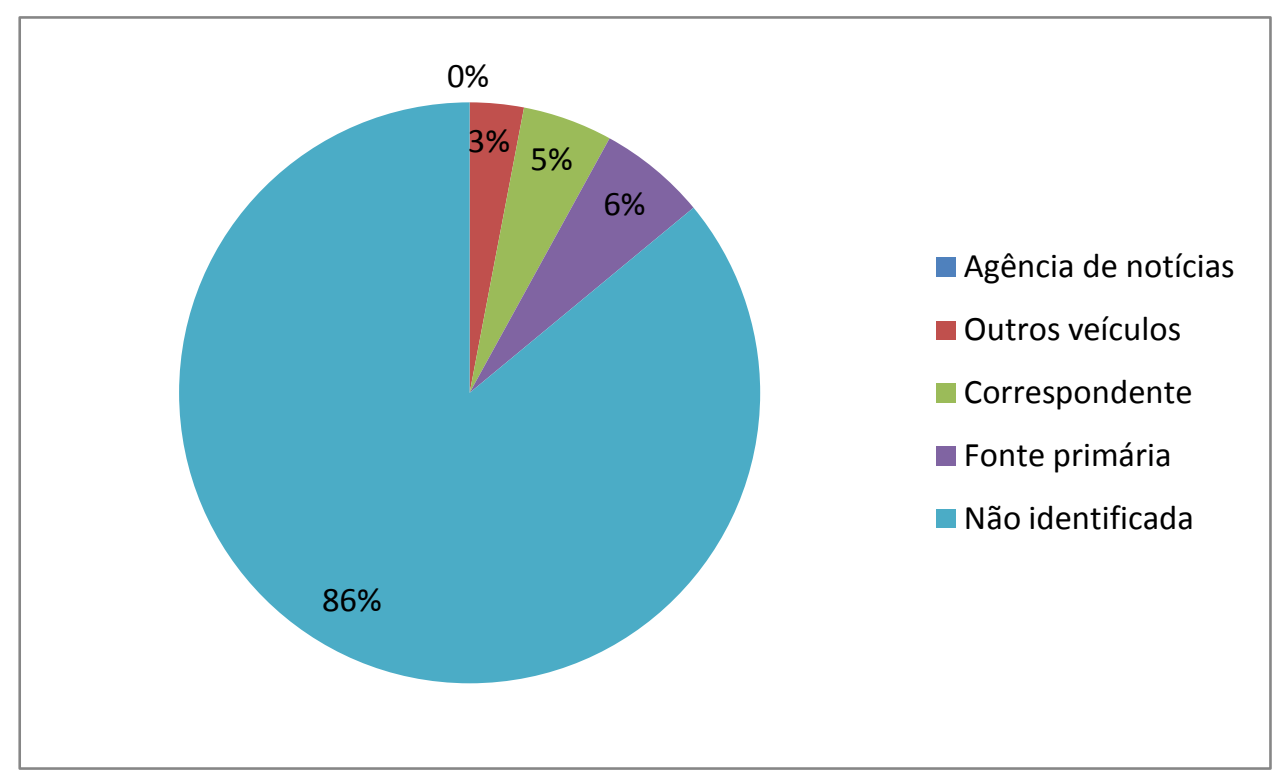

Figura 6: Gráfico para a distribuição das fontes de informação utilizadas por Veja para o ano 2001. 
4.7.3 - Fontes utilizadas por Veja nas publicações um ano após 11 de setembro - Edições 1 768, 1 769, 1 770, 1771

Tabela 26: Distribuição das fontes de notícias para 2002.

\begin{tabular}{l|ccccc|cc}
\hline \multirow{2}{*}{\multicolumn{1}{c}{2002}} & \multicolumn{4}{c}{ Edição } & \multicolumn{2}{c}{ Total } \\
\cline { 2 - 6 } & $\mathbf{1 7 6 8}$ & $\mathbf{1 7 6 9}$ & $\mathbf{1 7 7 0}$ & $\mathbf{1 7 7 1}$ & Freq. & $\%$ \\
\hline Agência de notícias & 0 & 0 & 0 & 0 & 0 & 0 \\
Outros veículos & 0 & 1 & 0 & 0 & 1 & 1 \\
Fonte primária & 1 & 1 & 4 & 2 & 8 & 10 \\
Correspondente & 2 & 4 & 2 & 2 & 10 & 12 \\
Não identificada & 16 & 15 & 15 & 17 & 63 & 77 \\
\hline Total & 19 & 21 & 21 & 21 & 82 & 100 \\
\hline
\end{tabular}

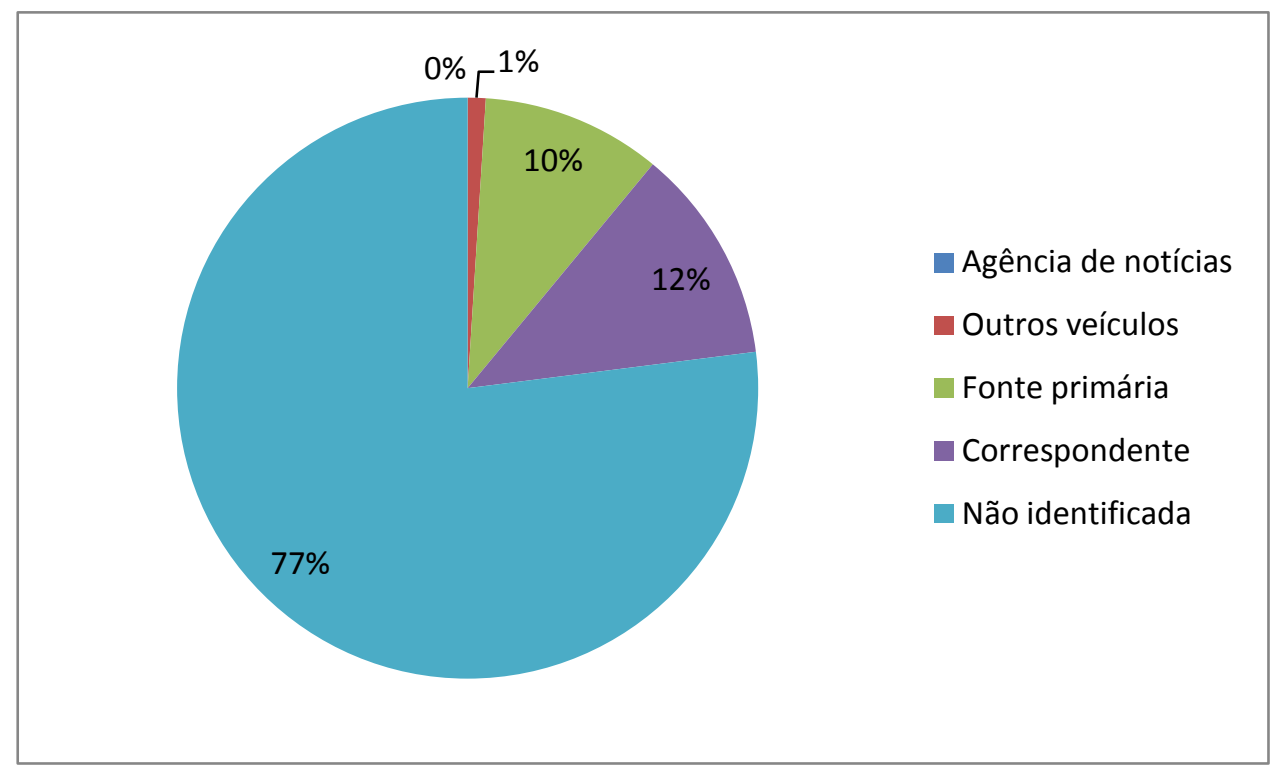

Figura 7: Gráfico para a distribuição das fontes de informação utilizadas por Veja para o ano 2002. 
Tabela 27: Distribuição das fontes de notícias para 2002.

\begin{tabular}{l|cccccc}
\hline & \multicolumn{2}{c}{2000} & \multicolumn{2}{c}{2001} & \multicolumn{2}{c}{2002} \\
\cline { 2 - 7 } & Freq. & \% & Freq. & \% & Freq. & \% \\
\hline Agência de notícias & 0 & 0 & 0 & 0 & 0 & 0 \\
Outros veículos & 6 & 4 & 2 & 3 & 1 & 1 \\
Fonte primária & 22 & 16 & 5 & 6 & 8 & 10 \\
Correspondente & 5 & 3 & 4 & 5 & 10 & 12 \\
Não identificada & 108 & 77 & 69 & 86 & 63 & 77 \\
\hline Total & 141 & 100 & 80 & 100 & 82 & 100 \\
\hline
\end{tabular}

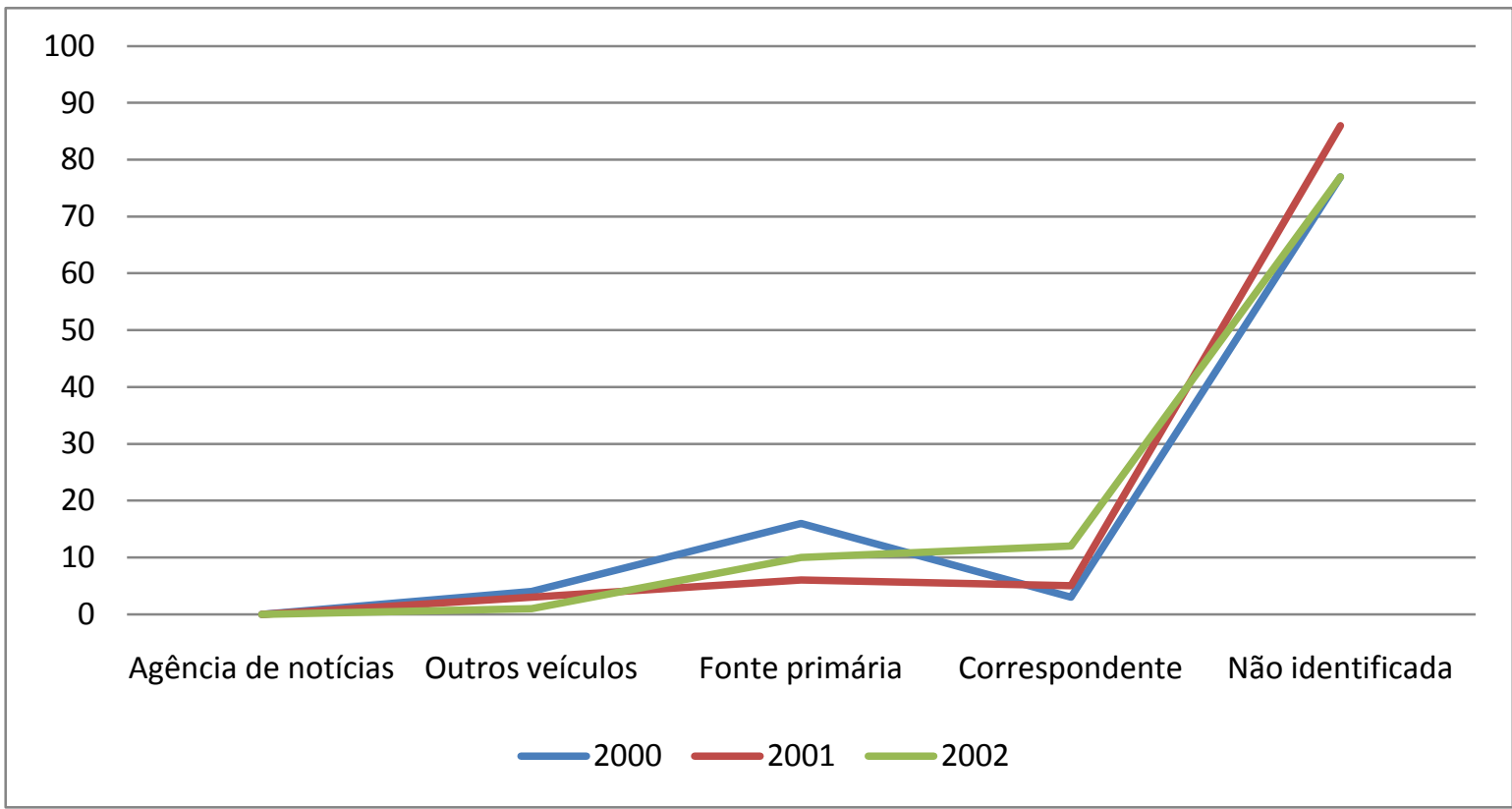

Figura 8: Gráfico para a distribuição das fontes de informação utilizadas por Veja para os três anos em estudo: 2000, 2001 e 2002. 
4.7.4 - Fontes fotográficas utilizadas por Veja nas publicações pré-11 de setembro - Edições 1 666, 1 667, 1668 e 1669

Tabela 28: Distribuição das unidades fotográficas de acordo com a fonte para 2000.

\begin{tabular}{l|cccc|cc}
\hline \multirow{2}{*}{2} & \multicolumn{4}{c}{ Edição } & \multicolumn{2}{c}{ Total } \\
\cline { 2 - 5 } & $\mathbf{1 6 6 6}$ & $\mathbf{1 6 6 7}$ & $\mathbf{1 6 6 8}$ & $\mathbf{1 6 6 9}$ & Freq. & \% \\
\hline AP & 5 & 8 & 8 & 11 & 32 & 16 \\
AFP & 3 & 7 & 3 & 3 & 16 & 8 \\
Reuters & 5 & 6 & 2 & 3 & 16 & 8 \\
Gamma & 3 & 6 & 9 & 5 & 23 & 12 \\
Sipa Press & 1 & 8 & 1 & 1 & 11 & 5 \\
Sygma & 1 & 5 & 3 & 4 & 13 & 7 \\
Não identificada & 3 & 1 & 3 & 3 & 10 & 5 \\
Outras & 12 & 23 & 15 & 26 & 76 & 39 \\
\hline Total & 33 & 64 & 44 & 56 & 197 & 100 \\
\hline
\end{tabular}

4.7.5 - Fontes fotográficas utilizadas por Veja nas publicações imediatamente após 11 de setembro - Edições 1 718, 1 719, 1720 e 1 721

Tabela 29: Distribuição das unidades fotográficas de acordo com a fonte para 2001.

\begin{tabular}{l|cccc|cc}
\hline \multirow{2}{*}{$\mathbf{2 0 0 1}$} & \multicolumn{3}{c}{ Edição } & \multicolumn{2}{c}{ Total } \\
\cline { 2 - 5 } \multicolumn{1}{c|}{} & $\mathbf{1 1 8}$ & $\mathbf{1 7 1 9}$ & $\mathbf{1 7 2 0}$ & $\mathbf{1 7 2 1}$ & Freq. & \% \\
\hline AP & 12 & 20 & 12 & 10 & 54 & 19 \\
AFP & 10 & 16 & 12 & 10 & 48 & 17 \\
Reuters & 6 & 22 & 5 & 11 & 44 & 16 \\
Gamma & 8 & 9 & 7 & 10 & 34 & 12 \\
Sipa Press & 10 & 2 & 4 & 4 & 20 & 7 \\
Sygma & 9 & 3 & 2 & 2 & 16 & 5 \\
Não identificada & 6 & 3 & 11 & 3 & 23 & 8 \\
Outras & 16 & 8 & 9 & 11 & 44 & 16 \\
\hline Total & 77 & 83 & 62 & 61 & 283 & 100 \\
\hline
\end{tabular}


4.7.6 - Fontes fotográficas utilizadas por Veja nas publicações um ano após 11 de setembro - Edições 1 768, 1 769, 1 770, 1771

Tabela 30: Distribuição das unidades fotográficas de acordo com a fonte para 2002.

\begin{tabular}{l|cccc|cc}
\hline \multirow{2}{*}{2} & \multicolumn{3}{c}{ Edição } & \multicolumn{2}{c}{ Total } \\
\cline { 2 - 5 } \multicolumn{1}{c}{} & $\mathbf{1 7 6 8}$ & $\mathbf{1 7 6 9}$ & $\mathbf{1 7 7 0}$ & $\mathbf{1 7 7 1}$ & Freq. & \% \\
\hline AP & 16 & 11 & 3 & 5 & 35 & 27 \\
AFP & 4 & 1 & 5 & 3 & 13 & 10 \\
Reuters & 6 & 4 & 1 & 4 & 15 & 12 \\
Gamma & 4 & 3 & 2 & 3 & 12 & 9 \\
Sipa Press & 0 & 1 & 1 & 0 & 2 & 2 \\
Sygma & 0 & 1 & 0 & 0 & 1 & 1 \\
Não identificada & 6 & 0 & 1 & 0 & 7 & 5 \\
Outras & 8 & 14 & 16 & 6 & 44 & 34 \\
\hline Total & 44 & 35 & 29 & 21 & 129 & 100 \\
\hline
\end{tabular}

Tabela 31: Distribuição das unidades fotográficas de acordo com a fonte para os três anos em estudo.

\begin{tabular}{l|cccccc}
\hline \multirow{2}{*}{} & \multicolumn{2}{c}{$\mathbf{2 0 0 0}$} & \multicolumn{2}{c}{$\mathbf{2 0 0 1}$} & \multicolumn{2}{c}{$\mathbf{2 0 0 2}$} \\
\cline { 2 - 7 } & Freq. & \% & Freq. & \% & Freq. & \% \\
\hline AP & 32 & 16 & 54 & 19 & 35 & 27 \\
AFP & 16 & 8 & 48 & 17 & 13 & 10 \\
Reuters & 16 & 8 & 44 & 16 & 15 & 12 \\
Gamma & 23 & 12 & 34 & 12 & 12 & 9 \\
Sipa Press & 11 & 5 & 20 & 7 & 2 & 2 \\
Sygma & 13 & 7 & 16 & 5 & 1 & 1 \\
Não identificada & 10 & 5 & 23 & 8 & 7 & 5 \\
Outras & 76 & 39 & 44 & 16 & 44 & 34 \\
\hline Total & 197 & 100 & 283 & 100 & 129 & 100 \\
\hline
\end{tabular}




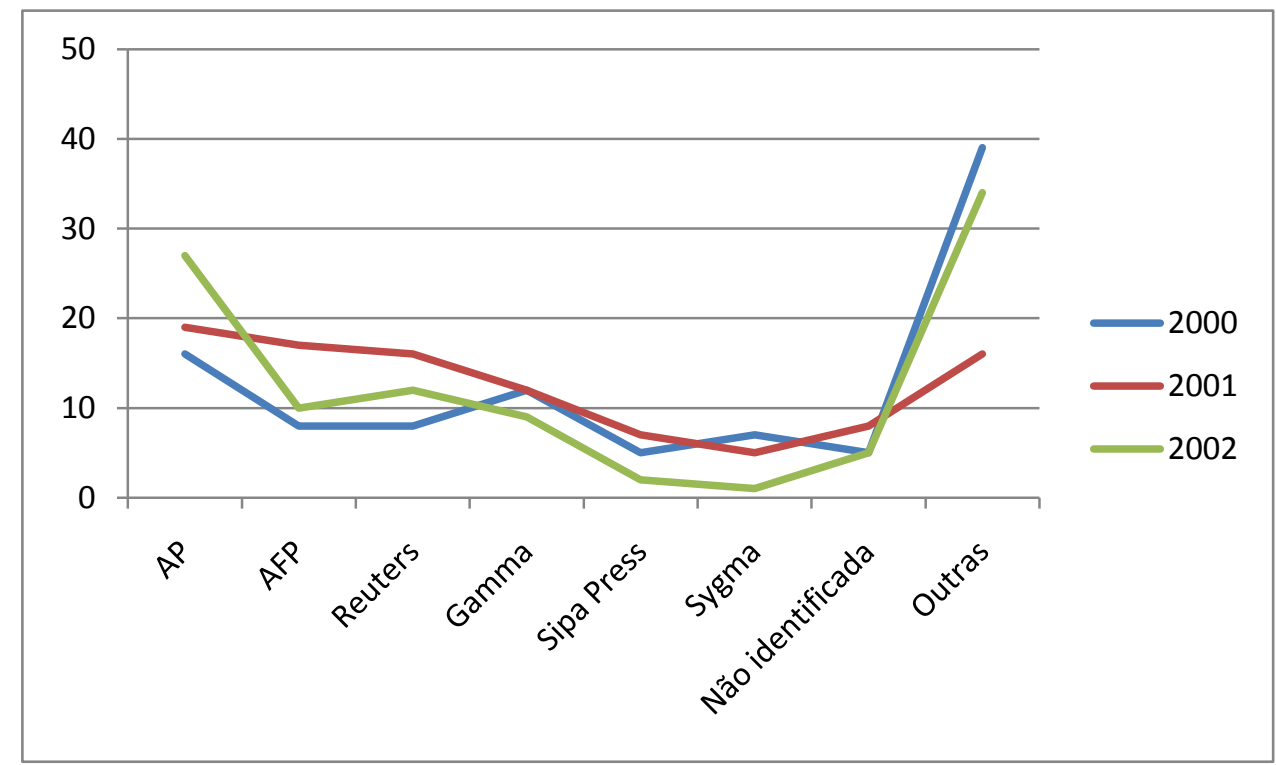

Figura 9: Gráfico para a distribuição percentual de unidades fotográficas utilizadas por Veja para os anos em estudo. 


\section{Considerações finais}

A dedicação à investigação cujos resultados aqui se apresentam se deu pela crença nas palavras de Said (2005, p. 10), destacadas no início deste trabalho, de que "uma das tarefas do intelectual reside no esforço em derrubar os estereótipos e as categorias redutoras que tanto limitam o pensamento humano e a comunicação". Com isso, buscamos realizar um mergulho na produção discursiva realizada pela mais destacada revista noticiosa do Brasil contemporâneo. Utilizando como referência teórica o Orientalismo, complementado pelo ferramental teórico-metodológico desenvolvido pela Teoria Social do Discurso, acreditamos ter alcançado dois objetivos. O primeiro, demonstrar estar correta a hipótese de que quando se trata da cobertura de assuntos relativos aos países de maioria muçulmana Veja reproduz, através de mecanismos textuais, o discurso hegemônico norte-americano, dando sustentação a uma visão naturalizada das posições americanas como legítimas, o que contribui para a construção de uma imagem negativa daqueles que professam sua fé no islamismo. E o segundo, apontar como isso se constrói, identificando como os enunciados e seu significado são organizados, mapeando as operações que os elaboram, determinando as condições de sua situação, e estabelecendo suas relações com outros enunciados.

Através da análise quantitativa, com a medição de dados de 1.123 textos publicados em três diferentes períodos, foi possível mapear a variação de interesse de Veja pelos países de maioria muçulmana, além de registrar em que momentos a publicação entende ser relevante mencionar ou não a religião islâmica em seus textos. Os dados mostram que Veja pouco se interessava por tais países um ano antes dos atentados de 11 de setembro, observando-os apenas perifericamente, enquanto o Islã mal era lembrado. O 11 de setembro leva a revista a dedicar boa parte de seus esforços ao tema, o que aumenta o número de vezes que os países muçulmanos são citados e faz com que o número de menções ao Islã suba em enorme medida, passando a aparecer na metade dos textos que tratam de temas internacionais. Ainda assim, Veja parece continuar a não achar importante tratar dos países islâmicos de maneira específica. Um ano depois, em 2002, os números voltam a se aproximar da situação pré-11 de setembro, ainda que a iminência da invasão ao Iraque faça com que o país apareça com frequência no noticiário, enquanto o Islã volta a números menores. A comparação dos dados dos três períodos mostra que os países de maioria islâmica merecem mais atenção 
de Veja nos momentos de conflito com os Estados Unidos e que o Islã é especialmente mencionado em momentos de violência.

A análise quantitativa dos dados complementares nos mostrou que Veja não identifica a imensa maioria de suas fontes de informação, ou seja, a publicação não informa aos seus leitores se as notícias internacionais que recebeu tratando de temas ligados aos países de maioria islâmica chegaram através de agências de notícias, jornais, emissoras de televisão ou rádio. O mesmo não acontece com as fontes fotográficas, quando a origem das imagens utilizadas para ilustrar as reportagens foram informadas sempre em porcentagens maiores que $94 \%$. O leitor de Veja sabe qual a agência que fotografou as imagens estampadas nas páginas da revista, mas não a fonte que produziu as informações nas mesmas páginas publicadas. Por fim, o mapeamento da origem dos entrevistados por Veja somado ao levantamento da maneira como afirmações e opiniões foram registradas nas reportagens nos mostrou primeiro estar completamente apartado da realidade o slogan Quem lê Veja entende os dois lados, utilizado pela revista entre os anos de 2004 e 2009, uma vez que os membros dos países de maioria muçulmana são os que menos espaço de manifestação tiveram nas páginas da revista. Acadêmicos, intelectuais, especialistas, jornalistas e políticos norte-americanos e europeus, além de brasileiros, em menor medida, são as vozes que se revezam nos textos quando o assunto é o Islã ou os países de maioria muçulmana. O número total de manifestações de tais atores só é menor que outros dois tipos de manifestações: as pressuposições existenciais - ou seja, quando Veja expõe certo dado como fato indiscutível, sem qualquer possibilidade de contraditório, camuflando diferenças de poder, indicando a normalização e a aceitação, sem expor ao leitor de onde vem tal afirmação, uma vez que ela passa a representar a voz do autor do texto - e as afirmações avaliativas e presunções valorativas, relacionadas à maneira como os autores comprometem-se com 0 que é considerado bom ou ruim, desejável ou indesejável, sendo fator substancial de como se identificam com a questão abordada.

As pressuposições, avaliações e presunções foram não apenas tabuladas quantitativamente, mas também contempladas em análise qualitativa, o que nos permitiu avançar na análise sobre a maneira como é construído o discurso de Veja sobre muçulmanos. Enquanto o levantamento quantitativo da intertextualidade nos mostrou que nas quatro unidades textuais analisadas no período anterior ao11 de setembro apenas um membro de país de maioria muçulmana ganhou voz, a análise qualitativa nos permitiu observar que o discurso, direto ou indireto, que de acordo com a ADC é a 
opção mais dialógica, representando abertura para a diferença, foi substituído por pressuposições existenciais, afirmações avaliativas e presunções valorativas que generalizaram acusações calcadas tão-somente no senso comum, o que está de acordo com a atitude Orientalista, segundo Said (1990, p. 80):

Ela compartilha com a magia e com a mitologia o caráter autocontido e autoreforçado de um sistema fechado, no qual os objetos são o que são porque são o que são, agora e sempre, por razões ontológicas que nenhum material pode remover ou alterar.

A avaliação dos posicionamentos de Veja no período anterior ao 11 de setembro revelou que a revista não aderiu à repetição do discurso hegemônico norte-americano apenas no momento em que o presidente George W. Bush cobrou um posicionamento dos que estão "conosco" ou com "eles". Como demonstrado neste trabalho, um ano antes dos ataques contra os Estados Unidos já era possível encontrar nas páginas da revista a manifestação do que Said chama de "um universo de discurso representativo que é peculiar à discussão e ao entendimento do Islã e do Oriente" (SAID, 1990). A construção e manutenção de uma identidade negativa dos que professam sua fé na religão islâmica já estava em pleno vigor nas páginas de Veja.

E se assim era no ano 2000, na esteira dos ataques suicidas de setembro de 2001 tais características foram fortemente acentuadas, passando a cobertura do semanário brasileiro a juntar às figuras de linguagem associadas ao Oriente - desrespeitosas, declarativas e auto-evidentes - uma construção discursiva voltada ao convencimento da necessidade de uma ação militar impiedosa e à legitimação do ataque que se desenhava, primeiro contra o Afeganistão e depois, como se sabe, contra o Iraque. Para tanto, o discurso direto e indireto foi permitido a apenas dois moradores de países de maioria muçulmana, além de uma declaração do governo do Paquistão, enquanto trinta e um norte-americanos, europeus e brasileiros tiveram suas declarações e opiniões divulgadas por Veja. Entre eles, apenas quatro críticos ao posicionamento norte-americano e, ainda assim, acompanhados dos adjetivos "lentos" e "preguiçosos". As pressuposições, afirmações e presunções foram utilizadas na construção de um discurso em defesa de uma resposta militar contra o Afeganistão e sua infraestrutura, ainda que o país não fosse o responsável pelos atentados, mas sim o local onde, acreditava-se, estivessem escondidos os responsáveis pelos ataques. Ou seja, a revista utilizou de operações discursivas para, primeiro, construir um consenso em torno da necessidade e inevitabilidade do uso da força contra o Afeganistão e, depois, legitimar tal disposição 
através da manipulação de dados históricos, apelo a fatores intangíveis, como o que chamou de "dever da civilização ocidental", e desqualificação dos que se posicionaram contra os planos norte-americanos. Tudo isso complementado pelo desfiar de um rosário de adjetivos usados para qualificar moradores de países de maioria muçulmana, como “criminosos", “demagogos", "loucos", “arrasados", “atrasados”, "miseráveis", "primitivos", "ignorantes", "serpentes" e "corvos".

A análise qualitativa das unidades textuais publicadas um ano depois do 11 de setembro mostrou que se o momento mais agudo das declarações de Veja se concentrou nos dias seguintes aos atentados, o distanciamento dos eventos não alterou a posição da revista como canal para reprodução do discurso norte-americano e não suavizou a desconfiança da revista em relação aos muçulmanos. Da mesma maneira, não alterou na publicação a disposição para manipular e distorcer informações, assim como não despertou na publicação a disposição para buscar opiniões que contrariem as de caráter oficial, sempre presentes em suas páginas. O fato novo foi o surgimento da questão econômica, através do petróleo. Como Said havia identificado, ganha evidência o pensamento de que o Ocidente está sendo confrontado com a possibilidade de não mais poder assegurar uma ordenada distribuição do "produto mundial". O controle parece escapar das mãos dos países tradicionalmente geradores da ordem econômica para estar perigosamente nas mãos dos países do Oriente Médio, o que leva à conclusão de que "if these new nations are not creators and generators of order, they can only be disruptors of it. And [...] they disrupt because all they are and can be as a group is inversely equal and opposite to "us"” ${ }^{104}$ (SAID, 1997, p. 38). A principal questão é o petróleo. A oferta da commoditie para suprir nossa demanda. Para que a estabilidade do sistema capitalista não seja atingida, Veja utiliza o discurso disciplinador, que prega que a ordem deve ser mantida, não em nome dos iraquianos, como em alguns momentos pode-se vir a pensar, mas em nome da economia mundial. E se os ganhos financeiros exigem, ou se os Estados Unidos exigem para isso a invasão do Iraque e a derrubada de Saddam, que assim o seja, ainda que ao custo de milhares de vidas inevitavelmente perdidas durante os ataques que viriam em poucos meses.

Ao final das análises quantitativa e qualitativa nos três períodos, utilizando-nos das práticas teórica e metodológica da ADC para observar as unidades textuais de Veja - não meramente como evento linguístico, mas como práticas sociais em sua relação

\footnotetext{
104 “se essas novas nações não são criadoras e geradoras da ordem, elas só podem ser perturbadoras dela. E [...] perturbam porque elas todas são e podem ser como grupo é inversamente igual e oposto a 'nós"'
} 
dialética que tanto constitui quanto é constituída socialmente pelo sistema de crenças -, foi possível constatar a utilização de práticas orientalistas, através da internalização e reprodução do discurso norte-americano sobre os países de maioria muçulmana, resultando em operações que trabalham para obtenção do consenso em torno de uma posição hegemônica que busca a universalização, mas opera dividindo a realidade humana entre "nós", o Ocidente, e "eles", os orientais, muçulmanos.

Tal fato encaminha a conclusão deste trabalho para aquela que é, segundo Edward Said (2007, p. 80), a principal questão intelectual colocada pelo Orientalismo: "Será que podemos dividir a realidade humana, como ela na verdade parece estar dividida, em culturas, histórias, tradições, sociedades e até raças claramente diferentes, e sobreviver humanamente às consequências?”. 


\section{Referências bibliográficas}

ALDÉ, Alessandra. Mídia e Guerra: enquadramentos do Iraque. Trabalho apresentado ao XIII Encontro Anual da Associação Nacional dos Programas de Pós-Graduação em Comunicação (COMPÓS), São Bernardo do Campo, 2004. Disponível em: <http://egroups.unb.br/fac/comunicacaoepolitica/alessandra2004.pdf>.

ALMEIDA, Maria Fernanda Lopes. Veja sob censura: 1968-1976. São Paulo: Jaboticaba, 2009.

ALTHUSSER, Louis. Aparelhos ideológicos de Estado: nota sobre os aparelhos ideológicos de Estado. Rio de Janeiro: Edições Graal, 1985.

ARAÚJO NETO, Antônio Martins de. O Jornalismo na Guerra do Iraque: a relação entre jornalistas e militares na era dos repórteres embutidos. Trabalho apresentado ao NP 02 - Jornalismo, do V Encontro dos Núcleos de Pesquisa da Intercom, 2005. In: http://www.intercom.org.br/papers/nacionais/2005/resumos/R1403-1.pdf ARENDT, Hannah. Eichmann em Jerusalém. São Paulo: Companhia das Letras, 1999. Essays in understanding: 1930-1954. Edited by Jeromy Kohn. New York: Shocken Books, 2005.

BAKHTIN, Mikhail (V.N. Volochínov). Marxismo e filosofia da linguagem: problemas fundamentais do método sociológico na ciência da linguagem. São Paulo: Editora Hucitec, 1992.

Questões de literatura e de estética: a teoria do romance. São Paulo: Unesp, 1993.

Problemas da poética de Dostoiévski. Rio de Janeiro: Forense Universitária, 1997.

Estética da criação verbal. São Paulo: Martins Fontes, 2003.

; MEDVEDEV, Pavel. El Método Formal en los Estudios Literarios. Madri:

Alianza Editorial, 1994.

BLOMMAERT, Jan; BULCAEN, Chris. Cristical Discourse Analysis. In: Annual Review of Anthropology, v. 29: 447-466, outubro de 2000.

BORDIEU, Pierre; CHAMBOREDON, Jean-Claude; PASSERON, Jean-Claude. A profissão de sociólogo: preliminares epistemológicas. Petrópolis: Vozes, 1999. 
BRANDÃO, Helena Nagamine. Texto, gênero do discurso e ensino. In: (Org.).

Gêneros do discurso na escola. São Paulo: Cortez, 2000.

CARVALHO, Anabela. O Iraque nas televisões européias: representações da Segunda Guerra do Golfo. II CONGRESSO IBÉRICO DE CIÊNCIAS DA COMUNICAÇÃO, Universidade da Beira Interior, Covilhã, abril de 2004. Disponível em: <http://repositorium.sdum.uminho.pt/handle/1822/1797>.

CASTRO, Isabelle C. S. Orientalismo na imprensa brasileira: a representação de árabes e muçulmanos nos jornais Folha de S.Paulo e O Estado de S._Paulo antes e depois de 11 de setembro de 2001. 2007. Dissertação de Mestrado no Programa de Pós Graduação em Língua, Literatura e Cultura Árabe da FFLCH da USP, São Paulo, 2007. CHARAUDEAU, Patrick. Discurso das mídias. São Paulo: Contexto, 2007.

; MAINGUENEAU, Dominique. Dicionário de análise do discurso. São Paulo: Contexto, 2008.

CHOMSKT, Noam. 11 de setembro. Rio de Janeiro: Bertrand Brasil, 2002.

CHOULIARAKI, Lilie; FAIRCLOUGH, Norman. Discourse in late modernity: rething critical discourse analysis. Edinburgh: Edinburgh University Press, 1999.

DANIEL, Norman. Islam and the West: the making of an image. Oxford: Oneworld, 2003.

DEFLEUR, Melvin L.; BALL-ROKEACH, Sandra. Teorias da comunicação de massa.

Rio de Janeiro: Jorge Zahar, 1993.

DELEUZE, Gilles; GUATTARI, Felix. Mil Platôs. Capitalismo e Esquizofrenia. v. 2. Rio de Janeiro: Editora 34, 1995.

DIJK, Teun A. van. Discurso e poder. São Paulo: Contexto, 2008.

EAGLETON, Terry. Ideologia. Uma introdução. São Paulo: Editora da Universidade Estadual Paulista; Editora Boitempo, 1997.

ELIAS, Norbert; SCOTSON, John L. Os estabelecidos e os outsiders: sociologia das relações de poder a partir de uma pequena comunidade. Rio de Janeiro: Jorge Zahar Ed., 2000.

FAIRCLOUGH, Norman. Media Discourse. London: Hodder Arnold, 1995.

Discurso e mudança social. Brasília: Editora Universidade de Brasília, 2001 [1992].

Analysing discourse: textual analysis for social research. New York: Routledge, 2003.

FARAH, Paulo Daniel. O Islã. São Paulo: Publifolha, 2001. 
FOUCAULT, Michel. Microfísica do poder. Rio de Janeiro: Edições Graal, 1979.

A ordem do discurso. Aula inaugural no Collège de France, pronunciada em 2 de dezembro de 1970. São Paulo: Loyola, 1996.

Vigiar e Punir: nascimento da prisão. Rio de Janeiro: Vozes, 2009.

A arqueologia do saber. Rio de Janeiro: Forense Universitária, 2010.

FREUD, Sigmund. O Mal-Estar na Civilização. Lisboa: Relógio D’Água Editores, 2008.

FRY, Karin A. Compreender Hannah Arendt. Petrópolis: Vozes, 2010.

GANS, Herbert J. Deciding what's news. New York: Pantheon Books, 1979.

GAZZOTTI, Juliana. Imprensa e ditatura: a revista Veja e os governos militares (196885). 1998. Dissertação (Mestrado em Ciências Sociais) - Universidade Federal de São Carlos, São Carlos, 1998.

GEERTZ, Clifford. A interpretação das culturas. Rio de Janeiro: LTC, 1989.

GIDDENS, Anthony. As consequências da modernidade. São Paulo: Editora Unesp, 1991.

Modernidade e Identidade. Rio de Janeiro: Jorge Zahar, 2002.

GOFFMAN, Erving. Estigma: notas sobre a manipulação da identidade deteriorada. Rio de Janeiro: LTC, 2008.

GOMES, Mayra Rodrigues. Poder no Jornalismo: Discorrer, Disciplinar, Controlar. São Paulo: Hacer Editores; Edusp, 2003.

- Comunicação e identificação: ressonâncias no jornalismo. Cotia: Ateliê Editorial, 2008.

GRAMSCI, Antonio. Selections from prison notebooks. London: Lawrence and Wishart, 1971.

GRILLO, Sheila V. de C. Esfera e Campo. In: BRAIT, Beth. Bakhtin: outros conceitoschave. São Paulo: Contexto, 2006.

HALL, Stuart. A identidade cultural na pós-modernidade. Rio de Janeiro: DP\&A, 1999. - Da diáspora: identidades e mediações culturais. Belo Horizonte: UFMG/Unesco, 2003.

Quem precisa de identidade? In: SILVA, Tomaz Tadeu da (Org.). Identidade e diferença: a perspectiva dos estudos culturais. Petrópolis: Vozes, 2008.

HALLIDAY, M.A.K. Introduction to functional grammar. London: Edgard Arnold, 1985

HARDT, Michael; NEGRI, Antonio. Império. Rio de Janeiro: Record, 2005. 
HARVEY, David. A condição pós-moderna. São Paulo: Loyola, 1992.

HERSCOVITZ, Heloiza G. Análise de conteúdo em jornalismo. In: LAGO, Claudia; BENETTI, Marcia. Metodologia de pesquisa em jornalismo. Petrópolis: Vozes, 2007.

HESTER, Al. As agências noticiosas ocidentais: problemas e oportunidades nas notícias internacionais. In: MATTA, Fernando Reys (Org.). A informação na nova ordem internacional. Rio de Janeiro: Paz e Terra, 1980.

HOURANI, Albert. Uma história dos povos árabes. São Paulo: Companhia das Letras, 2006.

HUNTINGTON, Samuel P. The Clash of Civilizations? In: Foreign Affairs, Summer 1993. Disponível em: <http://www.foreignaffairs.com/articles/48950/samuel-phuntington/the-clash-of-civilizations>. O choque de civilizações e a recomposição da ordem mundial. Rio de Janeiro: Objetiva, 1997.

IANNI, Octavio. Globalização: novo paradigma das ciências sociais. In: Estudos Avançados, v. 8, n. 21. São Paulo: USP/IEA, 1994.

KEHL, Maria Rita. As máquinas falantes. In: NOVAES, Adauto (Org.). O homemmáquina: a ciência manipula o corpo. São Paulo: Companhia das Letras, 2003.

LACAN, Jacques. O estádio do espelho como formador da função do eu. In: Escritos. Rio de Janeiro: Jorge Zahar, 1998.

LOPES, Maria Immacolata-Vassallo de. Pesquisa em comunicação. São Paulo: Loyola, 2005 .

LYOTARD, Jean-François. A condição pós-moderna. Lisboa, Gradiva, 1989

MAGALHÃES, Izabel. Introdução. A Análise de Discurso Crítica. In: D.E.L.T.A., v. 21, nº especial, São Paulo, 2005.

MATTA, Fernando Reyes. A evolução histórica das agências transnacionais de notícias no sentido da dominação. In: (Org.). A informação na nova ordem internacional. Rio de Janeiro: Paz e Terra, 1980.

MAZZARA, Bruno M. Estereótipos y prejuícios. Madri: Acento Editorial, 1999.

MELO, José Marques de. Jornalismo opinativo: gêneros opinativos no jornalismo brasileiro. Campos do Jordão: Mantiqueira, 2003.

MONTENEGRO, Silvia M. Discursos e contradiscursos: o olhar da mídia sobre o Islã no Brasil. In: Mana: Estudo de Antropologia Social, v. 8, Rio de Janeiro, Universidade Federal do Rio de Janeiro, 2002. 
MIRA, Maria Celeste. O leitor e a banca de revistas: o caso da Editora Abril.1997. Tese (Doutorado em Sociologia apresentada ao Departamento de Sociologia do Instituto de Filosofia e Ciências Humanas da Unicamp, Campinas, 1997. Disponível em: <http://www.bibliotecadigital.unicamp.br/document/?code=000122361>.

MORIN, Edgar. A cabeça bem-feita: repensar a reforma, reformar o pensamento. Rio de Janeiro: Bertrand Brasil, 2003. Introdução ao pensamento complexo. Lisboa: Instituto Piaget, 2002.

POOLE, Elizabeth. Reporting Islam: Media Representations of British Muslims. London: I.B Tauris Publishers, 2002.

RAJAGOPALAN, Kanavillil. Por uma linguistica crítica: linguagem, identidade e a questão ética. São Paulo: Parábola Editorial, 2003.

RAMALHO, Viviane. O discuso da imprensa brasileira sobre a invasão anglosaxônica ao Iraque. 2005. Dissertação (Pós-graduação em Lingüística)- Depto. de Linguística, Línguas Clássicas e Vernácula, Instituto de Letras, Universidade de Brasília, $\quad 2005 . \quad$ Brasília, em: $<$ http//bdtd.bce.unb.br/tedesimplificado/tde_arquivos/56/TDE-2007-09-20T150821Z1784/Publico/Dissert_Viviane\%20Cristina\%20Vieirapdf $>$.

RESENDE, Viviane de Melo e RAMALHO, Viviane. Análise do discurso crítica. São Paulo: Contexto, 2006.

ROSS, Lee. The intuitive phychologist and his shortcomings: distortions in the attribution process. In: Advances in experimental social psychology, v. 10. New York: Academic Press, 1977

SADER, Emir (Org.). Gramsci: poder, política e partido. São Paulo: Expressão Popular, 2005.

SAID, Edward W. Orientalismo: o Oriente como invenção do Ocidente. São Paulo: Companhia das Letras, 1990.

Covering Islam: how the media and the experts determine how we see the rest of the world. London: Vintage Books, 1997.

The Clash of Ignorance. In: The Nation, 4 de outubro de 2001. Disponível em: $<$ http://www.thenation.com/print/article/clash-ignorance>.

Reflexões sobre o exílio e outros ensaios. São Paulo: Companhia das Letras, 2003.

Fora do lugar: memórias. São Paulo: Companhia das Letras, 2004.

Cultura e Imperialismo. São Paulo: Companhia das Letras, 2005. 
Orientalismo: o Oriente como invenção do Ocidente. São Paulo: Companhia das Letras, 2007.

Humanismo e crítica democrática. São Paulo: Companhia das Letras, 2007a. . Representações do intelectual: as Conferências Reith de 1933. São Paulo:

Companhia das Letras, 2005.

SILVA, Carlos Eduardo Lins da. O adiantado da hora: a influência americana sobre o jornalismo brasileira. São Paulo: Summus, 1991.

SILVA, Tomaz Tadeu da. A produção social da identidade e da diferença. In: SILVA, Tomaz Tadeu da (Org.). Identidade e diferença: a perspectiva dos estudos culturais. Petrópolis: Vozes, 2008.

SOARES, Rosana de Lima. Margens da comunicação: discurso e mídias. São Paulo: Annablume, 2009.

THIBODEAU, Paul H.; BORODITSKY, Lera. Metaphors we think with: the role of metaphor in reasoning. In: PLoS ONE 6(2): e16782. doi:10.1371/journal.

pone.0016782, 2011. Disponível em:

<http://www.plosone.org/article/info:doi\%2F10.1371\%2Fjournal.pone.0016782>.

THOMPSON, John B. A mídia e a modernidade: uma teoria social da mídia. Petrópolis: Vozes, 2008.

Ideologia e cultura moderna: teoria social crítica na era dos meios de comunicação de massa. Petrópolis: Vozes, 2009.

TODOROV, Tzvetan. Mikhaïl Bakhtine - Le principe dialogique - suivi de Écrits du Cercle de Bakhtine. Paris: Éditions du Seuil, 1981.

. A Conquista da América: a questão do outro. São Paulo: Martins Fontes, 2003.

WOLF, Mauro. Teoria das comunicações de massa. São Paulo: Martins Fontes, 2005.

WOODWARD, Kathryn. Identidade e diferença: uma introdução teórica e conceitual. In: SILVA, Tomaz Tadeu da (Org.). Identidade e diferença: a perspectiva dos estudos culturais. Petrópolis: Vozes, 2008. 
